UNIVERSIDADE DE SÃO PAULO

FACULDADE DE FILOSOFIA, LETRAS E CIÊNCIAS HUMANAS DEPARTAMENTO DE HISTÓRIA PROGRAMA DE PÓS-GRADUAÇÃO EM HISTÓRIA SOCIAL

\author{
DEBORA GOMES PEREIRA AMARAL
}

\begin{abstract}
A ICONOCLASTIA NAS PINTURAS DA CAPELA DO ANTIGO CONVENTO DO CRISTO DA PACIÊNCIA DE MADRI (SÉCULO XVII)
\end{abstract}


UNIVERSIDADE DE SÃO PAULO

FACULDADE DE FILOSOFIA, LETRAS E CIÊNCIAS HUMANAS

DEPARTAMENTO DE HISTÓRIA

PROGRAMA DE PÓS-GRADUAÇÃO EM HISTÓRIA SOCIAL

\title{
A ICONOCLASTIA NAS PINTURAS DA CAPELA DO ANTIGO CONVENTO DO CRISTO DA PACIÊNCIA DE MADRI (SÉCULO XVII)
}

\begin{abstract}
Debora Gomes Pereira Amaral
Dissertação apresentada ao Programa de Pós-graduação em História Social do Departamento de História da Faculdade de Filosofia, Letras e Ciências Humanas da Universidade de São Paulo para a obtenção do título de Mestre.

Orientadora: Profa. Dra. Maria Cristina Correia Leandro Pereira
\end{abstract}

São Paulo

2016 
Autorizo a reprodução e divulgação total ou parcial deste trabalho, por qualquer meio convencional ou eletrônico, para fins de estudo e pesquisa, desde que citada a fonte.

Catalogação na Publicação

Serviço de Biblioteca e Documentação

Faculdade de Filosofia, Letras e Ciências Humanas da Universidade de São Paulo

A485i

Amaral, Debora Gomes Pereira

A ICONOCLASTIA NAS PINTURAS DA CAPELA DO ANTIGO CONVENTO DO CRISTO DA PACIÊNCIA DE MADRI (SÉCULO

XVII) / Debora Gomes Pereira Amaral ; orientadora Maria Cristina Correia Leandro Pereira. - São Paulo, 2016.

$201 \mathrm{f}$.

Dissertação (Mestrado) - Faculdade de Filosofia, Letras e Ciências Humanas da Universidade de São Paulo. Departamento de História. Área de concentração: História Social.

1. HISTÓRIA DA ESPANHA. 2. BARROCO. 3. HISTÓRIA DA PINTURA. 4. INQUISIÇÃO . I. Pereira, Maria Cristina Correia Leandro, orient. II. Título. 


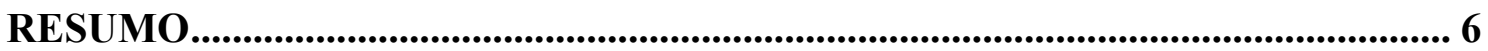

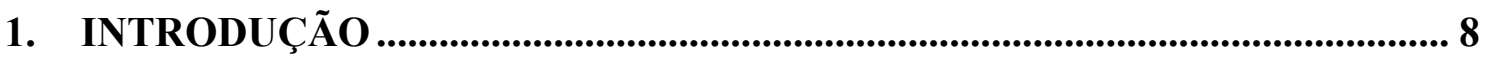

2. AS IMAGENS RELIGIOSAS NA ESPANHA DO SÉCULO XVII: USOS E

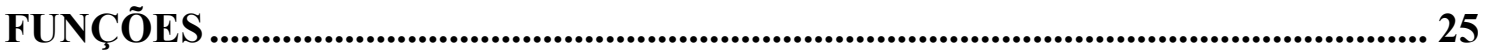

2.1. Concílio de Trento, Sínodos e Tratados: as imagens sagradas após a Reforma Protestante......28 Sobre a invocação, a veneração e as relíquias dos santos, e sobre as imagens sagradas, de 1563 .......30

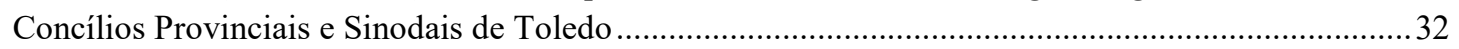

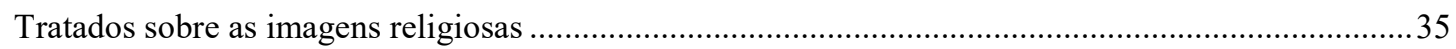

2.2. As imagens cristãs na Península Ibérica no final da Idade Média e início da Moderna ..............39

Cristocentrismo: o culto à Cruz, ao sofrimento e ao sangue de Cristo....................................................... 44

2.3. Política das imagens e a Inquisição …………………......................................................................48

As imagens religiosas para os marranos .........................................................................49

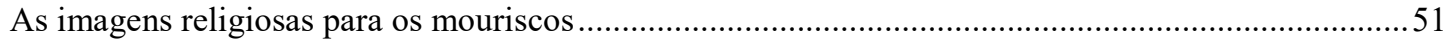

A Inquisição e as imagens ............................................................................................53

Os processos do Santo Ofício como fonte historiográfica ..................................................5

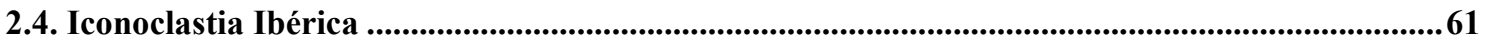

3. UM PROJETO VISUAL EXPIATÓRIO: O CONVENTO E A CAPELA DO SANTÍSSIMO CRISTO DA PACIÊNCIA DE MADRI........................................... 65

3.1. A igreja do Real Convento da Paciência de Cristo ...............................................................................65

3.2. As imagens da Capela do Santíssimo Cristo da Paciência de Madri ................................................75

Narrativas textuais do milagre do Santissimo Cristo de la Paciencia de Madrid ......................................75

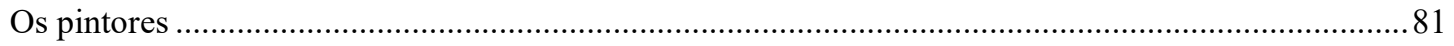

4. OS AGRESSORES DO CRISTO DA PACIÊNCIA ..........................................85

4.1. A política econômica do Conde Duque de Olivares..................................................................................85

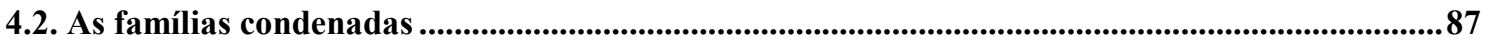

4.3. Andresillo: poca razón y capacidad, como tontillo ..................................................................................90

\section{AS PINTURAS DA CAPELA DA PACIÊNCIA: OS HEREGES ANTE O}

CRUCIFIXO MILAGROSO....................................................................................... 93

5.1. Descrição dos elementos formais que compõem as pinturas ..............................................................93 
5.2. A figuração dos hereges ........................................................................................................................105

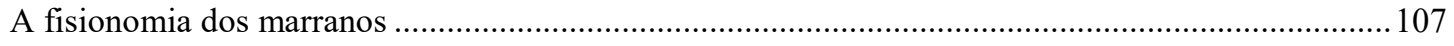

Imagem da infâmia: translatio, memória e perpetuação da lenda...................................................... 129

5.3. A imagem do crucifixo milagroso..............................................................................................140

A meta-imagem: a representação da imagem sagrada ............................................................... 143

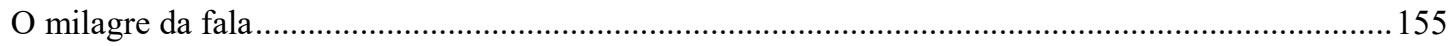

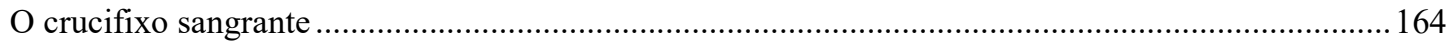

A dor e o sofrimento de uma imagem .................................................................................... 179

6. CONSIDERAÇÕES FINAIS .................................................................................. 181

7. REFERÊNCIAS ….......................................................................................... 184

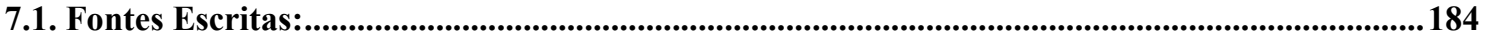

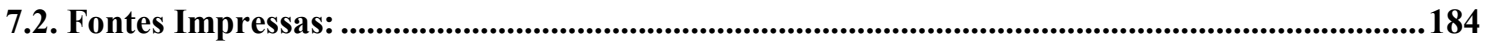

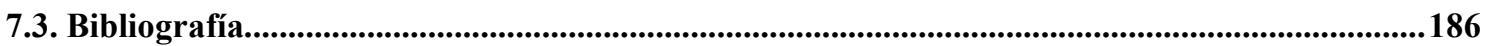

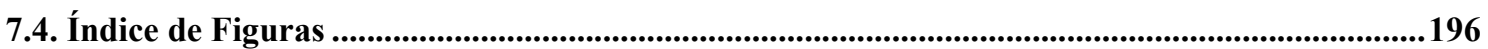




\section{Agradecimemtos}

Agradeço a José Renato das Graças Amaral por seu amor, apoio incondicional e incentivo durante nossa jornada de mais de vinte anos, e especialmente pela paciência e ajuda durante o processo de pesquisa.

À Profa. Dra. Maria Cristina Correia Leandro Pereira, que com sua generosidade me acolheu. À sua dedicada orientação, compartilhando de sua sabedoria, o que foi fundamental tanto para a realização desta pesquisa como para o meu crescimento acadêmico.

Às professoras da banca avaliadora, Profa. Dra. Rita Bredariolli e Profa. Dra. Maria Lêda Oliveira Alves da Silva, pelas atenciosas sugestões e críticas no exame de qualificação.

Aos meus pais, Helio Pereira e Maria Helena Gomes Pereira, pelo amor, por terem me proporcionado educação e me ensinado o quão importante e valoroso é o conhecimento. Aos meus irmãos Daniel, Yara e Angélica, pelo torcida e pelos inúmeros momentos de alegria.

A Marcia Augusto das Graças Amaral, pois sem sua amizade e ajuda eu não poderia ter realizado esta pesquisa.

Ao Lathimm (Laboratório de Teoria e História da Imagem e da Música Medievais), com as ricas discussões acadêmicas.

Aos queridos amigos do Lathimm, Muriel, Doglas, Selene, Aline, Gesner, Fabiana, Mariana, Renan e Raíssa, que sempre estiveram presentes me ajudando nos momentos mais anguntiantes.

Ao Museu do Prado, que permitiu a minha vista aos seus depósitos.

À Sra. Mar Pérez Milla, conservadora do Museo Víctor Balaguer de Villanueva y Geltrú, que não só possibilitou o acesso ao depósito do museu, como também me conduziu por uma inesquecível e exclusiva visita guiada, mesmo estando o museu fechado no dia da visita. 
Aos funcionários do Archivo Histórico Nacional da Espanha e do Centro de Ciencias Humanas y Sociales de Madri (Biblioteca Tomás Navarro), pela presteza e paciência. À Biblioteca Nacional de España, pela diponibilização online documentos utilizados nesta pesquisa.

A todos os professores, funcionários e colegas do Departamento de História da USP.

À Fapesp (Fundação de Amparo à Pesquisa do Estado de São Paulo) por ter viabilizado esta pesquisa através da concessão de bolsa de pesquisa. 


\section{Resumo}

Em nossa dissertação de Mestrado analisamos o conjunto de quatro pinturas retabulares encomendadas na década de 40 do século XVII para ornar a capela do hoje extinto Convento dos Capuchinhos da Paciência de Cristo de Madri (1651-1836). Estas pinturas narram a lenda que ficou conhecida como a do Santo Cristo da Paciência ou do Cristo das Injurias, e figuram o ataque de um grupo de pessoas a um crucifixo que, enquanto sofre tal desacato, expressa o seu poder milagroso através da fala e do jorro de sangue. Nosso objetivo foi, por meio da análise dessas pinturas, entender o significado das imagens religiosas para a cristandade espanhola deste período e o quanto os ataques iconoclastas preocupavam os membros da Igreja católica e seus fiéis de modo geral, a ponto de gerar a encomenda de tais obras. Para tal, investigamos este corpus de imagens em dois níveis fundamentais: analisando seus elementos formais e temáticos; e sua relação com o cristianismo - a encomenda e o debate sobre as imagens, sobre seus usos e funções nas práticas cultuais do catolicismo na Espanha do século XVII.

Palavras-chave: Cristo da Paciência; Iconoclastia; Imagens milagrosas; Espanha do século XVII. 


\begin{abstract}
In our master dissertation we analyzed the group of four altarpieces commissioned in the 1640s to decorate the chapel of the extinct Capuchin Convent of Patience Christ of Madrid (1651-1836). These paintings ndepict the legend that became known as the Holy Christ of the Patience or Christ of the Injuries, and represent the attack of a group of people to a crucifix which, while suffering such disrespect, expressed his miraculous power through speech and the blood gush. Our aim was, through the analysis of these paintings, to understand the meaning of these religious images for Spanish Christendom in this period and how the iconoclastic attacks were a source of worry for the members of the Catholic Church and the faithful in general so as to generate a commission for such works. For this purpose, we investigated this corpus of images on two fundamental levels: analyzing their formal and thematic elements; and its relation to Christianity - the commission and the debate about images, their uses and functions in cultual practices of Catholicism in seventeenth century Spain.
\end{abstract}

Keywords: Christ of the Patience; Iconoclasm; Miraculous images; Seventeenth century Spain. 


\section{Introdução}

O objetivo dessa dissertação de mestrado é analisar o conjunto de quatro pinturas retabulares que ornaram a capela do extinto Convento dos Capuchinhos da Paciência de Cristo de Madri. Estas pinturas narram a lenda que ficou conhecida como a do Santo Cristo da Paciência ou do Cristo das Injurias, e figuram o ataque de um grupo de pessoas a um crucifixo que, enquanto sofre tal desacato, expressa o seu poder milagroso através da fala e do jorro de sangue.

Para a religião cristã e depois católica, as imagens religiosas desempenharam um importante papel como meio para a expressão da fé, para a experiência devocional e para a própria expansão daquela religião. No entanto, no decorrer deste processo também houve controvérsias sobre seus usos e poderes, variando desde o debate de ideias até atos violentos contra as imagens (o que chamamos de modo geral de iconoclastia), consideradas equivocadas, enganosas, ou indignas de merecer culto. Porém, como no imaginário cristão muitas imagens religiosas poderiam ter o poder milagroso (virtus sancta) de atuar no mundo terrestre e interferir nas ações humanas, nestes contextos violentos surgiram várias lendas de que as próprias imagens religiosas teriam agido em sua defesa - e, portanto, em defesa da fé cristã. Em muitas destas lendas, ao serem atacadas, estas imagens teriam o poder sobrenatural de se manifestar, seja pela fala ou pela emissão de humores (sangue, suor, lágrimas), resistindo ao ataque, ou mesmo movendo-se, como é o caso das pinturas que aqui serão analisadas.

A primeira delas, Martirio del brasero del Cristo de la Paciencia de Andrés de Vargas (Figura 1), foi destruída em um incêndio em 1976 . A segunda, uma tela de Francisco Camilo, Ultrajes al crucifijo o Cristo de las injurias (Figura 2), pertence ao Museu do Prado, embora encontre-se atualmente depositada na Biblioteca-Museu Víctor Balaguer em Villanueva y Geltrú, distrito de Barcelona. A terceira, o quadro denominado Sacrilegio de unos judios: judios arrastando y azotan el crucifijo, pintado por Francisco Fernandez (Figura 3), também pertence ao acervo do Museu do Prado. E, por fim, o óleo sobre tela conhecido como Profanación de un crucifijo (Familia de

\footnotetext{
${ }^{1}$ MUSEO DEL PRADO. Inventario general de pinturas II. EI Museo de la Trinidad. Madrid: Espasa Calpe, 1991, p. 193.
} 
herejes azotando un crucifijo) foi pintado por Francisco Rizi (Figura 4), e também pertence hoje ao acervo do Museu do Prado.

Nas pinturas vemos a representação da tentativa de um grupo de pessoas, constituído por homens e mulheres, além de uma idosa e uma criança, de agredir o crucifixo. Apesar de as quatro pinturas tratarem da mesma injúria, em cada uma delas foi concebida uma forma diferente de representar o ataque. Vargas figurou dois momentos do ataque: no ambiente interno o crucifixo está sobre chamas e no externo, recebendo marteladas; na obra de Camilo, o crucifixo é posto para queimar; na de Fernandez, junto ao corpo de Cristo, que é flagelado pelos agressores, vemos a frase "porqve me maltratais siendo vuestro Dios verdadero", e na pintura de Rizi, o sangue de Cristo é representado a escorrer de sua cabeça, confundindo-se com a cor do chão. 


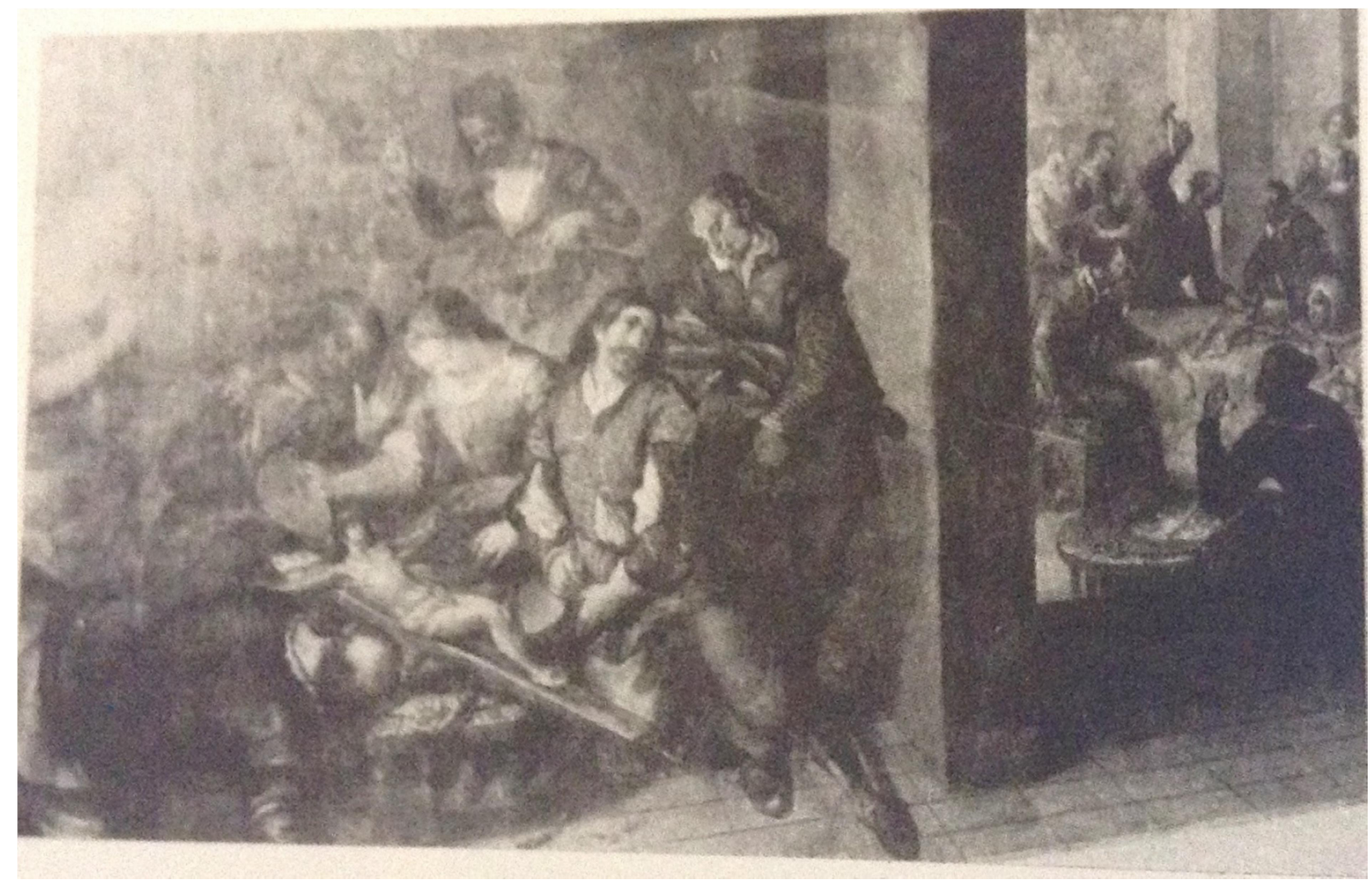

Figura 1 - Martirio del brasero del Cristo de la Paciencia, 1647-1651, óleo sobre tela, $171 \mathrm{com}$ x $296 \mathrm{~cm}$, Andrés de Vargas. Fonte: MUSEO DEL PRADO. Inventario general de pinturas II. El Museo de la Trinidad. Madrid: Espasa Calpe, 1991. 


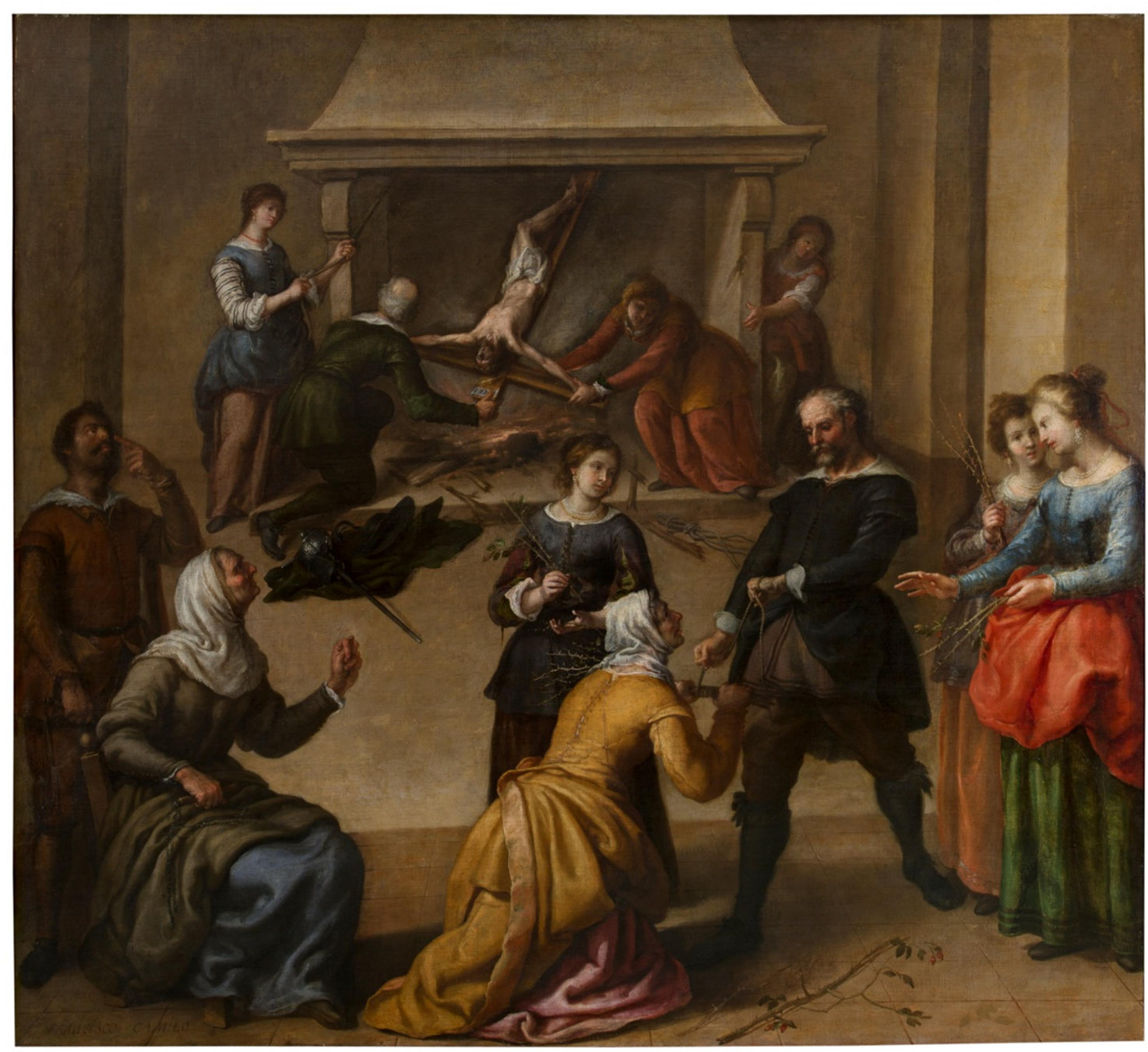

Figura 2 - Ultrajes al crucifijo o Cristo de las injurias, 1647-1651, óleo sobre tela, 210 $\mathrm{cm}$ x $231 \mathrm{~cm}$, Francisco Camilo, Museu do Prado, depositado na BibliotecaMuseu Víctor Balaguer em Villanueva y Geltrú. 


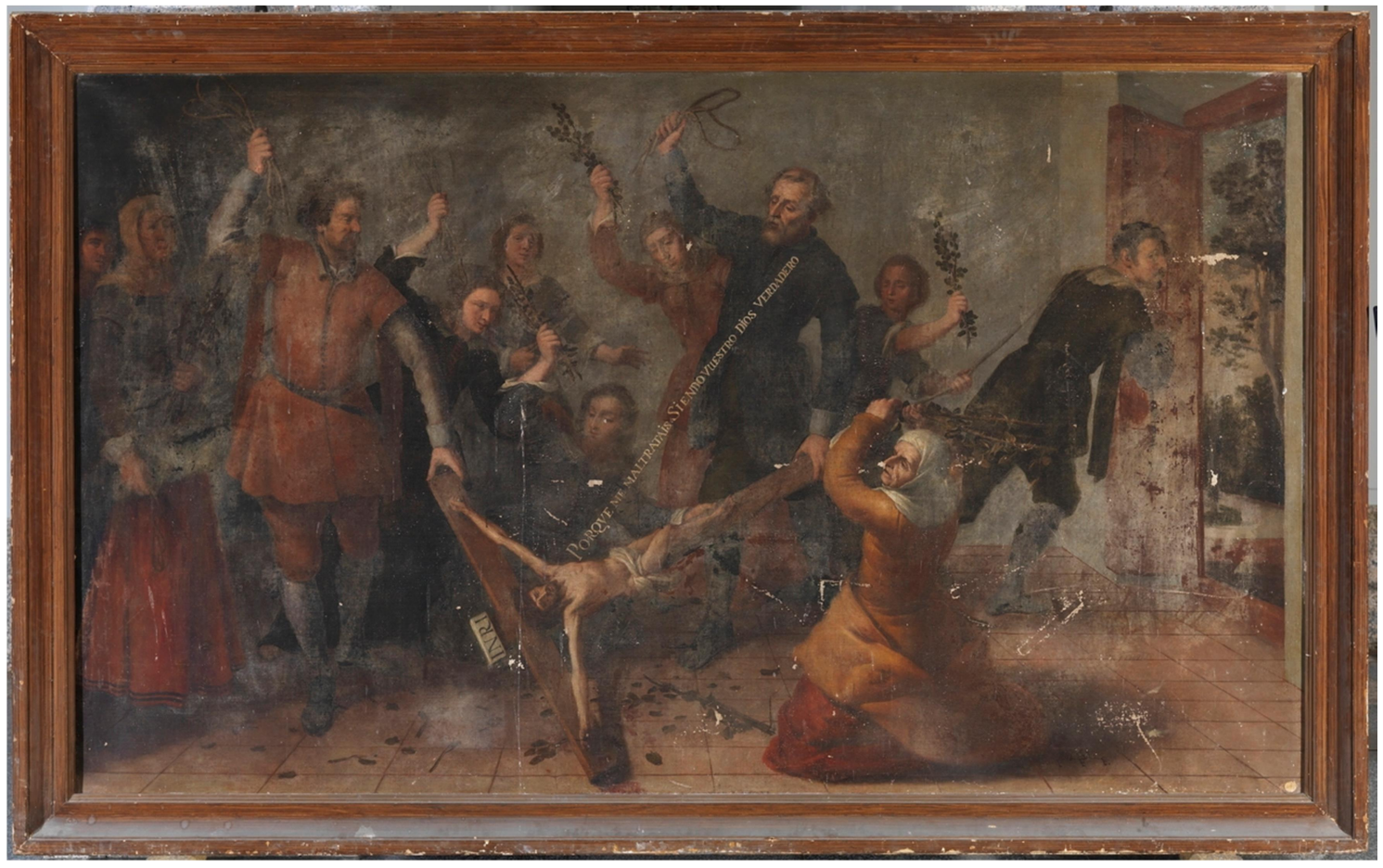

Figura 3 - Sacrilegio de unos judios: judios arrastando y azotan el crucifij, 1647-1651, óleo sobre tela, 171 x $296 \mathrm{~cm}$, Francisco Fernadez, Museu do Prado [P03873]. 


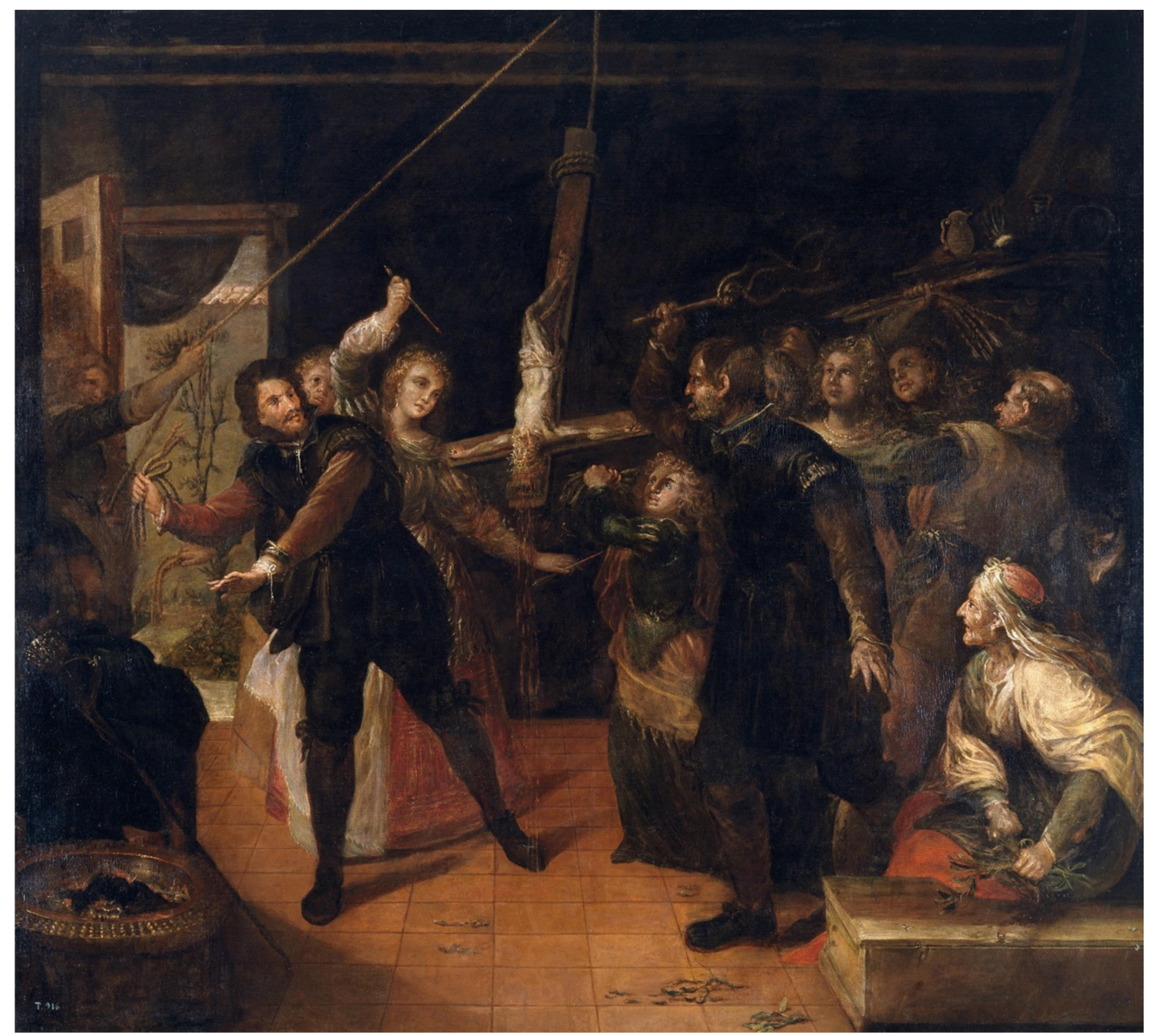

Figura 4 - Profanación de un crucifijo (Familia de herejes azotando un crucifijo), 16471651, óleo sobre tela, $207 \mathrm{~cm}$ x $230 \mathrm{~cm}$, Francisco Rizi, Museu do Prado [P03775]. 
A agressão teria ocorrido no ano de 1629, em Madri, na Calle de las Infantas, onde um grupo de criptojudeus portugueses teria profanado um crucifixo. $\mathrm{O}$ suposto ataque iconoclasta fora delatado pela também cristã-nova Juana da Silva, e em 1630 os acusados foram conduzidos ao cárcere do Santo Ofício de Toledo para interrogatório. O que mais chamou a atenção dos inquisidores foi o depoimento do filho mais novo de um dos acusados, chamado Andresillo, de seis anos de idade. A criança foi interrogada várias vezes, sempre confirmando tal profanação. Mas no último interrogatório acrescentou um fato que acirrou os ânimos dos Inquisidores, declarando que, ao ser açoitada, a imagem do Cristo crucificado teria questionado seus algozes e sangrado.

Tais notícias geraram muita comoção, e o Auto da Fé que deveria ocorrer em Toledo foi transferido para Madri, para que o rei Felipe IV e a rainha Isabel de Bourbon pudessem assistir a solenidade pública e religiosa da expiação dos réus. $\mathrm{O}$ grande ato aconteceu no dia 4 de julho de 1632 na Praça Maior, e os seis réus foram penitenciados e relaxados à justiça secular. Após o castigo, ainda foram organizados vários atos e procissões em reparação ao ataque ao crucifixo. Criaram-se várias confrarias e publicaram-se escritos piedosos sobre o caso. Dias após o Auto de Fé, a casa em que os acusados moravam foi destruída, para que em seu lugar fosse construído um templo expiatório. Sob o patronato da Rainha Isabel de Bourbon, em 1639 a igreja da comunidade Capuchinha foi erguida, e as quatro pinturas retabulares encomendadas para as paredes da capela foram finalizadas em 1651, data da consagração da igreja e inauguração do convento dedicados ao Cristo que padeceu sob os hereges, que ganhou então a invocação de Cristo da Paciência (Figura 5). 


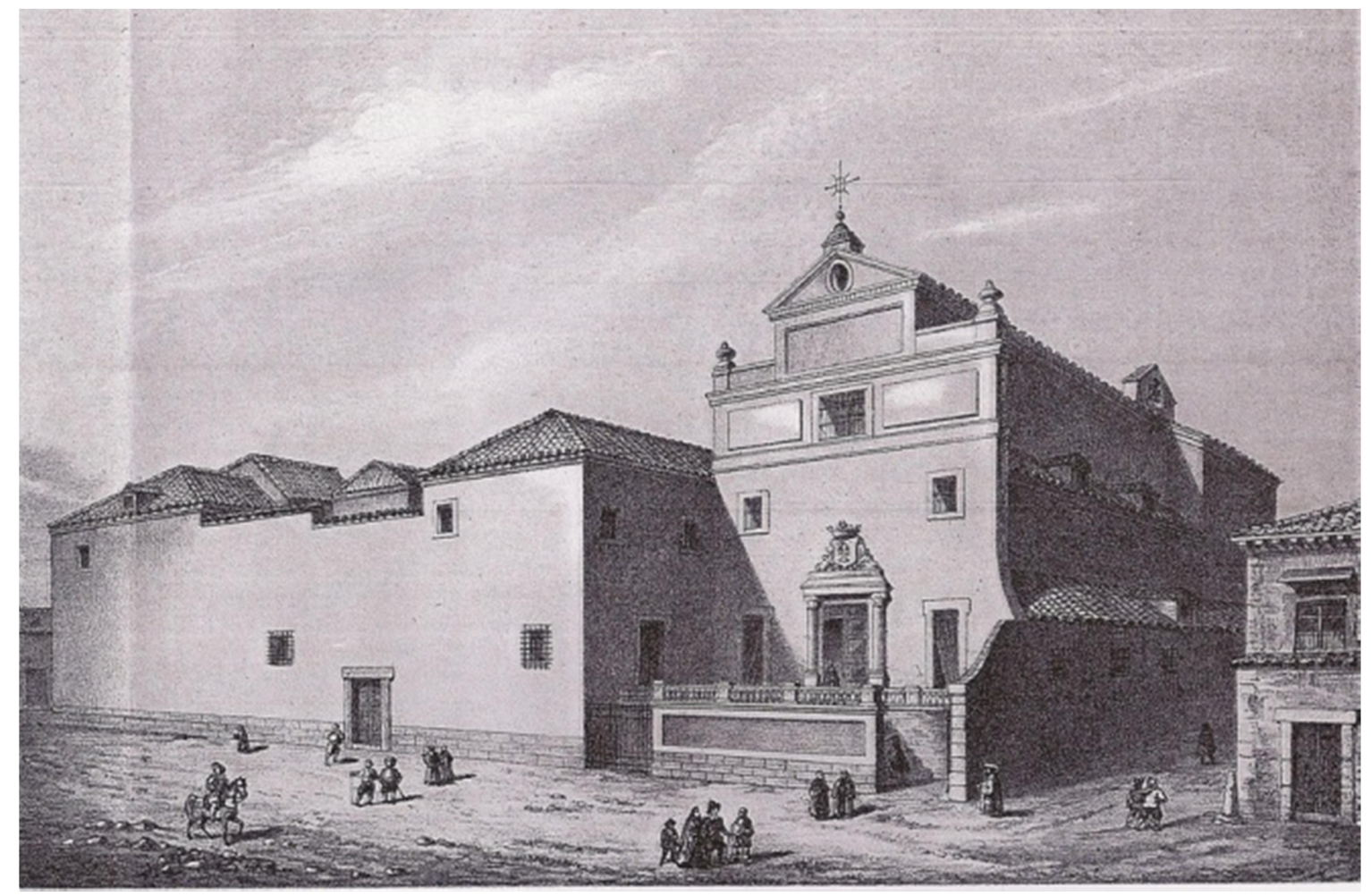

Figura 5 - Iglesia y Convento Capuchinos de la Paciencia, 15,5 cm x 22,3 cm, litografia, c. 1863, Biblioteca Nacional da Espanha [45981]. 
Este não teria sido o único ataque iconoclasta ocorrido na Península Ibérica: podemos citar também o exemplo do ataque à Ermida de Nossa Senhora das Ervas na pequena cidade de Alandroal, em Portugal, em 1551, quando um grupo de pessoas invadiu uma igreja arrancando suas portas, destruindo vários aparatos religiosos e, por fim, queimando várias imagens de santos, caso que aparece na documentação da Inquisição de Évora ${ }^{2}$. Não obstante tendemos a associar as agressões às imagens religiosas nesse período aos ataques iconoclastas protestantes e calvinistas como em Zurique $(1523)^{3}$, em Münster (1534) ${ }^{4}$, em Genebra (em agosto de 1535 os ataques iconoclastas foram o evento de consolidaram a reforma) ${ }^{5}$ e em Utrecht (Beeldenstorn em 1566) ${ }^{6}$, o exemplo de Alandroal e o caso do Cristo da Paciência demonstram que casos de iconoclastia não foram apanágio das regiões em que a religião cristã desvinculou-se da Igreja de Roma. Em um olhar mais atento às produções artísticas e religiosas ibéricas, deparamo-nos com pinturas, gravuras e sermões que tematizam casos de ataque às imagens sagradas. Investigando a documentação do Tribunal do Santo Ofício, encontramos diversas denúncias e processos cujas acusações foram o desrespeito aos objetos visuais considerados sagrados para os católicos. Cabe ressaltar que, para os cristãos que se mantiveram fiéis à Igreja de Roma, as imagens religiosas, além de partícipes de práticas religiosas já consagradas havia muito pela Igreja, poderiam também ser detentoras de poderes ${ }^{7}$.

\footnotetext{
${ }^{2}$ Queimaram uma imagem de Santo Amaro, uma de Nossa Senhora com o Menino e outra da Virgem. MEA, Elvira Cunha de Azevedo Silva. Nossa Senhora em processos da Inquisição. Revista da Faculdade de Letras: História. Porto, 1994, vol, p. 155. O processo não está digitalizado, mas suas referencias são: ANTT, Tribunal do Santo Oficio, Inquisição de Évora, proc. 11579. Além deste caso, no decorrer de nossa dissertação iremos apontar outros exemplos.

${ }^{3}$ Quando uma imagem de santa Catarina e outra de São João foram desrespeitadas e depois queimadas. HABICHT, Peter. Des iconoclastes forcent deux saints à coucher ensembre et décapittent une statue du Christ. In: DUPEAUX, Cécile; JEZLER, Peter e WIRTH, Jean. Cataloque de l'exposition: Iconoclasme: vie et mort de l'image médievale. Paris: Somogy, 2001, p 116.

${ }^{4} \mathrm{Em}$ Münster, forma os anabatistas que eliminaram todas as imagens. BELTING, Hans. Semelhança e Presença. Rio de Janeiro: ARS URBE, 2010, p. 582.

${ }^{5}$ BELTING, Hans. Semelhança e Presença: a história da imagem antes da era da arte, 2010, p. 582.

${ }^{6}$ Os ataques de Utrecht, em 1566 foram o ápice do Beeldenstorn, palavra holandesa que significa ataques iconoclastas, dirigidos contra a Igreja Católica e Felipe II da Espanha. Lembremos que o poder imperial dos países baixos neste momento esta sob o comando de Felipe II. FREEDBERG, David. Art and Iconoclasm, 1525-1580. Kunst, 1986, p 69-80.

${ }^{7}$ Sobre as funções das imagens religiosas no cristianismo, ver: BASCHET, Jérôme. A civilização feudal: do ano mil à colonização da América. São Paulo: Globo, 2006; BELTING, Hans. Semelhança e Presença: a história da imagem antes da era da arte, 2010; SCHMITT, Jean-Claude. O corpo das imagens. Ensaios sobre a cultura visual na Idade Média. São Paulo: Edusc, 2007; FREEDBERG, David. El poder de las Imágines: estudios sobre la historia y la teoria de la respuesta. Madrid: Cátedra, 1992, entre outros.
} 
Tomando em consideração os diversos significados que as imagens poderiam assumir para os católicos, o objetivo de nossa dissertação foi o de analisar este conjunto de pinturas retabulares cujo tema principal é o ataque às imagens sagradas, a fim de compreendermos o significado das imagens religiosas para a cristandade espanhola deste período e o quanto os ataques iconoclastas preocupavam os membros da Igreja católica e seus fiéis de modo geral, a ponto de gerar a encomenda das pinturas que elencamos. Para tal, investigamos este corpus de imagens em dois níveis fundamentais: analisando seus elementos formais e temáticos; e sua relação com o cristianismo - a encomenda e o debate sobre as imagens, sobre seus usos e funções nas práticas cultuais do catolicismo na Espanha do século XVII.

Para alcançar o nosso objetivo, foi necessário analisar também o processo de construção do templo, a feitura das pinturas e a posterior devoção ao Cristo da Paciência, bem como a complexidade das questões que permeavam os debates sobre o culto às imagens religiosas na Espanha do Século de Ouro. Também temos de levar em consideração a atitude negativa dos cristãos-velhos em relação aos judeus e aos cristãosnovos, configurado ao longo de séculos de convivência peninsular, juntamente com a crescente devoção centrada na figura de Cristo sofredor que comovia, ou deveria comover, toda a sociedade cristã-velha (agora católica) espanhola. Estamos falando, pois, de múltiplos planos ideológicos e simbólicos que se amalgamaram diante da notícia do milagre da imagem de Cristo, e trouxeram para as calles madrileñas o episódio central do cristianismo, a Paixão de Cristo, e a responsabilidade judaica, sacralizando aquela vizinhança que na época ficou conhecida como La Nueva Jerusalé $^{8}$. Isso demonstra que, em muitos casos, o uso das imagens esteve na base de conflitos entre as comunidades de cristãos-velhos e os recém-conversos, e que tais questões ultrapassaram o âmbito teológico.

É mister advertir que as imagens que analisaremos são fruto da versão oficial da Inquisição espanhola, e que apesar de tratar dos "fatos" que culminaram na encomenda das pinturas, nossa investigação, apesar de compreendermos a necessidade da análise

\footnotetext{
8 “...tras el Auto de Fe del verano de 1632, aquel lugar se convertiría en un espacio sagrado, en un santuario, donde confluirían miles de devotos, en masa o individualmente, para venerar el recuerdo del milagro acaecido allí. La nueva Jerusalén; con este nombre se conocería por entonces este enclave madrileño." PULIDO SERRANO, Juan Ignacio. Injúrias a Cristo: religión, política y antijudaísmo en el siglo XVII. Alcalá de Henares: Instituo Internacional de Estudios Sefardíes y Andalusíes - Universidad de Alcalá, 2002, p. 272.
} 
histórica que questionasse e discutisse a veracidade ou os possíveis motivos das acusações $^{9}$, não incluiu tais questionamentos, pois nossa proposta de pesquisa foi a análise das imagens e suas múltiplas funcionalidades naquele meio social.

Outro ponto importante de nossa pesquisa foram os motivos figurados: um grupo de pessoas atacando um crucifixo. Nas imagens que analisamos, a escultura tridimensional é figurada em duas dimensões, com o que se pretende manter seu sentido original (o de escultura que funciona dentro de uma prática visual) e ao mesmo tempo dar um significado transcendente à sua realidade escultórica ao figurar a sua atuação mística ou milagrosa. Na Espanha do Século de Ouro, algumas pinturas conseguem criar a ilusão da tridimensionalidade dos objetos figurados, como a pintura La Santa Faz de Francisco Zurbarán (Figura 6). Tal efeito foi denominado pelo historiador da arte Alfonso Perez Sánchez de "trampontojo a lo divino", semelhante ao "trompe-l'oeil", 10 recurso que no século XVII foi muito utilizado, por exemplo, nas pinturas de bodegones (naturezas-mortas) $^{11}$. O historiador Rodriguez Ceballos, quando escreve sobre "trampontojo a lo divino", diz que tanto na Espanha como na América estas pinturas figuraram imagens de culto do modo como elas são cultuadas, em altares ou retábulos, com seus adornos (trajes, joias, velas, vasos). O pintor deveria esforçar-se em sua técnica para fazer com que o espectador pudesse pensar que estava vendo a imagem de culto e não uma representação desta ${ }^{12}$.

\footnotetext{
${ }^{9}$ Para uma investigação detalhada sobre os possíveis interesses e manipulações na condenação desta família de judeus conversos ver: PULIDO SERRANO, Juan Ignacio. Injúrias a Cristo: religión, política y antijudaísmo en el siglo XVII, 2002.

${ }^{10}$ Mesmo sendo uma palavra moderna, o conceito de trompe-l'oeil, como uma ilusão pictórica, é muito antigo, presente em textos gregos, como no livro XIV da Geografia $(29 \mathrm{aC})$ de Estrabão e romanos como no Livro XXXV da História Natural (79 dC) de Plinio, o Velho. Este conceito gerou questões filosóficas (ilusão, engano, imitação) e técnicas (perspectiva, claro e escuro, uso da cor) no âmbito das artes visuais, e foi amplamente debatido em BAUDRILLARD, Jean; CALABRESE, Omar. El trompe-l'oeil. Madrid: Casimiro, 2014.

11 PÉREZ SANCHES, Afonso. Apud: RODRIGUEZ CEBALlOS, Alfonso. "Trampantojos a lo divino": iconos pintados de cristo y de la virgen a partir de imágenes de culto en América meridional. In: In: III CONGRESO INTERNACIONAL DEL BARROCO AMERICANO. Sevilla: 2001. Atas... Sevilla: Territorio, Arte, Espacio y Sociedad: Universidad Pablo de Olavide, 2001, p. 24.

${ }^{12}$ RODRIGUEZ G. DE CEBALLOS, Alfonso. "Trampantojos a lo divino": iconos pintados de cristo y de la virgen a partir de imágenes de culto en América meridional, 2001. p. 26.
} 


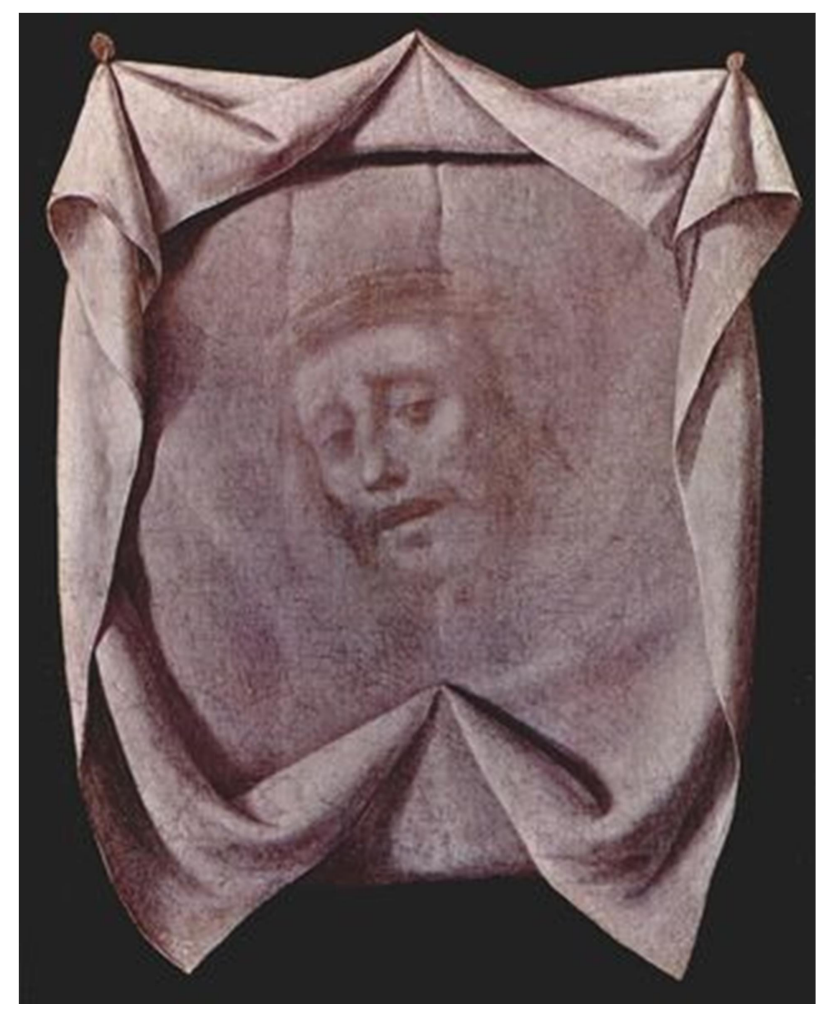

Figura 6 - La Santa Faz, c. 1631, óleo sobre tela, 70 cm x 51,5 cm, Francisco Zurbarán, Museu de Belas Artes da Suécia [NM 5382].

Podemos, portanto, considerar o "trampontojo a lo divino" como um recurso de persuasão, o que não se aplica às pinturas ora analisadas, pois não percebemos a intenção figurar o objeto religioso em sua realidade física para criar ilusionismo, mas sim de narrar fatos ocorridos com as imagens sagradas e a partir daí explicitar suas virtudes milagrosas. Os pintores das obras que estudamos utilizaram o mecanismo da metalinguagem visual para representar tanto o ato iconoclasta como o potencial sacro da imagem cristã, o que iremos denominar meta-imagem.

Em dois de seus livros, Victor Stoichita analisa imagens que fazem uso de recursos similares. Em L'instauration du tableau: Métapeinture à l'aube des temps modernes, a meta-imagem é a metapintura que intitula a obra, ou seja, nela ele analisa um conjunto de pinturas cuja estratégia de retórica visual se refere à própria pintura e aos instrumentos que a engendram ${ }^{13}$. Já na obra El Ojo Mistico, Stoichita está preocupado em compreender como, na Espanha dos séculos XVI e XVII, os artistas

\footnotetext{
${ }^{13}$ STOICHITA, Victor. L'instauration du tableau: Métapeinture à l'aube des tempes modernes.
} Geneva: Droz, 1999. 
figuravam o irrepresentável: as visões místicas. Para tanto, o autor escolheu um conjunto de imagens em que o recurso visual metalinguístico foi usado como um mecanismo de tornar sensível tal experiência mística ${ }^{14}$. Em suma, com base em nossas leituras das duas obras citadas, optamos pelo termo meta-imagem para designar tanto a representação de uma imagem religiosa, como escultura, pintura ou um objeto sagrado, como a representação de fenômenos associados à percepção visual mística, a ação ou a reação milagrosa da imagem religiosa.

Todas as pinturas que analisamos compartilham dessa tática metalinguística de retórica visual: a meta-imagem. Na amostragem selecionada, as pinturas representam o ataque iconoclasta ao crucifixo. Nelas pode-se perceber uma dupla estratégia de retórica visual, tanto para a figuração dos objetos sagrados como para aquilo que foge à experiência sensorial cotidiana: a reação da pessoa santa ou divina desrespeitada, traduzida pela concretização do sofrimento da sua imagem, figurando tanto a sacralidade dos objetos religiosos como o significado da iconoclastia para os católicos. Sendo assim, recorremos, em nossa pesquisa, à meta-imagem como uma categoria analítica, uma ferramenta para compreender as múltiplas funções das imagens religiosas figuradas em nossas pinturas. Ou seja, buscamos apreender a gênese de cada pintura, suas soluções compositivas para representar o desdobramento do mundo físico em sagrado, para daí compreender o potencial místico das imagens religiosas naquele meio social.

Ainda no âmbito da análise "interna" $" 15$ ou sintática, como conceituou JeanClaude Bonne ${ }^{16}$, dos elementos que compõem as estruturas significantes nas pinturas, tanto do que diz respeito à figuração do milagre quanto à representação dos hereges que agridem o símbolo de maior importância para a fé católica espanhola, necessitaremos utilizar uma abordagem comparativa. No caso da figuração do herege, recorremos a imagens que nos pareceram denotar e/ou conotar o herege e seu pecado, por sua fisionomia, vestes, cores, gestos, e outros objetos que simbolizem rituais considerados ímpios. E para a ação milagrosa das imagens religiosas, nossa intenção foi buscar

\footnotetext{
${ }^{14}$ STOICHITA, Victor I. El ojo místico: Pintura y vision religiosa en el Siglo de Oro español. Madrid: Alianza, 1996. p. 13.

${ }^{15}$ Utilizamos a expressão "análise interna" tomando por base os estudos de textos, mas deixamos entre aspas, pois nos referimos às imagens.

${ }^{16}$ Para Bonne, o conceito de sintática é a "análise das propriedades plásticas e cromáticas enquanto elas constituem estruturas significantes e não somente formais ou representacionais". BONNE, Jean-Claude. L'art Roman de face et de profil: Le tympan de Conques. Paris: Le Sycomore, 1984, p. 18.
} 
imagens em que a estratégia retórica do artista foi capaz de fazer visível a atuação mística de um objeto visual religioso. Também circunscrevemos esta escolha à Peninsula Ibérica, mas não nos limitamos às pinturas retabulares, pois incluímos também imagens de manuscritos iluminados ${ }^{17}$, gravuras e um relevo. Devemos esclarecer que nossa intenção não foi a de encontrar um padrão ou uma fórmula iconográfica do herege e de seus atos ou das imagens milagrosas. Nossa finalidade é problematizar tais representações, incluindo suas ambivalências e incoerências, como parte do processo para concretizar o objetivo de nossa pesquisa de mestrado.

Para finalizar, entendemos que estas quatro imagens que constituem nosso corpus principal formam um corpo passível de ser analisado como um conjunto, pois possuem a mesma temática principal, ou seja, a iconoclastia contra um crucifixo, e fazem uso da metalinguagem visual para representam um objeto religioso - e duas delas ultrapassam esse limite ao figurar a reação milagrosa do crucifixo. Além disso, são pinturas do gênero narrativo e fizeram parte de retábulos de altares laterais de uma mesma capela, com uma temática que destoa da tradição retabular, uma vez que os retábulos, sobretudo os centrais, são objetos destinados, em geral, "a inserir a liturgia cristã num contexto visual” ${ }^{\prime 18}$, e a eucaristia constitui sua razão primeira ${ }^{19}$, de modo que geralmente destinam-se à representação de narrativas da vida de Cristo.

Como já citado, a principal opção para análise destas quatro pinturas foi a sua temática, além das circunstâncias de sua encomenda e sua presença em uma mesma igreja. Porém gostaríamos de ressaltar que este corpus interessa-nos também pelo seu “esquecimento". Consideramo-nas pinturas esquecidas porque são pouco estudadas, algumas incorretamente catalogadas e outras mesmo carentes de restauro. A despeito das pinturas serem fruto de acontecimento que teria comovido ${ }^{20}$ a corte madrilena no século XVII, das quatro pinturas que figuram o ataque ao crucifixo, uma foi perdida no já referido incêndio e as demais atualmente não estão em exibição. De início, encontramos pouquíssimos artigos e notas sobre estas imagens, com informações

\footnotetext{
17 Como o canto XII das Cantigas de Santa Maria, Códice Rico, T.Ms.T-I-1, Real Biblioteca del Monasterio de San Lorenzo de El Escorial, fol 20v.

${ }^{18}$ SALTEIRO, I. Do retábulo, ainda: aos novos modos de fazer e pensar. 2005. Tese (Doutorado em Belas artes) - Faculdade de Belas Artes, Universidade de Lisboa. Lisboa, 2005. p. 37.

${ }^{19}$ GONZALEZ, J. Avance de una tipologia del retablo barroco. Imafronte, 1987-89, n. 3-5, pp. 112-113.

20 "no se puede negar es que, una vez hecho público [o ataque e o milagre], produjo en toda España, especialmente en Madrid, una conmoción incalculable.” RODRIGUEZ CEBALLOS, Alfonso. El Cristo Crucificado de Velásquez: Transfondo histórico-religioso. Revista Archivo Español de Arte, 2004, LXXVII, pp. 13-14.
} 
incorretas, que nos levaram a procurar a pintura de Francisco Fernandez na paróquia de Setados, na Galícia ${ }^{21}$ onde a pintura esteve até 1969, conforme descobrimos no Inventário General del Museo del Prado, na Biblioteca do Museu do Prado. Na ocasião constatamos que a pintura estava no próprio museu, mas infelizmente não tivemos acesso a ela. Pudemos ver as pinturas originais de Francisco Camilo conservadas na Biblioteca-Museu Víctor Balaguer, e de Francisco Rizi, no Museu do Prado. Apesar de estarem fora de exposição tivemos acesso aos depósitos em que se encontravam, e observamos atenciosamente os seus detalhes materiais e formais, e constatamos o ótimo estado de conservação delas.

O maior estudo que contempla também as imagens aqui analisadas é a obra de Juan Ignacio Pulido Serrano Injurias a Cristo: religión, política y antijudaímo em el siglo $X V I I^{22}$. O objetivo do seu trabalho foi investigar a condenação de um grupo de comerciantes portugueses criptojudeus, e no seu entender, mesmo antes do processo inquisitorial iniciar-se, a condenação dos acusados já era certa, pois teriam sido escolhidos como bodes expiatórios para aplacar a onda de ódio aos cristãos-novos portugueses gerada pela política de tolerância do Duque de Olivares ${ }^{23}$. Já sobre a construção do Convento e as pinturas, tratados no capítulo VIII La Iglesia y convento de los capuchinos del santíssimo Cristo de la Paciencia, Pulido Serrano descreve as imagens e aponta que elas funcionariam para perpetuar na memória coletiva todo esse conteúdo ideológico. Em nenhum momento o autor questiona as imagens como objeto de culto, nem a maneira como foram figuradas, ou as múltiplas funcionalidades das imagens cristãs. A sua análise se baseia em fontes textuais cujo foco é a política de Felipe IV dirigida aos cristãos-novos.

Com um olhar mais direcionado às obras de arte, podemos citar o texto " $E l$ Cristo Crucificado de Velásquez”, em que o historiador da arte Afonso Rodriguez Ceballos relaciona a encomenda da pintura El Cristo Crucificado à Velásquez ao caso do Cristo de la Paciencia, descrevendo-o muito bem, mas apenas citando as pinturas

\footnotetext{
${ }^{21}$ PÉREZ SÁNCHEZ, Alfonso. Pintura Barroca en España: 1600-1750. Madrid: Cátedra, 2010, p. 92; SERRÃO, Vitor. Pintura e Propaganda em Évora nos alvores do século XVII: um panfleto contra a iconoclastia e dois casos de repressão. In: BARRETO, Luís Filipe. Inquisição portuguesa: tempo razão e circunstancia. Lisboa: Prefácio, 2007, p. 429.

${ }^{22}$ PULIDO SERRANO, Juan Ignacio. Injúrias a Cristo: religión, política y antijudaísmo en el siglo XVII, 2002.

${ }^{23}$ PULIDO SERRANO, Juan Ignacio. Injúrias a Cristo: religión, política y antijudaísmo en el siglo XVII, 2002. pp. 37-51.
} 
encomendadas para registrar os agravos dos criptojudeus portugueses que teriam sido cometidos em Madri ${ }^{24}$. Podemos também lembrar da historiadora da arte brasileira Benair A. F. Ribeiro que, em sua tese de doutoramento para o departamento de História da USP: Arte e Inquisição na Península Ibérica, menciona o caso do Cristo da Paciência, e apresenta somente a pintura Profanacion de un crucifijo de Francisco Rizi, e aponta que, dentre as demais pinturas similares, esta seria aquela cujo estilo seria o iniciador da escola madrilena de pintura ${ }^{25}$, o que a nosso ver não contribui para nosso objetivo.

Michael Scholz-Hänsel, em seu livro Inquisition und Kunst: Convivencia in Zeiten de Intoleranz, publicado em 2009, dedica um capítulo ao caso do Cristo da Paciência, com o título: Ein Aufruf zur Intoleranz im Convento de los Capuchinos de la paciência de Cristo in Madrid (pp.144-153). Nele aponta a insuficiência de estudos e faz alguns questionamentos sobre os elementos formais das imagens, como o que existe de comum nas pinturas, porém não nos parece encontrar uma resposta efetiva ${ }^{26}$.

Em 2010, a historiadora da arte Marta Bustillo publicou um artigo no livro Imaginary, Spirituality and Ideogy in Baroque Spain and Latin America cujo título é "The Episode of the Cristo de la Paciencia and Its Influence on Religious Imaginary in Seventeenth-Century Madrid'. Aqui a autora faz uma análise do uso das imagens das confrarias que surgiram para difundir o culto ao Cristo de la Paciencia, e também ressalta a necessidade de se fazer um estudo do papel das imagens religiosas nos meios sociais após o ocorrido. E sobre as pinturas e o convento, diz que seus estudos já foram

\footnotetext{
${ }^{24}$ A partir da leitura de denúncias do Santo Oficio, o autor observa que, além da profanação cometida, há relatos do filho dos condenados descrevendo um milagre, no qual a imagem de Jesus teria sangrado e falado. Tal fato, o agravo ao crucifixo, teria gerado muita comoção e um sentimento de luto por toda Espanha, assim logo após a condenação no auto-de-fé de 1632, mandou-se construir no exato local da casa onde o sacrilégio teria acontecido, um Convento dos Capuchinos da Paciência de Cristo, além de serem organizadas muitas procissões e cerimônias de reparação aos pecados cometidos. RODRIGUEZ CEBALLOS, Alfonso. El Cristo Crucificado de Velásquez: Transfondo histórico-religioso, 2004, pp. 1316.

${ }^{25}$ RIBEIRO, Benair Alcaraz Fernandes. Arte e Inquisição na Península Ibérica. Tese (Doutorado em História Social) - FFLCH - Departamento de História. UPS. São Paulo 2006, p. 170.

${ }^{26}$ No entanto, dois pontos nos chamam a atenção, primeiramente sobre a única pessoa que foi representada em dois momentos na Inquisição espanhola, Ana Mendez, filha de Miguel Rodriguez e Isabel Nunes, que não foi condenada pelo Tribunal de 1632, mas sim no ano de 1660 em Sevilha. No entanto, a jovem foi figurada nas pinturas para o convento dos Capuchinhos da Paciência, e também na pintura Auto de Fe en la Plaza de San Francisco de Sevilla en el año de 1660, de Francisco Herrera, o Moço. Outro apontamento de interesse é uma nota sobre sua impressão de que a Espanha do século XIX parecia trabalhar para esconder ou destruir provas das ações da Inquisição. Trata-se de um comentário interessante e merecedor de maior investigação, o que, entretanto, foge ao escopo do presente estudo. SCHOLZ-HÄNSEL, Michael. Inquisition und Kunst: Convivencia in Zeiten de Intoleranz. Berlin: Frank \&Timme, 2009. pp.144-153.
} 
elaborados pelos já citados de Pulido Serrano e de Michael Scholz-Hänsel ${ }^{27}$, mas como dissemos, para o nosso entendimento tais objetos devem receber outras abordagens.

Finalmente, podemos citar a tese de doutoramento Hacia una teología de la imagen. Mística, oratória y pintura en la España del Siglo de Oro ${ }^{28}$, de Darío Velandia Onofre, defendida em 2014 no Departamento de História da Arte da Universidade de Barcelona. Em sua pesquisa, Velandia Onofre investigou o papel do fiel como receptor de imagens sagradas no século XVII, tanto por meio de pinturas da Paixão de Cristo como pela literatura religiosa, e dedicou o subcapítulo "Feliz escandalo del judio". La imagen violentada ao caso del Cristo de la Paciencia. Aqui ele não analisa as imagens, seu objetivo foi o de analisar os sermões que trataram do agravo às imagens, com a intenção compreender o uso e as funções das imagens sagradas e suas relações com o fiel. A despeito de apenas apresentar as imagens, esta tese foi importante para nossa pesquisa, pois foi por meio de sua leitura que pudemos perceber como o cristocentrismo enraizado na sociedade espanhola do século XVII foi determinante para a compreensão da comoção que a notícia do ataque a um crucifixo teria gerado nos fiéis madrilenos. Além destes trabalhos, podemos ainda aludir a outros que apenas citam as pinturas, fazendo referência às denúncias encontradas na documentação do Santo Ofício ${ }^{29}$.

\footnotetext{
${ }^{27}$ BUSTILLO, Martha. The Episode of the Cristo de la Paciencia and Its Influence on Religious Imaginary in Seventeenth-Century Madrid. In: BUSTILLO, Martha; ROE Jeremy. Imaginary, Spirituality and Ideogy in Baroque Sapin and Latin America. Newcastle upon Tyne: Cambridge Scholars Publishing. 2010, p. 61.

${ }^{28}$ VELANDIA ONOFRE, Darío. Hacia una teología de la imagen. Mística, oratória y pintura en la España del Siglo de Oro. Tese (Doutorado em História da Arte) História, Teoria i Critica de les Arts Univercidade de Barcelona, Barcelona, 2014.

${ }^{29}$ Como os artigos de: HEIPLE, Daniel L. Political Posturing on the Jewish Question by Lope de Vega and Faria e Sousa. Hispanic Review, 1994, vol. 62, n 2, pp. 219-221; CARO BAROJA, Julio. Inquisición, brujería y criptojudaísmo. Madrid: Arial, 1970. pp. 65-70 e Los Judíos en la España Moderna y Contemporánea. Madrid: Istmo, 1978. pp. 445-447.
} 


\section{As imagens religiosas na Espanha do século XVII: usos e funções}

Para melhor compreender nosso corpus e alcançar nosso objetivo precisamos entender como as imagens funcionavam no meio social em que estavam incorporadas, e será desta questão que iremos tratar neste capítulo 2. Partimos, pois, de uma base teórica já muito bem elaborada por historiadores como Jean-Claude Schmitt, Jérôme Baschet e Georges Didi-Hubberman, juntamente com alguns exemplos contemporâneos às imagens analisadas.

As imagens religiosas são objetos materiais feitos por homens, e seriam (ou deveriam ser) apenas objetos que representam um santo ou Cristo, logo não poderiam ter vida em si, como resumido no Concílio de Trento ${ }^{30}$. No período que estudamos, foram elaborados muitos tratados que esclarecem que as imagens sagradas deveriam ser compreendidas como objetos que apenas representam e não possuem divindade alguma, como os Comentários al Catecismo de Bartolomé Carranza de Miranda ${ }^{31}$. Porém, mesmo entre os eclesiásticos, podemos citar duas exceções: Frei Hernando de Talavera, com o texto Católica Impugnación del herético libelo, no qual admite que existam imagens que possam adquirir poder milagroso ${ }^{32}$, e o cardeal e tratadista Gabriel Paleotti que em seu Discorso intorno alle imagini sacre et profane também aceita que algumas imagens seriam capazes de interferir no mundo físico ${ }^{33}$. Do ponto de vista do fiel, como alguns estudos historiográficos apontam ${ }^{34}$, ou de lendas como a do Milagre de Segóvia ${ }^{35}$

\footnotetext{
30 “...devem-se ter e conservar, especialmente nos templos, imagens de Cristo, da Virgem mãe de Deus e dos outros santos e a elas se deve conferir a devida honra e veneração, não porque se acredite que haja nelas alguma divindade ou virtude em razão da qual deveriam ser cultuadas...". Decreto sobre a invocação, a veneração e as relíquias dos santos e sobre as imagens sagradas. LICHTENSTEIN, Jacqueline. A pintura: textos essenciais. Vol. 2: A teologia da imagem e o estauto da pintura. São Paulo: Editora 34, 2008, p. 67.

31 “...las obras que han hecho los hombres por sus manos y otras muestras que no tienen vida en sí, y mucho menos tienen divindad alguna..." MARTÍNEZ-BURGOS GARCIA, Palma. Ídolos e Imágenes: la controversia del arte religioso en el siglo XVI español Valladolid: Universidad Valladolid/Caja Salamanca, 1990, pp. 40-41.

${ }^{32}$ TALAVERA, Frey Hernando de, Católica Impugnación, Barcelona: Juan Flores, 1961, Capitulo 54. Pp.189-190.

${ }^{33}$ PALEOTTI, Gabriel. Discorso intorno alle imagini sacre et profane. Livro I, cap. XVI. Bologna, 1582.

${ }^{34}$ Citamos alguns exemplos: BASCHET, Jérôme. A civilização feudal: do ano mil à colonização da América, 2006; BELTING, Hans. Semelhança e Presença: a história da imagem antes da era da arte, 2010; DIDI-HUBERMAN, Georges. Diante da Imagem: questão colocada aos fins de uma história da arte. São Paulo: Editora 34, 2013; SCHMITT, Jean-Claude. O corpo das imagens. Ensaios sobre a cultura visual na Idade Média, 2007.

${ }^{35}$ Segundo Francisco Yepes, o milagre teria ocorrido em 1588 quando uma pintura de Cristo teria falado com Juan de la Cruz: "Hermano Juan, pídeme lo que tú quieras, que voy a concedértelo por el servicio
} 
e o milagre do Cristo de la Paciencia indicam, percebemos que as imagens religiosas eram consideradas como possuidoras do poder de fazer presente o sagrado, o que denota um desacordo entre a ortodoxia e os múltiplos usos das imagens religiosas cristãs.

Ou seja, a despeito das normas conciliares, para os fiéis as imagens seriam capazes de apresentar para o espectador o que é ausente em sua realidade física: através de seus poderes milagrosos exibem a realidade divina capaz de proteger e advogar pelo devoto $^{36}$. O culto às imagens proporcionaria ao devoto um momento privilegiado, remetendo aos indícios da semelhança perdida, capaz de fazer o fiel perceber os vestígios de uma realidade invisível ${ }^{37}$. Como bem disse Schmitt, a imagem:

'presentifica', sob as aparências do antropomorfo e do familiar, o invisível no visível, Deus no homem, o ausente no presente, o passado ou o futuro no atual. Ela reitera assim, à sua maneira, o mistério da Encarnação, pois dá presença, identidade, matéria e corpo àquilo que é transcendente e inacessível. ${ }^{38}$

Percebemos assim o quão complexo é o nosso objeto de estudo, e porque sua adequada compreensão depende da análise de aspectos relativos às suas condições de produção, suas relações com o espaço físico ao qual foram designadas, seus papéis nas práticas religiosas, suas funções dentro do ritual católico, e sua recepção pelos espectadores. Com efeito, como propõe Schmitt, temos um duplo desafio ao analisar nosso conjunto de imagens: devemos compreendê-las tanto como "arte em sua especificidade e [como objeto de culto] em sua relação dinâmica com a sociedade que a produziu"39. Reiteramos, assim, que em nossa dissertação abordaremos a interdependência entre as múltiplas funcionalidades das imagens religiosas e a linguagem artística, o que por sua vez vai se modificando no decorrer do processo histórico. Estas modificações de caráter formal acabam conferindo algumas

que me has hecho" e Juan respondeu "Seños, lo que quiero que me deis son los sufrimientos que tenga que soportar por vos y que yo sea despreciado y considerado como insignificante cosa". STOICHITA, Victor I. El ojo místico. Pintura y vision religiosa en el Siglo de Oro español, 1996, p. 59.

${ }^{36}$ BELTING, Hans. Semelhança e Presença: a história da imagem antes da era da arte, 2010, p. 7.

${ }^{37}$ Por causa da Queda, o homem estaria vivendo num estado de dissemelhança de Deus, e, uma das potencias das imagens religiosas é justamente a capacidade de tornar sensível o que é transcendente, e não representar uma realidade física. SCHMITT, Jean-Claude. O corpo das imagens. Ensaios sobre a cultura visual na Idade Média, 2007, pp. 13-14.

38 SCHIMITT, Jean-Claude. Imagem, in: Le Goff, Jacques e SCHMITT, Jean-Claude. Dicionário temático do Ocidente Medieval. São Paulo: Edusc, 2006, p. 595.

39 SCHMITT, Jean-Claude. O corpo das imagens. Ensaios sobre a cultura visual na Idade Média, 2007, p. 33. 
características típicas às imagens de um determinado momento histórico, e que muitas vezes recebem denominações estilísticas, como góticas, clássicas ou barrocas.

No que tange às imagens analisadas, devemos levar em conta dois fenômenos históricos que acreditamos ser relevantes para a configuração de suas qualidades materiais e cultuais. Primeiramente, ocorreu um processo de desenvolvimento das coleções de arte, o que Victor Stoichita apontou como a tomada de consciência da “imagem pela imagem”, responsável por um novo olhar para as pinturas ${ }^{40}$. Outro fator decisivo para a configuração das imagens sagradas foi a Reforma Protestante e a sua concepção de idolatria. Nesse sentido, autores como Hans Belting dizem que este é o momento em que "a crise da antiga imagem e o surgimento de um novo conceito de arte são interdependentes [...]”. Para Belting, o que os reformadores rejeitavam da imagem religiosa era que "desde há muito, [a imagem já havia] perdido a velha substância da revelação pictórica não mediada", em um "processo pelo qual a imagem de culto medieval se tornou a obra de arte moderna". No entanto, discordamos em certa medida de suas declarações, pois é certo que na esfera católica as imagens permaneceram como símbolos materiais de sua $\mathrm{fe}^{41}$, e no domínio estrito da imagem religiosa, observamos a continuidade das diversas funcionalidades que elas há muito vinham exercendo para a fé cristã, agora católica ${ }^{42}$. O que verificamos é a conformação de um processo histórico em que as conjugações de ideias, ações e espaços levaram à adequação das imagens religiosas à sua realidade, e não ao seu desaparecimento.

Não obstante, para a Igreja romana as imagens cristãs acabaram atuando como importante instrumento de manutenção e propagação da fé ${ }^{43}$. Além do decreto Sobre a inovação, a veneração e as relíquias dos santos, e sobre as imagens sagradas de 1563, fruto do Concilio de Trento, foram elaborados tratados e constituições sinodais como instrumentos de controle de aplicação do decreto, com a intenção de instruir os clérigos locais sobre o uso lícito das imagens sagradas. A Igreja contou ainda com o auxílio das visitas inquisitoriais para fiscalizar os cultos e a produção de novas imagens.

\footnotetext{
40 STOICHITA, Victor. L'instauration du tableau. Métapeinture à l'aube des tempes modernes, 1999, p. 134.

${ }^{41}$ ESPESO PEREDA, Felipe. Las imágenes de la discordia: política y poética de la imagen sagrada en la España del cuatrocientos. Madrid: Marcial Pons, 2007. Edição Kindle. Posição 65-5673.

${ }^{42}$ CHRISTIN, Olivier. Du culte chrétien au culte de l'arte : la transformation du statut de l'image (XveXVIIIe siècles). Revue d'histoire moderne et contemporaine. Berlin, 2002/3 - no 49-3, p. 188; BASCHET, Jérôme. A civilização feudal: do ano mil à colonização da América, 2006, pp. 33-45.

${ }^{43}$ SERRÃO, Vitor. Entre a Maneira Moderna e a Idéia de decoro. In: PAULINO, Francisco Faria. A pintura maneirista em Portugal: arte no tempo de Camões. Lisboa: CNCDP, 1995, pp. 16-57.
} 
Em paralelo às normas institucionais, as práticas devocionais - que igualmente se modificam no processo histórico - também foram responsáveis pelas transformações na figuração religiosa ${ }^{44}$. As visões, os próprios relatos e as hagiografias, como as de Santa Teresa de Ávila ${ }^{45}$, de Santo Inácio de Loyola e de outros santos contemporâneos, foram fundamentais nesse contexto religioso. Como bem observou Victor Stoichita, "a assimilação das experiências místicas pelas autoridades religiosas esteve acompanhada de um processo de cristalização de soluções figurativas aptas para representar (e difundir) visualmente a experiência visionária"46.

Como parte de uma campanha de difusão das experiências sagradas e da afirmação do culto aos objetos sagrados, a Igreja de Roma incentivou a produção de pinturas que narravam visões, milagres e também os pecados, intencionando persuadir o espectador e propagar a fé ${ }^{47}$.

\subsection{Concílio de Trento, Sínodos e Tratados: as imagens sagradas após a Reforma Protestante}

O Concílio de Trento (de 1545 a 1549; de 1551 a 1552 e de 1562 a 1563) a princípio voltava-se para a problemática das Reformas Protestantes ${ }^{48}$ e sua expansão. “A reforma interna da Igreja Católica também se situa no processo de modernização e

\footnotetext{
${ }^{44}$ A partir do século XIV o tema da salvação começa e ser colocado em termos individuais, e a devoção privada se inscreve no centro das práticas religiosas. A busca por um contato pessoal com Deus, a imitação de Cristo e as orações endereçadas à Virgem e aos santos são intermediadas pela contemplação das imagens. Esta devoção pode ser definida como um comportamento não somente ritual, mas também afetivo, que se articula com o imaginário religioso. DAUMAS, Maurice. Images et societés dans l'Europe modern: 15e-18e sièle. Paris: Armand Colin, 2000, p. 69. Ver também: BELTING, Hans. Semelhança e Presença: a história da imagem antes da era da arte, 2010, pp. 410-419.

${ }^{45}$ Por vezes, afirmou que a imagem material foi um meio de ultrapassar a realidade física. ÁVILA, Teresa de. Cuentas de consciencia, apud: STOICHITA, Victor I. El ojo místico. Pintura y vision religiosa en el Siglo de Oro español, 1996, p. 48.

${ }^{46}$ STOICHITA, Victor I. El ojo místico. Pintura y vision religiosa en el Siglo de Oro español, 1996, p. 12.

${ }^{47}$ STOICHITA, Victor I. El ojo místico. Pintura y vision religiosa en el Siglo de Oro español, 1996, p. 12.

${ }^{48}$ As premissas teológicas de Lutero foram influenciadas por uma leitura pessimista de Santo Agostinho, da natureza decaída do homem, que por consequência rejeitando o tomismo e o humanismo cuja essência da teologia foi a Justificação pela fé. Esta doutrina de justificação pela fé desqualifica a importância da Igreja Instituição visível - não é necessário um intermediário entre o fiel e Deus e "... a decorrência de foi uma teologia inteiramente nova, com base na qual ele pôde atacar o papado e toda a Igreja Católica", SKINNER, Quentin. As fundações do pensamento político moderno. São Paulo: Companhia das Letras, 2009, p. 290.
} 
de formação das novas Igrejas territoriais: é uma resposta às exigências impostas pelas transformações da cultura e da sociedade..." ${ }^{\text {49 }}$. Ou seja, a convocação do Concílio não foi apenas uma resposta à cisão da cristandade Ocidental, mas também uma necessidade interna à Igreja, para solucionar problemas relacionados às ações de seus membros, ao distanciamento social dos clérigos e ao enriquecimento desproporcional à realidade de muitas localidades ${ }^{50}$.

Desde o começo, o Concílio optou por enfrentar questões disciplinares e doutrinais. As prioridades discutidas nas reuniões conciliares foram as perdas territoriais europeias para a Reforma Protestante e as questões doutrinárias como sacramentos (com ênfase na confíssão ${ }^{51}$ ), as indulgências, a função do purgatório, o culto aos santos e à Virgem e às suas imagens, e o catecismo (o cunho teológico do catecismo tridentino e a Vulgata), deixando de fora o tema da relação da Graça com o Livre Arbítrio ${ }^{52}$. Já a aplicação das determinações do Concílio nos territórios além de Roma ocorreu por meio de sínodos diocesanos e concílios provinciais, adaptando-se, assim, às particularidades e necessidades religiosas de cada diocese.

O Imperador Carlos V (1500-1558) ${ }^{53}$ fez questão de envolver-se diretamente, e até mesmo incitou a convocação do Concílio, e seguindo as mesmas diretrizes Felipe II (1527-1598) garantiu a atuação da monarquia hispânica sobre as decisões conciliares. A despeito das polêmicas geradas pelas tentativas insistentes de exercer poder sobre o papado, que foram interrompidas pela bula papal Benedictus Deus, em julho de 1564,

\footnotetext{
49 PRODI, Paolo. Uma história da justiça do pluralismo dos foros ao dualismo moderno entre consciência e direito. São Paulo: Martins Fontes. 2005, p. 291.

${ }^{50}$ FRANCO LLOPIS, Francisco de Borja. Espiritualidade, Reformas y Arte en Valencia (1545-1609). Tese (Doutorado em História da Arte) História, Teoria i Critica de les Arts - Universidade de Barcelona, 2007, p. 55.

${ }^{51}$ A importância delegada à confíssão, que agiu como resposta a premissa luterana de justificação pela fé. Não é um confessar e arrepender-se dos pecados, mas sim, examinar tais ações e refletir e definir as ações posteriores."Constituiu-se como a possibilidade de estender a todos a salvação eterna..." AGNOLIN, Adone. Jesuítas e selvagens: a negociação da fé no encontro catequético-ritual americano-tupi (séculos XVI-XVII). São Paulo: Humanitas, 2005, p. 179.

52 "En su VI sesión (13 de enero de 1547), el concilio aborda los problemas de la modalidad de salvación teniendo como principio la cuestión de la fe. Aunque no era inalcanzable, la redención exigía el aprendizaje de las verdades de la fe. Una de las soluciones era que el hombre pudiera beneficiarse de la condescendencia divina, medio que le garantizaba el camino hacia la salvación. Sin embargo, nadie podía saber si había obtenido la gracia de Dios". GARCIA GARRIDO, Manuela Águeda. La imagen Predicada. La virtud como camino hacía la salvación en los retratos de Francisco Pacheco. Etiopica: Revista de Letras Renacentista, ${ }^{\circ}$ 2, Huelva: Universidad de Huelva, 2006, p. 173.

${ }^{53}$ Carlos V do Sacro Império Romano Germânico e Carlos I de Espanha.
} 
eliminado a atuação do poder temporal nos assuntos conciliares $^{54}$, a monarquia espanhola de pronto acatou os decretos tridentinos, e Felipe II teria assegurado seguir as resoluções de Trento como lei. Desta feita, um processo de institucionalização das determinações contrarreformistas permeou os aspectos sociais, políticos e culturais, e em consequência a religião passou a ser o substrato ideológico que determinou os valores e a conduta social da Espanha do século de ouro ${ }^{55}$.

Sobre a invocação, a veneração e as relíquias dos santos, e sobre as imagens sagradas, de 1563

Em janeiro de 1563, o Cardeal de Lorraine, Carlos Guise (1524-1574), apresenta aos conciliares um memorando com 32 dois artigos que ele acreditava serem fundamentais e deveriam ser discutidos nas sessões do Concílio. Dentre estes artigos, o de número 29 expõe a crise iconoclasta que atingia a Europa:

Porque iconoclastas têm surgido em nossos tempos, homens que acreditam que as imagens devam ser destruídas, o que resultou em graves perturbações da ordem pública em muitos lugares, o Concílio deve tomar medidas para garantir que os fiéis sejam devidamente instruídos na doutrina da Igreja sobre a veneração de imagens. O Concílio deverá igualmente tomar medidas para eliminar os abusos e práticas supersticiosas que cresceram a esse respeito. Disposições semelhantes devem ser tomadas para as indulgências, as peregrinações, as relíquias dos santos e as chamadas irmandades $\left[\right.$ tradução nossa.$^{56}$

Por influência deste cardeal, como uma resposta às investidas iconoclastas dos luteranos e calvinistas, realizou-se a sessão XXV, entre 3 e 4 de dezembro de 1563, do Concílio tridentino. Fruto desta sessão foi o documento De invocatione veneratione, et Reliquiis, Sactorum, et sacris imaginibus, que afirma ser bom e útil "o culto às relíquias

\footnotetext{
${ }^{54}$ FRANCO LLOPIS, Francisco de Borja Franco. Espiritualidade, Reformas y Arte en Valencia (1545-1609). 2007, pp. 57-59.

${ }^{55}$ VELANDIA ONOFRE, Darío. Hacia una teología de la imagen. Mística, oratória y pintura en la España del Siglo de Oro, 2014, p 36.

${ }^{56}$ Because iconoclasts have arisen in our times, men who believe images must be destroyed, which has resulted in grave public disturbances in many places, the council must take measures to ensure that the faithful are properly instructed in church teaching regarding the veneration of images. The council should likewise take measures to eliminate the abuses and superstitious practices that have grown up in that regard. Similar provisions should be made for indulgences, pilgrimages, the relics of the saints and the socalled brotherhoods. Apud: O'MALLEY, John. Art, Trent and Michelangelo's 'last judgment'. In: Religions, 2012, 3, p.350.
} 
e o uso legítimo das imagens", mantendo as conclusões elaboradas no Segundo Concílio de Niceia:

deve-se ter e conservar, especialmente nos templos, imagens de Cristo, da Virgem mãe de Deus e outros Santos e a elas se deve conferir a devida honra e veneração, não por se acreditar que haja nelas alguma divindade ou virtude em razão da qual deveriam ser cultuadas, ou para obter algo delas, ou porque se deva depositar confiança nas imagens, como outrora ocorria com os gentios, que colocavam suas esperanças nos ídolos, mas porque a honra que é a elas dirigida volta-se para os modelos que representam, de tal forma que, através das imagens que beijamos e diante das quais descobrimos a cabeça e nos prosternamos, adoramos a Cristo e veneramos os santos cuja aparência elas reproduzem. Isso é o que, através dos decretos dos concílios, sobretudo o segundo sínodo de Nicéia, estabeleceu-se contra os que atacavam as imagens ${ }^{57}$

O Concílio, portanto, reafirmou a função das imagens religiosas no culto católico e ao mesmo tempo alertou sobre os perigos da idolatria. Pois, segundo Palma Martínez, as acusações baseadas nas Escrituras que formaram o alicerce dos preceitos protestantes contra o uso das imagens religiosas foram as mesmas apresentadas pelos iconoclastas dos séculos VII e VIII em Bizâncio. Logo, no Concílio de Trento, os teólogos se limitaram a "recoger y actualizar lo declarado en el de Niceia respecto a la imagen, saparándola de la definición de ídolo" ${ }^{\text {"58. }}$.

Porém, segundo Felipe Espeso Pereda no artigo Cultures de la representation dans l'Espagne de la Réforme Catholique, o Concílio não conseguiu elaborar uma conclusão a respeito da forma adequada de culto à imagem. Para Espeso Pereda, de modo calculado, o decreto não resolveu a ambiguidade das imagens religiosas, de representação do ausente ou de fazer presente o ausente. ${ }^{59}$

A base do decreto tridentino esteve na censura e na necessidade de eliminação das imagens dogmaticamente errôneas e lascivas, evitando o desvio de culto. Desta forma, somente sob a aprovação de um bispo seria permitido colocar ou mandar colocar uma nova imagem em uma igreja ou em outro lugar. Mas devemos compreender que

\footnotetext{
${ }^{57}$ Apud: LICHTENSTEIN, Jacqueline. A pintura: textos essenciais. Vol. 2: A teologia da imagem e o estauto da pintura, 2008, pp. 67-68.

${ }^{58}$ A distinção está em que a imagem a representação de algo real e verdadeiro, já o ídolo seria a figuração da imaginação humana. MARTÍNEZ-BURGOS GARCIA, Palma. Ídolos e Imágenes: la controvérsia del arte religioso en el siglo XVI español. Valladolid: Universidad Valladolid/Caja Salamanca, 1990, p. 39.

${ }^{59}$ ESPESO PEREDA, Felipe. Cultures de la representation dans l'Espagne de la Réforme Catholique. In: Perspective. Paris, 2009, 2, pp. 291-292.
} 
estas determinações não efetivaram mudanças radicais na relação dos fiéis com as imagens religiosas; antes, devemos compreendê-las em um longo processo anterior ao Concílio de Trento ${ }^{60}$ e que se edificou no decorrer dos anos seguintes. Aos poucos a Igreja criou instrumentos para o controle e aplicação dos decretos tridentinos, como Sínodos Diocesanos, Concílios Provinciais e Tratados Artísticos. Os Sínodos formam os primeiros meios encontrados para a efetivação dos decretos, as Constituições emanadas dos Sínodos "transformaram-se no melhor testemunho, na fonte directa, quase única, de conhecer e avaliar a eficácia da aplicação dos decretos conciliares em todos os domínios da vida eclesiástica, religiosa, e naturalmente, artística."61 . Vitor Serrão chama atenção para o fato de que, a despeito das diretivas tridentinas terem sido cerceadoras, elas também foram "estimuladora de um novo espírito de solenidade e eficiência dos resultados artísticos..."62.

Já sobre as reações consideradas heréticas de desrespeito ao culto às imagens, cabe lembrar que no mundo ibérico a penetração das ideias luteranas e calvinistas teve pouco impacto, e o alvo da vigilância tridentina, assim como já vinha ocorrendo com a Inquisição, permaneceu sendo os cristãos-novos (marranos e mouriscos) e os resistentes humanistas entusiastas de Erasmo ${ }^{63}$.

\section{Concílios Provinciais e Sinodais de Toledo}

No que diz respeito ao culto às imagens e objetos religiosos, o Concílio de Trento confiou aos bispos o cumprimento e a adaptação das normativas estabelecidas. Foram os Concílios Provinciais e os Sínodos Diocesanos responsáveis por adaptar tais decisões para as mais distintas localidades, como o caso do Arcebispado de Toledo.

\footnotetext{
${ }^{60}$ Os debates a respeito das imagens religiosas são anteriores ao Concílio de Niceia, mas suas proposições foram preceitos das determinações tridentinas. Ver FRANCO LLOPIS, Francisco de Borja Franco. Espiritualidade, Reformas y Arte en Valencia (1545-1609), 2007, pp. 62-67

${ }^{61}$ MARTINS, Fausto Sanches. O conceito de "Nihil Inhonestum" nos Tratados Artísticos Pós-tridentinos. In: Estudos em homenagem a Luiz António de Oliveira Ramos. Porto: Universidade do Porto, 2004, p. 716.

${ }^{62}$ SERRÃO, Vitor, Impactos do Concílio de Trento na Arte Portuguesa entre o Maneirismo e o Barroco (1563-1750). In: GOUVEIA, António Camões; BARBOSA, David Sampaio Barbosa; PAIVA, José Pedro. O Concílio de Trento em Portugal e nas suas Conquistas: olhares novos. Lisboa: UCP, 2014, p. 103

${ }_{63}$ Ver: MENDES, Antônio Rosa. A vida Cultural. In: MAGALHÃES, Joaquim Romero (coord.).
} História de Portugal no alvorecer da modernidade. Vol. 3. Coimbra: Estampa, 1993. 
Ao findar o Concílio de Trento, Felipe II apressadamente acolheu suas decisões e em 1565 enviou correspondência aos Prelados recomendando a convocação de Concílios Provinciais nas respectivas províncias eclesiásticas ${ }^{64}$. É importante lembrar que os Concílios Provinciais são as reuniões dos bispos pertencentes a uma mesma província eclesiástica, convocadas pelo seu metropolitano juntamente com os representantes de cada diocese, e foram prescritas pelo decreto da segunda sessão XXIV do Concílio de Trento em $1563^{65}$.

Os Concílios Provinciais e os Sínodos Diocesanos, segundo Angél Fernandez, são sempre intimamente unidos. O Concilio Provincial, de maneira mais geral

toma consciencia de su ser y realidad e impulsa el cumplimiento y la concretización histórica de los contenidos teológicos y decretos disciplinares a través del otro, más particular, en las diócesis. ${ }^{66}$

Foram os cinco textos das Constituições Sinodais do Arcebispado de Toledo que compilaram as decisões a respeito das imagens religiosas e as aplicaram nos séculos XVI e XVII: 1583, 1601, 1622, 1660, 1682. A primeira (de 1583), em seu decreto 67, estabeleceu as bases das diretrizes a respeito das imagens religiosas, e as seguintes apenas reformularam-na em alguns pontos. Nela se estabeleceu a proibição de pintar imagens sem a supervisão de um eclesiástico e que as pinturas já existentes nas igrejas deveriam ser examinadas à luz dos novos ordenamentos contrarreformistas; estes eclesiásticos também deveriam atentar-se à decência das esculturas (imagens de vestir $^{67}$. E na Constituição Sinodal de 1601 surge a preocupação com os novos milagres a as novas relíquias, sem a aprovação de um eclesiástico: "no se admitan nuevos milagros, ni si reciban nuevas relíquias", para combater todas as superstições e abusos derivados da proliferação incontrolada de narrativas de milagres. As manifestações místicas novas só poderiam ser retratadas pictoricamente quando já canonicamente recebidas por Roma e incorporadas aos rituais católicos. ${ }^{68}$

\footnotetext{
${ }^{64}$ COLLADO FERNÁNDEZ, Ángel. Historia de la Iglesia en la España. Edad Moderna. Toledo: I. T. San Idelfonso, 2007. p 210-211

${ }^{65}$ COLLADO FERNÁNDEZ, Ángel. Historia de la Iglesia en la España. Edad Moderna, 2007, p 210. ${ }^{66}$ COLLADO FERNÁNDEZ, Ángel. Historia de la Iglesia en la España. Edad Moderna, 2007, p. 212.

${ }^{67}$ SUÁREZ QUEVEDO, Diego. De imagen y reliquia sacras. Su regulación en las constituciones sinodales postridentinas del arzobispado de Toledo. Anales de Historia del Arte, vol 8 Madrid: Universidad Complutense, 1998, p 264.

68 SUÁREZ QUEVEDO, Diego. De imagen y reliquia sacras. Su regulación en las constituciones sinodales postridentinas del arzobispado de Toledo, 1998, p 267.
} 
Na Constituição de 1622, o artigo com o título De Imaginibus \& reliquijs Sanctorum $^{69}$ é praticamente uma cópia das determinações de 1601, mantendo a proibição de pintar imagens de novos milagres que não tivessem sido confirmados pelas autoridades:

Esta determinado por decreto del Sacro Concilio de Trento, que no se admitan nuevos milagros ni se reciban nuevas reliquias, sino fueren conocidos $\mathrm{y}$ aprobados por el Ordinario: porque cesen todas supersticiones y abusos, y otros inconvenientes. $\mathrm{Y}$ que aprobados y conocidamente recibidos, los fieles Christianos debidamente den honor y veneración a las santas reliquias, y movidos de los milagros que nuestro Seños haze por los Santos, y de memoria de sus santas vidas y martirio, con santo zelo los imiten, y humilmente los invoque: y componiéndose en vida y costumbres, den gracias a nuestro Señor. Por ende S.S.A. ordenamos y mandamos que en ningunas Yglesias, Monasterios, ni Capillas, ni otros lugares pios deste nuestro Arçobispado, se publiquen, ni admitan nuevos milagros, ni se reciban nuevas reliquias, que no fueren reconocidos y aprobados por Nos, o por nuestros predecesores de buena memoria, o nuestros sucesores, en la forma que manda el Decreto del dicho Santo Concilio. Y que la información que sobre los dichos milagros se hubiere de hazer, sea de oficio, y para elle no se admitan, ni reciban testigos presentados por persona alguna. Y assi mismo mandamos, que no pongan en parte alguna al redor de las Imagines mortajas, letreros, ni insignias de milagros, sin que ayan precedidos las dichas informaciones, y aprobación. Y mandamos, que las Yglesias no se pongan tablas de pinturas profanas. ${ }^{70}$

Devido à insistência nas aprovações para os novos milagres, notamos que tais restrições eram tidas como importantes para conter os abusos e os excessos, em uma clara preocupação com as devoções que se aproximavam da idolatria.

Apesar da preocupação com as superstições e os abusos que muitos fiéis apresentavam ao cultuar as imagens religiosas, as Constituições Sinodais não formularam uma determinação que abrangesse as questões relacionadas à forma correta de culto e à essência das imagens religiosas, se elas seriam ou não capaz de atuar como um intermediário entre o mundo celeste e o terrestre.

\footnotetext{
69 TOLEDO (Diócesis). Sínodo. Constituciones sinodales del Smo. ... don Fernando, Cardenal Infante, administrador perpetuo del Arcobispado de Toledo, 1622. fol. 9v-11r.

70 TOLEDO (Diócesis). Sínodo. Constituciones sinodales del Smo. ... don Fernando, Cardenal Infante, administrador perpetuo del Arcobispado de Toledo. fl. 10v-11r.
} 


\section{Tratados sobre as imagens religiosas}

Como vimos, as recomendações do Concílio de Trento sobre os objetos visuais foram breves, de maneira que foi necessária a mediação de teólogos que elaboraram tratados para explicar os decretos conciliares e assim orientar não só as igrejas como também os artistas responsáveis pela produção das imagens religiosas. Destarte, formou-se um grupo de eclesiásticos eruditos que, motivados pelos projetos tridentinos, elaboraram "um corpo doutrinal homogêneo que sublinha as bases sólidas em que devia assentar a iconografia cristã, ${ }^{, 71}$. Porém, não foram novos conceitos artísticos ou estéticos que estes tratados assinalaram, mas sim "a reelaboração de uma ideologia imperante nos séculos anteriores e que agora é recolhida e recodificada" ${ }^{, 72}$, como veremos a seguir.

Preocupado com o controle de práticas supersticiosas relativas ao uso de imagens sagradas, o professor de teologia e censor de livros holandês Jan Meulen (Johannes Molanus, 1533-1585) escreveu De Picturis et imaginibus sacris liber unus (1570), o primeiro tratado eclesiástico que pretendia esclarecer as decisões de Trento sobre as imagens religiosas ${ }^{73}$. Além de tratar de questões religiosas, nesta obra ele também comenta outros temas não eclesiásticos, demonstrando seu conhecimento sobre estética e de autores como Vitrúvio, Alciato, Alberte ${ }^{74}$. No tratado, o censor propõe instaurar um controle rígido tanto da forma quanto do conteúdo das imagens religiosas. Molanus inicia seu texto avisando que tratara de dois assuntos, um sobre os ataques iconoclastas e o outro sobre o mau uso das imagens sagradas ${ }^{75}$ :

duas questões sobre as imagens devem ser tratadas. Uma contra os iconoclastas ou iconomaques, perfídia defendida e mantida. Outro assunto é sobre o uso ilegítimo, dos abusos ou ignorância católica, que deve ser corrigido e evitado.

\footnotetext{
${ }^{71}$ MARTINS, Fausto Sanches. O conceito de "Nihil Inhonestum" nos Tratados Artísticos Pós-tridentinos, 2004, p. 717.

72 FRANCO LLOPIS, Francisco de Borja. Espiritualidade, Reformas y Arte en Valencia (1545-1609), 2007, p. 130.

${ }^{73}$ Em 1564, um ano após a final do Concílio, Gilio de Fabriano publica o Dialogo degli Erroni d' pitorri, mas trata apenas da questão da nudez e não do decreto tridentino. FREEDBERG, David. Johannes Molanus on provocative paintings. In: Journal of the Warburg and Courtauld Institutes, Londres: Warburg Institutes, 1971, p. 229.

${ }^{74}$ FREEDBERG, David. Johannes Molanus on provocative paintings, 1971, p. 232.

${ }^{75}$ MOLANUS, Johannes. De Picturis et imaginibus sacris líber unus. 1570, Prefácio, p. 12.
} 
Tanto para o cuidado amoroso que desejou o Sacrossanto Concílio de Trento $[\text { tradução nossa }]^{76}$

A obra está dividida em quatro livros, e no primeiro o teólogo faz uma História da Querela das Imagens no Oriente, enfatizando que a Igreja sempre defendeu as imagens religiosas e combateu seus detratores. Em seguida, o autor constrói sua crítica às imagens desonestas e ao excesso de nudez, a partir de seu pressuposto que imagens funcionariam como o livro "dos leigos e iletrados", concluindo que se existia a censura para livros também deveria haver para as imagens ${ }^{77}$. Molanus sugere mesmo um controle por "autoridade civil" do mercado de pinturas, e no seu texto o teólogo também discorre sobre a importância da pintura como gênero histórico (sagrado) ${ }^{78}$.

O segundo tratado que iremos comentar é o de Gabriel Paleotti (1522-1597), que participou do Concilio de Trento como conselheiro dos legados romanos da corte pontifical e depois foi nomeado membro da nova congregação do Concílio. Em 1565 ele se tornou cardeal e no ano seguinte bispo da cidade de Bolonha. Para ele, a pintura poderia servir como ferramenta pedagógica para o ensino e a propagação da fé católica; no entanto, para tal fim seria necessário conhecer e analisar todos os recursos das artes representativas e estar atento às normas conciliares. Com o intuito de explicar os decretos tridentinos a respeito da iconografia cristã, elaborou o tratado Discorso intorno alle imagini sacre et profane em $1582^{79}$, no qual afirma que as representações das histórias sagradas deveriam ser estritamente fiéis aos textos bíblicos para evitar a confusão dos iletrados. Sob a influência dos estudos dos humanistas, Paleotti acreditava que o conhecimento renascentista da natureza, da história e dos homens deveria contribuir para a elaboração das iconografias religiosas. Nesse ponto, ele recorre ao

\footnotetext{
76 "De sacris imaginibus atque pictures duo potissimum tractanda sunt. Earum enim legitimus vsus contra iconomachorum, siue iconoclastarum, perfidiam defendendus est, e retinendus. Earundem quoque vsus illegitimus, siue abusus, contra Catholicorum quorüdam negligentiam, vel ignorantia, corrigendus est, \& vitandus. Vtriusque enim curam diligentem habere voluit sacrosanta Synodus Tridentina." MOLANUS, Johannes. De Picturis et imaginibus sacris líber unus. 1570, Prefácio, p. 12.

${ }^{77}$ Citando Horácio, ele afirma que as pinturas teriam um efeito muito mais poderoso dobre o espectador, e por este motivo deveriam ter um rigoroso controle. FREEDBERG, David. Johannes Molanus on provocative paintings, 1971, p. 234.

78 “.... Igreja venera com todas as sortes de devoção as lutas dos mártires e as vidas dos Pais solidamente escritas, ela acolhe, com o mesmo espírito pio, essas mesmas histórias expressas em pinturas...”

${ }^{79}$ Para a elaboração de seu tratado Paleotti teve acesso à obra de seu amigo Bispo de Milão Carlo Barromeu sobre a arquitetura pós-Trento; leu o tratado de Jan Meulen De Picturis et imaginibus, consultou as Vita de Giorgio Vasari, além de discutir o assunto com váiros colegas filósofos, teólogos, pintores etc. MARTINS, Fausto Sanches. O conceito de "Nihil Inhonestum" nos Tratados Artísticos Póstridentinos, 2004. p. 721.
} 
juízo de imitação, pois no seu entender seria através da mimese que se poderia alcançar um melhor conhecimento da natureza dos homens sem nunca se distanciar da verdade ${ }^{80}$.

Paleotti também alerta para o controle do que deve ser visto e para a importância de uma autoridade legítima que, partindo do que fora estabelecido no Concílio de Trento, autorize a reprodução de cenas sagradas. O cardeal lembra que as narrativas sagradas nem sempre são de fácil compreensão, e que o artífice não pode ter muita liberdade em matérias duvidosas, devendo sempre recorrer a teólogos e eclesiásticos, pois ao artesão cabe apenas imitar o que os olhos veem, ou seja, as coisas da natureza. Quanto aos mistérios sagrados, caberia aos mestres na doutrina sagrada decifrá-los. A prudência deve acompanhar o pintor e consequentemente em suas obras eles devem estar em harmonia com o consenso universal dos doutos e as imagens aprovadas pelos santos bispos em suas igrejas, o que é exigido por um conselho prudente, pela experiência e pelo juízo bem estabelecido ${ }^{81}$.

No entanto, para nossa investigação, é de suma importância o capítulo XVI do livro primeiro, Quali si chiamino imagini sacre, pois foi nele que Paleotti definiu o que são as imagens sagradas, através de oito apontamentos, sendo que no quinto estão as imagens milagrosas, que seriam capazes de interferir no mundo físico ${ }^{82}$. Neste ponto, o cardeal toca em um tema-chave muito pouco explorado pela ortodoxia católica, pois se receava que a aceitação deste tipo de culto pudesse conduzir o fiel à idolatria e também justificasse as acusações dos protestantes. Dentre os tratados que analisamos aqui, este foi o único em que encontramos tais afirmações.

O pintor Francisco Pacheco (1564-1644), membro da Academia de Pintura de Sevilha, foi indicado, em 1618, pelo Santo Tribunal de la Inquisición como censor do campo das artes, cumprindo a função de controlador da ortodoxia iconográfica. Como

\footnotetext{
${ }^{80}$ LICHTENSTEIN, Jacqueline. A pintura: textos essenciais. Vol. 2: A teologia da imagem e o estauto da pintura, 2008, pp.75-73; MARTINS, Fausto. O conceito de "Nihil Inhonestum" nos Tratados Artísticos Pós-tridentinos, 2004, pp. 720-722.

${ }^{81}$ Apud: LICHTENSTEIN, Jacqueline. A pintura: textos essenciais. Vol. 2: A teologia da imagem e o estauto da pintura, 2008, pp.79-82.

${ }^{82}$ Quinto, perché Iddio abbia operato manifestamente segni e miracoli in tale imagine, come sappiamo essere accaduto in quella della casa santa di Loreto, trasportandola di così lontano paese et operando di poi tanti miracoli col mezzo di essa, quanti ogni giorno si veggono; il che similmente si dirà delle altre, che si ritrovano in varii luoghi, le quali per opera divina si serano vedute talora con la faccia risplendente, talora gittare vive lagrime dagli occhi o gocciole di sangue, overo fare qualche movimento della persona, come fossero vive, o pure perché in esse si sarà evidentemente riconosciuta la bontà divina, che col mezzo loro avrà risanato in un momento infermi, resa la luce a ciechi e liberato altri da diversi pericoli. PALEOTTI, Gabriel. Discorso intorno alle imagini sacre et profane. Livro I, cap. XVI, 1582.
} 
pintor erudito, dedicou-se à elaboração de pinturas religiosas, sempre estudando e seguindo as determinações do Concílio e os tratadistas pós-Trento. Além disto, também fora estudioso dos tratadistas e artistas renascentistas como Alberti e Vasari, o que lhe proporcionou conhecimento profundo e base para a elaboração do Arte de la Pintura de 1638. Pacheco viveu cercado por uma sociedade de eruditos, aristocratas e eclesiásticos, e, na Academia de Sevilha, chegou a ser diretor.

$\mathrm{Na}$ Arte de la pintura, Pacheco retoma os mais importantes tratados italianos de pintura e textos da antiguidade e os combina às orientações dos decretos tridentinos. Nesta obra, o pintor discute a antiguidade e superioridade da pintura diante da escultura, ilustrando tais argumentos com santos que seriam pintores; trata da questão do decoro; e por último apresenta um guia para orientar pinturas na ortodoxia, exemplificando como representar alguns temas como a Santíssima Trindade e alguns Santos. ${ }^{83}$

Ademais, assim como os outros tratadistas, Pacheco aborda o tema do conhecimento por meio da observação de imagens sacras e das obrigações do pintor que deve imitar a Deus, como explica o trecho que segue:

O altíssimo Deus é soberano artífice em fazer santos e quer e ordena que lhes dê particular reverência e adoração. Os pintores católicos o imitam, fazendo imagens dos mesmos santos e de sua divina majestade. E, ainda que seja infinita a diferença que há entre o Criador e a criatura, quase igualou-se (ó soberana alteza e honra da pintura!) na veneração e respeito e adoração ao santo a quem fez sua majestade à imagem que, a sua imitação, fez o pintor $^{84}$

Entre o decreto do Concílio de Trento, as constituições sinodais e esses poucos tratados analisados, podemos perceber alguns pontos em comum. Havia uma nítida convergência no que tange à questão da utilidade do uso das imagens como ferramenta para a conversão e propagação da fé, e da função das imagens sagradas como alternativa aos textos sagrados para os iletrados, além da necessidade de se controlar tanto o trabalho do artista como o que seria visto pelo fiel, pois nada poderia dar margem a dúvidas sobre a ortodoxia ou levar à superstição ou idolatria, daí a grande preocupação com a fidelidade à história sagrada.

\footnotetext{
${ }^{83}$ LICHTENSTEIN, Jacqueline. A pintura: textos essenciais. Vol. 2: A teologia da imagem e o estauto da pintura, 2008, pp.83-84; MARTINS, Fausto Sanches. O conceito de "Nihil Inhonestum" nos Tratados Artísticos Pós-tridentinos, 2004, pp. 723-726.

${ }^{84}$ Apud: LICHTENSTEIN, Jacqueline. A pintura: textos essenciais. Vol. 2: A teologia da imagem e o estauto da pintura, 2008, p.86.
} 
No entanto, como já havia apontado Espeso, a respeito da essência das imagens religiosas, e da possibilidade delas possuírem a potência de agir no plano terrestre, só encontramos uma frase, no tratado Discorso intorno alle imagini sacre et profane do cardeal Gabriel Paleotti, quando ele afirma existir imagens que podem verter lágrimas e sangue, ou mesmo se movimentar, por meio da bondade divina.

\subsection{As imagens cristãs na Península Ibérica no final da Idade Média e início da} Moderna

No decorrer dos séculos XIII, XIV e XV houve na Península Ibérica uma expansão da importância dos elementos visuais nas práticas devocionais cristãs; e as imagens sagradas, que até então eram restritas aos altares e outros ambientes eclesiásticos, passaram a ser cada vez mais cultuadas também nos espaços domésticos. ${ }^{85}$ Deste modo, houve um aumento do número de imagens religiosas que escapavam ao controle clerical. Além disso, a busca pelo controle territorial fez crescer a necessidade do controle religioso, e por consequência as questões relacionadas ao culto às imagens religiosas se tornaram mais presentes. Um testemunho de que as imagens de culto desempenhavam um papel de grande relevância nas práticas políticas e religiosas cristãs peninsulares são o conjunto de manuscritos iluminados que narram e louvam os feitos milagrosos da Virgem Maria e de suas imagens: as Cantigas de Santa Maria, atribuídas ao rei Afonso $\mathrm{X}^{86}$. Nesta obra podemos perceber a intenção da hierofanização das imagens religiosas, pois a despeito de as Cantigas exaltarem as virtudes da Virgem e narrarem os feitos de Alfonso X, nelas encontramos uma série de cantigas que evocam as virtudes milagrosas das imagens religiosas, tanto da Virgem como de Cristo. Para Espeso Pereda, na Península, embora com algumas reservas, houve uma progressiva

\footnotetext{
${ }^{85}$ ESPESO PEREDA, Felipe. Las imágenes de la discordia: política y poética de la imagen sagrada en la España del cuatrocientos. Madrid: Marcial Pons, 2007. Edição Kindle, Posição 741-5673.

${ }^{86}$ AMARAL, Debora G. P. A Iconoclastia nas Cantigas de Santa Maria. In: XXII ENCONTRO ESTADUAL DE HISTÓRIA ANPHU - SP. Santos: 2014. Anais eletrônicos... 2014, p. 1. Disposnível: http://www.encontro2014.sp.anpuh.org/resources/anais/29/1406772434_ARQUIVO_artigoAnpuhDebora GPA.pdf1.
} 
aceitação das formas de culto às imagens mais apreciadas pelos fiéis, que muitas vezes eram consideradas supersticiosas ou mágicas ${ }^{87}$.

A aceitação de um culto mais fervoroso, que por vezes seria considerado um culto idólatra pela parcela mais resistente da Igreja, ocorreu em grande parte graças à influência das obras de Tomás de Aquino (1224-1274) na religiosidade peninsular. Em sua Suma Teológica (1265-1273), ele aborda a questão do culto aos objetos visuais religiosos, estabelecendo uma hierarquia cultual na qual a imagem de Cristo deve receber a adoração de latria:

...nem ainda hoje, na Igreja, dispõem-se imagens para que se lhes renda um culto de latria, mas com um significado determinado: para que por meio das imagens desse tipo se grave a se fortaleça nas mentes dos homens a fé na excelência dos anjos e santos. Entretanto, com a imagem de Cristo é diferente: a ela, em razão de sua divindade, deve-se latria... ${ }^{88}$

Nas colocações tomistas o culto acontece em um duplo movimento da alma que se dirige à imagem e dela ao seu protótipo, ultrapassando assim a barreira que existiria entre o objeto material e a natureza divina. Segundo Jean Wirth, Tomás de Aquino usa a dualidade da imagem enquanto imagem e coisa revelada, com base numa livre interpretação aristotélica, adaptada à semântica medieval ${ }^{89}$. E Espeso Pereda aponta que as considerações tomistas trouxeram um novo critério semiótico entre a matéria e o objeto da representação. Partindo deste pensamento, na Península, os gestos de tirar o chapéu, acender velas, beijar e ajoelhar-se diante de uma imagem passaram a ser conduta de obrigação social. ${ }^{90}$ Verificamos, pois, a expressiva importância que a imagem devocional vai tomando na cultura cristã ibérica.

Em decorrência destes fatos, assim como em toda a Europa ${ }^{91}$, na Península Ibérica dos séculos XIV e XV aparecem as primeiras críticas moralistas sobre a maneira em que as imagens religiosas estavam sendo cultuadas. Alfonso de Madrigal, bispo de

\footnotetext{
${ }^{87}$ ESPESO PEREDA, Felipe. Las imágenes de la discordia: política y poética de la imagen sagrada en la España del cuatrocientos, 2007, Posição 1286-5673.

${ }^{88}$ Apud: LICHTENSTEIN, Jacqueline. A pintura: textos essenciais. Vol. 2: A teologia da imagem e o estatuto da pintura, 2008, pp. 52-53.

${ }^{89}$ WIRTH, Jean. Faut-il adorer les images? La théorie du culte des images jusqu'au concile de Trente. in: DUPEAUX, Cécile; JEZLER, Peter e WIRTH, Jean. Cataloque de l'exposition: Iconoclasme: vie et mort de l'image médievale. Paris: Le Somogy, 2001, p. 33.

${ }^{90}$ ESPESO PEREDA, Felipe. Las imágenes de la discordia: política y poética de la imagen sagrada en la España del cuatrocientos, 2007, Posição 1286-5673.

91 Como as críticas de John Wycliff (1320-1384).
} 
Ávila (1445-1455), na obra Confessional del Tostado, adverte sobre a proliferação de imagens milagrosas e dos cultos que elas geravam, o que no seu entender era mais próximo ao paganismo que ao culto cristão. O bispo de Ávila considerava gran pecado todas as legendas que conferiam atributos humanos (chorar, sangrar, suar, mover, etc) às imagens religiosas ${ }^{92}$.

E por ende quando toman especial deuocion mas con vna ymagen que con otra pecan [...] y dizen que lloran las ymagines y que echan lagrimas muy dulces y ello es agua y miel que por detras les echan; lo qual seria assaz de consentir en el tienpo que a los ydolos adorauan. E si estos que esto leuantan no hiziessen en ello otro mal: sino que sacassen el dinero avnque es cosa de mal exenplo: empero encima del lo que es lo peor fazen a la gente necia ydolatrar: y a los tales: no solamente se deuia de dar gran castigo mas la tierra no los deuia sufrir. ${ }^{93}$

$\mathrm{Na}$ vertente oposta à de Madrigal podemos citar o franciscano Alonso de Espina (s/d-1496). Para Espeso Pereda, Espina, no Livro III de sua obra Fortalitium Fidei ${ }^{94}$ de 1458, foi o primeiro religioso a elaborar uma teoria sacramental da imagem religiosa na região da Península Ibérica. Para o historiador, Espina conseguiu tal elaboração ponderando dois polos extremos, a teologia e as práticas devocionais, vinculando, à sua maneira, as colocações de João Damasceno e Tomás de Aquino, com as legendas medievais de imagens milagrosas ${ }^{95}$.

Al vincular práctica y teoría, devoción y teología, la forma de culto con el rango sacramental de las imágenes, Espina no sólo obligaba a los teólogos a decir cosas que nunca habían dicho - extrayendo de Santo Tomás conclusiones que no se halla implícitas en sus ideas -, también estaba fabricando un aval para el reconocimiento de que las imágenes, por un lado, representaban la divinidad, pero

\footnotetext{
92 ESPESO PEREDA, Felipe. Las imágenes de la discordia: política y poética de la imagen sagrada en la España del cuatrocientos, 2007, Posição 774-5673. Ver também: MARTINEZ-BURGOS GARCIA, Palma, Ídolos e Imágenes: la controvérsia del arte religioso en el siglo XVI español, 1990, pp. 36-37.

${ }^{33}$ MADRIGAL, Alfonso de. Confesional del Tostado. Apud: CHRISTIAN, Willian A. Images as Beings in Early Modern Spain. In: KASL, Ronda. Sacred Spain: Art and Belief in the Spanish World. Indianapolis: Indianapolis Museum of Art, 2009, p. 96.

${ }^{94}$ Fortalitium Fidei escrito em latim e dividido em cinco livros: o primeiro trata das armas de defesa que os fieis cristãos devem utilizar; o segundo contra as heresias; o terceiro contra os judeus; o quarto contra os sarracenos e o quinto contra o demônio. Apesar de muitos historiadores, classificarem a obra como antissemita, segundo Félix-Tomás López Gurpegui, que traduziu o livro III para o espanhol, o objetivo de Espina seria compor uma persuasão politica e religiosa contra judeus e muçulmanos na Espanha, além de não esconder seu desejo de que uma Inquisição que pudesse atuar com força na Espanha. GURPEGUI, Félix-Tomás López. Introdução. In: Alonso de Espina. Gerra contra los judios. Libro III del Fortalitium Fidei. Já Caro Baroja diz que a obra de Espina é de caráter claramente antijudaico com as clássicas acusações de traidores, assassinos de crianças, usurários, etc. CARO BAROJA, Julio. Los Judíos en la España Moderna y Contemporánea, 1978, pp 418-421.

${ }^{95}$ ESPESO PEREDA, Felipe. Las imágenes de la discordia: política y poética de la imagen sagrada en la España del cuatrocientos, 2007, Posição 1056/9-5673.
} 
incluso, por el otro, podían llegar a contenerla. Nadie antes de él, que sepamos, había defendido nada parecido en la Península Ibérica, los testimonios posteriores son sencillamente innumerables ${ }^{96}$

Um dos eixos do pensamento de Frei Espina foi o pressuposto da contemplação como imagem da Eucaristia ${ }^{97}$. O dogma da transubstanciação, em que Cristo estaria presente na hóstia ${ }^{98}$, foi definido no IV Concílio de Latrão em $1215^{99}$. Desta feita, o franciscano recorreu ao sentido inverso da contemplação visual do sacramento eucarístico para a sacramentação das imagens religiosas ${ }^{100}$. Argumentou que assim como Deus se fez imagem em Cristo, a imagem religiosa não era apenas um caminho para lembrar e seguir os passos de vidas piedosas, mas que ela seria parte da economia global da graça. Ele também apresentou muitos exemplos em que a divindade teria se manifestado por meio do objeto visual, fosse ele pintura ou escultura. ${ }^{101} \mathrm{Um}$ dos exemplos citados é o milagre do Cristo de Beirute ${ }^{102}$.

O milagre do Cristo de Beirute refere-se a um grupo de judeus que açoita e introduz uma lança em um crucifixo, reproduzindo a paixão de Cristo com o intuito de ultrajar a fé cristã. Deste agravo ocorreu o milagre do crucifixo suar e sangrar, levando

\footnotetext{
${ }^{96}$ ESPESO PEREDA, Felipe. Las imágenes de la discordia: política y poética de la imagen sagrada en la España del cuatrocientos, 2007, Posição 1056/9-5673.

${ }^{97}$ Sobre a Eucaristía: “...Y se levanta sobre la cabeza del sacerdote, para ser elevado y adorado por el pueblo...” ESPINA, Alonso de. Fortaleza da Fé, Livro III. Quarta consideracíon. 24/Vigésimocuarto argumento. Edição Kindle, Posição 2142 de 6683; E para a Espanha do final da Idade Média, no que diz respeito à devoção Eucarística, cujos fieis recebiam a hóstia em raras ocasiões, e que por vezes, os devotos acreditavam que o alimento sagrado possuía virtudes magicas e curativas. Tais superstições levavam a muitos fiéis a comparecerem a missa somente para comtemplar a consagração da hóstia, e neste momento, quando o sacerdote elevava o alimento sagrado acima de sua cabeça, os populares podiam contemplá-lo visualmente e assim beneficiar-se de suas virtudes mágicas. O que não passava despercebido por teólogos como Alfonso de Madrigal Tostado. ESPESO PEREDA, Felipe. Las imágenes de la discordia: política y poética de la imagen sagrada en la España del cuatrocientos, 2007, Posição 1122-5673.

98 "El alma de Cristo está unida a su cuerpo, y lo mismo la deidad en la persona del Hijo, y así en las especies de pan y vino, por la fuerza de la conversión o transustanciación, el cuerpo de Cristo con su alma y su deidad, por su concomitancia real e inseparable, están allí: Todo Cristo, entero, verdadero Dios y verdadero hombre, que debe ser adorado con culto de latría." ESPINA, Alonso de. Fortaleza da Fé, Livro III. Quarta consideracíon. 24/Vigésimocuarto argumento. Edição Kindle, Posição 2124 de 6683.

99 Sobre o debate eucarístico medieval, ver a dissertação de mestrado: LUBARINO, Doglas Morais. LUBARINO, Doglas Morais. O Juizo Final e a Missa de São Gregório (MASP 428P): pintura retabular Eucaristica no final da Idade Média. Dissertação (Mestrado em História Social) - FFLCH Departamento de História. UPS. São Paulo 2015. Cap 4.

100 ESPESO PEREDA, Felipe. Las imágenes de la discordia: política y poética de la imagen sagrada en la España del cuatrocientos, 2007, Posição 1122-5673.

${ }^{101}$ ESPESO PEREDA, Felipe. Las imágenes de la discordia: política y poética de la imagen sagrada en la España del cuatrocientos, 2007, Posição 1154-5673.

102 ESPINA, Alonso de. Fortaleza da Fé, Livro III. Decima consideracíon. Quinto admirable. Edição Kindle, Posição 5377- 6683.
} 
este grupo de judeus a se converter ao cristianismo. ${ }^{103}$ Do sangue derramado foram produzidas inúmeras relíquias e o local do acontecimento, a sinagoga dos profanadores, foi convertida em Igreja dedicada ao Salvador. No século IV, esta legenda já era difundida ${ }^{104}$, e compete ressaltar que a narrativa do Cristo de Beirute reverberou na tradição cristã espanhola sob as mais diversas formas, como por meio de supostos ataques iconoclastas e devoção a crucifixos milagrosos, após o século XII.

É interessante notar que na cultura devocional da Espanha dos séculos XV e XVI multiplicaram-se as lendas de crucifixos milagrosos, dentre elas a do Cristo de Burgos. Um relato de viagem de 1465, escrito por um nobre da região da Boêmia, descreve o Cristo de Burgos como milagroso, pois dele cresciam cabelos e unhas, além de apresentar o poder de curar doentes. Afora estes feitos, tal crucifixo adquiriu a fama de o ser o mesmo de Beirute, que teria chegado à Espanha pelo mar. ${ }^{105}$

Os relatos dos milagres do Cristo de Burgos, tanto de sua origem como de suas virtudes sobrenaturais, faziam parte de um contex to espiritual centrado no sofrimento do Cristo, o que se revelou também através da proliferação do culto ao crucifixo para estimular a meditação e que também poderia funcionar como intermediário entre o mundo das coisas naturais e o celeste, e que em alguns casos adquirira fama de possuir potencial milagroso.

Podemos encontrar referências aos inúmeros milagres de crucifixos na obra do dominicano e inquisidor de Valência Jaime Juan de Bleda (1550-1622) ${ }^{106}$, Cuatrocientos milagros, y muchas alabanças de la santa Cruz, impressa em 1600. O autor inicia o livro explicando ao leitor as virtudes da cruz, que são manifestadas em todos os milagres que serão descritos por ele:

\footnotetext{
${ }^{103}$ VARAZZE, Jacopo de. Legenda Aurea: vida de santos. São Paulo: Companhia das Letras, 2003, pp.770-771. A legenda aponta que o crucifixo milagroso teria pertencido a Nicodemus, o fariseu defensor de Cristo que testemunhou a crucificação e a depositar o corpo seu corpo no sepulcro.

${ }^{104}$ Em Bizâncio, no século VIII, durante a crise iconoclasta, a homilia De Passio Imaginis Domini Nostri Jesu Christi, do Bispo São Atanásio de Alexandria, contribuiu favoravelmente à manutenção dos usos da imagem cristã no segundo Concilio de Niceia (787). ARCINIEGA GARCÍA. Luis. La Passio Imaginis y la adaptativa militancia apologética de las imágenes en la Edad Media y Moderna a través del caso Valenciano. Ars Longa. Univercitat de València. 2012, no 21, p. 72,

${ }^{105}$ Ver: MARTÍNEZ MARTÍNEZ, Maria José. El Santo Cristo de Burgos. Contribución al estudio de los Crucifijos articulados españoles. Boletín del Seminario de Estudíos de Arte y Arquiología, BSAA., Valladolid, 2003-2004, tomo 69-70, pp. 207-246.

${ }^{106}$ Jaime Juan de Bleda além de ocupar cargos importantes na hierarquia da Igreja Católica Espanhola, atuou politicamente na corte de Felipe III e em Roma, à favor da expulsão dos mouriscos na Espanha. SÁEZ, Adrián J. Los Cuatrocientos milagros de la Cruz: ¿Libro de cabecera de Calderón?. Atalanta: Revista de las Letras Barrocas. Sevilla, 2013, v.1, nº.1, pp 103-118.
} 
Y por quãto los milagros que Christo hizo en la Cruz se atribuyen a su santissima pasion, y lo que se atribuye a la passion de Christo, se puede atribuyr a la Cruz, pues fue el mayor y mas principal instrumento della: que por eso dizen los santos, que la cruz quita todos los pecados, abre el parayso, es nuestra esperãça, fuete de todas las bendiciones, y causa de todas las gracias. Y demas desto añaden otras muchas excelencias. Por esta causa porne aquí los milagros de la passion de Christo, que son milagros de la Cruz. ${ }^{107}$

O autor compila 400 milagres, descrevendo detalhadamente 170 deles e apenas mencionando os demais ${ }^{108}$. Finaliza a obra com um Tratado sobre a Cruz. A obra não contém somente milagres de crucifixos como objeto material, pois o autor descreve também milagres feitos por Cristo ainda vivo, milagres de santos ou fiéis que fizeram o sinal da cruz, ou mesmo das visões de cruz, como a de Constantino ${ }^{109}$. Nela podemos encontrar relatos em que este objeto se manifesta milagrosamente, como o milagre $106^{110}$, Como mano mucho sangre de la ymagens de um crucifixo que irio um judio con una lança, aqui ele relata a lenda do crucifixo de Beirute, ou o milagre $112^{111}$, Como fue hallado el Crucifixo de Burgos el qual haze muchos milagros. Embora não tenhamos muitas informações historiográficas a respeito desta obra, constatamos que este tipo de publicação nos indica como a devoção ao crucifixo e os milagres por ele realizados faziam-se presentes no imaginário cristão espanhol do século de ouro, e assim compreender melhor as polêmicas que envolveram o caso do Cristo da Paciência.

\section{Cristocentrismo: o culto à Cruz, ao sofrimento e ao sangue de Cristo}

O cristocentrismo, a devoção centrada na figura de Cristo e em sua Paixão, expandiu-se na Europa Ocidental entre os séculos XIV e XV, mas o seu ápice aconteceu no período pós-tridentino. Como indício deste crescimento e difusão podemos citar as

\footnotetext{
107 BLEDA, Jaime Juan. Los Cuatrocientos milagros, y muchas alabaças de la Santa Cruz. 1600. Valencia, p. 7.

${ }^{108}$ Nos capítulos subsequentes iremos voltar a esta obra.

${ }^{109}$ Milagre 16. BLEDA, Jaime Juan. Los Cuatrocientos milagros, y muchas alabaças de la Santa Cruz, 1600, pp. 135-142.

${ }^{110}$ BLEDA, Jaime Juan. Los Cuatrocientos milagros, y muchas alabaças de la Santa Cruz, 1600, pp. 301-304.

${ }^{111}$ BLEDA, Jaime Juan. Los Cuatrocientos milagros, y muchas alabaças de la Santa Cruz, 1600, pp. 312-313.
} 
diversas procissões da Semana Santa nas ruas de Toledo e Madri, bem como o aumento das confrarias e hermandades do Sangue de Cristo ${ }^{112}$.

A dupla natureza de Cristo, divina e humana, foi a base da religião cristã, apesar de em determinados momentos ter-se valorizado mais a sua natureza divina e em outros sua natureza humana. Mas foi a espiritualidade de São Bernardo de Claraval e a de São Francisco ${ }^{113}$ que "canalizaram as devoções populares da humanidade de Cristo em aspectos específicos de seu sofrimento, ou seja, foram os promotores diretos do culto às cinco chagas e ao [seu] sangue"114. Em outras palavras, neste período surgiu a percepção religiosa de um Jesus terreno ${ }^{115}$. Sem embargo, a progressiva devoção ao sofrimento carnal de Cristo não negava em nenhuma instância a sua divindade ${ }^{116}$, mas antes era o resultado da compreensão de que Deus encarnado através da humanidade de seu Filho, Jesus Cristo, sofreu para a salvação de seus fiéis. E na Espanha pós-Trento, esta sensibilidade religiosa com base na piedade e no sofrimento de Cristo se expandiu, adaptando-se às necessidades espirituais da época. Os grandes responsáveis pela continuidade do culto ao sofrimento de Cristo foram os místicos como Santa Teresa e Frei Luís de Granada ${ }^{117}$, que com seus textos

no solamente ejercieron importancia dentro de la Iglesia oficial, sino que calaron perfectamente dentro de la espiritualidad popular. La plasmación de sus contenidos en el arte, de pie a que se creen nuevas iconografías y aproximaciones hacia le representación de Cristo [...] las procesiones realizadas en Semana Santa

\footnotetext{
${ }^{112}$ LUNA MORENO, Luis. Sangre de Cristo y Cristo de la Sangre. Planteamientos iconográficos en España y Europa. In: MOYA MARTÍNEZ, Jose Juan. Vid Salvífica. actas de las VI Jornadas Nacionales de Contrarias Medievales de la Sangre de Cristo. Calasparra: Antigua y Venerable Cofradía de la Sangre de Cristo y la Vera Cruz de Calasparra, 2010, pp. 257-276.

${ }^{113}$ Foi no século XII, com a figura de São Francisco de Assis que nasceu a compreensão e a identificação com o sofrimento de Cristo, e para isto o bom cristão procurou imitar suas virtudes e participar de sseu sofrimento VELANDIA ONOFRE, Darío. Hacia una teología de la imagen. Mística, oratória y pintura en la España del Siglo de Oro, 2014, p. 73.

${ }^{114}$ VELANDIA ONOFRE, Darío. Hacia una teología de la imagen. Mística, oratória y pintura en la España del Siglo de Oro, 2014, p.74.

${ }^{115}$ Para historiadora Raquel Torres Jiménez, a percepção de um Cristo humano, trouxe também uma nova percepção de mundo, uma visão positiva das ações humanas, tanto no âmbito moral como politico. TORRES JIMENEZ, Raquel. Notas para una reflexión sobre el cristocentrismo y la devoción medieval de la Pasión y para su estudio en el medio rural castellano. Hispania Sacra, Madrid, 2006,118, p.452.

116 NAVARRO ESPINACH, Germán. Las cofradías de la Vera Cruz y de la Sangre de Cristo en el Corona de Aragón. Anuario de estudios Medievales. Barcelona, 2006, nº 36, p. 585.

${ }^{117}$ VELANDIA ONOFRE, Darío. Hacia una teología de la imagen. Mística, oratória y pintura en la España del Siglo de Oro, 2014, pp. 71-72.
} 
por las cofradías penitenciales son, tal vez, el ejemplo más claro de esta evolución del culto pasional ${ }^{118}$

O desenvolvimento da devoção ao sangue de Cristo esteve relacionado a relíquias como gotas de sangue e fragmentos da Cruz e da coroa de Espinho ${ }^{119}$, bem como o sangue de supostos milagres de hóstias e imagens (crucifixos) sangrantes ${ }^{120}$, juntamente com as práticas das confrarias de apresentar estas relíquias aos fiéis ${ }^{121}$. Tais apresentações durante o século XVII transformaram-se em grandes espetáculos e contaram com respaldo da Igreja, mediante a regularização das confrarias e de suas festividades, como também da piedade popular - piedade esta que era expressa através da flagelação dos penitentes que derramavam seu sangue, em um gesto simbólico de imitação $^{122}$.

Em paralelo às confrarias, a literatura mística também reforçava o valor do sangue de Cristo, como o texto de Frei Luis de Granada:

la carne bendita se abrió por todas partes y dio lugar a la sangre que manse por toda ella en tanta abundancia que corriese por toda tierra...Si no puedes llorar por falta de amor a lo menos llora por la muchedumbre de tus pecados, pues ellos fueron la causa de este dolor... ${ }^{123}$

Desta forma, os gestos e as atitudes de imitação do sofrimento e da compaixão passaram a fazer parte da conduta social ${ }^{124}$; o martírio e a lamentação pública diante de

\footnotetext{
${ }^{118}$ VELANDIA ONOFRE, Darío. Hacia una teología de la imagen. Mística, oratória y pintura en la España del Siglo de Oro, 2014, p 75.

${ }^{119}$ Ver: VAUCHEZ, André. Du culte des reliques à celui du Précieux Sang. Tabularia « Études ». Caen, $2008, n^{\circ} 8$.

${ }^{120}$ LUNA MORENO, Luis. Sangre de Cristo y Cristo de la Sangre. Planteamientos iconográficos en España y Europa, 2010, p. 260; Tomás de Aquino em uma pequena passagem de sua Suma Teologica trata destas relíquias de sangue: "Todo o sangue corrido do corpo de Cristo, pertencendo realmente ànatureza humana, ressurgiu com o seu corpo. E o mesmo devemos dizer de todas as partículas realmente pertencentes à natureza humana em sua integridade. Quanto ao sangue conservado por certas Igrejas como relíquias, esse não correu do lado de Cristo; mas é considerado como tendo jorrado milagrosamente de alguma imagem sua, objeto de qualquer violência”. Aquino, Tomás de. Suma Teológica. Terceira Parte, Questão 54. http://permanencia.org.br/drupal/node/3512. Acesso em 24/11/2015.

${ }^{121}$ Sobre o desenvolvimento das confrarias ver: NAVARRO ESPINACH, Germán. Las cofradías de la Vera Cruz y de la Sangre de Cristo en el Corona de Aragón, 2006, pp 583-661.

${ }^{122}$ Para o autor, as práticas destes rituais de derramamento de sague coletivo se deram junto às transformações religiosas, mas ao mesmo tempo houve uma série de consequências sociais e culturais, que estiveram relacionadas ao sistema de controle criado pelas esferas de poder. VELANDIA ONOFRE, Darío. Hacia una teología de la imagen. Mística, oratória y pintura en la España del Siglo de Oro, 2014, pp. 77-80.

${ }^{123}$ GRANADA, Fray Luis de. Libro de la Oración y la Meditación. In: Obras Completas XVIII. Madrid: FUE, 1994, cap 5.

${ }^{124} \mathrm{O}$ Concílio de Trento também tratou da necessidade de penitencia, como no trecho a seguir da sessão XIV, Doutrina do Santo Sacramento da Penitencia, de 25 de novembro de 1551: "Foi realmente
} 
uma imagem de Cristo eram não só bem vistos como também incentivados pelos eclesiásticos. Desta feita, tais comportamentos eram compreendidos como parte da identidade cristã espanhola.

Por outro lado, as confrarias e os grandes atos públicos fizeram dos fiéis agentes dos rituais, elementos conformadores das representações religiosas e estéticas da época $^{125}$. O signo da cruz $^{126}$ teve papel de máxima importância como ferramenta de evangelização $^{127}$, de arma contra os infiéis, como também de primeiro símbolo que seria violado por aqueles que se sentiam oprimidos pelo cristianismo.

E assim, estes atos iconoclastas contra crucifixos faziam a Espanha reviver constantemente o sofrimento de Cristo $^{128}$. E como uma resposta aos sacrilégios cometidos organizavam-se festas e procissões expiatórias. O melhor exemplo que podemos apresentar foram os inúmeros rituais de reparação, além do Auto de Fé de 1632 com a procissão introdutória da Cruz Verde,

una manifestación de carácter expiatorio: los fieles, tanto los que iban en la comitiva como los miles se encontraban entre el público presente, tenían la oportunidad de manifestar su aflicción por los delitos heréticos cometidos contra

\footnotetext{
necessária em todos os tempos para conseguir a graça e a salvação a todos os homens que incorressem na mancha de algum pecado mortal e também àqueles que pretendessem purificar-se com o sacramento do Batismo, de modo que abominando a maldade e emendando-se dela, detestassem tão grave ofensa a Deus, reunindo o aborrecimento do pecado com a piedosa dor de seu coração. Por isso diz o Profeta: "convertei-vos e fazei penitência de todos vossos pecados e com isso vossa iniquidade não será causa de vossa destruição". Também disse o Senhor: "Se todos vós, sem exceção, não fizerem penitência, todos vós perecereis". E o príncipe dos Apóstolos, São Pedro dizia, recomendando a penitência dos pecadores que deveriam receber o Batismo: "Fazei penitência e recebei todos o Batismo."

${ }^{125}$ Não estamos falando de uma participação mística ou milagrosa, mas as reações emocionais dos fiéis eram componentes do espetáculo visual.

${ }^{126}$ Importante ressaltar que a Crucificação de Cristo, antes de ser considerada um signo de glória, na Antiguidade representava a infâmia dos condenados de delitos graves. La cruz de Cristo: escándalo y locura. In: En Humanitas 18. http://humanitas.cl/html/biblioteca/articulos/d0014.html. Acesso em: $05 / 011 / 2015$.

127 Ver: RICO CALLADO, Francisco Luis. La imitatio Christi y los itinerarios de los religiosos: hagiografía y prácticas espirituales en la vocación religiosa en la España moderna. Hispania Sacra, Madrid, 2013, vol 65, No Extra 1, pp.127-152.

${ }^{128}$ Podemos citar alguns exemplos de Processos de Fé da Inquisição de Toledo depositados no Arquivo Historico Nacional de Madrid: Proceso de fe de Pedro Sánchez, vecino de Orgaz (Toledo), por sacrilegio al dar dos cuchilladas a la cruz de un camino, 1625, (INQUISICIÓN,226,Exp.11); Proceso de fe de Juan Barranquero, vecino de Pastrana, por sacrilegio al haber acuchillado una cruz, 1620-21 (INQUISICIÓN,225,Exp.1); Proceso de fe de Gaspar de Herrera, hijo de Anton de Herrera y vecino de Almodovar del Campo, por sacrilegio al haber dado con un palo a una cruz 1538 ( INQUISICIÓN,225,Exp.18); Proceso de fe de Fernando de Contreras, sastre y vecino de Almagro, por sacrilegio al haber pisado en una viña una bandera con un cruz de Calatrava, 1553 (INQUISICIÓN,225,Exp.4);
} 
la religión. Así, la procesión representaba en público la tristeza de la sociedad católica, o al menos la que se debía exigir a todo bueno creyente ${ }^{129}$.

Além disso, havia as fiestas de desagravio organizadas por confrarias ${ }^{130} \mathrm{e}$ conventos $^{131}$, das quais o monarca Felipe IV (1605-1665) e sua corte participavam, colaboravam para a manutenção da devoção ao Cristo da Paciência ${ }^{132}$.

\subsection{Política das imagens e a Inquisição}

Após as conversões forçadas ${ }^{133}$, as imagens sagradas passaram a ser um instrumento de validação da conversão, ou seja, possuir e cultuar imagens de Cristo, da Virgem e dos Santos foi considerado um indicador de que o converso haveria abraçado realmente a fé cristã.

$\mathrm{Na}$ documentação da Inquisição Espanhola encontramos múltiplos processos em que os cristãos-novos, tanto marranos (conversos do judaísmo) como mouriscos (conversos do islamismo), são acusados de praticarem delitos contra as imagens sagradas. Não estamos aqui tomando como fato verídico estas acusações, mas antes apontando uma ideia que circulava entre as autoridades católicas, a de que os cristãosnovos não teriam abraçado a fé católica sinceramente, o que seria denotado por supostos atos de ataques aos objetos visuais sagrados. Para entender este lugar comum do pensamento católico do período estudado, devemos nos ater à discussão sobre qual seria a relação dos muçulmanos e judeus com o culto às imagens religiosas.

\footnotetext{
${ }^{129}$ PULIDO SERRANO, Juan Ignacio. Injúrias a Cristo: religión, política y antijudaísmo en el siglo XVII, 2002, p 201.

${ }^{130}$ A festa no convento de Santo Domingo el Real, organizada pela Confradia de San Pedro Mártir.

131 Festa de desagravo da Iglesia de Las Reales Descalzas, da Capilla Real de Palacio, da Real Encarnacion, etc.

${ }^{132}$ PULIDO SERRANO, Juan Ignacio. Injúrias a Cristo: religión, política y antijudaísmo en el siglo XVII, 2002, pp. 225-268.

${ }^{133}$ Em 1492 para os judeus e 1502 para os mouros.
} 


\section{As imagens religiosas para os marranos}

É de senso comum na historiografia que o aniconismo da religião hebraica precede ao advento do Cristianismo, como o expresso na Torá: "Maldito seja o homem que faz uma imagem esculpida ou uma imagem em metal fundido, abominação para o Eterno, obra de artesão, e a põe em lugar secreto! E todo povo dirá: Amém”. $(\mathrm{Dt}, 27: 15){ }^{134}$

Segundo Felipe Espeso Pereda, somente entre os séculos XI e XII a questão das imagens passou a ser um problema entre cristãos e judeus, justamente quando no Ocidente as imagens passaram a ter maior influência na vida religiosa ${ }^{135}$ e os cristãos começaram a reprovar a atitude judaica perante a imagem. Paradoxalmente, desde Santo Agostinho, com base nos relatos do Antigo Testamento, fiéis da religião hebraica teriam propensão à idolatria. Mesmo vivendo na mesma cidade, não havia convivência social entre judeus e cristãos, o que teria contribuído para a permanência do topos judeu idólatra, mas que paulatinamente fora substituído pelo judeu iconoclasta, inimigo das imagens religiosas. Esta troca de qualidade negativa em relação aos objetos visuais religiosos começou por volta do século XII nos enfrentamentos intelectuais entre rabinos e teólogos cristãos, e nas seguidas acusações de que os judeus praticavam crimes rituais como a profanação de hóstias, simulação da paixão com crucifixos e até mesmo a crucificação de crianças cristãs ${ }^{136}$.

Mas para compreendermos o porquê deste senso comum, devemos compreender como era entendida a imagem religiosa para a fé hebraica. Para tal fim, recorremos a alguns parágrafos do Guia de Perplejo escrito em 1190 pelo filósofo Maimônides. No capítulo 35 (todos devem saber que Deus é incorpóreo e isento de paixões), ele sustenta que, como Deus é infinito e único e não ocupa lugar, não há figura

\footnotetext{
${ }^{134}$ Ver: BESANÇON, Alain. A imagem proibida: uma história intelectual da iconoclastia. Rio de Janeiro: Bertrand Brasil, 1997, pp. 106-128.

${ }^{135}$ ESPESO PEREDA, Felipe. Las imágenes de la discordia: política y poética de la imagen sagrada en la España del cuatrocientos, 2007, Posição 367-5673.

${ }^{136}$ Segundo Raul Gonzalez Salinero, tais acusações teriam acontecido em vários locais da Europa, e o primeiro caso que se tem noticia teria sido o assassinato ritual de um garoto na Inglaterra em 1144, relatado na legenda Vita et Miracula St. Wilelmi Norwicensi (1173) do monge beneditino Thomas de Monmuth. GONZÁLEZ SALINERO, Rául. Manos manchadas de sangre : los orígenes cristianos del mito antijidío del crimen ritual. In : Collectanea Christiana Orientalia v. 10. Cordoba: Universidade de Cordoba, 2013, pp. 65-82.
} 
ou imagem. Ou seja, seria impossível representá-lo materialmente, visto que ele não ocupa lugar. No capítulo 36, o autor define a idolatria, dizendo que não se trata somente de adorar imagens de madeira ou pedra, mas sim acreditar que uma forma material atue como um agente entre Deus e os homens ${ }^{137}$. O que percebemos é que a própria concepção de divindade judaica exclui a possibilidade da sua representação.

Uma fonte interessante, e que pode apontar a relação do cristão-novo com as imagens sagradas, seria o libelo que circulou por Sevilha no final do século XV, provavelmente escrito por um criptojudeu. Infelizmente não existe mais um exemplar deste panfleto, apenas temos conhecimento a seu respeito pelas contestações da obra Católica Impugnación del herético libelo, de Frei Hernando de Talavera ${ }^{138}$. O panfleto, do autor desconhecido, além de exprobrar as medidas de pressão sobre a comunidade criptojudaica, criticava as tradições católicas, considerando-as herdeiras do paganismo por adorar imagens. Em outro momento, diz que os cristãos recém-conversos do judaísmo estariam mais próximos ao Jesus histórico, pois respeitavam mais as leis do Antigo Testamento ${ }^{139}$.

Não obstante, temos conhecimento de cristãos-novos que abraçaram o cristianismo e no que diz respeito ao culto às imagens religiosas não só o respeitavam como também escreveram tratados refutando os preceitos hebraicos. Este é o caso da obra do rabino convertido ao cristianismo Paulo de Santa María (Selemoh-Há Levi) que dedica um capítulo do seu Scrutinium Scripturarum $(1432)^{140}$ às imagens, no qual defende o poder emotivo destas, justificando assim sua presença nas igrejas. ${ }^{141}$

Cabe lembrar ainda que, com a conversão em massa ${ }^{142}$, a pressão sobre os conversos com as constantes ameaças da Inquisição acabou gerando uma condição de incerteza sobre a pertinência de possuir ou não crucifixos e imagens de santos em seus

\footnotetext{
${ }^{137}$ MAIMONIDES, Mose. Guia de los Descarriados y Perplejos - Maiomonides. Org: VALERA, Fernando. México: Oríon, 1947, p. 51.

138 MARQUEZ, Francisco. Estudio preliminar. In: TALAVERA, Frey Hernando de, Católica Impugnación, Barcelona: Juan Flores, 1961, p. 29.

${ }^{139}$ ESPESO PEREDA, Felipe. Las imágenes de la discordia: política y poética de la imagen sagrada en la España del cuatrocientos, 2007, Posição 367-5673.

${ }_{140}$ A obra foi impressa entre 1488-1490 em Zaragoza. ESPESO PEREDA, Felipe. Las imágenes de la discordia: política y poética de la imagen sagrada en la España del cuatrocientos, 2007, Posição 9505673.

${ }^{141}$ ESPESO PEREDA, Felipe. Las imágenes de la discordia: política y poética de la imagen sagrada en la España del cuatrocientos, 2007, Posição 950-5673.

${ }^{142}$ Efetuada em 1492 na Espanha e em 1496 em Portugal.
} 
lares. As constantes acusações de profanação ritual ${ }^{143}$ levaram alguns conversos a temer possuir imagens e crucifixos, como defendeu o livreiro Luis Garcia ou Abraham García:

Oyendo las cosas y peligros que se syguían a los nuevamente convertidos de tener ymágines en sus casas y los testimonios que les levantavan diziendo que açotavan las ymágines y otros vituperios que cree que les levantan, ovo por bien de sufrir antes de no tener ymagen en su casa que no estar atado a un falso testimonio que una moça le quisiese levantar. ${ }^{144}$

Como podemos perceber, o culto às imagens religiosas foi um instrumento de coerção do tribunal do Santo Ofício, mas que ao mesmo tempo acabou dificultando a assimilação da fé cristã para a comunidade criptojudaica.

\section{As imagens religiosas para os mouriscos}

Da mesma forma como ocorreu com judeus na Península Ibérica, foi imposto aos muçulmanos o cristianismo ${ }^{145}$, com seus dogmas sobre Cristo Salvador ${ }^{146}$, a Trindade, o culto à Virgem ${ }^{147}$, aos santos e às imagens sagradas. A imposição do culto cristão e seus dogmas poderia ter suscitado repulsa à sua figura central, o que eventualmente poderia ter culminado em ataques ao crucifixo ${ }^{148}$. Não se tratava de os muçulmanos odiarem Cristo, mas de não o aceitar como filho de Deus (Alá) e partícipe

\footnotetext{
${ }^{143}$ Como o caso da família de Gonzalo Garcia de Santa Maria, acusados de profanar um crucifixono final do século XV na cidade de Zaragoza.

${ }^{144}$ Apud: ESPESO PEREDA, Felipe. Las imágenes de la discordia: política y poética de la imagen sagrada en la España del cuatrocientos., 2007, Posição 421-5673.

${ }^{145}$ Em 1496 em Portugal, onde a expulsão ou a conversão forçada valeu-se para as duas religiões. Já na Espanha as sanções de expulsão aos mouros tiveram início entre 1501 e 1525, mas foi efetivada somente em 1614. BARROS, Maria Filomena Lopes de. Os Muçulmanos de Portugal: a lusofonia como metáfora (séc. XII-XV). In: Tópicos Transatlânticos: Emergência da Lusofonia num Mundo Plural. Évora: U. Évora. 2012, p. 104.

${ }^{146}$ Cristo, para a religião muçulmana, é uma figura importante, pois teria anunciado a vinda de Maomé, sendo assim um modelo a ser seguido. Porém não é considerado filho de Deus, e os passos da Paixão e o dogma da Trindade não são observados. FRANCO LLOPIS, Francisco de Borja. Espiritualidade, Reformas y Arte en Valencia (1545-1609), 2007, p. 255.

${ }^{147}$ Maria para os muçulmanos, ao contrário do que poderíamos pensar, é considerada um modelo de mulher a ser seguido, o que eles condemam são as concepções cristãs de que Maria seria a "Mãe de Deus" e da sua virgindade após o parto. FRANCO LLOPIS, Francisco de Borja. Espiritualidade, Reformas y Arte en Valencia (1545-1609), 2007, pp. 256-260.

${ }^{148}$ Das atas da Inquisição de Valencia, podemos citar o exemplo do converso Matheo Carreras, que em 1604 teria dito que um crucifixo "le viniera en las manos lo despedaçara y desgarrar [...]que tomaria el Christo y lo despedaçaria y le pondria debaxo de sus pies no queriendo morir como christiano" AHN. Livro 938. Relación de causas de fe desde el año 1596 hate ela õ de 1608, fol. 215. Apud. FRANCO LLOPIS, Francisco de Borja. Espiritualidade, Reformas y Arte en Valencia (1545-1609), 2007, p 251.
} 
de sua divindade. Ademais, para os muçulmanos, Cristo $(E y c ̧ a)$ não teria sido martirizado e nem crucificado, mas teria sido um dos mais importantes profetas ao lado de Moisés e Maomé ${ }^{149}$, e sua figura deveria ser respeitada como um modelo de homem bom que teria servido a Alá ${ }^{150}$.

Já o culto as imagens sagradas no mundo islâmico, segundo Alain Besançon,

tornou-se inconcebível por causa da noção Metafisica de Deus. Basta o ato de submissão (islam) a esse Deus (shirk) para fazer com que a associação dele a qualquer conceito exterior à sua essência, a qualquer pessoa (como entre os cristãos) e, como mais forte razão, a qualquer matéria, seja vista com horror como uma agressão à unidade, como retorno ao politeísmo ${ }^{151}$.

O rechaço ao culto às representações materiais de divindades não é explícito no Alcorão, e sim nos hadiths ${ }^{152}$ e fatwas $^{153}$, que afirmam ser desonesto fazer representações artísticas de Deus, pois este manteve sua pureza e não reencarnou, sendo ilícito convertê-lo em uma imagem material ${ }^{154}$. Estamos falando mais uma vez de uma concepção de divindade irrepresentável.

A imposição do culto às imagens aos mouriscos trouxe dúvidas e mal estar no seio desta comunidade, e o Muftí de Orán, em 1563, recomendou que:

si a la hora de la oracíon se os obligase a ir a adorar los ídolos cristianos, formaréis intención de acer la tacbir de alihram ${ }^{155}$, y de cumprir vuestra oración; y vuestra mirada se dirigirá hacia los ídolos cuando los cristianos lo hagan; mas vuestra intención se encaminará s Dios, aunque no estéis situados de cara hacia la alquibla $^{156}$, a la manera que hacen oración los que en la guerra se hallan frente al enemigo. ${ }^{157}$

\footnotetext{
${ }^{149}$ FRANCO LLOPIS, Francisco de Borja. Espiritualidade, Reformas y Arte en Valencia (1545-1609), 2007, pp. 247-256

${ }^{150}$ FRANCO LLOPIS, Francisco de Borja. Espiritualidade, Reformas y Arte en Valencia (1545-1609), 2007, p. 255.

${ }^{151}$ BESANÇON, Alain. A imagem proibida: uma história intelectual da iconoclastia, 1997, p. 130.

${ }^{152}$ Conjunto de textos de leis e legendas sobre a vida de Maomé.

${ }^{153}$ Leis religiosas sobre tema específico.

154 FRANCO LLOPIS, Francisco de Borja Franco. Espiritualidade, Reformas y Arte en Valencia (1545-1609), 2007, pp. 261-262.

${ }^{155}$ Parte inicial da oração quando se repete: Alá é o maior.

${ }^{156}$ Direção à Meca

${ }^{157}$ Apud: GARCIA GARCIA, Maria del Rosário. Identidad y minorías musulmanas en Colombia. Bogotá: CEPE, 2007, p. 31.
} 
O lado reverso desta atitude impositiva de evangelização poderia ter sido as atitudes iconoclastas, que encontramos na documentação da Inquisição ${ }^{158}$ ou figurada na pintura de 1681, Cristo de Medinaceli arratrasdo por las calles de Mequinez, de Juan de Valdés Leal (Figura 7).

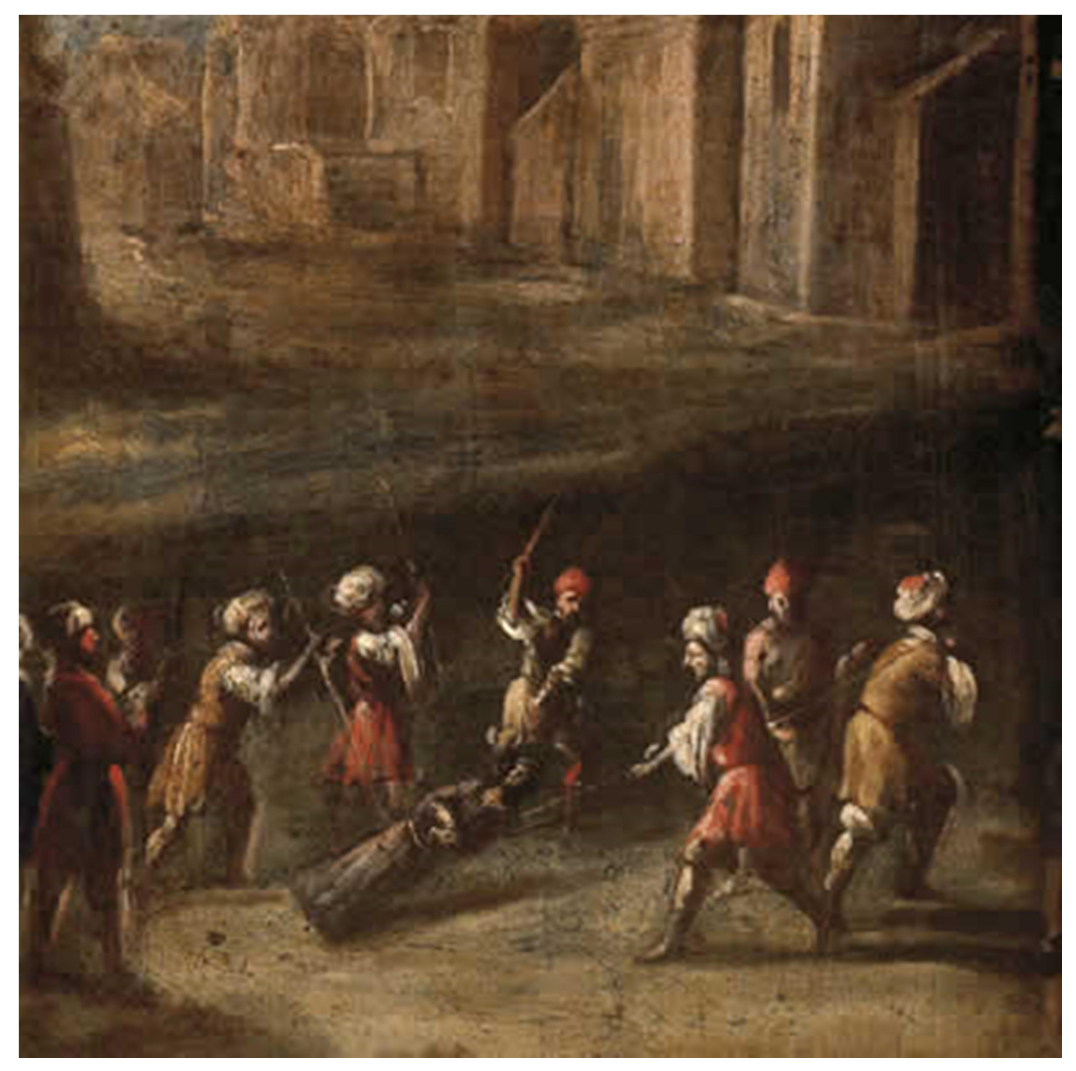

Figura 7 - Cristo de Medinaceli arrastrado por las calles de Mequinez, óleo sobre tela, $25 \mathrm{~cm}$ x $30 \mathrm{~cm}, 1681$; Juan de Valdés Leal, Fundação Casa Ducal de Medinaceli.

\section{A Inquisição e as imagens}

Até o início do século XII, os crimes contra a fé eram investigados apenas no âmbito das arquidioceses, sem regularidade ou regulamentação. Porém, o agravamento dos casos de heresias sinalizou ao poder pontifício a necessidade de intervenção. Em

158 Como o caso dos mouriscos Luis Rebollo e Joan Cigueba que teriam atacado uma cruz em 1574. Apud: FRANCO LLOPIS, Borja. Noticias sobre arte y devoción del Quinientos Aragonés a través de la documentación inquisitoria. Boletín del Museo e Instituto Camón Aznar, Zaragoza, 2011, nº 107, p. 71. 
1184, no Concílio de Verona, o papa Lúcio III, através da bula Ad Abolendam, determinou que os bispos deveriam visitar regularmente suas dioceses para investigar possíveis casos de heresias. Posteriormente, o papa Gregório IX (1221-41) compilou as normas estabelecidas na bula de Lúcio III nas suas Decretais, pelas quais outorgou aos padres Dominicanos o poder de instaurar o Tribunal da Inquisição. O Tribunal da Inquisição do período medieval era composto por dois inquisidores, ambos designados pelo papa, com jurisdição apostólica, que deveriam visitar as vilas e cidades e promulgar um "edito de fé", pelo qual todos eram obrigados a denunciar os hereges ${ }^{159}$ da região sob a pena de excomunhão. Após as delações, iniciavam-se os processos, com o uso de tortura autorizado desde 1252 pelo papa Inocêncio IV, através da bula $\mathrm{Ad}$ extirpanda ${ }^{160}$. Os inquisidores dos tribunais do Santo Ofício atuavam como delegados do papa, mas também contavam com o apoio das autoridades régias para aplicação das penas:

sendo uma instituição eclesiástica, a Inquisição só podia, em princípio, impor penas 'espirituais'; mas entregando [...] à justiça civil, os condenados, submetendo-os, implicitamente, à pena de morte e de confiscação dos bens, que o direito civil estatuía para certos crimes, entre os quais os de heresia ${ }^{161}$

Entretanto, não havia um estatuto que regulamentasse a relação entre o poder temporal e espiritual. No medievo, o controle da Inquisição era exercido pelo papado, visto que a sua atuação era exclusiva para os cristãos batizados que se afastavam da fé $^{162}$. A atuação do braço temporal dependia de cada localidade ${ }^{163}$.

De modo distinto, a Inquisição Espanhola e mais tarde a Portuguesa, ao serem instituídas nestas localidades, atuaram através de uma dinâmica de poder em que o controle das investigações não estava centralizado em Roma, como veremos a seguir.

Após a retomada de grande parte do território castelhano, os Reis Católicos se dedicaram a reorganizar a política, o que esbarrou em uma questão importante: os principais cargos no governo das cidades e da monarquia eram exercidos por cristãos-

\footnotetext{
159 As heresias investigadas eram as dos cátaros, valdenses e beguinos, as hetoroxias espiritais, etc. MARTINEZ MILLAM, José. La Inquisición española. Madrid: Alianza, 2007, p. 45.

${ }^{160}$ MARTINEZ MILLAM, José. La Inquisición española, 2007, p. 45.

${ }^{161}$ SARAIVA, António José. Inquisição e Cristãos-novos. Lisboa: Estampa, 1994, p. 20.

${ }^{162}$ A Igreja não deveria ocupar-se com os demais credos, tanto os judeus como os muçulmanos não poderiam ser investigados pelos tribunais inquisitoriais. Não obstante, sabemos que membros da igreja estiveram envolvidos em perseguições a não cristãos antes da modernidade.

${ }^{163}$ SARAIVA, António José. Inquisição e Cristãos-novos, 1994, p. 20.
} 
novos. Desde os finais dos séculos XIV, os cristãos que haviam lutado junto à monarquia na retomada do território começaram a manifestar sua insatisfação com relação aos judeus que estavam ocupando cargos importantes na administração monárquica. Com efeito, esta insatisfação converteu-se em perseguição, e no período de $1391^{164}$ a 1421 milhares de judeus converteram-se ao cristianismo. Porém, a conversão não significou integração, porque os conversos mantiveram seus costumes e ritos. Afinal a integração completa requereria uma assimilação não só religiosa, mas sociocultural, o que demandaria muito tempo e várias gerações. Essa dificuldade em assimilar o modo de vida cristão foi o maior argumento dos cristãos-velhos para continuar suas perseguições, acusando os criptojudeus de falsos conversos ${ }^{165}$.

Neste contexto, em setembro de 1480, os Reis Católicos, pressionados pelos cristãos-velhos e preocupados com os cristãos-novos que não estariam seguindo as tradições da religião cristã, nomearam os dominicanos Frei Miguel de Morillo e Juan de San Martin para investigar as causas heréticas em Sevilha ${ }^{166}$. Esta primeira convocação ocorreu dois anos após a promulgação da bula Exigit sinceras devotionis affectus (1478) pelo papa Sisto IV, que concedia aos Reis Católicos a instalação de um tribunal da Santa Inquisição com o poder para nomear três bispos para exerceram o ofício de inquisidores no reino. Em 1481, o Frei dominicano Tomás de Torquemada, confessor da rainha Isabel em sua juventude, passou a ocupar o cargo de Inquisidor Geral, e organizou os quatro tribunais permanentes do reino: Sevilha, Córdoba, Jaen e Toledo. ${ }^{167}$ Diferente da Inquisição medieval, na Espanha criou-se um novo tipo de organização religiosa, no qual a potestade apostólica delegou para os reis o controle da organização e do funcionamento dos Tribunais da Inquisição, e por este motivo podemos denominála Inquisição Espanhola. Ou seja, o Santo Ofício na Espanha se inseriu na estrutura

\footnotetext{
${ }^{164}$ Em Sevilha, as pregações de Ferrán Martinez contribuíram para os primeiros levantes e assaltos a judiarias, que se estenderam para outras localidades do reino. MARTINEZ MILLAM, José. La Inquisición española, 2007, p.53.

${ }^{165}$ MARTINEZ MILLAM, José. La Inquisición española, 2007, p. 53.

${ }^{166} \mathrm{Em} 6$ de fevereiro de 1481 ocorreu o Primeiro Auto de Fé em Sevilha. ALVAR EZQUERRA, Alfredo, La Inquisicio española. Madrid: Akal, 1997, p. 12; Ver também: RIBEIRO, Benair Alcaraz Fernandez. Arte e Inquisição na Península Ibérica, 2006, p. 42; MARTINEZ MILLÁN, José. La Inquisición Española, 2007, pp. 56-57.

${ }^{167}$ RIBEIRO, Benair Alcaraz Fernandez. Arte e Inquisição na Península Ibérica, 2006, p. 44; COMELLA, Beatriz. La Inquisición española. Madrid: Rialp, 1998, p, 43; MARTINEZ MILLÁN, José. La Inquisição Española. 2007, p. 57.
} 
monárquica, o que acabou funcionado como um instrumento de controle ideológico social dependente do monarca ${ }^{168}$.

Quando o tribunal da Santa Inquisição foi instalado na Espanha, o culto às imagens religiosas esteve na pauta dos debates entre as autoridades religiosas e dos reis. A pedido da rainha Isabel, o Frei jerônimo Hernando de Talavera e o cardeal da Espanha Pedro Gonzalez de Mendoza elaboraram as ordenações que estabeleceriam qual a prática correta a respeito das imagens religiosas ${ }^{169}$. Este pedido teria acontecido em 1478, quando a corte se fixara em Sevilha, e a rainha estava descontente com o comportamento dos cristãos-novos residentes naquela cidade ${ }^{170}$. No excerto a seguir o jerônimo apresenta a legislação que estabeleceria quais os usos que os recém-conversos deveriam dar às imagens sacras:

porque es cosa razonable que las casas de los fieles cristianos sean munidas y guardadas de la memoria de la pasión de nuestro Redentor Jesucristo y de su bendita Madre, queremos y ordenamos que cada fiel cristiano tenga en la casa de su morada alguna imagen pintada de la cruz, en que nuestro Señor Jesucristo padeció, y algunas imágenes pintadas de nuestra Señora o de algunos santos o santas, que provoquen y despierten a los que allí moran a haber devoción ${ }^{171}$

Portanto, possuir imagens religiosas no ambiente doméstico convertia-se em um signo exterior do bom cristão, cristão-velho ou converso. E o inverso, a ausência destas imagens seria um indicativo de que a conversão não fora sincera ${ }^{172}$. Este é caso do processo contra Marina Gonzalez, acusada de judaizante ${ }^{173}$ : “et por mostrar mejor su herejía no tenía en su casa imagen ni figura de santo, ni santa alguna, ni le señal de la cruz, ni otra señal de christiano, porque no se tenía por tal"174.

\footnotetext{
${ }^{168}$ CARRASCO VASQUEZ, Jesus Antonio. La minoria judeoconversa en la época del Conde Duque de Olivares, auge y ocaso de Juan Núñez Saraiva (1585-1639). Tese (doutorado em História) Departamento de História da Universidade de Alcalá. Alcalá de Henares, 2004. pp.302-303.

${ }^{169}$ Porém, não encontramos a documentação com tais sistematizações, apenas referencia a elas, como a Católica Impugnación del herético libelo, do frei jerônimo Hernando de Talavera.

${ }^{170}$ ESPESO PEREDA, Felipe. Las imágenes de la discordia: política y poética de la imagen sagrada en la España del cuatrocientos, 2007, Posição 203-5673.

${ }^{171}$ TALAVERA, Hernando de, Católica Impugnación del herético libelo, 1480.Capitulo 53, p 186.

${ }^{172}$ ESPESO PEREDA, Felipe. Las imágenes de la discordia: política y poética de la imagen sagrada en la España del cuatrocientos, 2007, Posição 385-5673.

${ }_{174}^{173}$ AHN Inq. Leg. 152 Exp. 14, Proceso de Marina Gonzalez.

${ }^{174} \mathrm{O}$ processo não está digitalizado, por este motivo só tivemos acesso a este trecho. Apud: ESPESO PEREDA, Felipe. Las imágenes de la discordia: política y poética de la imagen sagrada en la España del cuatrocientos, 2007, Posição 404-5673.
} 
Não obstante, possuir imagens religiosas em seus lares também foi capaz de tornar os cristãos-novos em alvos de outra categoria de denúncia, a de profanação ritual, como aconteceu com a acusação e a condenação das três famílias de conversos portugueses, do caso do Santo Cristo da Paciência:

- Proceso de fe de Beatriz Enriquez, doncella e hija de Miguel Rodriguez, natural de Viseo (Portugal) y vecina de Madrid, por judaizante y por haber azotado una imágen de Cristo crucificado - 1630 / 1633 - INQUISICIÓN,140,Exp.4ª

- Proceso de fe de Fernán Báez, portugués natural de la Torre de Mancorbo, vecino de Viseu (Portugal) y estante en Madrid, por judaizante y por haber azotado la imágen de un Cristo crucificado - 1630/1632 INQUISICIÓN,140,Exp.4b

- Proceso de fe de Victoria Méndez, mujer de Enrique Méndez, portuguesa natural de Viseo y residente en Madrid, por judaizante y por haber azotado una imágen de Cristo crucificado - 1630 / 1632 -INQUISICIÓN,140,Exp.4c

- Proceso de fe de Violante Méndez, hija de Domingo Luís y Beatriz Núñez, portuguesa natural de Viseo y residente en Madrid, por judaizante y por haber azotado una imágen de Cristo crucificado - 1630/1632 INQUISICIÓN,140,Exp.4d

- Proceso de fe de Isabel Núñez Álvarez, mujer de Miguel Rodriguez, portuguesa natural de Viseo y residente en Madrid, por judaizante y por haber azotado una imágen de Cristo crucificado - 1630 / 1632 - INQUISICIÓN,140,Exp.4e

- Proceso de fe de Elena Núñez, viuda de Juan Núñez, portuguesa natural de Viseo y residente en Madrid, por judaizante y por haber azotado una imágen de Cristo crucificado - 1630 / 1632 - INQUISICIÓN,140,Exp.4f

- Proceso de fe de Beatriz Rodriguez, hija de Fernán Báez, fugitica portuguesa y residente en Madrid, por judaizante y por haber azotado una imágen de Cristo crucificado - 1629/1632 - INQUISICIÓN,140,Exp.4g 
- Proceso de fe de Miguel Rodriguez, portugues residente en Madrid, por judaizante y por haber azotado una imágen de Cristo crucificado - 1630 / 1632 INQUISICIÓN,140,Exp.4h

Deste modo, o culto às imagens religiosas acabou tornando-se um componente fundamental da identidade do ser cristão, e uma dificuldade para os recém-conversos, que não possuíam em suas tradições religiosas tal espécie de culto. Para mouriscos e marranos, a devoção às imagens e aos objetos visuais religiosos tornou-se problemática devido à concepção de divindade de suas antigas religiões. Logo, para a Santa Inquisição, questões relacionadas ao não culto e ao desrespeito às imagens religiosas miravam os recém-conversos em suas investigações, como pode ser evidenciado pelos inúmeros processos de fé, como os que recolhemos do Arquivo Histórico Nacional, na sessão do Tribunal da Inquisição de Toledo: o processo de fé de Alonso Pardo Palencia, acusado de sacrilégio ao negar adorar a cruz em uma sexta-feira $\operatorname{santa}^{175}$ ou de Bartolomé García, acusado também de sacrilégio por apedrejar uma cruz ${ }^{176}$.

Nos mais de 4000 processos de fé da Inquisição de Toledo existem inúmeras acusações de desrespeito às imagens sagradas, o que denota, a despeito da desconfiança que temos destas fontes, que as questões relativas aos ataques contra as imagens religiosas eram de extrema importância para aquela sociedade.

Afora as acusações de profanação, as imagens sagradas também poderiam ser usadas durante o interrogatório. Como apontou o historiador da arte Borja Franco Llopis, o desprezo aos objetos visuais religiosos fora usado pelos inquisidores para determinar se os acusados eram hereges quando durante o interrogatório o inquisidor mostrava um crucifixo ao réu com a intenção de perceber sua repulsa ${ }^{177}$.

A Inquisição Espanhola também foi um grande incentivador do uso das imagens religiosas como ferramenta de propaganda das instituições religiosas e da

\footnotetext{
${ }^{175}$ AHN Inq. Leg. 226 Exp. 1, Proceso de Alonso Pardo Palencia.

${ }^{176}$ AHN Inq. Leg. 225 Exp. 12, Proceso de Bartolomé García.

177 FRANCO LLOPIS, Borja. Noticias sobre arte y devoción del Quinientos Aragonés a través de la documentación inquisitoria, 2011, p. 70.
} 
monarquia, como instrumentos de evangelização e conversão, e também como arma difamatória dos “inimigos” da fé católica: os judeus, muçulmanos e protestantes ${ }^{178}$.

Há também que se levar em conta que a visualidade foi explorada pela Inquisição de diversas formas. Este é o caso das procissões, dos autos de fé e das festas expiatórias. Os autos-de-fé possuem em sua gênese uma função de tribunal canônico, julgando crimes contra a religião católica, mas que no auge de sua dimensão religiosa era compreendida pelos expectadores e participantes com um juízo final ${ }^{179}$ :

Toda la disposición escenográfica, la abundante simbología y los estímulos sensoriales y emocionales, acercaban al observador atento a una realidad bien conocida por el común de la población, no por la experiencia sino a través de la naturalista descripción de muchos dos sermones oídos en sus parroquias: ese día apocalíptico en el que todas las almas desnudas ante al Gran Juez, diesen cuenta de sus acciones y pensamientos. Para algunos de los individuos entre el público era también "una apacible idea de la gloria"180

Ou seja, da mesma forma que uma representação pictórica do Juízo Final, o espetáculo religioso do Auto de Fé proporcionava aos fiéis (atores e espectadores) a sensação de salvação, pois estes se viam em meio àqueles que alcançaram a redenção, e os condenados, os hereges punidos pelas autoridades representantes de Cristo na Terra, quando relaxados, seriam as almas punidas pelo fogo do inferno.

\section{Os processos do Santo Oficio como fonte historiográfica}

Quando abordamos a documentação produzida pelo tribunal do Santo Ofício, as delações de malsins (os denunciantes), as declarações dos condenados, inquéritos de testemunhas e as sentenças, ou seja, os autos dos processos, devemos levar em conta a distorção dos fatos relatados ${ }^{181}$. Pois esses textos foram produzidos por pessoas que

\footnotetext{
178 Trataremos das representações dos hereges nos capítulos seguintes, quando analisarmos nossas pinturas.

${ }^{179}$ BETHENCOURT, Francisco. Historia das inquisições: Portugal, Espanha e Itália séculos XVXIX. São Paulo: Companhia das Letras, 2000. Introdução; RIBEIRO, Benair Alcaraz Fernandez. Arte e Inquisição na Península Ibérica, 2006, p. 161.

180 MORENO MARTINEZ, Doris. Ciros, trompetas y altares. El auto de fe como fiesta. Espacio, tiempo y forma. Barcelona, 1997, t. 10, p. 146.

${ }_{181}$ No capítulo seguinte apresentaremos o depoimento do pequeno Andresillo, que foi a testemunha principal do suposto milagre do Cristo da Paciência. O menino fora considerado pelos próprios
} 
acreditavam serem os portadores da verdade e, muito provavelmente, conduziam suas investigações no sentido de comprovar supostas certezas da existência de uma conspiração contra a fé católica. Por outro lado, delatores, testemunhas e réus respondiam às investidas inquisitórias mediante inúmeros sentimentos como a vingança, o medo, a dor, etc ${ }^{182}$.

Isto posto, como então podemos interpretar esta documentação para compreender a atitude iconoclasta? A prudência é a palavra chave. Só o Processo de Miguel Rodriguez ${ }^{183}$ contem 163 fólios, escritos à mão por diversos escrivães. Acreditamos que não poderemos encontrar nelas uma resposta concreta a respeito da atitude iconoclasta dos acusados, e de quais seriam os motivos para tais atos. Mas poderemos compreender, em certa medida, a importância que as imagens religiosas e o seu culto representavam para os cristãos católicos, bem como a instituição do Santo Ofício e a Igreja instrumentalizaram estes objetos visuais.

Além disto, sabemos que atitudes iconoclastas de fato aconteciam, as guerras de religião, além de mortos, deixaram muitas ruínas. As concepções religiosas judaicas e mouras também poderiam ser propulsoras de atitudes iconoclastas. Sem esquecer os cristãos-velhos que por inúmeros motivos podiam expressar seu ódio atacando imagens. Logo, podemos concluir que, por vezes, os relatos dados aos inquisidores poderiam ter realmente acontecido, mas temos que entender que os inquisidores filtravam todos os relatos; foram eles que decidiam o que perguntar, e, em muitos casos qual seria a resposta correta ${ }^{184}$. Assim aconteceu com Simón Luis, quando sob a tormenta da mancuerda ${ }^{185}$, disse que se o afrouxassem "que díria cuanto quisiesen..."186 - o que fez,

inquisidores como leso e seus quatro depoimentos foram incongruentes, e somente no último ele teria falado do milagre.

${ }^{182}$ GINZBURG, Carlo. Mitos, Emblemas e Sinais: Morfologia e História. São Paulo: Companhia das Letras, 1989, pp 15-39.

${ }_{183}$ AHN Inq. Leg. 140.Caixa 2. Proceso contra Miguel Rodriguez.

${ }^{184}$ PULIDO SERRANO, Juan Ignacio. Injúrias a Cristo: religión, política y antijudaísmo en el siglo XVII, 2002, pp 147-152.

${ }^{185}$ Método de tortura em que uma fina corda ligada ao redor de um dos braços da vítima que era puxada pelo seu peso ou era utilizado uma alavanca, que cortava sua pele. http://lexicoon.org/es/mancuerda. Acesso: 19/11/2015.

${ }^{186}$ Seu processo está arquivado junto aos de Violante Méndez. AHN Inq. Leg. 140. Proceso contra Violante Méndez. Apud. PULIDO SERRANO, Juan Ignacio. Injúrias a Cristo: religión, política y antijudaísmo en el siglo XVII, 2002, p 151. 
confessando que o Cristo teria falado milagrosamente em duas ocasiões, em Gradix (Portugal) e Madri ${ }^{187}$.

\subsection{Iconoclastia Ibérica}

Nomeamos o fenômeno (a violência contra as imagens) em estudo nesta pesquisa com um termo mais tradicionalmente utilizado para designar atos de agressão a imagens sagradas desde o século VII, em Bizâncio: iconoclastia. Cumpre ressaltar que na documentação escrita contemporânea ${ }^{188}$ às pinturas analisadas, tais atos receberam outras denominações. No Ocidente cristão, frequentemente os ataques às imagens religiosas foram assinalados como sacrilégio, irreverência, quebra de imagem, profanação, injuria, blasfêmia e desacato. Ao analisar os processos da Inquisição espanhola, além destas designações encontramos também acusações de práticas "judaizantes"189, "luteranismos"190, ou "de mouros"191. Tais termos, qualificadores de uma determinada fé, quando aparecem nestas fontes como um delito, além de atos iconoclastas, poderiam significar uma infinidade de "heresias" ou "pecados", que não cabem ser discutidos aqui ${ }^{192}$. Iremos chamar a todos de iconoclastia, a fim de não desviarmos o foco de atenção de nosso trabalho, que são as imagens. Mas é importante lembrar essas variações, a fim de perceber a carga negativa que elas recebiam, a ponto de serem designadas como heresias ou pecados.

\footnotetext{
${ }^{187}$ PULIDO SERRANO, Juan Ignacio. Injúrias a Cristo: religión, política y antijudaísmo en el siglo XVII, 2002, p. 151.

${ }^{188}$ Denúncias das atas da Inquisição Portuguesa e Espanhola, poesias e sermões.

189 Eram condenados por delitos judaizantes além daqueles em condição judaica "otras actuaciones punibles según el derecho inquisitorio (blasfemias contra símbolos cristianos, proselitismo judaico, ataques a la Inquisición, tenecia y difusión de libros prohibidos, desprecio a las imágenes”, etc. SIERRA, Julio. Procesos de la Inquisicion en Toledo (1575-1610): Manuscrito de Halle. Madrid: Trotta, 2005, pp. 61-62.

${ }^{190}$ Eram consideradas heresias luteranas, como as de que mestre Bernardo (ANTT, Inquisição de Évora, processo $\mathrm{n}^{\circ}$ 8884) fora acusado, pois declaravam que as imagens religiosas são ídolos. COELHO, Antonio Borges. Inquisição de Évora: dos primórdios a 1668. Lisboa: Caminho-Colecção Universitária, 1987, p. 235.

${ }^{191}$ Nas causas vistas no Auto de Fé de 1603, consta a do soldado Francisco Ramirez de Valdo, foi acusado de mouro e teria dito "que los christianos creyan en unos palos y [...]que el y unos morros avian despedaçado um cruçifijo..." SIERRA, Julio. Procesos de la Inquisición en Toledo (1575-1610): Manuscrito de Halle, 2005, pp. 505-506.

${ }_{192}$ Sobre estas apostasias: SIERRA, Julio. Procesos de la Inquisición en Toledo (1575-1610): Manuscrito de Halle, 2005, pp. 61-110.
} 
O termo iconoclastia deriva do grego (eikon, ícone ou imagem e klastein, quebrar) e semanticamente significa o ato de quebrar imagens. O historiador holandês Jan N. Bremmer, em um artigo sobre a genealogia do termo iconoclastia ${ }^{193}$, afirma que mesmo no século VII, durante a chamada Querela das Imagens, a palavra eikonôklastes quase não era empregada. O historiador mostra que foi somente na segunda metade do século XX que se iniciou, de fato, o emprego deste termo nos estudos sobre ataque a imagens, embora o termo, em latim, tenha sido usado pela primeira vez, no Ocidente, no tratado do carmelita Thomas Netter ou Waldensis (1372-1431) Doctrinale antiquitatum fidei ecclesiae catholicae, de 1420: "execratores imaginum sub nomine iconoclastarum, latine fractorum imaginum" 194.

Quando refletimos sobre iconoclastia, para além do ato físico de destruição de imagem, devemos considerá-la como um fenômeno cultural histórico e global, ou seja, qualquer ato de destruição de imagens que ocorreu ao longo da história da humanidade em diferentes localidades e pelos mais diversos motivos. Em princípio, qualquer tipo de imagem, e não só a religiosa, mas também a artística e a política, pode despertar tais reações negativas $^{195}$.

$\mathrm{Na}$ tradição religiosa, o fenômeno da iconoclastia também ocorreu nos mais distintos momentos da história, em diferentes localizações e confissões. O mote quase ${ }^{196}$ basilar está na ação violenta para a proteção daquilo que é considerado como "Verdade Única" de cada religião, que mantém sua identidade em oposição à alteridade ${ }^{197}$. Ou seja, o ato iconoclasta não pretende apenas fazer desaparecer a imagem ou simplesmente destruí-la, a intenção ao agredir um objeto considerado sagrado de outra

\footnotetext{
193 BREMMER, Jan N. Iconoclast, Iconoclastic, and Iconoclasm: Notes Towards a Genealogy. In: Church History and Religious Culture 88. Leiden: Brill, 2008, 1-17

${ }^{194}$ WALDENSIS, Thommas. Doctrinale antiquitatum fidei Catholicae Ecclesiae adversus Wiclefitas et Hussitas ad vetera exemplaria recognitum \& notis illustratum. Livro III, cap. 179.

195 "Existiu sempre da parte dos homens - e continua a existir - uma deriva iconoclástica que se manifesta, em relação à imagem que adora, por que nutre encanto, respeito, desconforto, ou medo - de diferentes modos". SERRÃO, Vitor. A pintura maneirista e proto-barroca. In: RODRIGUES, Dalila (org.). Arte Portuguesa da pré-história ao século XX. Lisboa: Fubu, 2009, v.11. Ver também DIDIHUBERMAN, Georges. Poderes da figura. Exegese e visualidade na Arte Cristã. Revista de Comunicação e Linguagens, 1994, 20, pp. 159- 177.

${ }^{196}$ Este "quase" está aqui para não limitar esta proteção nas grandes disputas religiosas, pois se olharmos para a micro história encontraremos as mais diversas razões para se destruir uma imagem. Ver: FREEDBERG, David. El poder de las Imágines, 1992, pp. 423-474.

197 TEIXEIRA, Alfredo. Uma politica da imagem: leitura antropológica da blasfémia visual de Pierre Legendre. Revista Portuguesa de História, Coimbra, 2008, pp. 143-174.
} 
religião é questionar e até mesmo extinguir as práticas a ele relacionadas ${ }^{198}$. E nas religiões nas quais as imagens religiosas exercem funções místicas ou sobrenaturais ${ }^{199}$, o ataque não fere somente a devoção, mas também agride aquele a quem a devoção é dirigida, pois há uma relação direta entre a imagem e o modelo que é intrínseco àquela religião. Este é um problema teórico e religioso sobre a relação entre o original/protótipo e sua representação, na qual se opõem iconoclastas e iconófilos com suas divergentes posições sobre a relação entre espaço físico e o sagrado, entre os homens e Deus, e acreditamos que seu estudo não deva ocorrer sob uma premissa generalizadora, mas sim a partir das especificidades dos casos examinados.

No mundo cristão observamos vários momentos em que o fenômeno da iconoclastia ocorreu em grande escala, como no século VIII em Bizâncio ${ }^{200}$, e no século XVI na Europa ocidental ${ }^{201}$. Para o cristianismo, o culto às imagens e objetos visuais esteve, por séculos, imerso em um longo debate sobre sua pertinência nos rituais religiosos. No tocante à Península Ibérica a questão das imagens como já dissemos, em muitos casos, esteve relacionada aos cristãos-novos. Enquanto estes eram acusados pela Igreja de manterem-se anicônicos, a prática do culto às imagens tornou-se um símbolo irrepreensível da qualidade de cristão-velho ${ }^{202}$. Na Espanha, os casos de iconoclastia e injúrias a imagens proliferavam-se, e os acusados de tal agravo eram castigados com severidade pelo Santo Ofício. Para Felipe Espeso, a leitura da documentação da Inquisição mostra que a questão da devoção às imagens converteu-se em verdadeiro símbolo da discórdia social ${ }^{203}$. E para Dário Velandia Onofre, mais do que ultrajar as imagens, a intenção seria tornar públicos os ataques iconoclastas na Península Ibérica, para que os católicos se sentissem ofendidos com tais agravos ${ }^{204}$. Não obstante, o caso

198 EATOUGH, Matt. Theories of Media: Keywords Glossary: iconoclasm. University of Chicago: http://csmt.uchicago.edu/glossary2004/iconoclasm.htm. Ver também BELTING, Hans. Puissance et impuissance de l'image. Revue des sciences sociales, 2005, pp. 68-69.

199 Podemos citar algumas religiões em que as imagens sagradas funcionam não somente como representações de divindades, como o hinduísmo. Mas as imagens exercem funções místicas também no budismo, em religiões africanas, nos cultos maiori, etc. FREEDBERG, David. El poder de las Imágines: estudios sobre la historia y la teoria de la respuesta, 1992, pp. 107-126.

${ }^{200}$ Ver: BESANÇON, Alain. A imagem proibida: uma história intelectual da iconoclastia. 1997, pp. $179-238$.

201 FREEDBERG, David. El poder de las Imágines: estudios sobre la historia y la teoria de la respuesta, 1992, pp. 423-574.

${ }^{202}$ ESPESO PEREDA, Felipe. El debate sobre la imagen en la España del siglo XV: judíos, cristianos y conversos. Anuario del departamento de Historia y teoría del Arte, 2002, p. 62.

${ }^{203}$ ESPESO PEREDA, Felipe Las imágenes de la discordia: política y poética de la imagen sagrada en la España del cuatrocientos, 2007, Posição 63-5673.

${ }^{204}$ VELANDIA ONOFRE, Darío. Hacia una teología de la imagen. Mística, oratória y pintura en la España del Siglo de Oro, 2014, p. 278. 
relatado nas fontes da Inquisição, e que aqui estudamos, assume outra dinâmica, a de um ritual secreto, que no imaginário cristão seria comum no seio da comunidade criptojudaica $^{205}$.

Como pudemos observar, na Espanha do século XVII, o culto às imagens religiosas era parte fundamental daquele modo de vida católico. Independentemente da maneira como a essência daqueles objetos visuais era compreendida, o culto às imagens possuía um lugar privilegiado na vida religiosa e nas relações sociais, seja por meio do seu culto ou do seu questionamento.

\footnotetext{
${ }^{205}$ Sobre o suposto ritual de reincenar a paixão de Cristo, discutiremos mais adiante, mas este tema é tratado nas seguintes obras: RODRIGUEZ BARRAL, Paulino. La imagen del judío en la España medieval: el conflicto entre cristianismo y judaísmo en las artes visuales góticas. Barcelona: Memoriua Artium, 2008; CANTARE MONTENEGRO, Henriquez. El miedo al judío en la España de la Edad Media. Estudio de Historia de España. Buenos Aires: 2013, nº 13, pp 162-171.
} 


\section{Um projeto visual expiatório: o Convento e a Capela do Santíssimo Cristo da Paciência de Madri}

Neste capítulo iremos tratar da construção do Convento e da Capela do Santíssimo Cristo da Paciência de Madri e da encomenda das pinturas.

\subsection{A igreja do Real Convento da Paciência de Cristo ${ }^{206}$}

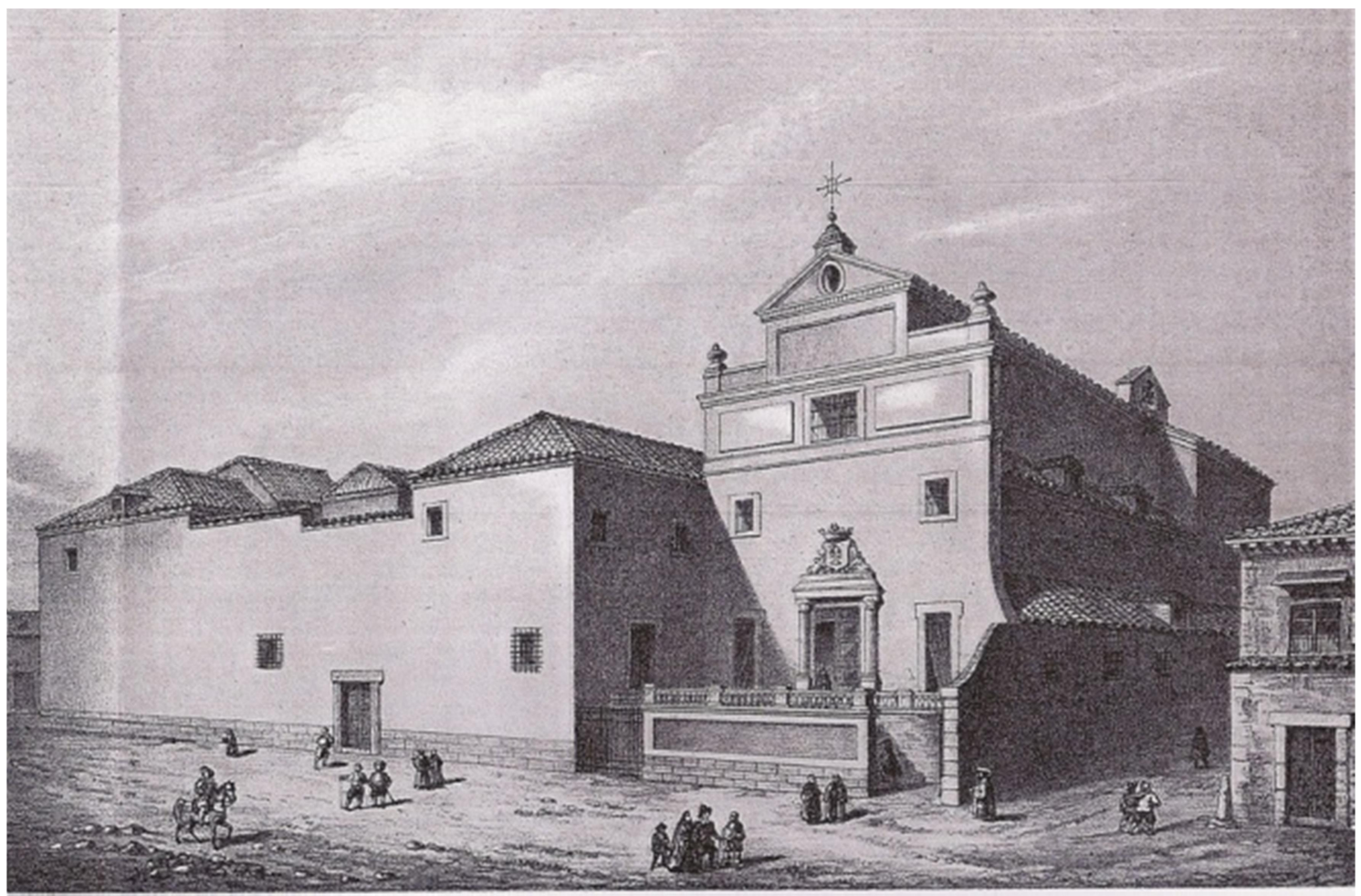

Figura 8 - Iglesia y Convento Capuchinos de la Paciencia, 15,5 cm x 22,3 cm, litografia, c. 1863, Biblioteca Nacional da Espanha [45981].

Infelizmente temos poucos indícios de como fora a capela e como as imagens estavam dispostas, embora em nossa pesquisa de campo tenhamos visitado alguns arquivos com o intuito de encontrar uma planta ou um desenho que nos pudesse dar uma ideia de como seria a Real Capilla del Santo Christo de la Paciencia. O que

\footnotetext{
${ }^{206}$ Outra denominação dada ao convento.
} 
encontramos foi uma planta (Figura 9) da casa onde viviam os cristãos-novos condenados. Segundo o frade capuchinho Matheo de Anguiano em sua obra La Nueva Jerusalen en que la perfídia hebraica reitero con novos ultrajes, de 1706, a capela ocupou todo o local da casa. Além disto, também encontramos o plano de Teixeira, finalizado em 1659, no qual vemos a primeira representação do convento e da capela (Figura 10), além de uma gravura do século XIX representando a fachada (Figura 8). 


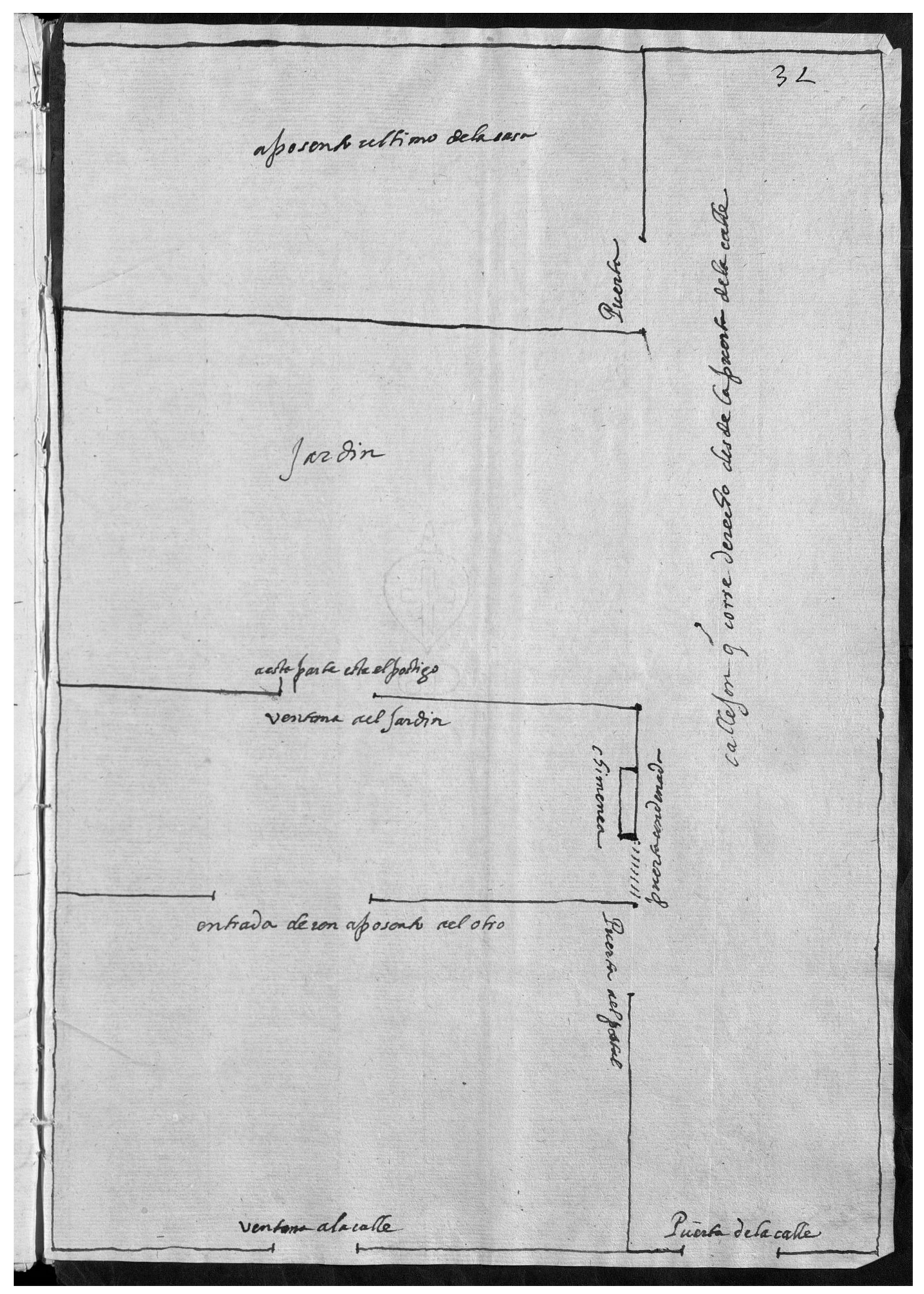

Figura 9 - AHN Inq. Leg. 140.Caixa 2. Proceso contra Miguel Rodriguez, fol 32r. 


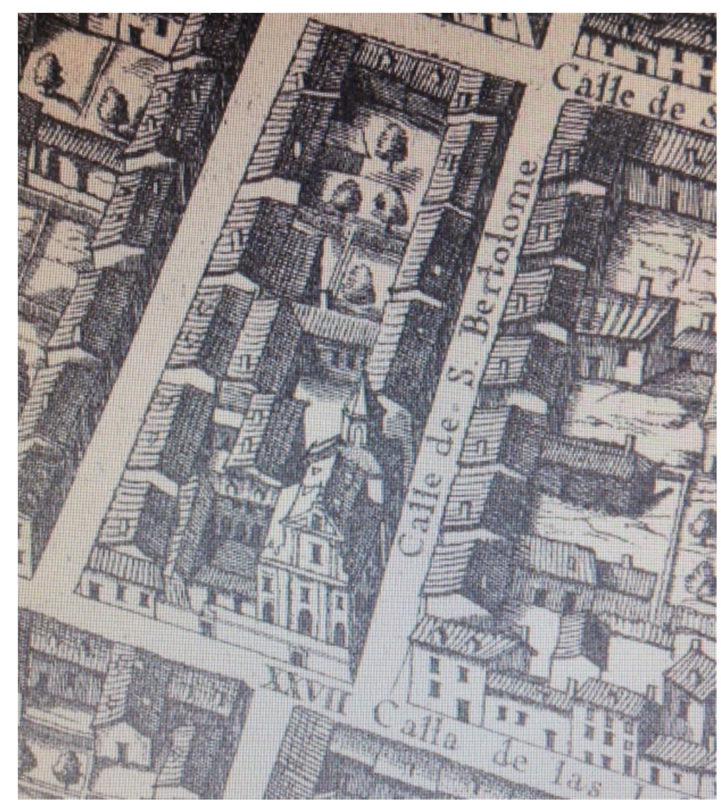

Figura 10 - Vista da Igreja e Convento dos Capuchinhos da Paciência de Madri, Detalhe: Madrid Ciudad Regia, gravura, 1659, Pedro Teixeira Albernaz, fl. 9 r.

No livro La Nueva Jerusalen en que la perfidia hebraica reitero con novos ultrajes, Anguiano descreve como era a igreja, sua simplicidade, seu formato retangular, os quadros que adornavam as paredes e o retábulo central, além de reproduzir o texto da inscrição em pedra identificando a origem e os patronos da Igreja, como podemos observar no excerto a seguir:

La Iglesia es asseada, y suficientemente capaz; pero no precioso el edificio. Tiene diferentes Tribunas para poder orar, y estar recogidas en ellas las personas de classe superior, que gustan de retiro, y huir del bullicio, y ostentacion. Y para eso apetecen ordinariamente la que està à los pies de la Capilla del Santo Christo, y mira derechamente à su Altar; la qual es bastantemente frequentada, no solo en los Viernes del año, sino tambien en otros dia de la semana, donde oyen las Missas que se dizen en la Capilla (que son muchas) y hazen sus Novenas, y devociones al Santísimo Christo.

La capilla es mas larga, que ancha, y contiene en su longitud, y latitud, todo aquel sitio en que injuriaron la Sagrada Imagen con tantos malos tratamientos, blasfemias, y ultrages, como ya dexamos referidos [...] De eso esta adornado este Venerabilissimo Santuario, y asi, nadie busque en el otras preciosidades de la tierra, que no las ay, sino las del Cielo, vinculadas en lo mucho que Jesu Christo Salvador Nuestro obrò aqui por su Imagen Sagrada del Crucifixo [...]. 
Todo esto, para memoria del sucesso, y para estos santo fin, se contiene historiado en los Quadros, que se veen en la misma Santa Capilla. Y aunque que los lienços son quatro, fue forçoso repartilos assi, para guardar la symetria de los espacios de las paredes; mas es cierto, que son cinco los pasos, y que en uno de dichos lienços se contiene $\operatorname{dos}^{207}$, con su linea de division, que los distingue. En una parte de esse lienço, se representa el afán, y ansia con que los crueles Judios pretendian abrasar la Imagen Sagrada, y como el fuego reverente la apartaba de si, y levantaba en alto. En otra parte se miran como estan destrozando la Sagrada Imagen con una hacheta, y arrojando en el fuego de los pedazos que iban quitando. No tienen rotulo dichos Quadros, como parece los pedian al pie de cada uno; pero essos estan grabados con letras grandes, y doradas en piedra de jaspe negro, en el escudo, o targeta grande, que ay en la misma Capilla, en la pared, a la mano izquierda, como entramos en ella, en que assimismo se conten la Inscripcion siguiente:

Reynado D. Phelipe Quarto el Grande, nuestro señor, con la Reyna nuestra señora D. Isabel de Borbon, se castigaron por el Santo Ofício de la Inquisicion unos hombres y mujeres, Hereges judaizantes, que vivian en las casas, que en este sitio se derribaron, por maltratar un Santo Crucifixo milagroso, en la forma que se mira en los Quadros desta Capilla. Y por honra, culto, y desagravio de Christo Nuestro Señor, mandaron sus Magestades se edificasse a su costa esta Iglesia, y Convento, para que los Padres Capuchinos alaben a Christo Nuestro Bien, con Advocacion de su Paciencia, donde fue ultrajado su Imagen. Siendo voluntad del Rey nuestro Señor, que esta Obra, y Patronazgo fuesse des afecto, y devocion de la Reyna nuestra señora Doña Isabel de Borbon, que la tomo por su cuenta, y en su muerte, la dexo encomendada al señor Don Antonio de Contreras, Cavallero del Orden de Calatrava, del Consejo, y Camara de su Magestad, que hizo hazer este Convento, Quadros de Pintura, y Letrero, para memoria de todo. ${ }^{208}$

Ao descrever os quadros que foram encomendados para ornar o templo expiatório, Aguiano apresenta cinco pinturas, das quais quatro estudamos aqui, e sobre a quinta ele diz representar:

Exemplar castigo, que el Santo Oficio de la Inquisicion mando executar en los perfidios Hebreos, que hizieran con el Santo Crucifixo los malos tratamientos que se refieren: siendo quemados publicamente à quatro de Julio de 1632 años ${ }^{209}$.

Porém, na sequência o frade expõe que não houve espaço na capela para esta quinta pintura. Pulido Serrano também comenta esta quinta pintura ${ }^{210}$, e apresentou

\footnotetext{
${ }^{207}$ A pintura de Andrés de Vargas, Martirio del Brasero.

${ }^{208}$ ANGUIANO, Mateo de. La nueva Jerusalen en que la perfidia hebraica reitero con nuevos ultrages la passion de Christo en su ss. imagen. del Crucifixo de la Paciencia en Madrid. Madrid: Impr. de Manuel Ruiz de Murga, 1709, pp. 298-301.

${ }^{209}$ ANGUIANO, Mateo de. La nueva Jerusalen en que la perfidia hebraica reitero con nuevos ultrages la passion de Christo en su ss. imagen. del Crucifixo de la Paciencia en Madrid, 1709, pp. 302-303.
} 
outra fonte em que ela também foi descrita, o Sermón a los desagravios de la soberana imagen del Santo Cristo de La Paciencia escrito e proferido por Don Martín Caballero de Isla em 1659 na Capela do Convento dos Capuchinhos da Paciência de Madriadri:

Veo enojado a Dios, cerrar las puertas de su misericórdia; fiar de un ministro grande, de venerable sacerdote, indutus lineis, el castigo: y veo que el Santo Tribunal del Santo Ofício los condena a muerte, les afrentoso garrote; y porque padezcan como vivieron, los arroja a las llamas, temporales a su pena, y eternas al escarmiento $^{211}$

Esta poderia ser então uma pintura semelhante à grande obra de $1683^{212}$, o Auto de Fé em la Plaza Mayor de Madrid (Figura 11), de Francisco Rizi, que figura o Auto de Fé de 1680, hoje exposta no Museu do Prado. Com efeito, as notas trazidas por estas fontes podem ser a evidência da existência desta quinta pintura, e que hoje estaria perdida em algum depósito, ornando alguma das inumeráveis igrejas existentes na Espanha, ou mesmo pode ter sido destruída como aconteceu com a pintura de Andrés Vargas.

210 PULIDO SERRANO, Juan Ignacio. Injúrias a Cristo: religión, política y antijudaísmo en el siglo XVII, 2002, p. 329.

${ }^{211}$ Apud: PULIDO SERRANO, Juan Ignacio. Injúrias a Cristo: religión, política y antijudaísmo en el siglo XVII, 2002, p. 329.

${ }_{212}$ https://www.museodelprado.es/coleccion/obra-de-arte/auto-de-fe-en-la-plaza-mayor-demadrid/8d92af03-3183-473a-9997-d9cbf2557462. Acesso em 18/12/2015. 


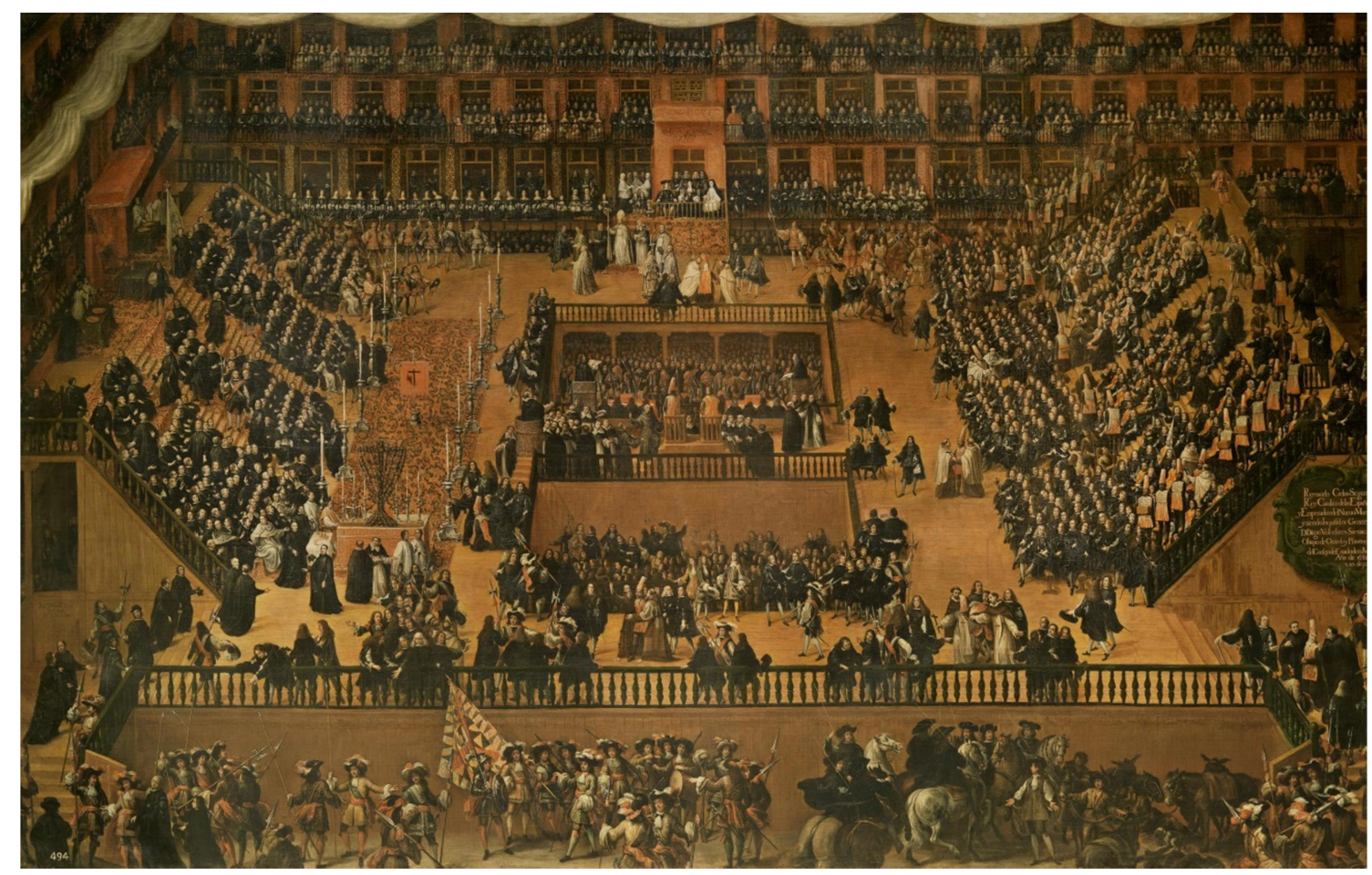

Figura 11 - Auto de Fe en la Plaza Mayor de Madrid, 1683, óleo sobre tela, $277 \mathrm{~cm} \mathrm{x}$ 438 cm, Francisco Rizo, Museo do Prado [P01126].

Sobre o retábulo central, Aguiano apenas cita que não é de talha, e sim em perspectiva, ou seja, uma pintura, mas não menciona qual. Segundo Palomino em $E l$ museo pictórico y escala óptica, a pintura que estaria "en el altar mayor" da igreja do Convento dos Capuchinhos da Paciência de Madri era a conhecida como Espólio de Cristo (Figura 12), de Francisco Rizi ${ }^{213}$. Esta mesma informação aparece no livro Viage de España de Antonio Ponz, escrito em 1782, que também faz uma pequena descrição da igreja e das pinturas: "No hay que tampoco para que detenermos en de esta Iglesia. La pintura del despojo de Christo en el Calvario [Expolio de Cristo], que ocupa quasi todo el altar mayor, la hizo D. Francisco Rizi..."214. Hoje, esta pintura pertence ao Museu do Prado e está exposta em uma capela lateral da Catedral de Almudena.

\footnotetext{
${ }^{213}$ PALOMINO, Antonio. El museo pictórico y escala óptica: Tomo segundo. Practica de la pintura. Madrid: Imprenta de Sancha, 1714, p. 409.

${ }^{214}$ PONZ, Antonio. Viage de España. Madrid: Ibarra, 1784, p. 230.
} 


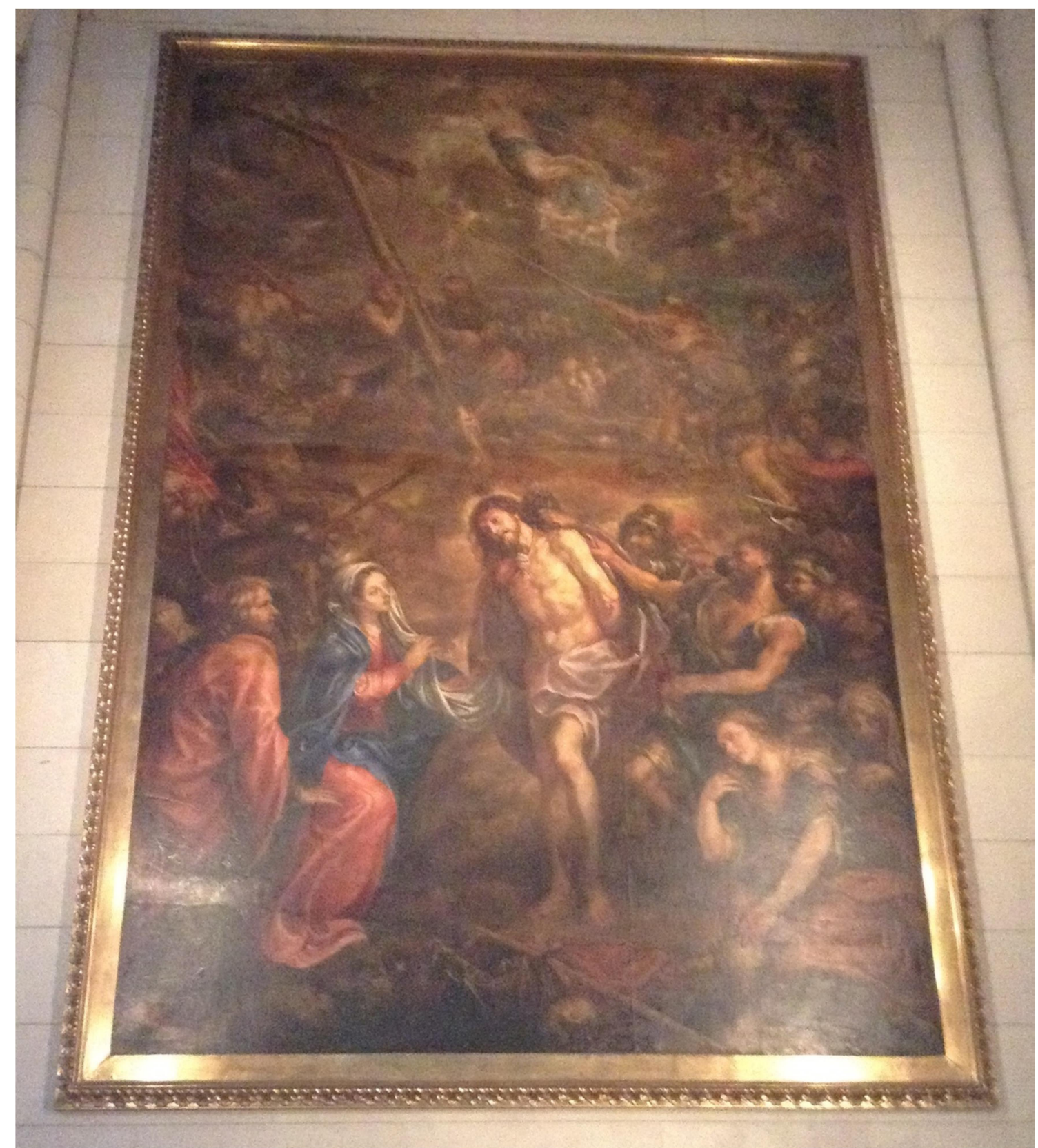

Figura 12 - Expolio de Cristo, 1651, óleo sobre tela, $527 \mathrm{~cm}$ x $352 \mathrm{~cm}$, Francisco Rizi, Museu do Prado, depositado na Catedral de Almudena [P02925]

A idealização e a construção do templo expiatório tiveram início com as sentenças do Santo Ofício, que além dos castigos aos acusados, ordenou que a casa onde eles teriam açoitado a milagrosa imagem de Cristo, fosse derrubada.

Manda el Santo Ofício de la inquisición de la Ciudad y Reyno de Toledo, derribar y assolar estas casas, donde vivieron Miguel Rodriguez y Isabel Nuñez Alvarez su mujer, judaizantes, hereticos, condenados porque en ellas se ayuntaban otros 
judios à judaizar y hazer concuenticulos contra nuestra Santa Fé Catolica y Iglesia Romana, y açotabã y maltrataban en ella un Santo Christo. ${ }^{215}$

Para iniciar o processo de sacralização, de quase vinte anos até 1651, quando enfim a Igreja e o Convento ficaram prontos, o Inquisidor Geral Zapata e os Inquisidores de Toledo idealizaram uma cerimônia de derrubada da casa. E no dia 6 de julho pela manhã uma procissão seguiu pelas principais ruas de Madri até a calle de las Infantas, quando após a leitura da sentença, sob o olhar de uma multidão de fiéis iniciou-se a destruição da casa ${ }^{216}$.

Sob a influência dos Inquisidores e dos desejos da rainha Isabel de Bourbon, em 12 de julho de 1632 Felipe IV determina

hacer en esa casa donde Nuestro Señor fué ofendido, una fundación, con que sea alabado, venerado y servido, para cuya ejecucíon pensará ese Consejo en los medios que podrían hallar para sacar con que llevar a efecto este intento ${ }^{217}$.

Ficou estabelecido que a patrona do templo expiatória fosse a rainha, e para a execução do projeto o monarca elegeu uma junta de ministros, que ficou conhecida como Junta de la fundación de la Reina Isabel. ${ }^{218}$ Assim mandou-se construir uma igreja para a Paciência de Cristo, e, após sete anos, Isabel de Bourbon concedeu à ordem Capuchinha a fundação de um convento no local ${ }^{219}$. A decisão desta outorga aos padres capuchinhos foi influenciada por Antonio Contreras, ministro do real Conselho e o conselheiro mais importante da Junta e também patrono de um convento desta ordem em Segóvia ${ }^{220}$

\footnotetext{
${ }^{215}$ GOMEZ DE MORA, Juan. Auto de la fé celebrado en Madrid ensta año de MDCXXXII, 1632, fol. $21 \mathrm{r}$ ${ }^{216}$ PULIDO SERRANO, Juan Ignacio. Injúrias a Cristo: religión, política y antijudaísmo en el siglo XVII. 2002, pp 273- 274.

${ }^{217}$ Carta de Felipe IV al Consejo (Simancas - Secretarías Provinciales. Sicilia. Leg 1343) Apud. CARROCERA, Buenaventura de. La provincia de Frailes Menores Capuchinos de Castilla. Vol I. (15731701), p. 152.

${ }^{218}$ PULIDO SERRANO, Juan Ignacio. Injúrias a Cristo: religión, política y antjudaísmo en el siglo XVII, 2002, p. 282.

${ }^{219}$ BARRIO MOYA, José Luis. Cristobal de Aguilera y el desaparecido Convento de los Capuchinos de la Paciencia de Cristo, de Madrid. Anales del Instituto de Estudios Madrileños, 1981,Tomo XVIII, p. 188; PULIDO SERRANO, Juan Ignacio. Injúrias a Cristo: religión, política y antjudaísmo en el siglo XVII, 2002, p. 318.

${ }^{220}$ PULIDO SERRANO, Juan Ignacio. Injúrias a Cristo: religión, política y antjudaísmo en el siglo XVII, 2002, p 318.
} 
A Ordem dos Frades Menores Capuchinhos é um ramo da Ordem de São Francisco, que teve origem no século XVI na Itália $^{221}$. Para a historiadora Anel Hernandez Sotelo, os capuchinhos buscavam o retorno ao franciscanismo medieval, e sua separação politica do ramo conventual aconteceu em 1619, mas na Espanha, durante os séculos XVII e XVIII receberam muitos favores e proteção da nobreza ${ }^{222}$.

Em 13 de dezembro de 1639, os padres capuchinhos inauguraram a capela primitiva com uma procissão solene que conduziu uma imagem de Cristo ao seu altar. Como o convento ainda não estava construído, os religiosos passaram a habitar algumas casas que já faziam parte do terreno do convento ${ }^{223}$. Em abril de 1642, o rei concedeu uma real cédula que mantinha Contreras como encarregado da construção do Convento e da igreja,

conforme a la traça que se a hecho de la Iglesia Capilla que esta firmada del Padre fray Alejandro de Valencia Provincial desta provincia de dha. Ordem y los padre fabriqueros de ella y del dho. Antonio Contreras y haviendose dado noticia de ello y ablado con el dho. xptoval. de Aguilera se encaragara de hacer la dha. obra por el deseo que tiene de acudir al servicio de dho. Convento y su devoción Como a echo hasta aquí por su parte se encargado de hacer dha. obra conforme y las condiciones... ${ }^{224}$

Por fim, em 17 de setembro de 1651, na festa das chagas de São Francisco ocorreu a translação do Santíssimo Sacramento do Santo Cristo para a nova igreja ${ }^{225}$. A igreja e o convento foram bastante ativos até o final do século XVIII, e desde 1663 também funcionou ali um seminário. Hoje, onde outrora ficava o edifício há a praça denominada Vazquéz de Mella, mas a Federação Estatal LGBT (Lesbianas, Gays,

\footnotetext{
${ }^{221}$ Em 1528 por meio da bula Religionis zelus do papa Clemente VII.

${ }^{222}$ HERNANDEZ SOTELO, Anel. ¿Quiénes son los capuchinos? Aportación historiográfica sobre los orígenes de una reforma franciscana. GRAFFYLIA. México, ano 6, $\mathrm{n}^{\circ}$ 10, 2009 p 118; HERNANDEZ SOTELO, Anel. Fora da Itália, o primeiro país a se estabelecerem foi na França, em missões para converter os protestantes. O primeiro contato com os espanhóis ocorreu na batalha de Lepanto, quando os padres capuchinhos foram convocados pelo papa para dar apoio espiritual nas embarcações espanholas. Nesta mesma apresentação, a professora Anel diz que a ideia do hábito com capuz e a barba seria uma dissimulação, típica do período, em que o monge se pretendia um alter franciscus e um alter christus. Conferência: La Construcción de la Imago Capuchina, Seminário de crónicas Franciscanas UNAM, apresentado em 11 de fevereiro de 2015. Acesso em: 9/12/2015. https://www.youtube.com/watch?v=u996fb5cw64\&list=PLKbeH5koX_VilFdeYwPm0IWJ9jVc-fSp

${ }^{223}$ CARROCERA, Buenaventura de. La provincia de Frailes Menores Capuchinos de Castilla. Vol I. (1573-1701). Administración de "El Mensajero Seráfico", 1949, p. 154.

${ }^{224}$ A.H.P.M. Prot ${ }^{\circ}$ 5354. Apud: BARRIO MOYA, José Luis. Cristobal de Aguilera y el desaparecido Convento de los Capuchinos de la Paciencia de Cristo, de Madrid.Madrid, 1981, p. 189.

${ }^{225}$ CARROCERA, Buenaventura de. La provincia de Frailes Menores Capuchinos de Castilla. Vol I. (1573-1701), p. 154.
} 
Transexuales y Bisexuales) e o Coletivo Gay de Madri reivindicam a mudança do nome da praça para Pedro Zerolo, um politico socialista morto em 2013, ativista e defensor dos direitos $\mathrm{LGBT}^{226}$.

\subsection{As imagens da Capela do Santíssimo Cristo da Paciência de Madri}

Quando as pinturas que ora estudamos foram encomendadas, já existia uma série de textos em que o suposto ataque e o milagre dele decorrente eram narrados. $\mathrm{O}$ primeiro apontamentos foram os depoimentos do pequeno Andresillo, que ocorreram entre 1630-1631. Mas o relato do milagre só apareceu em seu último depoimento, em 1631, para o comissário do Santo Ofício de Madrid, Juan de la Peña, no qual a criança apenas teria dito que o crucifixo havia se queixado. Em nenhum momento deste depoimento o pequeno diz que a imagem havia sangrado ${ }^{227}$. Após Andresillo ter narrado o feito prodigioso do crucifixo, os réus foram conduzidos a novos interrogatórios, e após meses de tortura, o milagre da fala de Cristo começa a surgir nos depoimentos de Elena Núñez. De acordo com sua declaração, o Cristo teria falado, também em reposta a um ataque em outra ocasião e lugar, em Portugal na cidade de Gradix ${ }^{228}$. Já Violante Méndez teria dito em seu interrogatório que o milagre teria ocorrido em $\mathrm{Madri}^{229}$, e Victoria Méndez teria relatado ao inquisidor as seguintes palavras professadas pelo crucifixo: ¿cómo me maltratáis y azotaís, no sabéis malditos que soy vuestros Dios? ${ }^{230}$.

\section{Narrativas textuais do milagre do Santissimo Cristo de la Paciencia de Madrid}

Mas as primeiras narrativas completas do ataque e do suposto milagre da calle de las infantas foram os sermões para os festivos de expiação do agravo e as Relações

\footnotetext{
226 Acesso em 9/12/2015 http://www.abc.es/madrid/20150722/abci-plaza-vazquez-mella-zerolo201507220950.html

${ }^{227}$ AHN Inq. Leg. 140 Caixa 2 Exp. 4h, Proceso de Miguel Rodriguez. As declarações de Andresilho estão anexadas ao processo de seu pai, Miguel Rodriguez.

${ }^{228}$ AHN Inq. Leg. 140 Caixa 2 Exp. 4f, Proceso de Elena Núñez. Apud: SERRANO, Juan Ignacio Pulido. Injúrias a Cristo: religión, política y antijudaísmo en el siglo XVII, 2002, p. 151.

${ }^{229}$ AHN Inq. Leg. 140 Caixa 1 Exp. 4d, Proceso de Violante Mendez. Apud: SERRANO, Juan Ignacio Pulido. Injúrias a Cristo: religión, política y antijudaísmo en el siglo XVII, 2002, p. 151.

${ }^{230}$ AHN Inq. Leg. 140 Caixa 1 Exp. 4c, Proceso de Victoria Mendez fol. 111vto. Apud: SERRANO, Juan Ignacio Pulido. Injúrias a Cristo: religión, política y antijudaísmo en el siglo XVII, 2002, p. 151.
} 
do Auto de Fé de 1632. Estes textos, a despeito de pertencerem a gêneros distintos, estavam carregados de topoi antijudaicos, de apelos para o compromisso dos cristãos para com a fé católica ${ }^{231}$ e de elogios às ações da Inquisição, e desta forma contribuíram para a propagação desta memória ${ }^{232}$.

As descrições do auto de fé de 1632 são intituladas: Aqui se contiene lo que sucedio en la casa de unos Hebreos, com uma figura de Christi que azotaran. Como fueron descibiertos y el castigo que les dieron, 1632 de autor anônimo, Relacíon del Auto de la fé, que se celebró en Madrid, Domingo a quatro de Julio de 1632, também de autor anônimo, junto com o escrito por Juan Gomez de Mora, o arquiteto responsável pela construção do tablado do Auto de 1632, denominado: Auto de la fé celebrado en Madrid ensta año de MDCXXXII, esta última considerada a versão oficial pelas autoridades espanholas $^{233}$. São relatos muito semelhantes, de caráter descritivo e detalhado dos acontecimentos daquele verão de 1632, que falam da construção do tablado, a procissão da Cruz Verde ${ }^{234}$, a Missa, o balcão do rei, todos os nobres e clérigos importantes, os condenados com suas culpas e penas, enfim todos os detalhes daquela festividade. Para Pulido Serrano, a função principal destes relatos era o de difundir a mensagem política, um instrumento utilizado para comunicar à sociedade as ideias inquisitoriais, ou seja, funcionado como uma peça publicitária da Inquisição. ${ }^{235}$ Sobre o agravo e o suposto milagre, ele os descreve quando narra o momento da leitura da sentença de Miguel Rodriguez:

El quinto fue puesto para leerle su sentencia, residente en Madrid, Miguel Rodriguez, Portugues, Judaizante, natural Ferrarin de edad de sessenta años; fue relaxado en persona, y que la casa donde vivia fuesse derribada por el suelo, y que en ella se pusiesse um Padron donde diga la causa, que fu ela mayor atrocodad

\footnotetext{
231 "Chistianos fieles Catolicos Españoles, estes son los villanos a quién se quitó la viña, por no hacer fruto y se nos dio a nosostro". PARVICINO Y ARTEGA, Hortencio Felix. Jesuchristo desagraviado o Oracion evangélica de los ultrages de Iesucristo...nueva i sacralegamente repetidos por unos hebreos. 1633 , fol $2 \mathrm{v}$.

${ }^{232}$ Superando o caráter efềmero destes tipos de acontecimento. SERRANO, Juan Ignacio Pulido. Injúrias a Cristo: religión, política y antijudaísmo en el siglo XVII, 2002, p 219.

${ }^{233}$ PULIDO SERRANO, Juan Ignacio. Injúrias a Cristo: religión, política y antijudaísmo en el siglo XVII, 2002, p. 218.

${ }^{234}$ GOMEZ DE MORA, Juan. Auto de la fé celebrado en Madrid ensta año de MDCXXXII, 1632, fol $4 \mathrm{r}$.

${ }^{235}$ PULIDO SERRANO, Juan Ignacio. Injúrias a Cristo: religión, política y antijudaísmo en el siglo XVII, 2002, p. 219.
} 
que jamas se ha visto, açotando el y su mujer, y otros, uno Santo Christo, que derramó sangre, $\mathbf{y}$ hablo tres vezes, y después le quemaron. ${ }^{236}$

Quanto aos demais réus, ele apenas descreve seus trajes e os eclesiásticos que os acompanham.

De maneira distinta, os sermões dão maior ênfase ao ataque e ao milagre. Juan Antonio de la Peña ${ }^{237}$ escreveu em 1632 o Discurso en exaltación de los improperios que padeció la Imagen de Christo N.S. a manos de la perfidia Judaica. Con relacion de la magnifica Octava, Sermones, Letras y Procesiones que estos católicos intentos hizo en Real Convento de las Descalzas la Serenísima y Religiosísima Sor Margarita de la Cruz. Esta obra contém os oito sermões pregados na primeira festa de desagravo, que ocorreu entre 16 e 23 de julho de 1632, no Convento de las Reales Descalzas. Nessa festa estiveram presentes Felipe IV e toda a família real, o inquisidor geral Zapata, o Conde Duque de Olivares e todos os demais membros importantes da nobreza castelhana. Não podemos deixar de ressaltar que Juan Antonio de la Peña fora um representante oficial da Igreja Romana e da Inquisição Espanhola, e quando escreve um sermão cujo tema é o ataque e o milagre da imagem, a despeito de ser necessário um conhecimento de Retórica para compreender seu discurso, parece-nos claro quando ele diz:

Açotaron esta santa Imagen muchas vezes, e en tã repetidas, quanto sufridas injurias, quexose Christo y habloles. Los açotes animaró la voz. Que fue esto? Digo, que castigarles de contado su desacato y desverguença. Cobro osadia su atrevimento en la insensibilidad de la Imagen viendo que nen le podía doler, ni se podía quexar ${ }^{238}$

...Pues vea el judío correr la sangre a la Imagen, oiga hablar con animadas voces para que a fuerza de tocar el milagro cobre la fe perdida... ${ }^{239}$

que as imagens religiosas seriam capazes de atuar em prol da fé.

Os sermões Sermón de los desagravios de Jesuscristo, posteriores glórias de su Cruz y feliz escândalo del judio, de Francisco de Boyl; Jesuchristo desagraviado o

\footnotetext{
${ }^{236}$ GOMEZ DE MORA, Juan. Auto de la fé celebrado en Madrid ensta año de MDCXXXII, 1632, fol $14 \mathrm{v}$.

${ }^{237}$ Responsável pelo último depoimento de Andresillo.

${ }^{238}$ PEÑA, Juan Antonio de la. O Discurso en exaltación de los improperios que padeció la Imagen de Christo N.S. a manos de la perfidia Judaica, 1632 , fols $14 \mathrm{v}-15 \mathrm{r}$.

${ }^{239}$ PEÑA, Juan Antonio de la. O Discurso en exaltación de los improperios que padeció la Imagen de Christo N.S. a manos de la perfidia Judaica, 1632, fol $17 \mathrm{r}$.
} 
Oracion evangélica de los ultrages de Iesucristo...nueva i sacralegamente repetidos por unos hebreos, de Hortencio Felix Paravicino y Arteaga; e Sermón predicado en la solene octava que la Congregacios del Santo Ofício celebró en el real Convento de S. Domingo à los desagravios de Christo ofendido en su Imagen, de Francisco Soria, foram compostos para a festa de desagravo organizada pelos membros da Confraria San Pedro Mártir em abril de 1633 no Convento de San Domingo el Real. Esta festa, também de caráter oficial contou a presença de Felipe IV e sua família, os membros mais importantes da Inquisição e da corte ${ }^{240}$. Destes tivemos acesso somente aos dois últimos.

Paravicino y Arteaga, para compor seu sermão, buscou na história do cristianismo casos semelhantes ao ocorrido em Madri, relatando um que teria ocorrido em Constantinopla no ano de $446^{241}$, outro em $560^{242}$, também o famoso caso do Cristo de Beirute ${ }^{243}$ e assim, como La Peña, justifica o poder das imagens milagrosas.

Francisco Soria, quando trata da hierofania do crucifixo, apela para bases teológicas da presença de Deus em Cristo: se Cristo é a Imagem de Deus, logo um crucifixo pode ser a Imagem de Cristo:

Esto mismo deve hazer el Hijo, si ha de ser amor cõpetidor de su Padre, ha de dar un hijo para que se le maltraten, afrenten, açoten y quiten la vida, pero esto no puede ser esto es imposible, porque el Hijo no tiene hijo, el Hijo es engendrado, y pero no engendra. Pues que remedio? Que de su imagen para que la arrastren, la açoten y quiten la vida, est es, que la quemen, que el fuego es muerte de madero, y hecho esto, habrá cumplido con sus obligaciones, como si hubiera dado un hijo [...] y asi los açotes que dieron en la Imagen, suplieron por los que pudieran dar al hijo. ${ }^{244}$

\footnotetext{
${ }^{240}$ PULIDO SERRANO, Juan Ignacio. Injúrias a Cristo: religión, política y antijudaísmo en el siglo XVII, pp. 243-246.

241 "El año de 446.a primero de Noviembre, hirio un loco destos en Constantinopla con un cuchillo en el rostro à un Cristo. Començo a currer del sangre: i viendose medroso cubrir della, le arrojo en un poço...". PARVICINO Y ARTEGA, Hortencio Felix. Jesuchristo desagraviado o Oracion evangélica de los ultrages de Iesucristo...nueva i sacralegamente repetidos por unos hebreos. 1633 , fol $8 \mathrm{v}$.

${ }^{242}$ PARVICINO Y ARTEGA, Hortencio Felix. Jesuchristo desagraviado o Oracion evangélica de los ultrages de Iesucristo...nueva i sacralegamente repetidos por unos hebreos. 1633, fol 9r.

${ }^{243}$ PARVICINO Y ARTEGA, Hortencio Felix. Jesuchristo desagraviado o Oracion evangélica de los ultrages de Iesucristo...nueva i sacralegamente repetidos por unos hebreos. 1633, fol 10v.

${ }^{244}$ SORIA, Francisco. Sermón predicado en la solene octava que la Congregacios del Santo Oficio celebró en el real Convento de S. Domingo à los desagravios de Christo ofendido en su Imagen, 1633 , fol $7 \mathrm{v}-8 \mathrm{r}$.
} 
Por meio da leitura destes sermões podemos perceber que, nos meios eclesiásticos, nesse momento havia uma anuência de que as imagens religiosas poderiam manifestar-se milagrosamente e atuar como defensoras da fé católica. E que também tais sermões poderiam servir como fonte inspiradora para a composição pictórica das pinturas aqui analisadas.

A primeira figuração do agravo e do suposto milagre que temos notícia é uma gravura de Jean de Coubers (Figura 13), para o frontispício do livro de sermões Vespertinas de los opróbios de la Passion de Cristo causados de la casi eternalmente ingrata nación hebrea, en modo de diálogos para las tardes de los domingos de la quaresma, ocasionados de lo que se predicó por las mañanas de Francisco de Rojas Nieto, impresso em 1634. Apesar do frontispício da obra, o texto trata mais da vida de Cristo e da "maldade" da fé hebraica. 


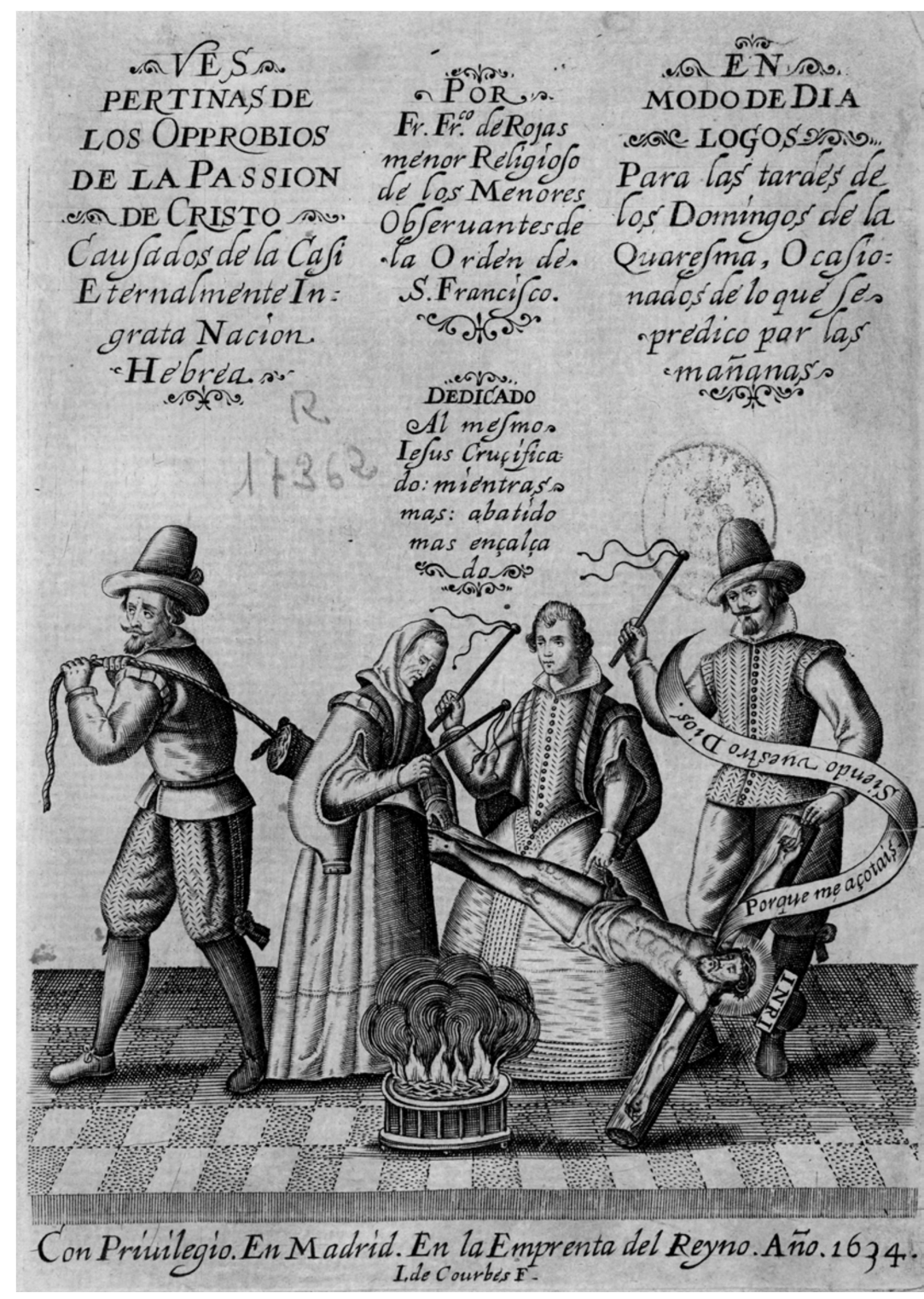

Figura 13 - frontispício Vespertinas de los opróbios de la Passion de Cristo, 1634, gravura, $17,5 \mathrm{~cm}$ x $12 \mathrm{~cm}$, Jean de Coubers, Biblioteca Nacional da Espanha [R-14461].

Já as imagens que analisamos em nossa dissertação, como já dissemos na introdução, foram encomendadas para as paredes da Igreja do Convento do Cristo da Paciência de Madri, e executadas por pintores pertencentes à escuela madrileña, Francisco de Rizi, Francisco Fernandez, Francisco Camilo e Andrés de Vargas. 


\section{Os pintores}

Os pintores espanhóis do século XVII, em sua grande maioria (havia exceções como Velásquez, claro) não alcançaram patamares sociais como os mestres italianos. E segundo Alfonso E. Pérez Sanchez, a despeito das alegações de que a pintura seria uma arte liberal, pesavam sobre os mestres espanhóis o preconceito dos ofícios baixos e servis $^{245}$.

Parece-nos que esta era a situação dos pintores que executaram as obras para o antigo Convento dos Capuchinhos de Madri. Sendo pintores de pouca fama, logo suas biografias são escassas. A obra de referência sobre a vida destes artistas é o Tomo III do tratado de Antonio Palomino de Castro y Velasco, El Museo Pictorico, y Escala Optica, El Parnaso español pintoresco laureado.

Francisco Fernandez (1605-1657) foi discípulo de Vicente Carducho e realizou o desenho de algumas gravuras do Dialogos de las Pinturas, tratado de seu mestre. Sabemos que executou algumas pinturas, como retratos dos reis, Dom Bermudo III de Leon e Dom Fernando I de Castela, para o salão de Comédias de Alcázar de Madri, destruído em 1734. Também pintou obras para o Convento de La Victória, além da pintura para o Convento dos Capuchinhos da Paciência ${ }^{246}$. Das poucas obras que podemos assegurar a autoria de Fernadez é o óleo sobre tela Saúl amenazando a Davis com su lanza [4/98], do Museu de Belas Artes de Valencia ${ }^{247}$.

Francisco Rizi (1614-1685), o mais afamado dos quatro pintores responsáveis pelas obras do Convento da Paciência, foi também discípulo de Vicente Carducho. Um dos pintores mais favorecidos pelo mestre, iniciou seus trabalhos para a corte em 1639. Sua ascendente presença no Palácio e nos meios eclesiásticos madrilenos lhe proporcionou muitos trabalhos e em 1653 foi nomeado pintor oficial da Catedral de Toledo. Em 1656 obteve o título de pintor do rei. Além das pinturas também executou muitas decorações efêmeras, como a chegada a Madri da rainha Mariana de Áustria em

\footnotetext{
${ }^{245}$ PÉREZ SÁNCHEZ, Alfonso E. Pintura Barroca en España: 1600-1750. Madrid: Cátedra, 2010, p 17.

${ }^{246}$ MUSEU DO PRADO. Coleccion. www.museodelprado.es/enciclopedia/enciclopedia-online/voz/fernandez-francisco/, Acesso em 19/11/2015

${ }^{247}$ PÉREZ SÁNCHEZ, Alfonso E. Pintura Barroca en España: 1600-1750. 2010, p 92.
} 
1649, bem como numerosos cenários e maquinarias de palco para o teatro do palácio do Bom Retiro, do qual foi diretor por anos. Afora as duas pinturas para o convento dos Capuchinhos da Paciência de Madri (Profanação ao crucifixo e Espólio de Cristo), foram de sua autoria grandes obras como o Retablo de San Pedro para a Igreja de São Pedro Apóstolo de Fuete de Saz, o retábulo Capilla del Milagro (1678) para a Descalzas Reales em Madri e o grandioso Auto de Fe en la Plaza Mayor de Madrid [P1126] de 1683, pertence ao Museu do Prado. ${ }^{248}$

Francisco Camilo (1615-1673), filho e enteado de pintores, também iniciou jovem sua trajetória de pintor, e se estabeleceu em Madri em 1639 junto com Rizi. Nunca obteve o título de pintor do rei, mas executou uma série de trabalhos para Felipe IV, como as cenas da Metamorfose de Ovídeo para a Galeria de Oeste do Palácio de Alcázar, por ocasião da segunda boda do rei, em 1649, como também a pintura para o Convento dos Capuchinos da Paciência de Madri. A maioria de suas telas foi de temática religiosa, como San Carlos Borromeo y los apestado, para a nova Catedral de Salamanca, para as Carmelitas descalças pintou em 1651 o Martírio de San Bartolomé [P623] e San Jerónimo azotado por los ángeles [P2966] hoje no Museu do Prado ${ }^{249}$.

Andrés de Vargas (1613-1674) nasceu em Cuenca e muito jovem foi enviado a Madri, onde aprendeu pintura junto a Camilo, seu grande amigo. Sua primeira obra conhecida foi a Transverberación de Santa Teresa (1644), para o convento das Carmelitas de São José de Guadalupe. Em 1651 finalizou a pintura Martírio num Braseiro, para a capela do convento dos Capuchinhos da Paciência, obra destruída em um incêndio quando exposta em Porriño em 1976. Em 1652 Vargas retorna a Cuenca com o encargo da decoração da Capela de Nossa Senhora do Sacrário da Catedral da cidade, lá se estabeleceu e deu continuidade à sua carreira de pintor até sua morte. ${ }^{250}$

\footnotetext{
248 PÉREZ SÁNCHEZ, Alfonso E. Pintura Barroca en Enspaña : 1600-1750. 2010, pp 282-286; MUSEU DO PRADO. Coleccion. htwww.museodelprado.es/enciclopedia/enciclopedia-on-line/voz/rizifrancisco/?no cache $=1$, Acesso em 23/11/2015.

${ }^{249}$ PÉREZ SÁNCHEZ, Alfonso E. Pintura Barroca en Enspaña : 1600-1750. 2010, pp 299-303 ; MUSEU DO PRADO. Coleccion. www.museodelprado.es/enciclopedia/enciclopedia-on-line/voz/camilofrancisco/?no cache $=1$, Acesso em 23/11/2015.

${ }^{250}$ BARRIO MOYA, José Luis. El pintor conquense Andrés de Vargas y una obra suya en Guadalajara. Wal-al-Hayara: Revista de Estudios de Guadalajara. Guadalajara, 1991, nº18, pp 463-473.
} 
Parece-nos muito difícil determinar o grau de independência criativa dos artistas espanhóis do século XVII para que assim possamos identificá-los como criadores das pinturas que ornaram a Capela do Convento dos Capuchinhos de Madri. Devemos lembrar que não existia um mercado consumidor de pinturas domésticas na sociedade espanhola seiscentista, o que poderia ampliar as possibilidades criativas dos $\operatorname{artistas}^{251}$ e os obrigava a trabalhar por encomenda. Desta feita, podemos inferir a importância do papel comitente nas decisões temáticas e formais (materialidade plástica), das obras encomendadas. O historiador da Arte Alfonso Perez Sanches aponta que a maior clientela seriam as instituições religiosas e a corte, e em menor escala a existência de alguns clientes particulares ${ }^{252}$.

A Igreja Contrarreformista, como já apontamos aqui, fora um setor de extremo poder na Espanha do Século de Ouro, e impulsionou a fundação de novos conventos e capelas, e a exaltação dos seus santos proporcionou um amplo campo de trabalho para pintores, arquitetos, talhadores, etc. As grandes catedrais passaram a ter um posto para um pintor oficial, e os cabildos catedrales custeavam obras de manutenção e para as celebrações, como as arquiteturas efêmeras realizadas para a semana santa ${ }^{253}$. Contudo, sem dúvida o maior cliente deste período foram as ordens religiosas:

En el ámbito conventual se encuentra seguramente lo más expresivo de la pintura española del siglo de oro. Se ha señalado el papel fundamental que en la vida nacional desempeñan las órdenes religiosas [...]. No menos significativo es el representado como cliente artístico en todos los niveles, y se ha podido afirmar que 'todos los pintores de importancia, con la única excepción de Velázquez, contribuyeron al menos una vez a los encargos de ciclos en los que se representaban la historia u los miembros más ilustres de estas instituciones, ${ }^{254}$

Para a Ordem dos Capuchinhos da Espanha, além dos mestres que executaram as pinturas que aqui pesquisamos, trabalharam artistas como Murilo, Francisco Ribalta, Antonio de Pereda, Carreño de Miranda, Francisco de Solís, Garcia Reinoso entre outros.

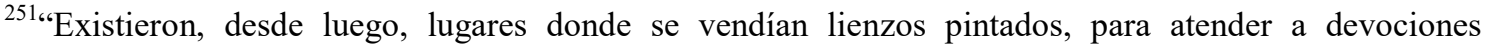
domésticas, simples deseos de decoración o de posesión de modestas imágenes de poder real, pero todos los testimonios apuntan a que estas 'tiendas' tenían un carácter menos, y eran consideradas como algo bajo, sin calidad ni prestigio, indignas de un verdadero artista." SÁNCHEZ, Alfonso E. Pérez. Pintura Barroca en Enspaña : 1600-1750, 2010, p 29

${ }^{252}$ PÉREZ SÁNCHEZ, Alfonso E. Pintura Barroca en Enspaña: 1600-1750, 2010, pp. 31-37.

${ }^{253}$ PÉREZ SÁNCHEZ, Alfonso E. Pintura Barroca en Enspaña: 1600-1750, 2010, p 32.

${ }^{254}$ PÉREZ SÁNCHEZ, Alfonso E. Pintura Barroca en Enspaña: 1600-1750, 2010, p 33.
} 
Sobre a encomenda das pinturas do Convento dos Capuchinhos da Madri, de acordo com a obra La Nueva Jerusalen de Matheo de Aguiano, a rainha Isabel de Bourbon teria deixado Contreras encarregado da encomenda das pinturas:

la Reyna nuestra señora Doña Isabel de Borbon, que la tomo por cuenta, y en su muerte, la dexo encomendada al señor Don Antonio de Contreras, Cavallero del Orden de Calatrava, del Consejo, y Camara de su Magestad, que hizo hazer este Convento, Quadros de Pintura, y Letrero, para memoria de todo. ${ }^{255}$

Porém, apesar deste excerto, não encontramos outros documentos que trataram da encomenda das pinturas, o que nos deixa impossibilitados de conhecer os reais comitentes, se foram os padres Capuchinhos, a junta chefiada por Antonio Contreras, mesmo se houve alguma influência de Felipe IV ou dos membros da Inquisição.

255 ANGUIANO, Mateo de. La nueva Jerusalen en que la perfidia hebraica reitero con nuevos ultrages la passion de Christo en su ss. imagen. del Crucifixo de la Paciencia en Madrid, 1709, p. 299. 


\section{Os agressores do Cristo da Paciência}

A base para a conformação da lenda do milagre do Cristo da Paciência, assim como da construção do templo e encomenda das imagens, teve sua origem na denúncia contra três famílias de cristãos-novos portugueses residentes em Madri. Eles denunciados ao Tribunal de Santa Inquisição de Toledo em 1630 teriam chegado à Espanha há pouco tempo. Miguel Rodriguez e sua família se estabeleceram em Madri em 1629, em uma pequena casa na calle de las Infantas, onde meses depois também vieram a residir Fernán Baez e sua esposa, e bem próximo, na mesma rua, a viúva Beatriz Núñez com seus filhos estabeleceram residência. Estas três famílias vieram para Madri, assim como muitas outras famílias de conversos portugueses, em busca da esperada estabilidade que a administração do valido do rei, Conde Duque de Olivares, havia proporcionado aos criptojudeus portugueses.

\subsection{A política econômica do Conde Duque de Olivares}

Antes mesmo de findar o século XVI, a Espanha já começara a sentir os sintomas da crise:

descenso de la población, contracción económica, graves perturbaciones monetarias y crediticias, extrema penuria hacendística, inmenso desorden financiero, fuerte ascenso de los servicios y destructor recrudecimiento de la presión fiscal ${ }^{256}$

Essa crise, segundo Benjamin González Alonso, não era superficial e nem passageira $^{257}$, e o seu reconhecimento oficial ocorreu em 1618 com o pedido ao Conselho de Castela sobre sua opinião a respeito das causas e os remédios para crise que se instalara. Este respondeu em janeiro de 1619, com a afirmação de que o dano era "grande y universal", mas sem grandes propostas para solucionar o colapso econômico

\footnotetext{
${ }^{256}$ GONZÁLEZ ALONSO, Benjamin. El Conde Duque de Olivares y la administración de su tempo. In: LA ESPAÑA DEL CONDE DUQUE DE OLIVARES: ENCUENTRO INTERNACIONAL SOBRE LA ESPAÑA DEL DEL CONDE DUQUE DE OLIVARES, Toro: 1989. Anais...Valladolid: Universidad de Valladolid, 1990, p 282.

${ }^{257}$ GONZÁLEZ ALONSO, Benjamin. El Conde Duque de Olivares y la administración de su tempo, 1990, p. 282.
} 
instalado. E em meio à crise, com a morte de Felipe III em 1621, Felipe IV é coroado e entra em cena Gaspar de Guzman, o Conde Duque de Olivares (1578-1645), que com suas manobras administrativas pretendia restaurar as contas da monarquia espanhola ${ }^{258}$.

A insatisfação dos cristãos-velhos espanhóis com os criptojudeus portugueses ocorreu, em grande parte, por causa destas medidas políticas e econômicas do CondeDuque de Olivares. Desde o final do século XVI, a Coroa passou a contar com empréstimos (asientos) de banqueiros cristãos-novos portugueses, o que contribuía para manter a política expansionista espanhola ${ }^{259}$. O Conde-Duque então, para ampliar os empréstimos, tenta suavizar a política de limpeza de sangue, com o intuito de atrair ainda mais os banqueiros portugueses. Em 1622 inicia-se uma série de negociações com a gente da nação ${ }^{260}$ que resultou em 1627 no perdão geral com a liberação dos cárceres da Inquisição portuguesa; a liberação de casamento entre cristãos-novos e velhos; a liberdade de movimento na Península Ibérica; a possibilidade de se instalar em Castela e em Sevilha, para participar das negociações comerciais com as Índias. Deve ficar claro que todas estas "liberdades" ocorreriam mediante o asiento de uma grande quantia de dinheiro $^{261}$. Estas medidas trouxeram benefícios imediatos à monarquia e a possibilidade de romper com os credores genoveses ${ }^{262}$. Olivares conseguiu pouco a pouco introduzir alguns negociantes portugueses nos assuntos da Real Fazenda e protegê-los dos cárceres da Inquisição Espanhola ${ }^{263}$, uma troca vantajosa tanto para Coroa como para os banqueiros portugueses. E assim, a Espanha do século XVII recebe em suas terras alguns ricos homens de negócios e também uma massa de pequenos comerciantes criptojudeus portugueses ${ }^{264}$.

\footnotetext{
${ }^{258}$ GONZÁLEZ ALONSO, Benjamin. El Conde Duque de Olivares y la administración de su tempo, $1990, \mathrm{p} 282$.

${ }^{259}$ Sobre o investimento dos banqueiros portugueses antes da politica olivariana ver: CARRASCO VASQUEZ, Jesus Antonio. La minoria judeoconversa en la época del Conde Duque de Olivares, auge y ocaso de Juan Núñez Saraiva (1585-1639), 2004, pp. 168-176.

${ }^{260}$ Outra forma de denominar os criptojudeus

${ }^{261}$ MARTÍN, Manuel Urí. Banqueros Portugueses em Castilla: acerca de um texto antimarrano de Quevedo. In: ACTAS XIII CONGRESO ASOCIACIÓN INTERNACIONAL HISPANISTAS (Tomo I). Madrid, 1998, Atas... Madrid: Castalia, 2000, p. 792.

${ }^{262}$ VAZQUEZ. Jesus Antonio Carrasco. La minoria judeoconversa en la época del Conde Duque de Olivares. Auge y ocaso de Juan Núñez Saraiva (1585-1639), 2004, pp. 280,

${ }^{263}$ MARTín, Manuel Urí. Banqueros Portugueses em Castilla: acerca de um texto antimarrano de Quevedo, 2000, p.793.

${ }^{264}$ FERNANDEZ MOSQUERA, Santiago. Situácion e Contexto de la Execracíon de los judios de Quevedo STUDIA AUREA: ACTAS DEL III CONGRESO DE LA AISO. Toulouse: 1993. Atas... Navarra: GRISO (Grupo de Investigación Siglo de Oro Universidad de Navarra), 1996, p. 171.
} 
Não obstante, estas medidas não foram bem recebidas por parte da população e principalmente pela Igreja espanhola, o que colocou os conversos portugueses residentes em Espanha sob a total vigilância da população e da Inquisição espanhola, além de colocar em xeque a administração do Conde-Duque de Olivares ${ }^{265}$.

Quando os cristãos-novos portugueses chegaram em terras espanholas, segundo Pulido Serrano, por causa da crença de que em seus ritos e cerimônias secretos eles praticariam sacrilégios contra crucifixos, passaram a ser culpados por todos os supostos ataques a objetos visuais religioso. O que pode ser exemplificado com um caso de 1625 , quando na região de Toledo teria ocorrido um agravo contra 14 cruzes que haviam sido colocadas na Via Sacra, por ocasião de uma procissão, que foram derrubadas e chicoteadas. Sobre este sacrilégio, um ministro da Inquisição em correspondência escreveu: "hay muchos portugueses con familias enteras..., que se puede temer de ellos harán hecho este delito y todos los que sucedieren semejantes."266. Ainda podemos citar outra correspondência do Inquisidor Geral, Andrés Pacheco de Cárdenas (1555-1626), a Felipe IV:

diversas veces he hablado sobre ello al Presidente del Consejo y entiendo lo tendrá advertido, y dos días a traté con él acerca de lo mismo y li dije algunas cosas en particular, porque el daño pasa tan adelante que hay indicios de que tienen lugares secretos donde se juntan a hacer sus ritos como en Sinagoga y injuriar sacrílegamente imágenes de Cristo Nuestro Señor ${ }^{267}$.

\subsection{As famílias condenadas ${ }^{268}$}

E foi nestas circunstâncias, um momento crítico para os conversos portugueses, que as três famílias estabeleceram-se em Madri. Estamos falando de um modelo

\footnotetext{
265 MARTÍN, Manuel Urí. Banqueros Portugueses em Castilla: acerca de um texto antimarrano de Quevedo, 2000. p.790-799.

${ }^{266}$ PULIDO SERRANO, Juan Ignacio. Injúrias a Cristo: religión, política y antijudaísmo en el siglo XVII, 2002, pp 138-139

${ }^{267}$ AHN Inq. lib. 534. Fol.143. Madrid, 23 de mayo de 1624. Apud. PULIDO SERRANO, Juan Ignacio. Injúrias a Cristo: religión, política y antijudaísmo en el siglo XVII, 2002, p. 139.

${ }^{268}$ A maior parte das informações sobre as famílias condenadas foram retiradas da obra Injurias a Cristo de Juan Inacio Pulido Serrano, que por sua vez as cotejou nos Processos da Inquisição de Toledo (AHN. Inq. Leg. 140. Caja 1 e 2). Tivemos acesso aos processos, porém devido ao seu extenso tamanho, ao tempo escasso de nossa estadia em Madri e ao alto custo para a reprodução eletrônica, decidimos nos debruçar de forma mais eficiente sobre os depoimentos de Andressillo, que foi fundamental para a condenação e que diretamente trata do milagre do crucifixo.
} 
familiar cujas características eram comuns entre os negociantes judeus conversos portugueses mais simples:

familias extensas con un gran número de hijos; los miembros de la familia desperdigados por la geografía peninsular, e incluso a veces por tierras más lejanas; todos ellos unidos por una fuerte solidaridad interna a pesar de la distancia que los separaba. Y sobre todo, un modelo familiar caracterizado por desarrollar estrategias matrimoniales guiadas principalmente por criterios de oficio, y de forma secundaria por criterio de sangre ${ }^{269}$

Miguel Rodriguez e Fernán Báez desde sua adolescência trabalhavam como vendedores de lenços, caixeiros viajantes, trabalho que os obrigara a viver entre terras portuguesas e castelhanas. Segundo declaração à Inquisição, Miguel Rodriguez nasceu em Ferreira e aos 14 anos teria aprendido a ler, escrever e manter-se sobre os preceitos religiosos do judaísmo e aos 15 foi pela primeira vez a Madri para trabalhar. Casou-se aos 35 anos, em Viseu, com a jovem cristã-nova Isabal Núñes Alvares. Manteve-se viajando para vender seus panos até ter as notícias das politicas de aceitação dos conversos portugueses em Castela e decidir-se estabelecer com sua família em Madri, quando já tinha mais de 60 anos. O português Fernando Báez, natural de Torre de Moncorvo, também se casou em Viseu com Leonor Rodrigues e decidiu viver em Madri com toda sua família em 1629, quando já contava com mais de 60 anos.

Beatriz Núñez, quando chegou a Madri, tinha 60 anos e era viúva de Domingos Luis, também vendedor de panos. Importante ressaltar o papel que as mulheres exerceram entre essas famílias portuguesas, cujos maridos passavam longas temporadas ausentes por causa de seu trabalho. Elas eram encarregadas de administrar a renda da família e a educação dos filhos, logo eram as responsáveis pela educação religiosa e pela manutenção da lei de Moisés no seio familiar. O que não seria diferente com Beatriz Núñez, que teria ensinado a religião e os rituais judaicos para seus filhos ${ }^{270}$.

É certo que tal fé seria exercitada em âmbito interno, pois todos eram conversos e aos olhos dos demais cristãos e da Igreja estas famílias praticavam a fé católica, batizando seus filhos, frequentando missas, comungando, respeitando o Cristo,

${ }^{269}$ PULIDO SERRANO, Juan Ignacio. Injúrias a Cristo: religión, política y antijudaísmo en el siglo XVII, 2002, pp. 117-118.

${ }^{270}$ As mulheres eram as responsáveis pela instrução religiosa das crianças e das jovens mulheres, e os adolescentes meninos amadureciam suas crenças em suas viagens, quando estabeleciam contatos com outros conversos que também procuravam manter suas práticas e rituais judaicos. 
os santos e suas imagens. Além disto, ressalvas são sempre prudentes, se estes pessoas acobertavam sua verdadeira fé com as práticas sociais dissimuladas, não podemos afirmá-lo categoricamente, pois as fontes que analisamos são resultado de dois anos de investigação da Inquisição de Toledo, na qual os réus permaneceram encarcerados e foram torturados. Assim, não podemos tomar como verdade absoluta tais depoimentos, pois essas fontes foram escritas pelos inquisidores, cujo prejulgamento vinha sendo conformado por séculos. Como já discutimos no capítulo anterior, devemos ter em mente tais prejulgamentos ao tratar destas fontes, principalmente no que tange à prática religiosa dos acusados, pois a historiografia aponta para a existência de conversões sinceras como também para aqueles conversos que tentaram de alguma forma manter a tradição judaica no seio de suas familiais. Durante a leitura de um dos processos, chamaram-nos a atenção os apelos que Victória Méndez, filha de Beatriz Núñez, teria feito ao ser torturada: "Virgen Santíssima, ayudadme; Espiritu Santo consolador, ayudadme; Soledad de La Virgen, socorredme, Virgen Santíssima del Rosário..."271. Ora, se dermos fé ao que está registrado nos autos, seria no mínimo inusitado da suplicante rogar à Virgem, em um momento de tamanha angústia, se não lhe dedicasse fé verdadeira. Por outro lado, se tal invocação à Virgem foi antes uma interpretação ou deliberada criação do redator do processo que uma descrição fidedigna do ocorrido, não deixa de ser contraditório à ideia de serem os acusados "maus cristãos".

Assim como as três famílias citadas, a malsin Juana Silva também era portuguesa e vivia no mesmo bairro que as famílias condenadas. Ela era próxima da família de Beatriz Núñez, e seria amante de seu filho, Simón Núñez, quando teria descoberto que ele e sua família praticavam em segredo a lei de Moisés e resolveu denunciá-los a Santa Inquisição, em 12 de junho de 1630, dirigindo-se ao conselheiro inquisitorial Pedro Pacheco ${ }^{272}$. Apesar de conhecer bem somente a família de Beatriz Núñez, Juana delata uma série de pessoas como as famílias de Miguel Rodriguez e de Fernán Báez. Após serem conduzidos aos cárceres de Toledo acabaram eles mesmos

\footnotetext{
${ }^{271}$ AHN Inq. Leg. 140. Proceso contra Victoria Méndez, fols. 96-97. Apud. PULIDO SERRANO, Juan Ignacio. Injúrias a Cristo: religión, política y antijudaísmo en el siglo XVII, 2002, p. 121.

${ }^{272}$ PULIDO SERRANO, Juan Ignacio. Injúrias a Cristo: religión, política y antijudaísmo en el siglo XVII, 2002, p. 126.
} 
denunciando outros portugueses e gerando pânico nas comunidades conversas de Madri, o que teria levado ao assassinato de Juana Silva em 30 de agosto do mesmo ano ${ }^{273}$.

\subsection{Andresillo: poca razón y capacidad, como tontillo ${ }^{274}$}

André Núnez, o filho mais novo de Miguel Rodriguez e Isabel Álvarez Núnez, teria seis anos quando foi interrogado pelo Inquisidor Juan Dionisio Fernández Portocarrero $^{275}$. As circunstâncias que levaram o menino a ser interrogado são muito obscuras. Parece que quando seus pais foram conduzidos ao cárcere de Toledo, somente teriam se preocupado com duas filhas Beatriz Enríques de 16 anos e Ana Rodríguez de 12, as quais ficaram sob a tutela de seu tio Francisco Vasquez ${ }^{276}$. Essa informação não deixa de ser curiosa, pois teriam se preocupado somente com as filhas de 12 e 16 anos, deixando o pequeno à mercê das ruas. O que consta é que o menino foi amparado por uma mulher que o levou a um mestre de seda, Agunstín de Vergara y Viescas, para que o acolhesse em troca de trabalho. Então Viescas, ao perguntar-lhe porque estava só nas ruas de Madri, recebera a resposta de que estava sozinho, pois seus pais haviam sido presos pela Inquisição de Toledo porque "azotaban um Cristo"277. Assustado o mestre de seda resolveu comunicar o relato do menino à Inquisição.

Deste modo Andresillo foi conduzido à presença de Portocarrero, que o interrogou perguntando se o garoto sabia por que seus pais estavam presos, e ele teria respondido:

los prendieron porque no comían tocino, que así lo ha oído decir y que también los prendieron porque azotaban un Cristo, y para azotarlo se encerraban en la cocina de su casa y colgaban el Cristo de una soga, y estando colgado lo azotaban con unos espinos, y que su padre tomaba el Cristo de los pies y su madre de la cabeza y lo pasaban por la lumbre, $[\ldots]$ hacer esto no dejaban entrar a este

\footnotetext{
${ }^{273}$ PULIDO SERRANO, Juan Ignacio. Injúrias a Cristo: religión, política y antijudaísmo en el siglo XVII, 2002, pp. 110-111.

${ }^{274}$ Ao lado do primeiro depoimento de Andesillo a Inquisição Portocarrero, descreve "este muchato es de poca razón y capacidade, como tontillo". AHN Inq. Leg. 140 Caixa 2 Exp. 4h, fol 30 (7-9-1630)

${ }^{275}$ AHN Inq. Leg. 140.Caixa 2. Proceso contra Miguel Rodriguez: Caderno das Declarações de Andresillo contra Miguel Rodríguez e Isabel Núñez..

${ }^{276}$ CARRASCO VASQUEZ, Jesus Antonio. La minoria judeoconversa en la época del Conde Duque de Olivares, auge y ocaso de Juan Núñez Saraiva (1585-1639), 2004, p. 346; PULIDO SERRANO, Juan Ignacio. Injúrias a Cristo: religión, política y antijudaísmo en el siglo XVII, 2002, pp. 132-137.

${ }^{277}$ AHN Inq. Leg. 140.Caixa 2. Proceso contra Miguel Rodriguez, fols 25-26.
} 
en la cocina y el se ponia por un agujero que esta en la puerta de la dicha cocina y por alli lo veia todo 278

Apesar de Portocarrero enviar o relato de sua investigação ao Conselho de Suprema Inquisição, para o Inquisidor Geral Antonio Zapata ele anotou nas margens da declaração: "este muchacho es de poca razon y capacidade, como tontillo"279, denotando a pouca credibilidade que ele dera ao depoimento. No entanto, o Conselho da Inquisição decidiu que o Inquisidor deveria recolher novo depoimento do garoto, mas na casa onde tais desacatos teriam acontecido ${ }^{280}$.

Então em 8 de setembro de 1630 Portocarrero, junto a Andresillo, visita a casa, na qual até desenha uma planta ${ }^{281}$ com a intenção de compreender melhor o local do sacrilégio. Mas os conselheiros não ficaram satisfeitos com o novo interrogatório e resolveram enviar o conselheiro Pedro Pacheco para nova visita à casa da calle de las Infantas, o que ocorreu em 16 de setembro. Pacheco teria sido duro com o pequeno, que reafirmou as declarações anteriores e acrescentou o nome de outros participantes do ritual iconoclasta contra o crucifixo ${ }^{282}$.

Um ano mais tarde, com os acusados ainda nos cárceres toledanos, os inquisidores solicitaram ao comissário do Santo Ofício Juan de la Peña que examinasse todos os testemunhos do Caso da calle de las Infantas. Ele assim o fez, e em junho resolver interrogar novamente Andrés. O comissário leu ao menino sua primeira declaração, que respondeu que tudo que dissera era verdade e acrescentou a prodigiosa novidade, que a imagem de Cristo teria falado:

Los dicho sus padres le [imagen de Cristo] ponían unos alfileres en las dichas espinas y cuando le azotaban decía el Cristo que por qué le azotaban y que respondían sus padres que aunque le pesase y amargase le habían de azotar ${ }^{283}$

Podemos destacar que as declarações do pequeno Andresillo foram bastante incongruentes, e como os inquisidores já haviam percebido que o menino seria tontillo, decidiram investigar sua capacidade mental com quatro conhecidos, que atestaram que ele era um menino cujas capacidades mentais seriam inferiores às demais crianças de

\footnotetext{
${ }^{278}$ AHN Inq. Leg. 140.Caixa 2. Proceso contra Miguel Rodriguez, fol 27r-27v.

${ }^{279}$ AHN Inq. Leg. 140.Caixa 2. Proceso contra Miguel Rodriguez, fol 28r.

${ }^{280}$ AHN Inq. Leg. 140.Caixa 2. Proceso contra Miguel Rodriguez, fol 29r-29v.

${ }^{281}$ AHN Inq. Leg. 140.Caixa 2. Proceso contra Miguel Rodriguez, fol 32r.

${ }^{282}$ AHN Inq. Leg. 140.Caixa 2. Proceso contra Miguel Rodriguez, fol 36r-39r.

${ }^{283}$ AHN Inq. Leg. 140.Caixa 2. Proceso contra Miguel Rodriguez, fol 43r-44r.
} 
sua idade ${ }^{284}$. Isso, no entanto, não mudou em nada a decisão do Tribunal da Santa Inquisição Espanhola de relaxar os réus à justiça secular.

Desta forma, a partir do depoimento de um muchacho de poca razón, junto a outros depoimentos dos acusados sob tortura, tais notícias foram capazes de transformar a Madri do século XVII em uma nova Jerusalém, onde um crucifixo teria milagrosamente falado e sangrado ${ }^{285}$, consagrando o chão da casa que mais tarde se tornou o Convento dos Capuchinhos da Paciência de Madri.

\footnotetext{
${ }^{284}$ PULIDO SERRANO, Juan Ignacio. Injúrias a Cristo: religión, política y antijudaísmo en el siglo XVII, 2002, p. 137.

${ }^{285}$ Como já dissemos, no depoimento de Andresillo não encontramos referencia ao jorro de sangue, no entanto, encontramos uma declaração de Miguel Rodriguez de que o crucifixo teria sangrado: "el santo Cristo derramo unas gotas de sangre mui vivas las que salieron de las heridas". AHN Inq. Leg. 140.Caixa 2. Proceso contra Miguel Rodriguez, fol 159r.
} 


\section{As pinturas da Capela da Paciência: os hereges ante o crucifixo milagroso}

Até agora, em nossa dissertação apresentamos as funcionalidades das imagens religiosas na Península Ibérica bem como a conjuntura em que as pinturas, objetos de nossa investigação, foram encomendadas. Neste capítulo, iremos nos dedicar à análise destas imagens, descrevendo os elementos formais que as compõem, como também discutir a figuração do herege e do poder milagroso do crucifixo.

\subsection{Descrição dos elementos formais que compõem as pinturas}

Como apontamos na Introdução, a temática das quatro pinturas é a mesma, um ataque iconoclasta ao crucifixo, referente ao Caso do Cristo da Paciência, mas cada pintor a seu modo compôs os diferentes momentos da injuria e também do milagre do Cristo falar e sangrar.

A primeira que estudaremos é o óleo sobre tela conhecido como Ultrajes ao crucifixo ou Cristo das injúrias (Figura 14), 210 × $231 \mathrm{~cm}$, executado por Francisco Camilo entre 1647-1651 hoje pertence à Biblioteca-Museu Víctor Balaguer, em Villanueva y Geltrú. 


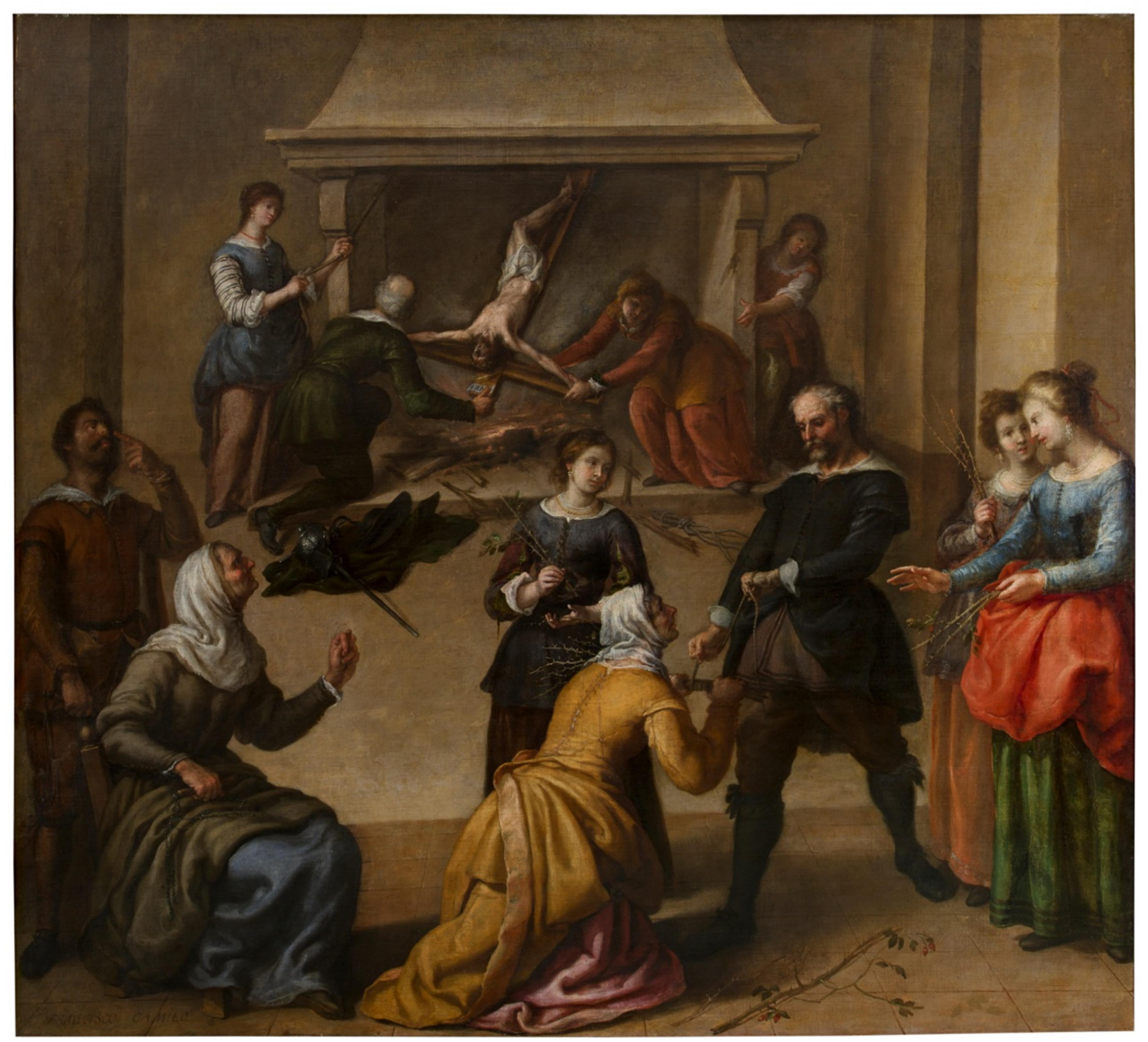

Figura 14 - Ultrajes al crucifijo o Cristo de las injurias, 1647-1651, óleo sobre tela, $210 \mathrm{~cm} \times 231 \mathrm{~cm}$, Francisco Camilo, Museu do Prado, depositado na Biblioteca-Museu Víctor Balaguer em Villanueva y Geltrú. 
Nela, Francisco Camilo retrata o momento em que o crucifixo fora posto sobre o fogo. Apesar de atualmente não estar exposta ao público, pudemos observá-la e constatamos seu ótimo estado de conservação, o que facilitou nosso trabalho. A cena foi configurada em um ambiente interno, um espaço com uma lareira ao centro e ao fundo, e uma passagem à direita do espectador. Mais à frente percebemos uma divisão no ambiente, demarcada pela mudança do desenho do chão e de uma abertura. Suas paredes são de tons ocres, e próximo à lareira o chão é liso, e à frente, Francisco Camilo optou por figurar azulejos mais escuros.

Dentro da lareira acesa há um crucifixo de ponta-cabeça sustentado por três pessoas. A imagem de Cristo na cruz é semelhante às esculturas em madeira que adornavam muitos altares e casas cristãs do período estudado, a efígie de Cristo colorida está pregada à cruz de cor marrom, simulando madeira, e junto à coroa de espinhos e em sua mão direita vemos manchas vermelhas. Sobre sua cabeça, que está inclinada para sua direita vemos uma auréola dourada, e acima, na cruz lemos as insígnias INRI.

Segurando a parte direita do crucifixo, vemos uma mulher inclinada, com vestes em tons vermelhos. Apesar da sombra escura sobre sua face, vemos sua feição delicada, nariz e boca pequena, e seu olhar desvia do crucifixo. O outro personagem que sustenta o crucifixo é um homem calvo e com cabelos grisalhos, que está abaixado e apoiado sobre seu joelho direito, segurando a parte superior e esquerda do crucifixo. Ele está de costas para quem aprecia o quadro, mas notamos sua cabeça levemente virada para a esquerda, sugerindo olhar para a mulher que segura a corda, e não para o crucifixo. Suas vestes são verdes em tons escuros, e no chão ao seu lado vemos outra vestimenta e uma espada prateada, cuja lança está em sentido oposto à imagem de Cristo. Em pé e segurando com as duas mãos uma corda na diagonal, vemos uma jovem, de feições também delicadas, pele clara, nariz e boca pequena e olhos castanhos. Com os cabelos castanhos presos, usa um brinco com pingente e um colar de contas vermelhas. Suas vestes são uma saia amarelada e blusa branca sobreposta por um vestido azul. Ainda próximo à lareira, à direita do espectador, vemos outra jovem observando a cena, de meio corpo quase escondida sobre a sombra. Seus cabelos são ruivos e suas vestes são em tons amarelos sobre roupas brancas, e sua mão esquerda está apoiada na lareira. 
À frente e à esquerda do espectador dois personagens nos chamam a atenção: em pé um homem jovem, de bigode com cabelos escuros olha para o alto e com o dedo indicador esquerdo aponta para sua face. Suas vestes são em tons de ocre, e com sua mão esquerda segura um chicote de várias tiras. Logo à sua frente Camilo figurou uma idosa sentada, de vestes verdes sobre uma saia azul e com sua cabeça coberta por um lenço branco. Com sua mão direita ela segura um açoite ou azorrague romano, e com a esquerda ela faz uma figa. Sua expressão é envelhecida e seu olhar é fixo, suas rugas são acentuadas, tem poucos cabelos, que estão soltos e, como suas sobrancelhas, são grisalhos.

Ao centro, à frente, vemos outra senhora, ajoelhada, de vestes amarelas sobre uma saia avermelhada, também tem os cabelos cobertos com um lenço branco, sua expressão é envelhecida e seus cabelos são grisalhos e seu olhar esta voltado para o homem que está em pé a sua frente. Com suas duas mãos segura um objeto envolto por uma corda que o homem à sua frente estica com suas duas mãos. Ele também não é jovem, é calvo com cabelos e barbas brancos e face enrugada. Veste um paletó escuro sobre uma camisa branca e suas calças e botas são marrons. Atrás da senhora em pé, Camilo figurou uma jovem de cabelos castanhos e de feições delicadas, adornadas por brincos e colares de contas. Suas vestes são azul e marrom sobre uma camisa branca, e com as duas mãos segura sois galhos de espinhos.

À direita do observador, vemos mais duas jovens, que parecem interagir. A que está à frente, representada de perfil, é loira e suas feições suaves são adornadas por brincos e colares de perolas. Usa uma blusa azul e uma saia vermelha sobre uma verde, com sua mão direita segura dois ramos de espinhos com rosas em botão. A outra jovem está atrás, seus cabelos são mais escuros e também possui feição doce e usa adornos de contas. Suas vestes são em ocre sobre uma saia alaranjada e com sua mão esquerda segura três ramos de espinhos.

A segunda é a pintura de Francisco Rizi ficou conhecida como Profanação de um crucifixo - Família de hereges açoitando um crucifixo (Figura 15) é um óleo sobre tela cujas dimensões são 207 x $230 \mathrm{~cm}$, e fora produzida entre 1647-1651 e hoje pertence ao Museu do Prado. 


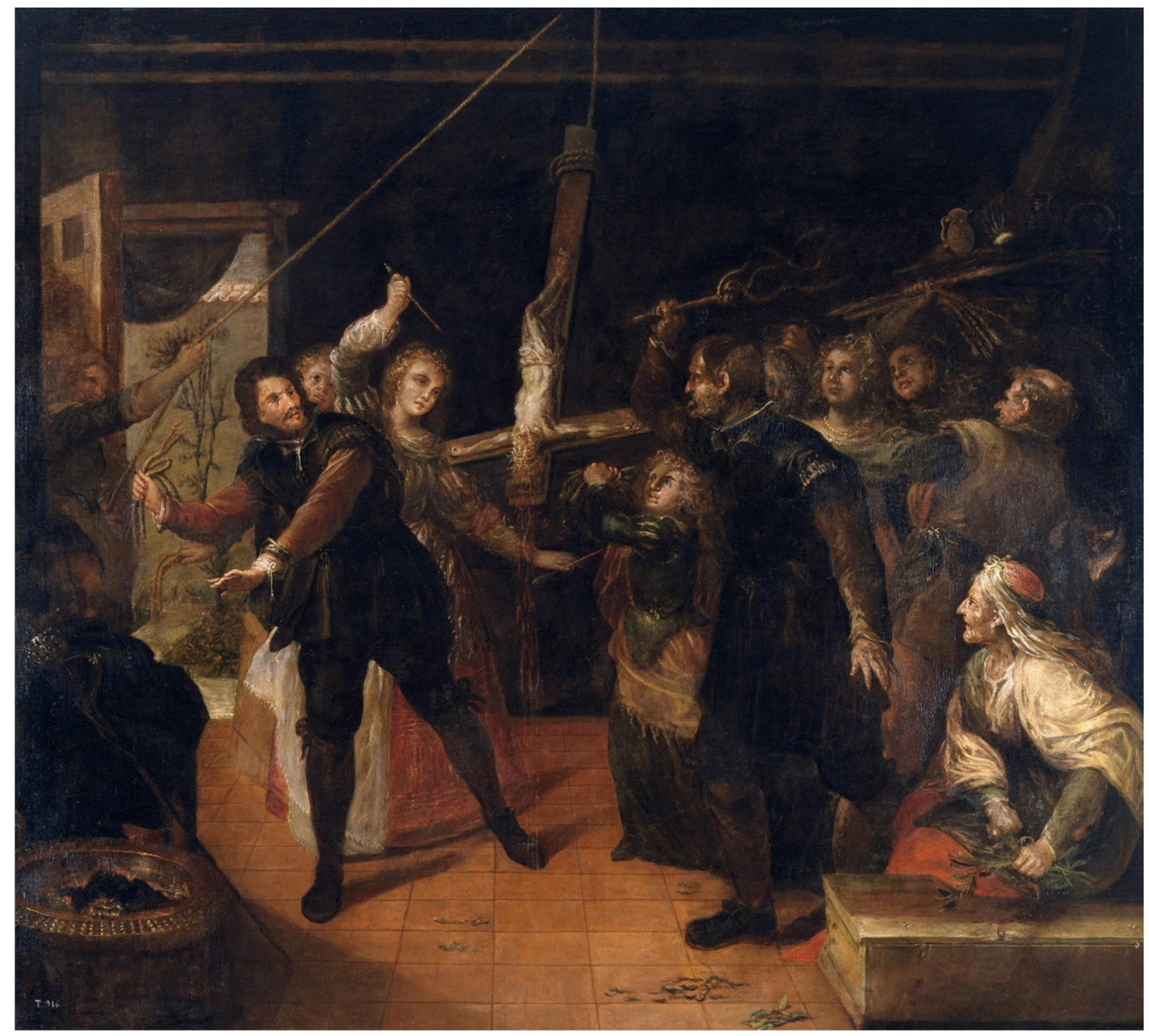

Figura 15 - Profanación de un crucifijo (Familia de herejes azotando un crucifijo), 1647-1651, óleo sobre tela, $207 \mathrm{~cm}$ x 230 cm, Francisco Rizi, Museu do Prado [P03775]. 
Nesta obra Francisco Rizi representa o momento em que o crucifixo teria sangrado. Apesar não estar exposta ao público, tivemos acesso a ela nos depósitos do Museu do Prado, e verificamos o seu ótimo estado de conservação.

Rizi concebeu a cena do milagre em que o crucifixo teria sangrado em um ambiente interno, com uma porta aberta para o exterior ao fundo, do qual podemos ver uma pequena árvore, e um pequeno caminho entre um jardim de flores que termina com uma construção. Da porta, aberta para dentro desce uma tecido escuro que poderia ser uma cortina. No ambiente interno podemos observar alguns móveis como uma prateleira à direita do espectador como potes, um caixote de madeira e um braseiro. É um ambiente escuro e o chão feito de ladrilhos marrons avermelhados, no qual ao centro está o sangue que derrama do crucifixo, além de algumas folhas caídas.

Ao centro da cena está um crucifixo, pendurado de ponta-cabeça por uma corda. O crucifixo desta pintura é um pouco menor que os das demais, mas notamos que a intenção foi figurar Cristo pregado à cruz e coroado, talhado em madeira e depois pintado. E da cabeça de Cristo escorre um líquido vermelho representando o sangue, fruto do milagre. A corda que sustenta o crucifixo vai até o limite da pintura e depois volta em diagonal para à esquerda do espectador e é segurada por uma mulher bem próxima à porta. Seus cabelos são claros e se confundem com a cor da porta, de semblante jovem e olhar em direção da corda, suas roupas são escuras sobrepostas a outras mais claras. À sua frente vemos uma espécie de manto azul escuro que cobre um objeto e nele está apoiado um florete com a lança para baixo.

Entre esta mulher e o crucifixo vemos figuradas três pessoas, mais à frente um homem inclinado, ele possui barba e cabelos castanhos, é jovem e suas vestes são marrom escuro sobre uma camisa mais clara. No seu punho esquerdo notamos uma fita branca amarrada semelhante a um tzitzit e algo que parece parte de tefilin, e em sua mão direita carrega um açoite. Logo atrás deste homem, vemos uma mulher de feições jovens e com um leve sorriso olhando para o crucifixo, com cabelos loiros, usa brincos e vestes ornamentadas sobre uma saia vermelha. Com sua mão esquerda, que está levantada, segura uma pequena lança com ponta tripartida e vermelha apontada para a imagem de Cristo, com sua mão esquerda carrega outro objeto pontiagudo que também tem a ponta vermelha. Entre o homem e a mulher observamos um tecido branco com franjas, que não pudemos definir se fazia parte das vestes da mulher ou do homem. 
Atrás destes dois personagens vemos uma cabeça que não conseguimos identificar o gênero, apenas que é jovem e possui cabelos loiros.

No lado direito da pintura para o observador, vemos figurados os demais personagens que compõem a cena. Mais próximo ao crucifixo, logo abaixo, vemos, olhando para o objeto, uma criança loira que segura com as duas mãos um açoite. Suas vestes são em tons de verde e amarelo. Ao seu lado, Rizi figurou um homem já idoso, calvo, de feições rudes, realçadas pelo nariz grande e o volumoso lábio inferior, olhando para o crucifixo. Ele está com a mão direita levantada segurando um chicote e, com a outra mão, algo parecido com um chapéu. Suas vestes são escuras, mas podemos notar ornamentos na manga e na gola. Ao seu lado vemos outro homem também idoso e calvo, também de feições rudes (destacadas pelo tamanho do nariz), trajando uma roupa mais clara sobre uma camisa verde. Atrás, entre os dois homens, podemos ver o rosto de três jovens. Uma está olhando para baixo e com a mão em seus cabelos, outra de cabelos loiros olha para o crucifixo, e a mais à direita vemos outra que segura um açoite.

À frente foi representada uma idosa, que está sentada sobre um caixote. Suas feições envelhecidas são evidenciadas com seu olhar arregalado e seu nariz protuberante. Seus cabelos são brancos e longos, estão soltos e cobertos apenas por um pequeno turbante alaranjado. Suas vestes são em tons verdes e laranja, cobertos por um lenço branco, e com as duas mãos segura uma porção de ramos com folhas.

A terceira pintura, o Sacrilegio de uns judeus (Figura 16), 171 x $296 \mathrm{~cm}$, também um óleo sobre tela, foi concebida por Francisco Fernandez, e hoje pertence ao Museu do Prado. 


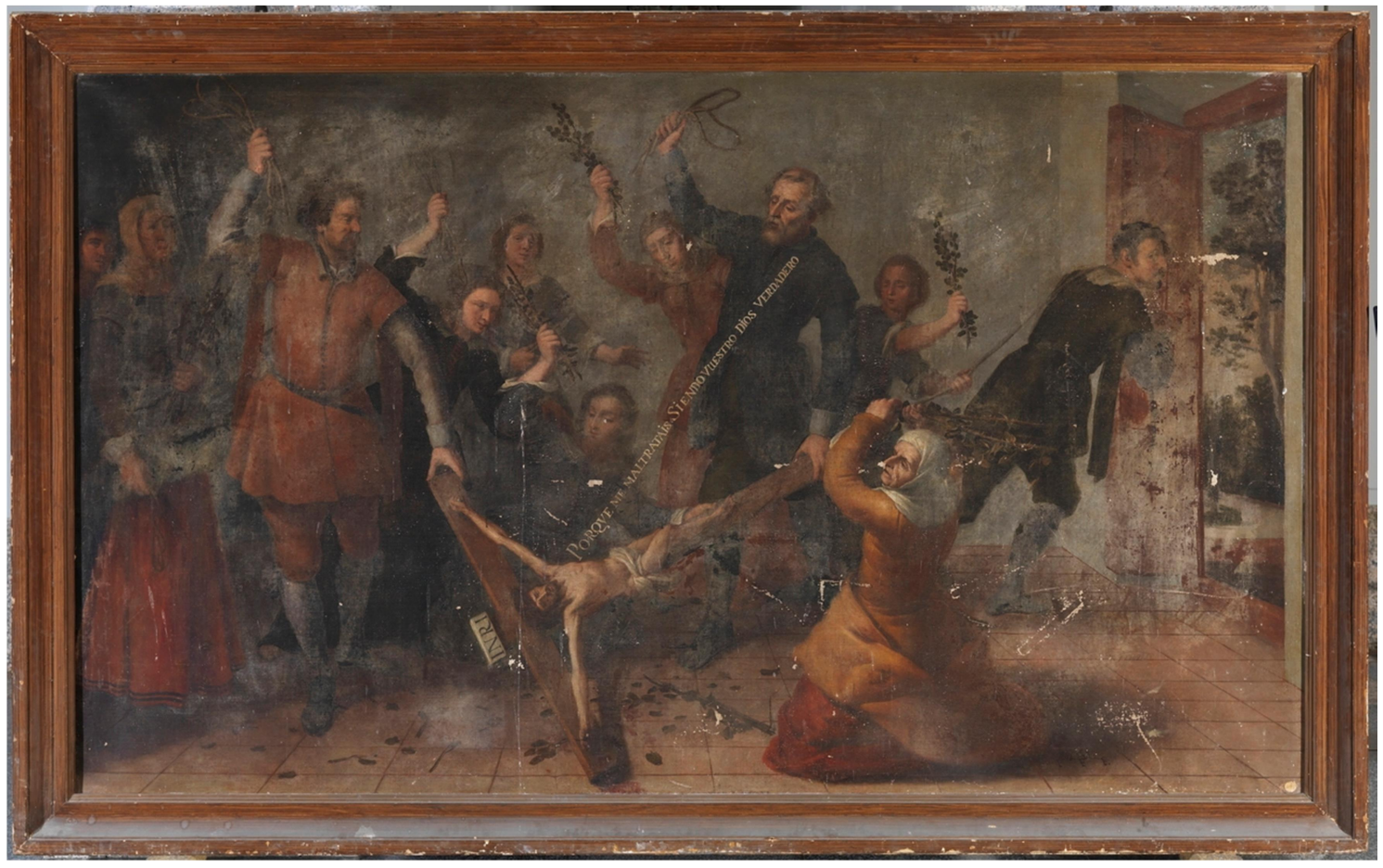

Figura 16 - Sacrilegio de unos judios: judios arrastando y azotan el crucifij, 16471651, óleo sobre tela, 171 x 296 cm, Francisco Fernadez, Museu do Prado [P03873]. 
Esta pintura narra o momento em que o crucifixo falou a seus algozes. Apesar de estar nos depósitos do Museu do Prado, não pudemos observá-la. Tivemos acesso apenas a uma imagem digitalizada em alta resolução, a partir da qual constatamos a necessidade de sua restauração. Tal restrição à inspeção da obra original e os danos verificados na imagem dificultaram um pouco nosso trabalho, pois não conseguimos identificar bem alguns elementos e cores da pintura.

A cena foi concebida em um ambiente interno no qual está reunido um grupo de onze pessoas a flagelar a imagem de Cristo. À direita do observador, vemos uma porta aberta para o exterior, onde há uma árvore e alguns arbustos. As paredes são acinzentadas e o assoalho, no qual vemos folhas e gravetos espalhados, em ladrilhos marrons.

Ao centro está uma imagem de Cristo crucificado, em diagonal e de pontacabeça, rodeada pelo grupo. Fernandez figurou uma efígie colorida de Cristo na cruz, acreditamos que sua intenção seria representar um crucifixo com Cristo talhado em madeira e pintado. Acima do crucifixo, próximo a sua face, vemos em branco e em caixa-alta as seguintes palavras "PORQVE ME MALTRATAIS SIENDO VUESTRO DIOS VERDADERO”.

À frente da cena, próximo à parte inferior do crucifixo, Francisco Fernandez figurou uma idosa de joelhos, com vestes amarelas sobrepostas a uma saia avermelhada. Sua cabeça está coberta por um lenço branco, e suas expressões rudes são definidas pela face enrugada. Suas mãos estão voltadas para o alto e carregam dois ramos com folhas e espinhos. À direita do espectador, vemos, em pé, voltado para a porta, um homem que segura a corda da qual pende o crucifixo. Este homem possui cabelos e barba castanhos. Também segurando a corda e alguns galhos, logo atrás da idosa, vemos uma criança de feições singelas e vestes escuras. Ao lado direito da criança, em pé, vemos um idoso, também em vestes escuras, de cabelos e barba grisalhos. Com sua mão esquerda, segura a parte inferior do crucifixo, e com a direita levanta para o alto um açoite. Atrás, à direita deste homem, podemos ver uma mulher com os cabelos cobertos por um lenço amarelado e vestes amarelas, sua mão direita está levantada e segura alguns galhos com folhas verdes. 
Ao lado e abaixo desta mulher vemos três jovens. Uma delas usa um vestido azul, está ajoelhada, e com uma das mãos segura o crucifixo, enquanto com a outra levanta alguns ramos. Atrás dela veem-se as outras duas, uma está de vestes escuras e com galhos nas mãos, e a outra, de vestes azuladas e com os braços abertos.

Segurando a parte esquerda do crucifixo, Fernandez figurou um homem em pé, de cabelos e barbas castanhos; suas vestes são em tons de ocre, sua mão direita está levantada e segurando um chicote. À esquerda do espectador, e atrás deste homem, podemos ver uma mulher com a cabeça coberta por um lenço, e em sua mão um punhado de gravetos. Atrás desta mulher, podemos ver a face de um homem imberbe, uma jovem talvez.

Já o desaparecido Cristo no braseiro (Figura 17), a quarta pintura, foi concebida pelo mestre coquence Andrés de Vargas e foi destruída em um incêndio na cidade galega de Porriño. 


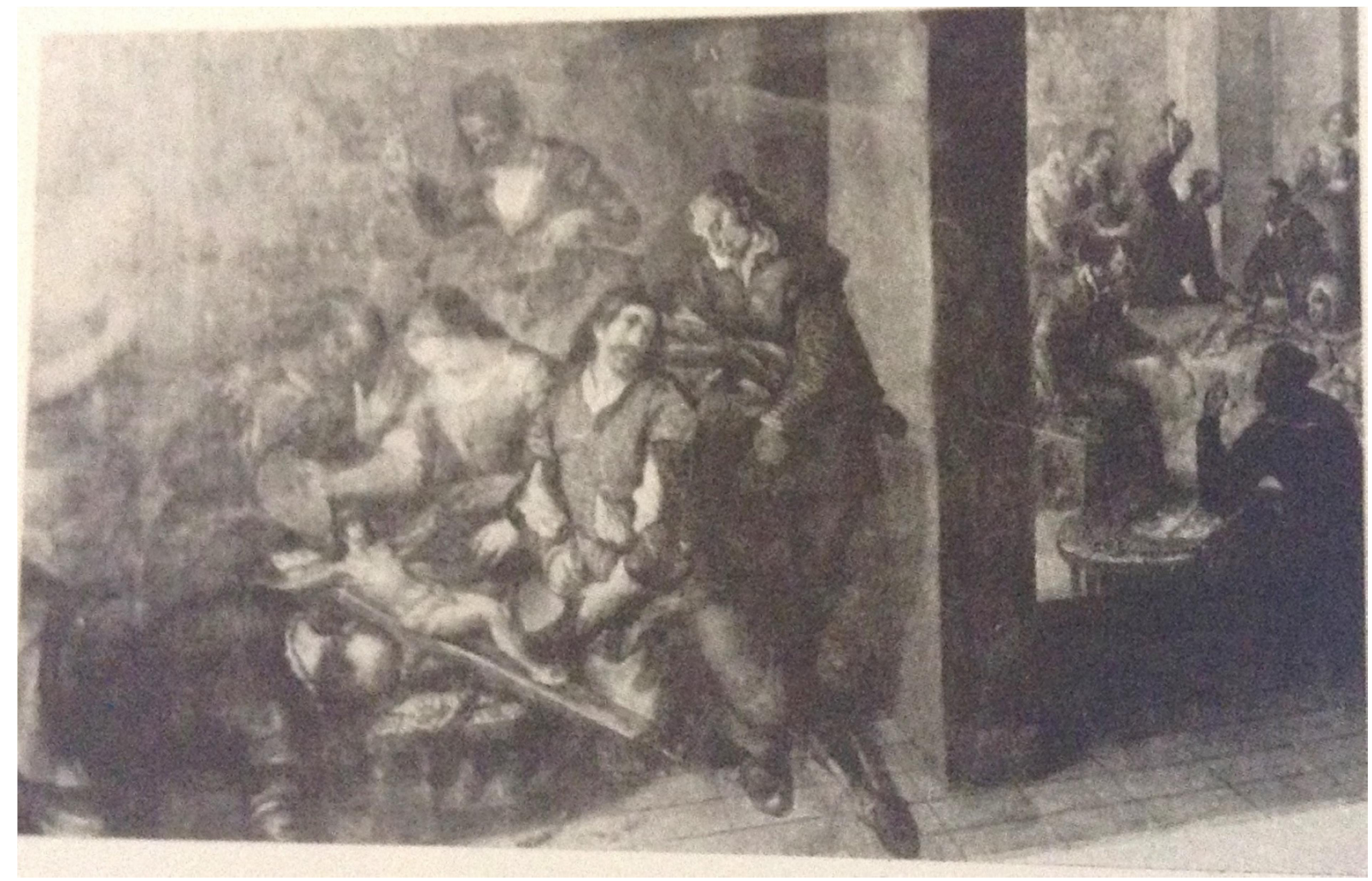

Figura 17 - Martirio del brasero del Cristo de la Paciencia, 1647-1651, óleo sobre tela, $171 \mathrm{com}$ x $296 \mathrm{~cm}$, Andrés de Vargas. Fonte: MUSEO DEL PRADO. Inventario general de pinturas II. El Museo de la Trinidad. Madrid: Espasa Calpe, 1991. 
Esta é a única reprodução que restou da pintura de Andrés de Vargas. Observamos que o pintor compôs dois momentos do suposto ataque. No primeiro, à esquerda do espectador, ocupando a maior parte da tela podemos observar que a imagem de Cristo está posicionada sobre um braseiro, só conseguimos identificar sete personagens, quatro homens e três mulheres. Já na cena menor, num plano mais ao fundo à esquerda do observador, o crucifixo está ao centro de nove personagens, e um deles, um homem calvo, que com sua mão direita segura o crucifixo e com a esquerda segura ao alto uma espécie de martelo. Aqui não conseguimos ver se o crucifixo ainda está inteiro ou despedaçado. Nesta mesma cena, podemos ver também uma personagem feminina que parece fazer uma figa, da mesma forma que a idosa do quadro de Francisco Camilo.

Quando olhamos para o conjunto das pinturas, a despeito do tema em comum, percebemos que não houve preocupação com a uniformidade visual. Parece que a intenção do comitente, ao contratar artistas diferentes, não seria a de que estas pinturas compusessem uma narrativa visual com coesão formal e estilística, como podemos observar na maioria dos ciclos de pinturas de narrativas religiosas, como por exemplo, as obras que abordaremos nas páginas seguintes, que figuram as cenas da vida de Santo Estêvão, de Juan de Juanes (Figura 32), ou a série de pinturas de Vicente Carducho, que narram a históra da Ordem dos Cartuxos, para o convento de Santa Maria del Paular ${ }^{286}$.

Todas as pinturas figuram o ataque iconoclasta ao crucifixo, representando momentos distintos do suposto caso do Cristo da Paciência, mas percebemos que cada artista elaborou sua pintura à sua maneira. Por exemplo, vemos que, em cada imagem, as representações do ambiente interno, o cômodo em que o crime ritual teria acontecido, são bem distintas. Apesar de em todas elas o chão ser de ladrilho, na pintura de Rizi (Figura 15) a porta está à esquerda do espectador, e, na de Fernandez (Figura 16) à direita, já o ambiente de Camilo (Figura 14) não possui portas, mas sim elementos arquitetônicos que sugerem passagens para outros cômodos da casa, como a abertura figurada na pintura de Vargas (Figura 17). O mesmo pode ser notado com outros elementos, como a lareira que aparece somente na pintura de Camilo (Figura 14), que toma a forma de um braseiro nas de Rizi (Figura 15) e Vargas (Figura 17), enquanto na pintura de Fernandez (Figura 16) o fogo nem é representado. Outro componente que

\footnotetext{
${ }^{286}$ MUSEU DO PRADO. Coleccion. www.museodelprado.es/coleccion/obra-de-arte/el-martirio-de-los-
} cartujos-de-roermond/0e95d9a3-ba1b-4146-800e-dd54feda1 fac. Acesso em 22/01/2016. 
também recebeu tratamento distinto foi o crucifixo, que em cada pintura foi figurando em um tamanho diverso, e o mesmo podemos dizer das características físicas dos hereges. Ainda não devemos nos esquecer da obra de Andrés de Vargas (Figura 17), que representa pictoricamente dois momentos do suposto sacrilégio.

Cabe ressaltar que esta característica deste corpus - a diversidade dos artistasacaba por enfatizar a singularidade estilística de cada um deles. Pois, provavelmente seguindo as intruções do comitente, que teria escolhido o tema, e também qual momento do sacrilégio cada um iria pintar, tal decisão acabou por dar espaço - dentro do limite das possibilidades daquele momento histórico - para diferentes modos de composição do milagre, da agressão e da fisionomia dos hereges. E, por este ponto de vista, podemos inferir que tal opção, de certa forma, poderia ressaltar a gravidade do ato e sua condenação, pois seria como se houvesse várias "mãos" criticando o ataque iconoclasta e participando do projeto expiatório.

\subsection{A figuração dos hereges}

Para Jérôme Baschet, até o século XI teria ocorrido uma convivência sem grandes problemas entre cristãos e judeus, sendo que estes últimos formavam uma minoria aceita e até chegaram a ocupar cargos nas cortes reais (médicos ou administradores fiscais). ${ }^{287}$ Mas, com a afirmação crescente do cristianismo e a configuração social da cristandade, sob a égide de poder da Igreja, passou a ocorrer uma maior perseguição, por vezes violenta, contra os hebreus. Desta feita, foi se configurando ao longo do período medieval, no seio da cristandade, um estereótipo do judeu inimigo da fé cristã ${ }^{288}$.

\footnotetext{
287 "Dotados de uma fraca presença total [...], mas bem implantados em certas cidades ondem podem representar até um quarto ou um teço da população, as comunidades judaicas se beneficiam de uma proteção real (em contrapartida a uma sujeição direta em relação ao rei), imperial e pontifícia (pois a Igreja julga útil a presença dos judeus enquanto povo que testemunhou a crucificação de Cristo). Para os cristãos, os judeus são, então, 'duplo, ao mesmo tempo respeitados e detestados, herdeiros do Antigo Testamento, mas infiéis a essa herança"”. BASCHET, Jérôme. A civilização feudal: do ano mil à colonização da América, 2006, p. 237.

${ }^{288}$ CANTERA MONTENEGRO, Henrique. La imagen del judío en la España Medieval. Espacio, tiempo y forma. Serie III, Historia medieval. Madrid, 1998, n¹1, pp. 11-38; ESPI FORCÉN, Carlos. Érase un Hombre: a una nariz pegado. La fisiognomía del judío en la baja Edad Media. In: CONGRESO
} 
Este imaginário antijudaico alimentou-se de inúmeras lendas e de narrativas como a dos judeus serem responsáveis pela morte de Cristo ${ }^{289}$. Segundo Paulino Rodriguez Barral, esta ganhou mais popularidade com as Cruzadas e com a progressiva valorização do culto ao Cristo Sofredor ${ }^{290}$. O crime ritual igualmente tomou conta do imaginário cristão, quando começaram os rumores de que os judeus se reuniam em rituais para renovar a Paixão de Cristo por meio do assassinato de crianças cristãs ${ }^{291}$, culminado no caso do Santo Niño de la Guardia, ${ }^{292}$, cuja lenda tornou-se muito conhecida na Espanha após o século XV. Ainda podemos apontar as inúmeras alusões antijudaicas disseminadas entre cristãos do final da Idade Média e do início da modernidade: eles seriam profanadores de hóstias ${ }^{293}$; planejariam exterminar o cristianismo, através de seus médicos envenenariam seus pacientes cristãos ${ }^{294}$; e teriam colaborado com a invasão islâmica na Espanha ${ }^{295}$. O fator econômico também foi determinante, e os judeus eram sempre acusados de usurários e excessivamente preocupados com o dinheiro ${ }^{296}$.

Da mesma forma que estes mitos propagaram o topos do judeu iconoclasta fora configurado e retomado ao longo do período medieval, através das várias legendas

INTERNACIONAL IMAGEM Y APARENCIA. Murcia: 2008. Atas... Murcia: Universidad de Murcia, Servicio de Publicaciones, 2009.

${ }^{289}$ ESPINA, Alonso de. Fortaleza da Fé, Livro III. Séptima consideración. Primer punto: La crueldad de los judíos sobre su próprio Mesías. Posição 4013-6683.

290 RODRIGUEZ BARRAL, Paulino. La imagen del judío en la España medieval: el conflicto entre cristianismo y judaísmo en las artes visuales góticas, 2008, p 96.

${ }^{291}$ Juan Molina Figueras aponta que alguns autores medievais chegaram a afirmar que os judeus tinham conhecimento da divindade de Jesus, e agiram com maldade absoluta, e num processo de transferência a culpa pela sua morte se estendeu a todo o povo hebreu até o fim dos tempos, fortalecendo assim o estigma do deicídio. MOLINA FIGUERAS, Joan. La Imagen y su contexto. Perfiles de la Iconografía antijudaíca en la España Medieval. In: Els jueus a la Girona medieval (XII ciclo de conferencias Girona a l'Abast). Girona: Bell-1loc, 2007, p. 53; ver também: RODRIGUEZ BARRAL, Paulino. La acusación de crimen ritual: una aproximación a su iconografía a partir del caso del "Santo Niño de La Guardia". El Olivo, Madrid, 2006, 63, p. 68.

${ }^{292}$ Este caso teria ocorrido em 1490, e os acusados foram condenados pela Inquisição, que contou com a atuação direta do Inquisidor Geral Frei Tomas de Torquemada. Assim como o Caso do Cristo da Paciencia, a lenda do Santo niño de la Guardia foi amplamente difundida visualmente. RODRIGUEZ BARRAL, Paulino. La acusación de crimen ritual: una aproximación a su iconografía a partir del caso del "Santo Niño de La Guardia". 2006, p. 68; CANTERA MONTENEGRO, Henrique. La imagen del judío en la España Medieval, Madrid, 1998, n 11, pp. 11-38.

${ }^{293}$ RODRIGUEZ BARRAL, Paulino. La imagen del judío en la España medieval: el conflicto entre cristianismo y judaísmo en las artes visuales góticas, 2008.

${ }^{294}$ CANTARE MONTENEGRO, Henriquez. El miedo al judío en la España de la Edad Media. In: Estudio de Historia de España ${ }^{\circ} 13$, Buenos Aires: Universidad Catolica Argentina, 2013, pp 162-171. ${ }^{295}$ Sobre o mito da colaboração com na invasão islâmica ver BRAVO LOPÉZ, Fernando. «La traición de los judíos» La pervivencia de un mito antijudío medieval en la historiografía española. Miscelanea de Estudios Arabes y Hebraicos. Granada, 2014, vol 63, pp. 27-56; CANTARE MONTENEGRO, Henriquez. El miedo al judío en la España de la Edad Media, 2013.

${ }^{296}$ CANTARE MONTENEGRO, Henriquez. El miedo al judío en la España de la Edad Media, 2013, pp 31-35. 
sobre os milagres de crucifixos sangrantes. A principal delas é a da Passio Imaginis ou o milagre do Crucifixo de Beirute, cuja narrativa já apontamos aqui ${ }^{297}$, e que muito se assemelha ao caso do Cristo da Paciência.

\section{A fisionomia dos marranos}

Desta maneira, no seio das comunidades cristãs e sob a influência destas várias lendas de caráter antijudaico, ocorreu a formação de uma imagem pictórica depreciativa daqueles que professavam a fé mosaica (e mais tarde daqueles que se converteram ao cristianismo). Estas representações ocorreram muitas vezes por meio de fisionomias deformadas e também por certas características das indumentárias, como o tipo de roupa e as cores, dentre outros elementos ${ }^{298}$. Para o historiador da arte Carlos Espí Jocén, o atributo fisionômico mais representativo dos judeus, na baixa Idade Média, era o nariz de tamanho desproporcional ${ }^{299}$.

Segundo Espí Jocén, o uso das fisionomias deformadas nas representações pictóricas baseou-se, em parte, na teoria da fisionomia, segundo a qual se observava o caráter de um indivíduo por meio de seu tipo físico e traços faciais, teoria vinda desde antiguidade e que perdurou por séculos. Na Espanha do Século de Ouro, tratadistas como de Vicente Carducho, Francisco Pacheco e Jusepe Martinez, através desta teoria instruíam seus leitores/artistas como deveriam compor, de acordo com o decoro ${ }^{300}$, os traços fisionômicos de um determinado personagem ${ }^{301}$.

Na concepção do pintor e tratadista Vicente Carducho, na obra Dialogos de la Pintura, finalizada em 1633, um pintor prudente deveria figurar a feição de pessoas

\footnotetext{
${ }^{297}$ Ver capitulo 2, pp. 42-43.

${ }^{298}$ Ver: MOLINA FIGUERAS, Joan. La Imagen y su contexto. Perfiles de la Iconografía antijudaíca en la España Medieval, 2007.

${ }^{299}$ ESPI FORCÉN, Carlos. Érase un Hombre: a una nariz pegado. La físiognomía del judío en la baja Edad Media, 2008.

${ }^{300}$ Ver: PACHECO, Francisco. Arte de la pintura, su antigüedad y su grandeza. Sevilla: Simón Fajardo, 1649. Tomo I. Libro II. Cap. I, II, III e IV.

${ }^{301}$ ALBERO MUÑOZ, Maria de Mar. La investigación sobre Fisiognomía y expresión de las pasiones: objetivos y metodología. Panta Rei: revista de ciencia y didáctica de la historia. Murcia, 2008, pp. 233-248; DELGADO MARTINEZ, Natalia. Fisiognomía y expresión en la literatura artística española de los siglos XVII y XVIII. Anuario del Departamento de Historia y Teoría del Arte. Murcia, 2002, v. XIV, pp. 205-229.
} 
consideradas infames de maneira que a aparência concebida pudesse revelar sua natureza execrável:

no tendrá el mismo rostro ni las mismas facciones, colores y miembros, regularmente hablando, el que fue santo y piedoso, que el que fué inícuo, cruel, y tirano; no la doncella vergonzosa, como la meretriz deshonesta: pues en el Derecho en un delito que se imputa á dos, presume más culpa en el de rostro y talle feo, que en el que le tiene más hermoso y perfecto. Y asentado esto, ¿quién no conocerá, que el Pintor que no tuviere entera noticia destas cosas está sujeto a hacer estos errores tan importantes para el fin principal a que mira esta facultad, pues ha de mover y representar con fidelidad la intencion del artífice. Por tanto el que fuere mero imitador de lo natural exterior, desnudo de los preceptos y conocimientos, ¿Cómo ha de acertar, puesto que no conoce esas diferencias y concordancias?... ${ }^{302}$

Como podemos observar, apesar dos preceitos de Carducho, nas imagens que analisamos os pintores não fizeram uso da metáfora visual da infâmia pela deformação física dos hereges.

${ }^{302}$ CARDUCHO, Vicente. Dialogos de la Pintura: su defensa, origen, esse[n]cia, definicion, modos y diferencias. Madrid: Francisco Martínez, 1633, pp.120-121. 


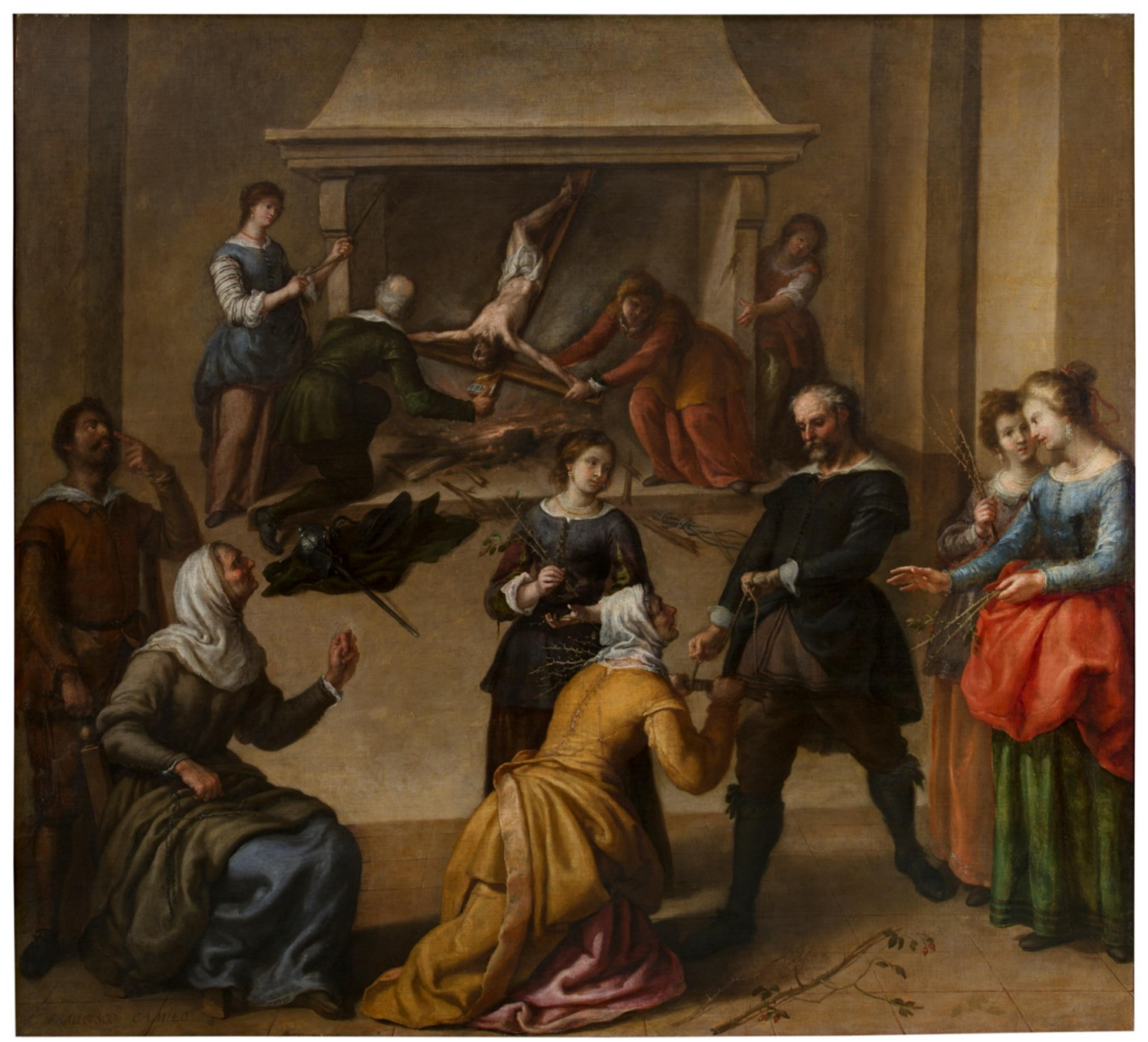

Figura 18 - Ultrajes al crucifijo o Cristo de las injurias, 1647-1651, óleo sobre tela, $210 \mathrm{~cm}$ x $231 \mathrm{~cm}$, Francisco Camilo, Museu do Prado, depositado na Biblioteca-Museu Víctor Balaguer em Villanueva y Geltrú. 
Na pintura Ultrajes al crucifijo o Cristo de las injurias, Francisco Camilo (Figura 18) não figura as feições dos personagens (judaizantes) com as deformações faciais que tipicamente lhes são atribuídas como metáfora de sua natureza infame ${ }^{303}$. Nas fisionomias delineadas pelo artista vemos concebidas as suas diferentes idades com as características que o passar dos anos traz a todas as pessoas, independentemente de suas índoles boas ou más. Apesar do personagem masculino, mais à esquerda do espectador que se destaca dos demais, ser figurado com um tom de pele mais escura que olha para o alto e com o dedo indicador esquerdo aponta para sua face, seus traços não são deformados (Figura 19). O que encontramos, além do evidente agravo, são os elementos como os ramos de espinho, sugerindo a intenção de agressão, além da mão em figa da idosa, considerado um gesto obsceno ${ }^{304}$, deixando claro o desrespeito diante da cruz.

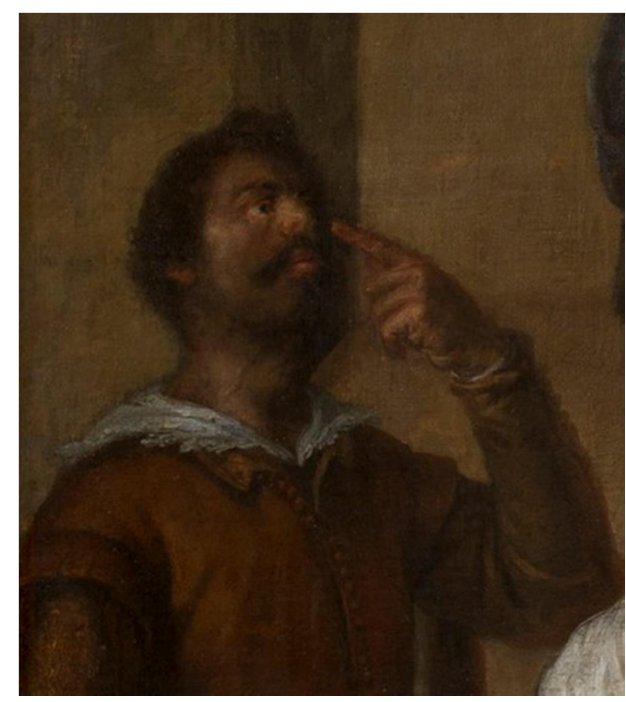

Figura 19 - Detalhe: Ultrajes al crucifijo o Cristo de las injurias (Figura 19)

\footnotetext{
${ }^{303}$ Ver: RODRIGUEZ BARRAL, Paulino. El recurso al judío deicida: un punto de encuentro entre el drama y las artes visuales en la Valencia de la edad media final. Estudios sobre teatro medieval. Valencia: Universidad de Valencia 2008, pp. 157-174; MOLINA FIGUERAS, Joan. Las imágenes del judío en la españa medieval. In: Memoria de Sefarad. Madrid: Sociedad Estatal, 2002, pp. 373-382.

${ }^{304}$ Ver: PAOLINI, Devid. El gesto obsceno ‘dar las higas' en la Celestina. Celestinesca. Valencia, 2000, n 33 , pp. $127-141$.
} 


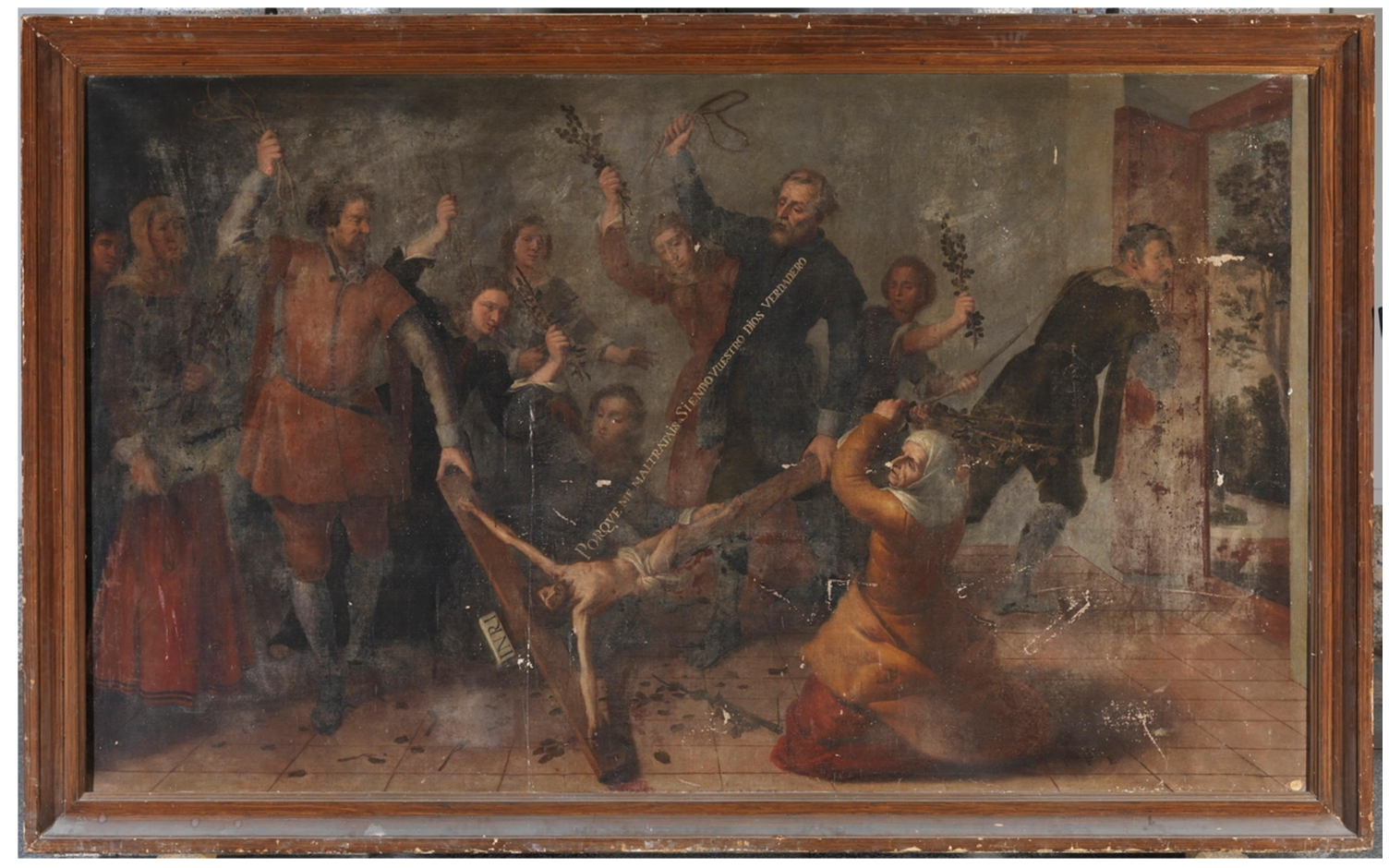

Figura 20 - Sacrilegio de unos judios: judios arrastando y azotan el crucifijo, 16471651, óleo sobre tela, 171 x 296 cm, Francisco Fernadez, Museu do Prado [P03873]. 
Na pintura de Francisco Fernadez, Sacrilegio de unos judios: judios arrastando $y$ azotan el crucifijo, (Figura 20), a despeito do seu estado de conservação e de seus traços serem mais rígidos, o que por si já proporciona aos seus personagens uma fisionomia mais rude (Figura 21), as características físicas delineadas não compõem personagens grotescas. Os traços permitem-nos distinguir as diversas idades e alguns aspectos físicos, como nariz maior, mas não deformado, aparecem como característica individual. Podemos apontar, além do agravo e do milagre, o uso excessivo de tons amarelos como eventual indício de heresia ${ }^{305}$.

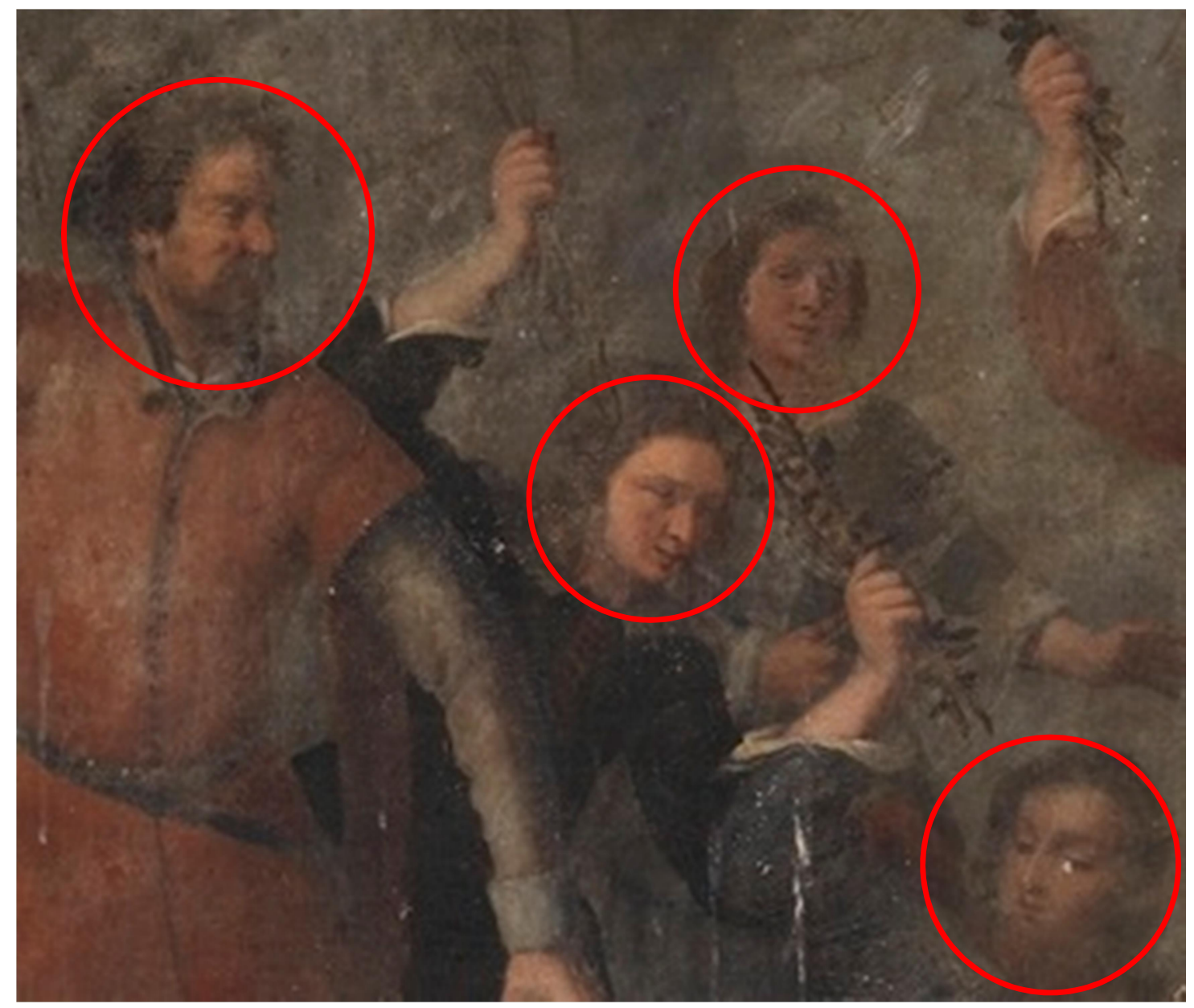

Figura 21 - Detalhe: Sacrilegio de unos judios: judios arrastando y azotan el crucifijo (Figura 20)

\footnotetext{
${ }^{305}$ Ver: PASTOUREAU, Michel. Formes et couleurs dú desordre: le jaune avec le vert. Médiévales, $\mathrm{n}^{\circ} 4$.
} 1983 pp. 62-73. 


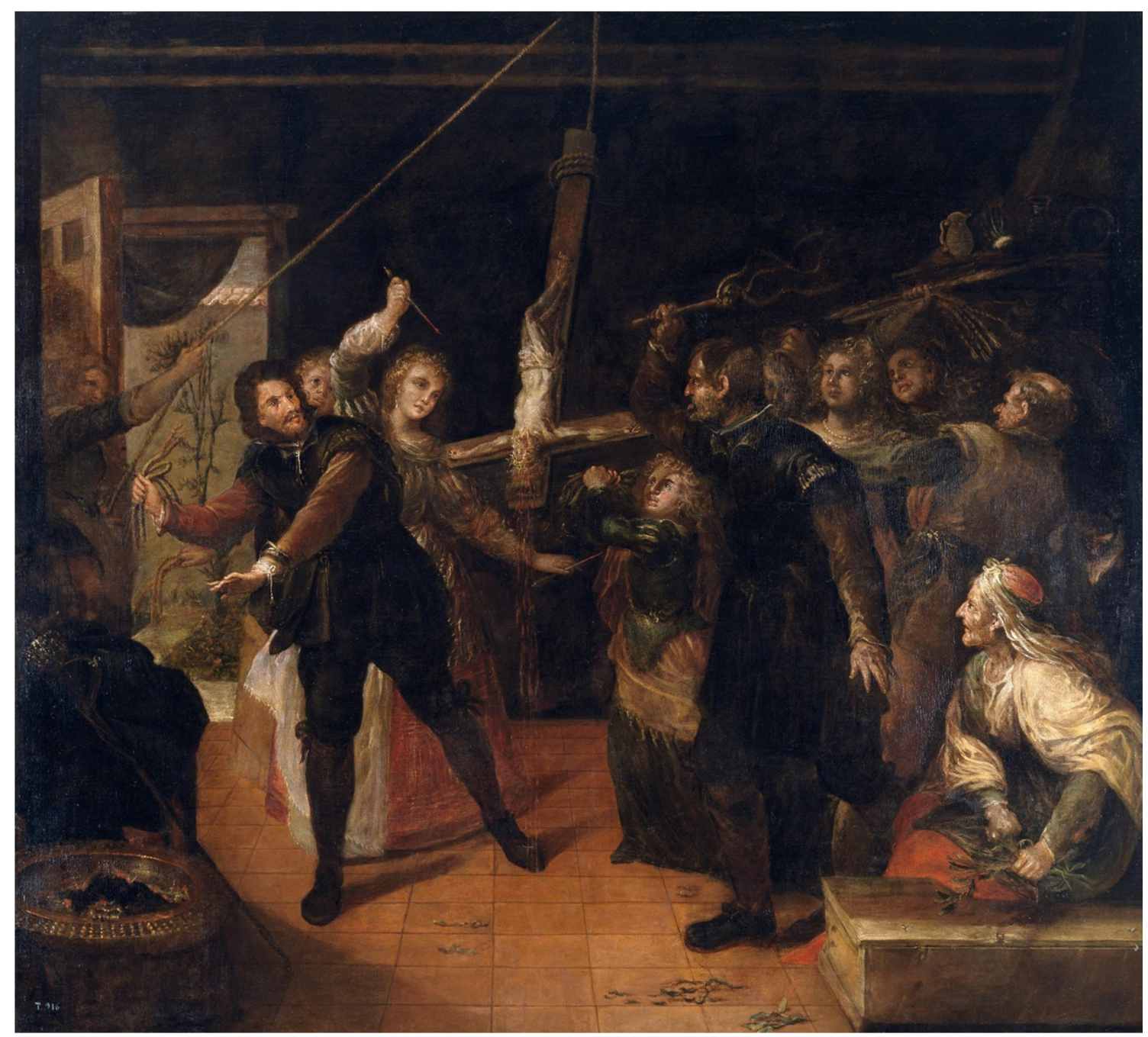

Figura 22 - Profanación de un crucifijo (Familia de herejes azotando un crucifijo), 1647-1651, óleo sobre tela, $207 \mathrm{~cm}$ x 230 cm, Francisco Rizi, Museu do Prado [P03775]. 
Na pintura elaborada por Francisco Rizi (Figura 22), percebemos em algumas personagens uma fisionomia mais próxima ao grotesco, porém a maior parte dos retratados não possui deformações faciais, o que nos indica que talvez ele tenha usado este recurso apenas para indicar idade avançada. Não obstante, talvez a rudeza nos traços dessas personagens preste-se a apontar o caráter e a idade, uma vez que para os inquisidores os maiores responsáveis pela injúria teriam sido Miguel Rodriguez, Fernán Baez e a viúva Beatriz Núñez (Figura 23). Todavia, encontramos nesta pintura alguns elementos nas indumentárias dos personagens que rementem a símbolos judaicos, como tzitzit e o tefilin $^{306}$ (Figura 24), e também o uso do puntero ou yad ${ }^{307}$ (Figura 25), simulando uma lança.

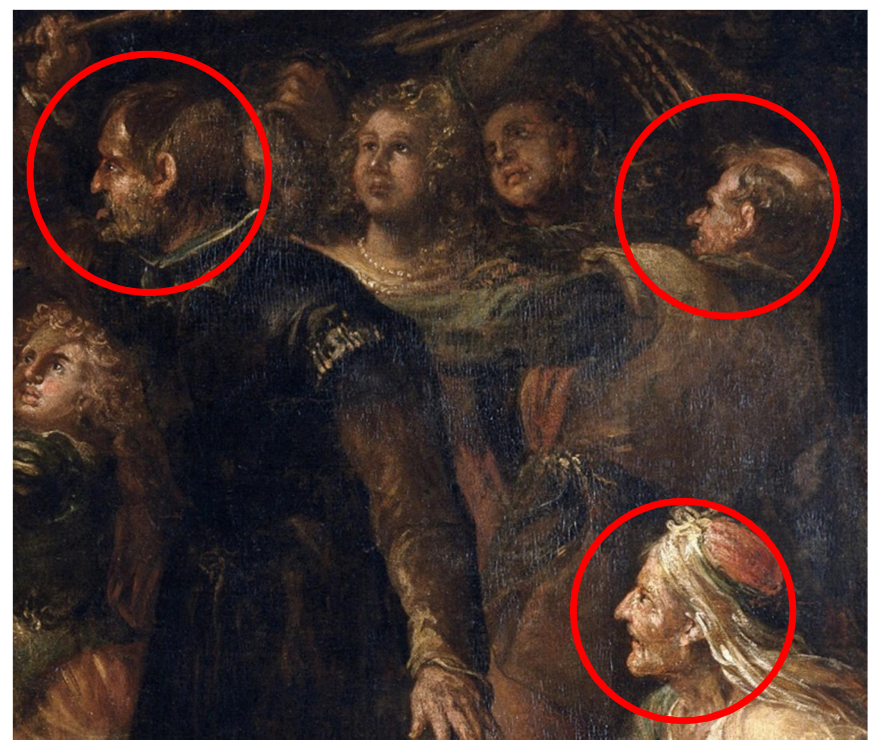

Figura 23 - Detalhe da Figura 22

\footnotetext{
${ }^{306}$ O tzitzit (franjas colocadas no talit, que servem como lembrança dos mandamentos de Deus: www.myjewishlearning.com/article/tzitzit/) e o tefilin (as duas caixinha de couro presa a uma tira, que podem ser usadas na cabeça ou no braço esquerdo: www.rechovot.org.br/web/estudos/simbolosjudaicos/simbolos-judaicos-tefilin/) são dois elementos da indumentária que simbolizam a fé hebraica. Apesar de não ser uma figuração mimética do que conhecemos hoje como tzitzit e tefilin optamos por mencioná-los, pois a tradição do uso destes elementos remonta à Antiguidade, e também sabemos que após a conversão forçada, algumas famílias as gerações seguintes tentaram manter as suas tradições e rituais, e ficaram conhecidos como marranos. PEDRERO-SÁNCHEZ, Maria Guadalupe. Os judeus na Espanha. São Paulo: Editora Giordano, 1994, p. 89.

${ }^{307}$ O puntero é um instrumento usado nas leituras cerimonias de livros sagrados tanto na fé judaica como cristã.
} 


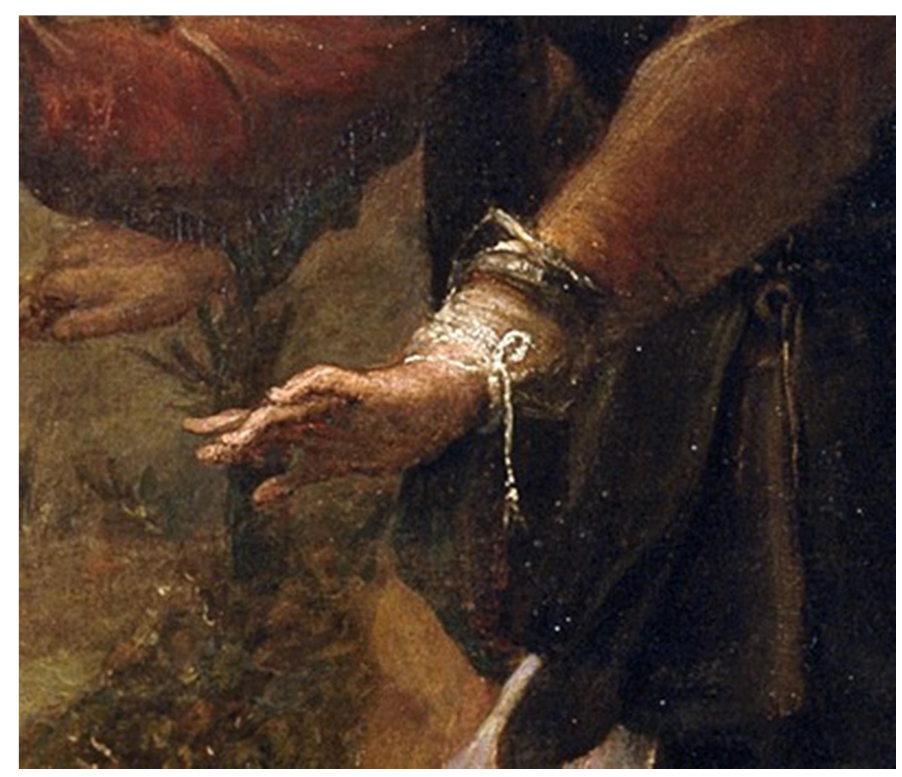

Figura 24 - Detalhe da Figura 22

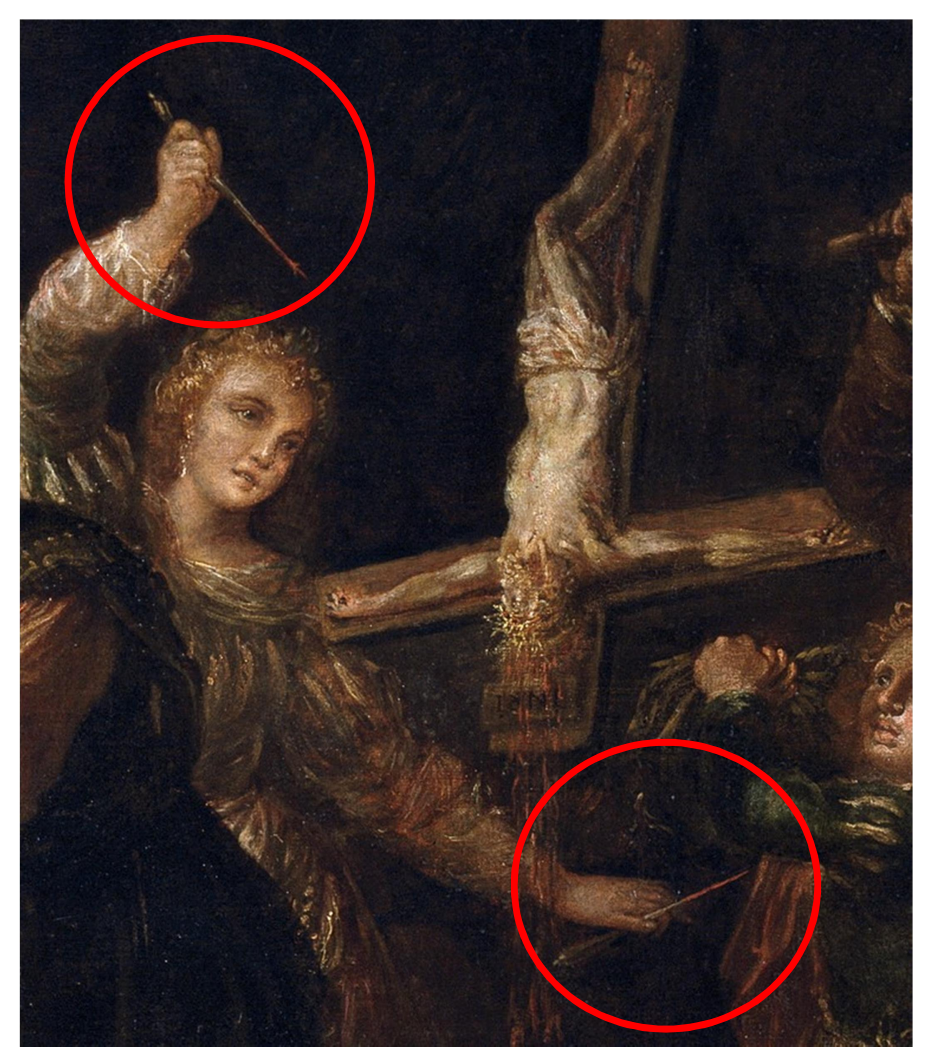

Figura 25 - Detalhe da Figura 22 


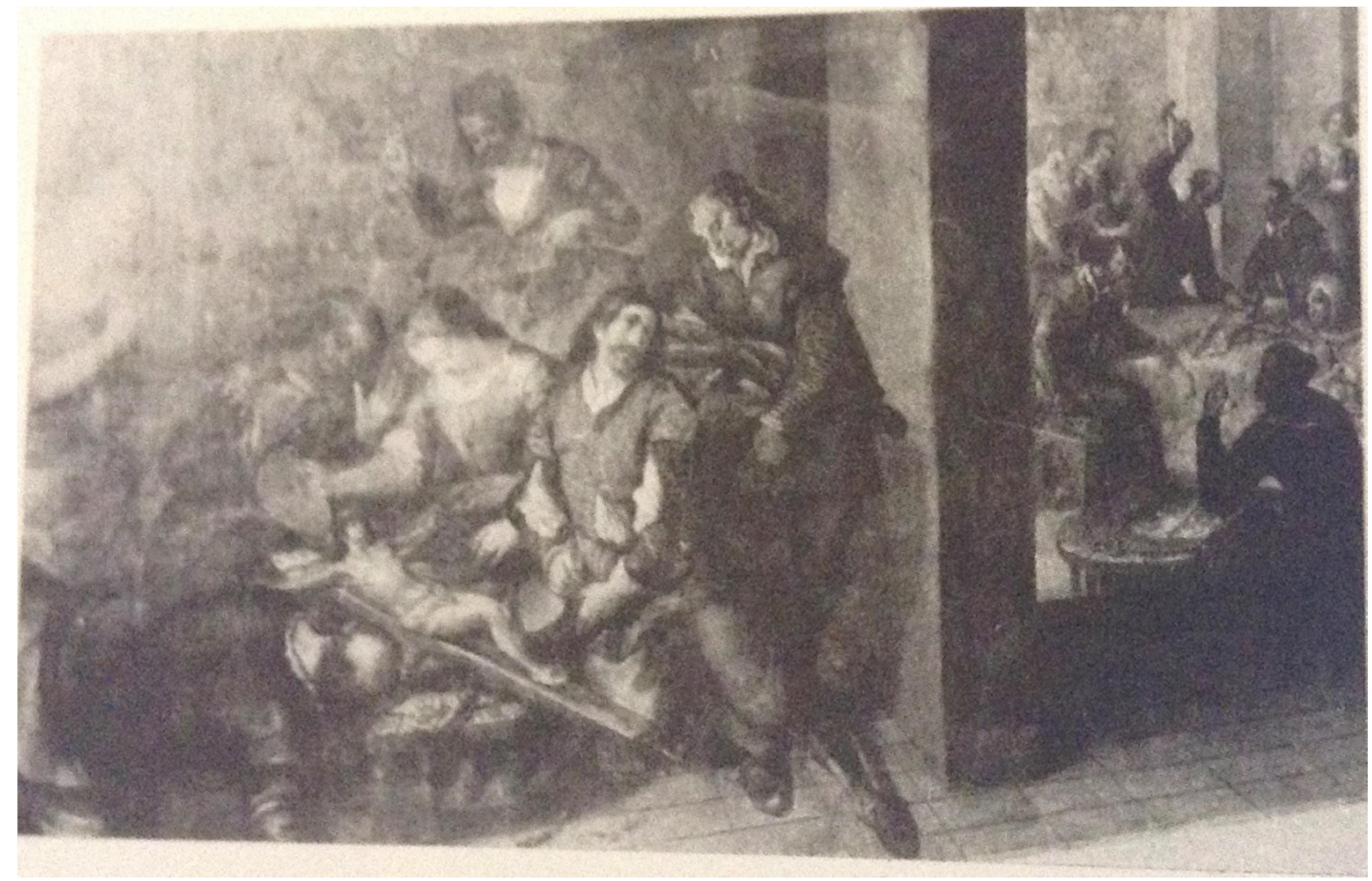

Figura 26 - Martirio del brasero del Cristo de la Paciencia, 1647-1651, óleo sobre tela, $171 \mathrm{com}$ x $296 \mathrm{~cm}$, Andrés de Vargas. Fonte: MUSEO DEL PRADO. Inventario general de pinturas II. El Museo de la Trinidad. Madrid: Espasa Calpe, 1991. 
Por fim, na pintura conhecida como Martirio del brasero del Cristo de la Paciencia de Andrés de Varga (Figura 26), dada a baixa qualidade da única foto existente da pintura, não podemos afirmar que todos os personagens figurados pelo pintor não possuam características fisionômicas deformadas. Apenas vemos dois momentos da agressão ao crucifixo, e na cena da direita do espectador, a personagem mais à frente, que está de perfil, parece fazer figa (Figura 27), como já vimos na pintura de Francisco Camilo.

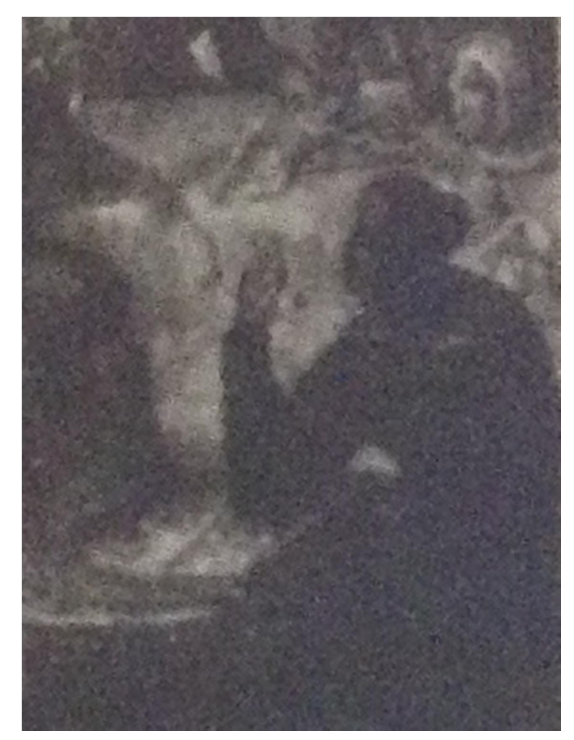

Figura 27 - Detalhe da Figura 26

Assim posto, nas pinturas mencionadas, as personagens figuradas, de acordo com as normas católicas e com a conduta social estabelecida por aquela sociedade, são hereges, falsos conversos, e desrespeitaram a imagem da figura central do cristianismo. Ora, diante desse hipotético ataque e das convenções formais referentes às representações pictóricas nos vem o questionamento acerca do motivo destes artistas não terem figurado os hereges com fisionomias deformadas. Em primeiro lugar, ao investigar esta pintura devemos levar em consideração a ambivalência como uma característica das imagens religiosas $^{308}$, o que de inicio nos impede de assumir que as fórmulas iconográficas seriam então obrigatórias, diferentemente do que disse Michael

\footnotetext{
${ }^{308}$ BONNE, Jean Claude. Entre ambiguité et ambivalence. Problématique de la sculpture romane. La part de l'oeil, 1992, 8, pp.147-164.
} 
Scholz-Hansel sobre as pinturas espanholas e o "costumbre obligatoria del siglo XVII de representar a los heréticos siempre com rostros desfigurados" 309 .

Todavia, não podemos deixar de assinalar a existência de diversas imagens em que a desfiguração do personagem infame é composta de maneira que as deformações fisionômicas representam seu desvio moral. Nas Cantigas de Santa Maria ${ }^{310}$ atribuídas ao rei de Castela Alfonso X, a iluminura que compõe o canto XII (Figura 28), o que Santa Maria mais despraz ${ }^{311}$, cuja temática também é a reencenação da Paixão através do ataque ao crucifixo, vemos a representação dos judeus com uma físionomia "deformada", de nariz adunco e a barba pontiaguda. Neste caso, tais atributos físicos foram figurados como elementos amplificadores do caráter herético, além das indumentárias com os típicos capuzes pontiagudos.

\footnotetext{
${ }^{309}$ SCHOLZ-HÄNSEL, Michael. Arte e Inquisición: Pedro Arbués y el poder de las imágenes. Anuario del Departamento de Historia y Teoría del Arte. Madrid: Universidad Autônoma de Madrid, 1994, ${ }^{\circ}$ 6, p. 210.

${ }^{310}$ Cantigas de Santa Maria, Códice Rico, T.Ms.T-I-1, Real Biblioteca del Monasterio de San Lorenzo de El Escorial, fol. 20v.

311 O poema narra um acontecimento na cidade de Toledo: ao celebrar a missa de Assunção de Nossa Senhora o arcebispo ouve o lamento da Virgem de como os judeus teriam matado seu filho, e que naquele momento um grupo de judeus estaria simulando a Paixão em um crucifixo. Ao findar a missa, o arcebispo conta aos párocos as palavras de Nossa Senhora, o que provocou a ira dos fiéis que correm ao local onde a profanação estava ocorrendo. $\mathrm{O}$ grupo de judeus foi pego em flagrante e atacado pelos cristãos. AMARAL. Debora G. P. A Iconoclastia nas Cantigas de Santa Maria. In: XXII ENCONTRO ESTADUAL DE HISTÓRIA ANPHU - SP. Santos: 2014. Anais eletrônicos... 2014. Disposnível: www.encontro2014.sp.anpuh.org/resources/anais/29/1406772434_ARQUIVO_artigoAnpuhDeboraGPA. pdf.
} 


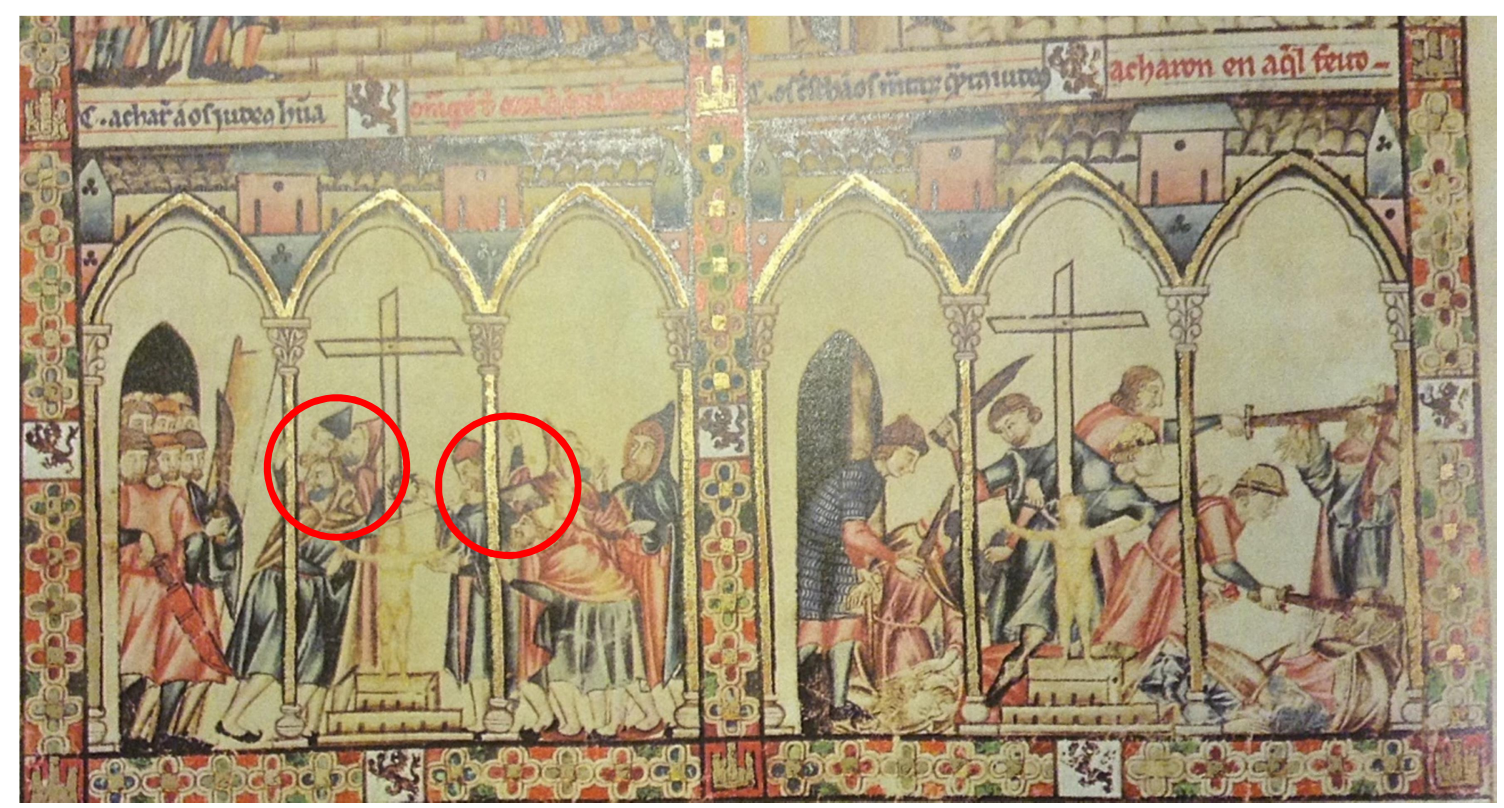

Figura 28 - Detalhe Cantigas de Santa Maria (Códice Rico) T. Ms.T-I-1, RBME, fl. $20 \mathrm{v}$.

Este recurso também pode ser observado em pinturas como o tríptico Ecce Homo (Figura 29), do Mestre de La Santa Sangre. Esta é uma obra da Escola Flamenga do inicio do século XVI, na qual podemos encontrar uma multiplicidade de deformações que compõem a figura do judeu perverso: nariz adunco, olhos arregalados, a falta de dentes delineando expressões de "rostros e talles feos" denotando assim a sua culpa na morte de Cristo. 


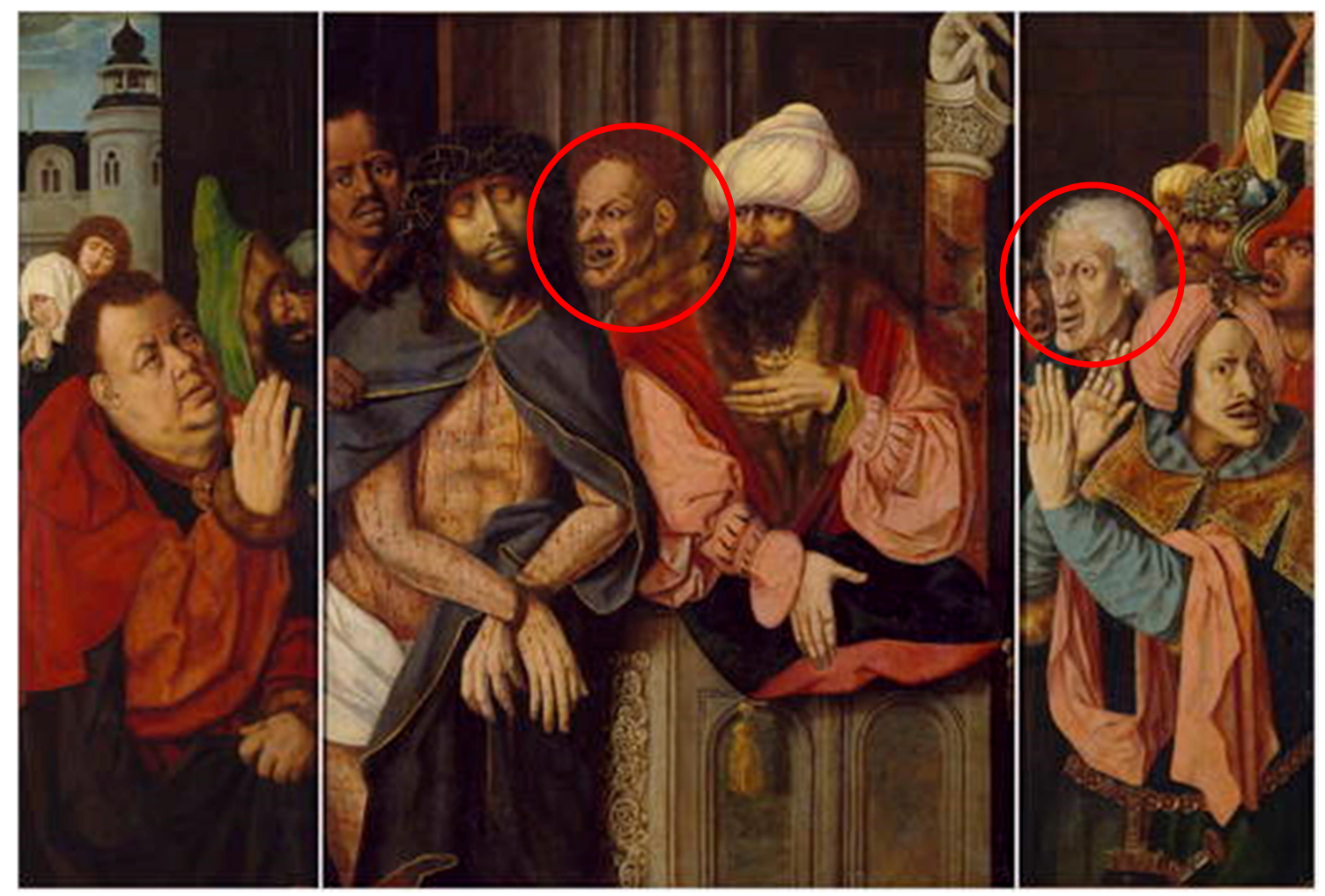

Figura 29 - Ecce Homo, 1520-1525, óleo sobre madeira, $109 \mathrm{~cm}$ x $167 \mathrm{~cm}$, Mestre de La Santa Sangre, Museu do Prado [P01559].

Também podemos apresentar a Santa Cena (Figura 30) de Vicente Carducho, na qual o pintor aplica esses conceitos iconográficos para conceber a figura de Judas. 


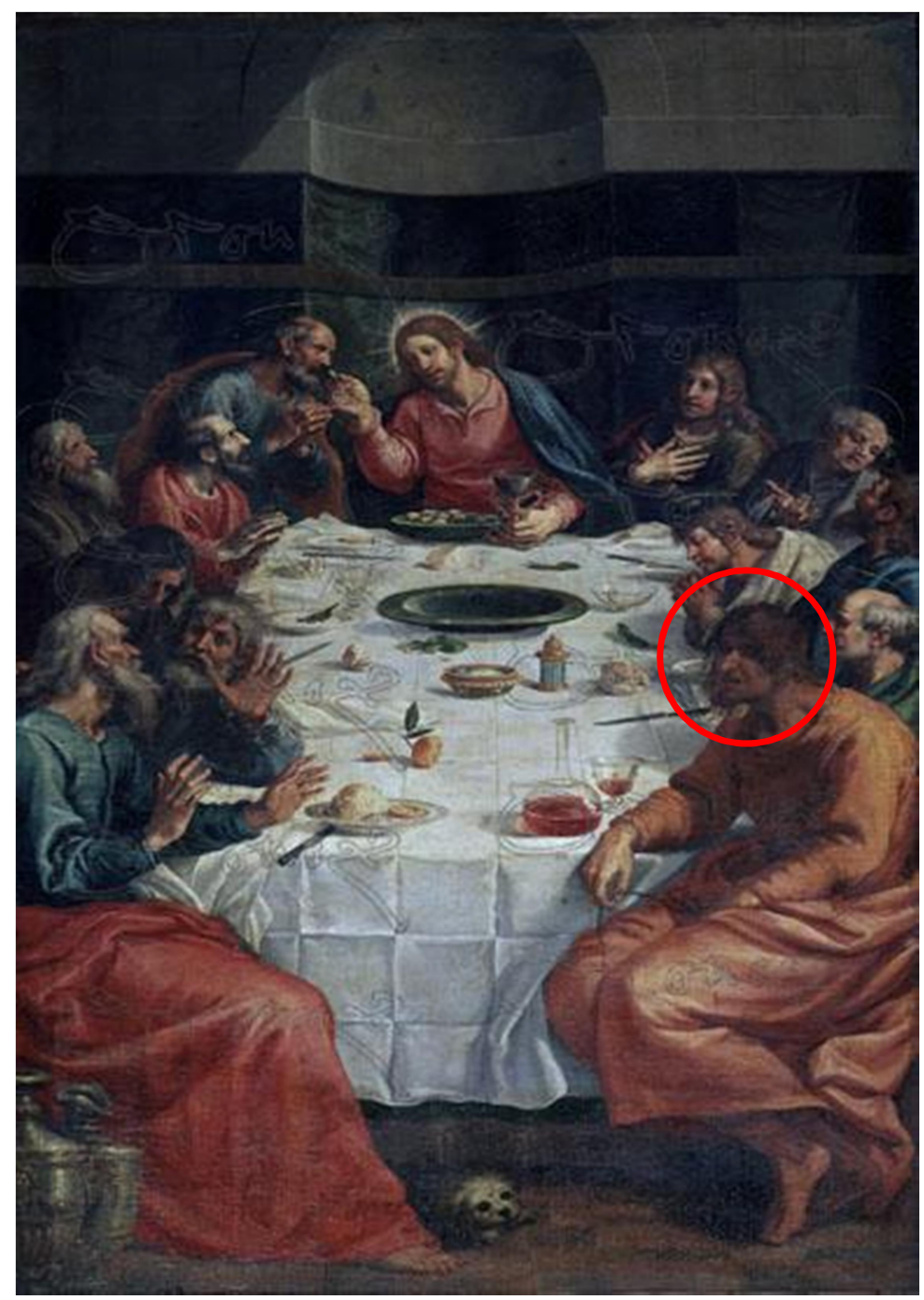

Figura 30 - Santa Cena, c. 1622, Vicente Carducho, Convento las Carboneras de Madri

Já tela conhecida como Martirio de San Bartolomé (Figura 31), de pintor anônimo, de acordo com a lenda de São Bartolomeu, o herege não seria um judeu, mas sim um incrédulo da Armênia. Mas da mesma maneira, o artista utilizou do artificio da deformação facial para conformar a natureza pecaminosa do assassino do santo. 


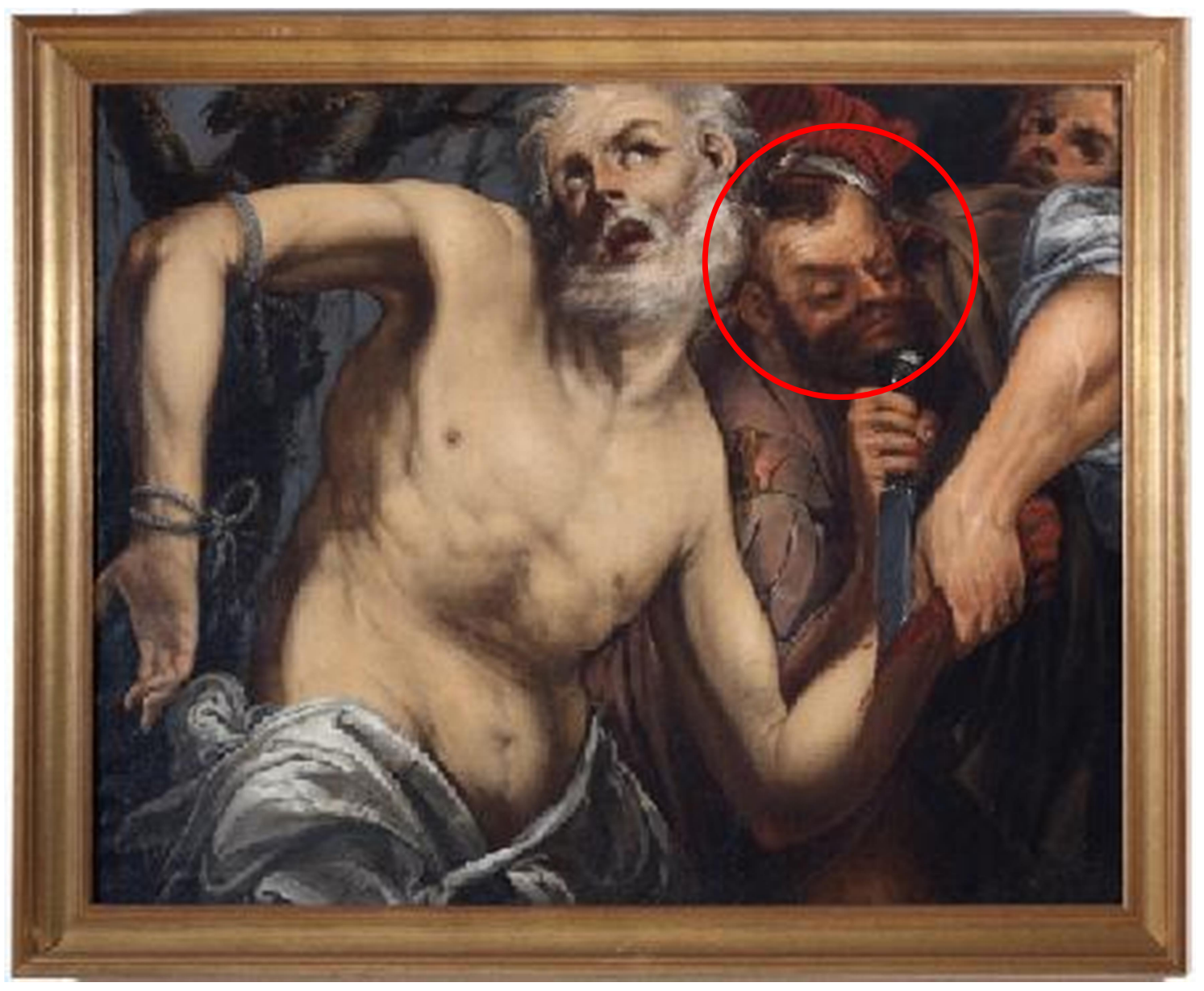

Figura 31- Martirio de San Bartolomé, século XVII, óleo sobre tela, 79,5 cm x 100 $\mathrm{cm}$, Museo de Huesca [00100].

Nessas imagens, além das fisionomias deformadas, os pintores fizeram uso de diversos outros recursos pictóricos, como cores, indumentárias, signos que eram entendidos também como atributos de judeus, mouros, judaizantes, hereges, etc.

Julio Caro Baroja, no primeiro livro da sua obra Los judios en la España Moderna y Contemporánea, faz uma pequena análise sobre as representações visuais dos judeus na Espanha. Caro Baroja apresenta vários exemplos, não apenas de obras espanholas, e discrimina obras em que as características físicas deformadas são usadas e aquelas nas quais tais atributos são minimizados ou simplesmente não aparecem ${ }^{312}$.

\footnotetext{
312 CARO BAROJA, Julio Caro. Los Judíos en la España Moderna y Contemporánea, 1972, pp. 95-
} 97. 

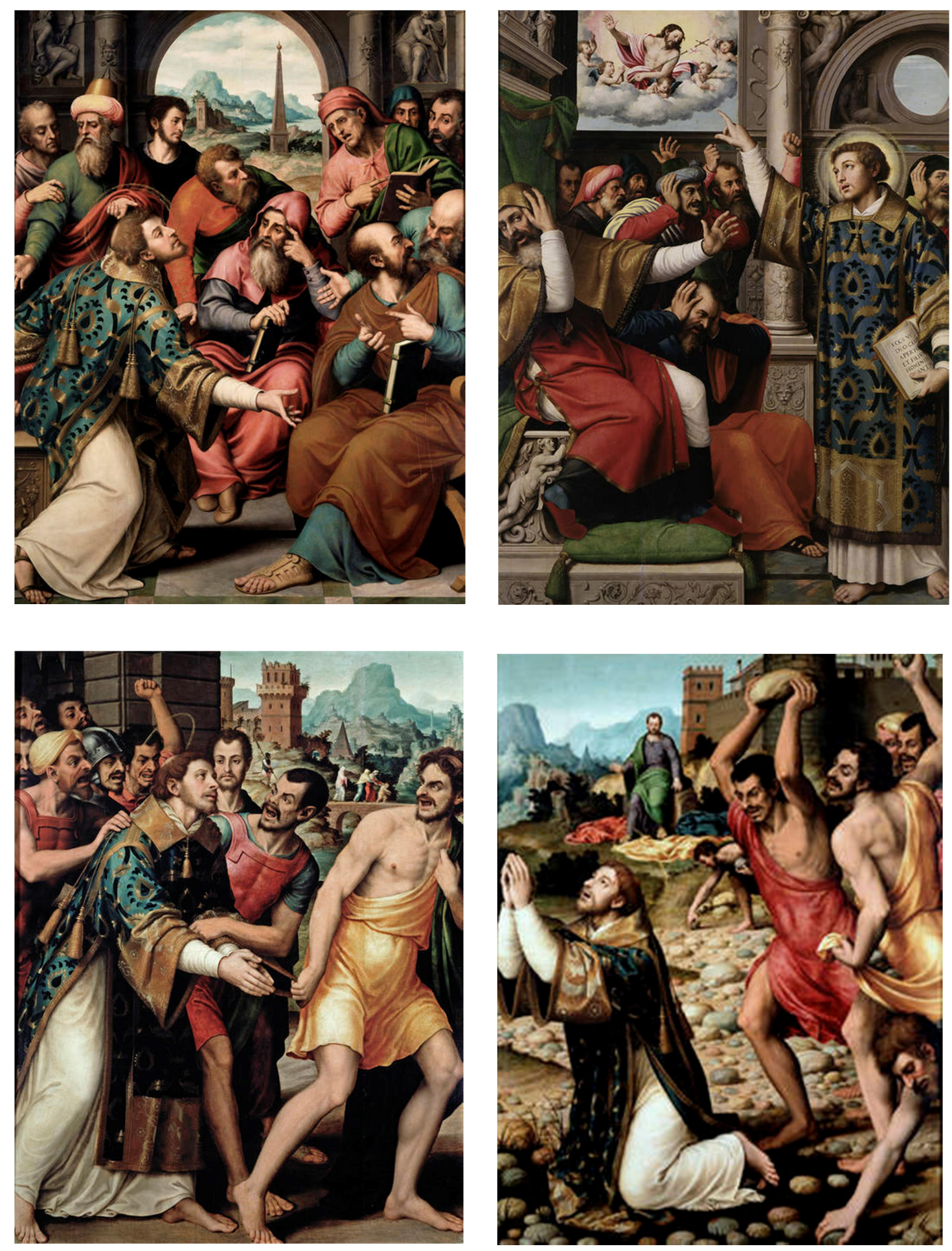

Figura 32 - Cenas do Retablo de San Esteban, 1562, óleo sobre madeira, Juan de Juanes, Museu do Prado [P00839-840-841-842]. 
Um caso interessante é o conjunto de pinturas de Juan de Juanes que narram o Martírio de São Estevão (Figura 32) Nesta série, podemos observar a mudança na representação dos judeus conforme o momento da narrativa da vida do santo ${ }^{313}$. Nos dois primeiros óleos sobre madeira, observamos que Juanes optou por figurar os judeus no templo rechaçando as palavras do santo ${ }^{314}$, bárbados, com vestes longas e cabeças cobertas. Mas suas fisionomias não apresentam deformidades, da mesma forma que também não possuem a "serenidade" e os traços delicados iguais aos que o pintor dedicou ao santo. Porém, quando Juanes representa os hebreus conduzindo o santo ao martírio e martirizando-o, sua opção foi conceber fisionomias com traços disformes e expressões "animalescas". Percebemos assim uma clara mudança de estratégia figurativa do artista, pelo que podemos inferir alguns motivos, como, por exemplo, serem os judeus que estão na sinagoga os sábios (Sanedrín), e os que cometem o martírio, homens do povo levados pela ira ${ }^{315}$.

Como havíamos comentado, também há imagens em que a representação da fisionomia do herege não foi composta por deformações físicas. O retábulo em relevo de arenito, construído no século XV para a igreja de São Miguel em Felanitx (Figura 33), na ilha de Mallorca, que no século seguinte foi transferido para o monastério de São Salvador, também figura o ataque a um crucifixo. Neste caso, a historiografia ${ }^{316}$ aponta que o retábulo representa a narrativa do milagre de Cristo de Beirute. No detalhe (Figura 34) que apresentamos aqui, percebemos que os homens esculpidos não trazem traços fisionómicos deformados, porém o que fica óbvio é a figuração da heresia por meio do ato iconoclasta.

\footnotetext{
${ }^{313}$ Apresentamos aqui apenas as pertencentes ao Museu do Prado, das nove pinturas elaboradas por Juan de Juanes que compõem a Vida de Santo Estevão, o primeiro mártir da cristandade.

${ }^{314}$ Sobre a primeira imagem: "Algunos doctores declaran su parecer hostil con el índice en posición horizontal — signo de afirmación discursiva - mientras con las palmas abiertas hacia el adversario manifiestan su repulsa, ofreciendo una imagen definida de la refutatio dialéctica, entendida como impugnación de las palabras del santo y afirmación de las propias". Já sobre a segunda: "Otros miembros del sanedrín, representados de perfil para mostrar claramente sus características raciales (algo que impera en el resto del ciclo) manifiestan su hostilidad y enfrentamiento cerrando con fuerza los puños y levantándolos hacia lo alto." GONZALES GARCÍA, Juan Luis. Ut pictura rhetorica Juan de Juanes y el retablo de San Esteban de Valencia. Boletín del Museo del Prado. Madrid, 1999, vol. 17, nº 35, pp 30 e 35. Neste ponto, discordamos do autor porque em outras pinturas do mesmo artista, tais características, como o nariz grande, aparecem em figuras importantes para o cristianismo, como Mateus, Bartolomeu, Tomás e Simão na obra Última Ceia, que também pertence ao Museu do Prado [P00846].

${ }^{315}$ Há uma série de questões que podemos levantar com estas imagens, mais adiante retornaremos a elas, ainda no âmbito da figuração da infâmia e da memória, mas apenas como parte do procedimento para análise de nosso objeto de pesquisa.

${ }^{316}$ ESPI FORCÉN, Carlos. Recrucificando a Cristo: los judíos de la Passio Imaginis en la Isla de
} Mallorca. Palma: Lleonard Muntaner Editor, S.L. 2009. 


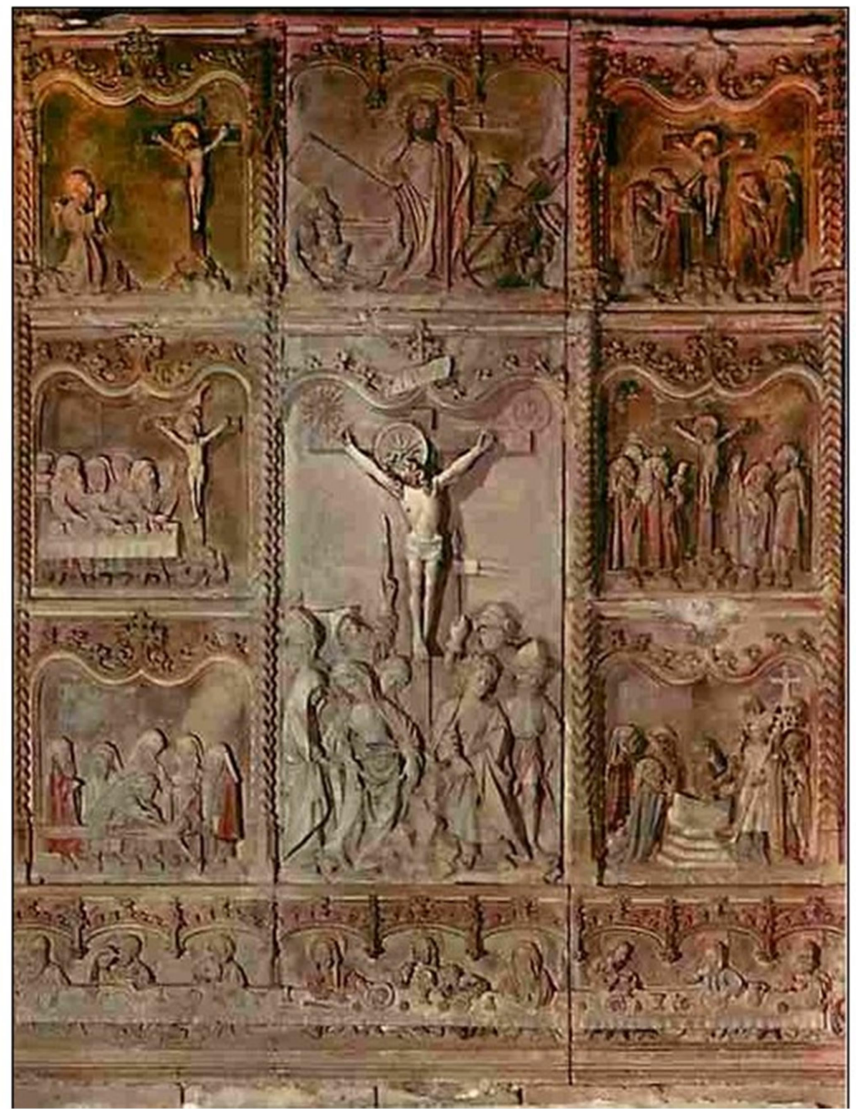

Figura 33 - Retábulo Passio Imaginis, sec. XV, relevo em arenito, Igreja de São Miguel em Felanitx.

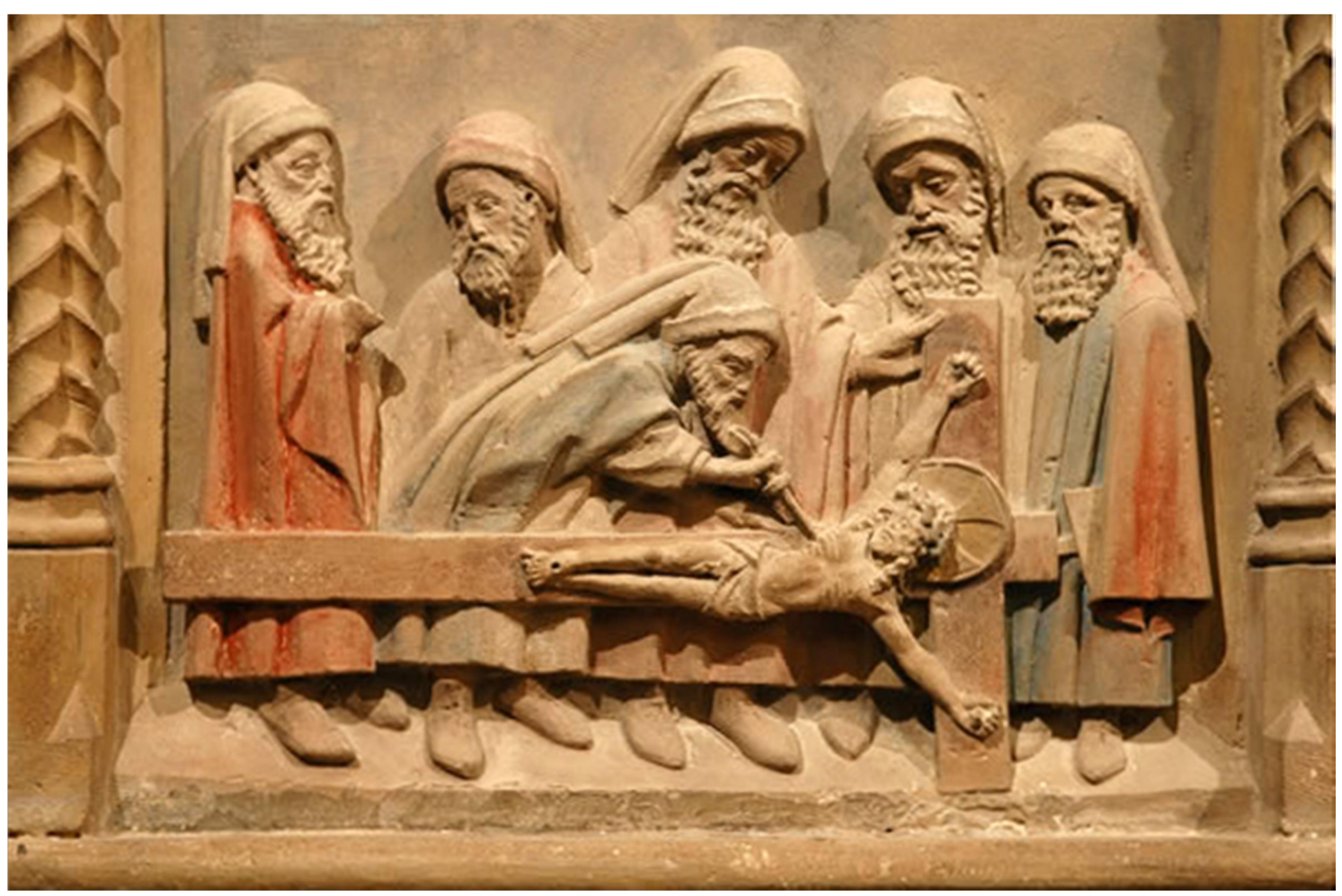

Figura 34 - Detalhe da Figura 33. 
No óleo Santa Cena, de Francisco Ribalta (Figura 35), vemos que o pintor optou por figurar Judas com traços físicos semelhantes aos demais apóstolos, mas o seu caráter judaizante aparece nas suas vestes, em tons amarelos. Como dito anteriormente, segundo Michael Pastoureau, o uso do amarelo denotaria a falsidade, a heresia e a traição $^{317}$, além disto, ele está em primeiro plano, o único aposto que olha para Cristo, e sua mão esquerda segura a bolsa que está presa em sua cintura, um signo de sua avareza - outro lugar-comum utilizado para configuração da imagem negativa dos judeus.

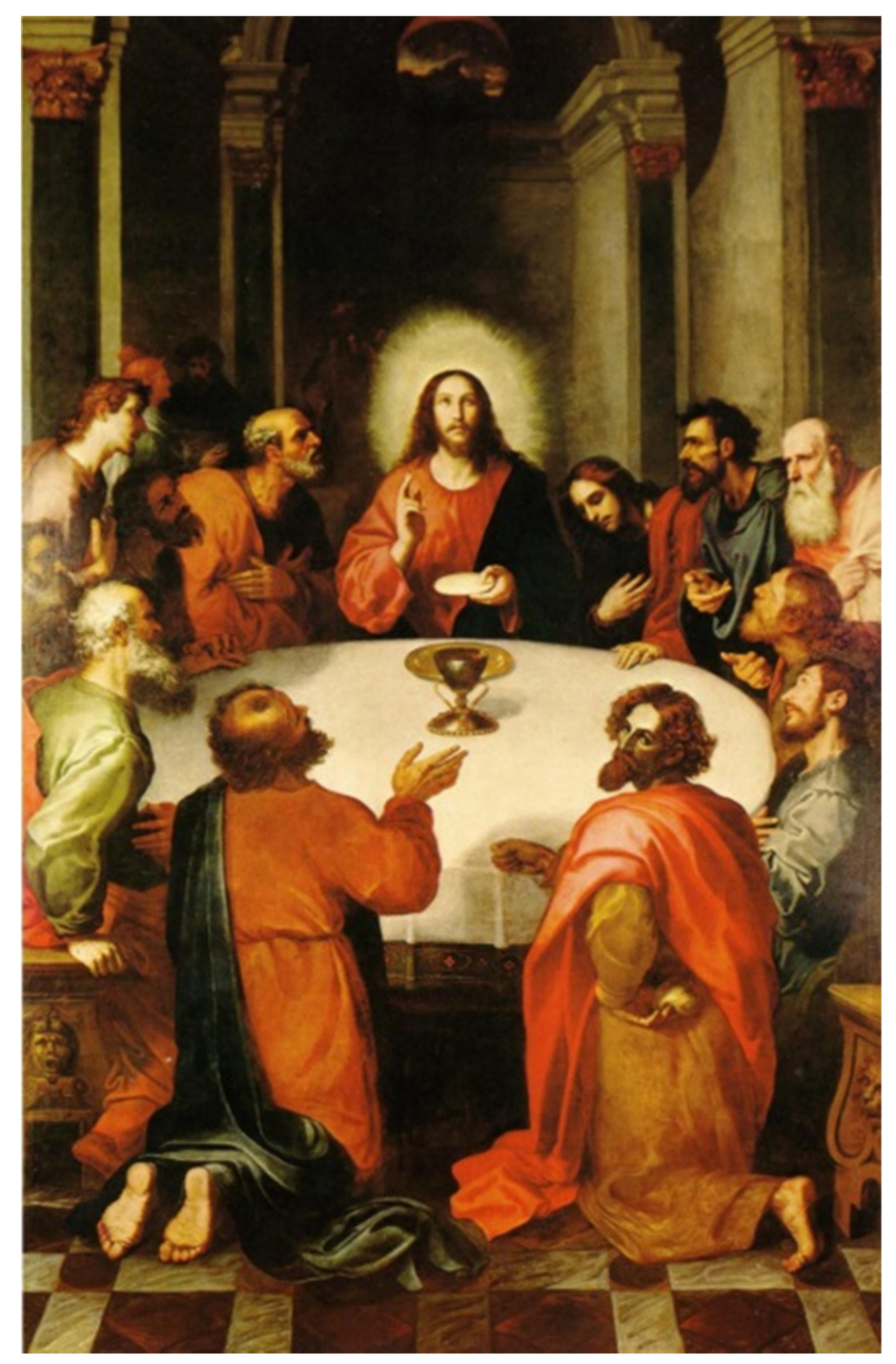

Figura 35 - Santa Cena, c.1606, óleo sobre tela, Francisco Ribalta, Colegio del Patriarca de Valencia.

\footnotetext{
${ }^{317}$ PASTOUREAU, Michel. Formes et couleurs du désordre: le jaune avec le vert,1983, p. 69.
} 
A pintura de Bartolomé Esteban Murillo, Martírio de San Pedro Arbués (Figura 36), descreve o martírio do então inquisidor de Aragão. A despeito das fontes históricas demonstrarem que as ações do inquisidor geraram descontentamento não só de conversos, mas também de cristãos-velhos, a culpa pelo seu assassinato recaiu sobre os primeiros, tantos marranos como mouriscos ${ }^{318}$. Neste caso, a solução pictórica de Murillo está na ação violenta e covarde em que os assassinos tomam de surpresa o santo, em um momento de oração, numa demonstração de desrespeito não só à autoridade religiosa como também ao ato de meditação.

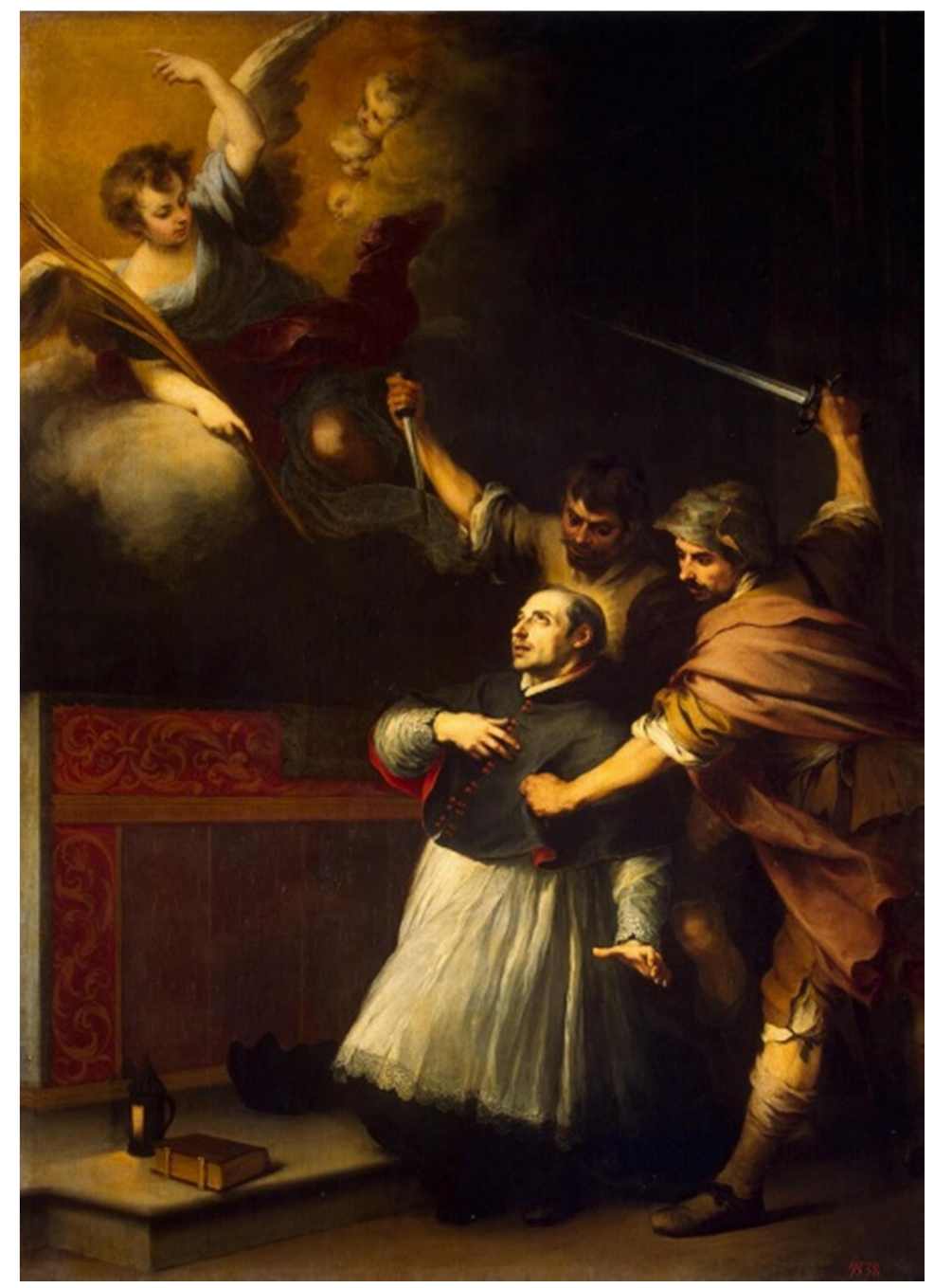

Figura 36 - Martírio de San Pedro Arbués, c. 1664, óleo sobre tela, 94,2 cm x $60 \mathrm{~cm}$, Bartolomé Esteban Murillo, Museu do Hermitage de São Petersburgo [ $\mathrm{n}^{\circ}$ inv. 448].

\footnotetext{
${ }^{318}$ SCHOLZ-HÄNSEL, Michael. Arte e Inquisición: Pedro Arbués y el poder de las imágenes, 1994, p. 206.
} 
Não podemos deixar de citar o óleo sobre tela Martírio de San Bartolomé (Figura 37) de Francisco Camilo, que mantém sua opção por não representar a fisionomia disforme do infame. Aqui a perversidade dos hereges está na atitude cruel em esfolar o santo ainda vivo.

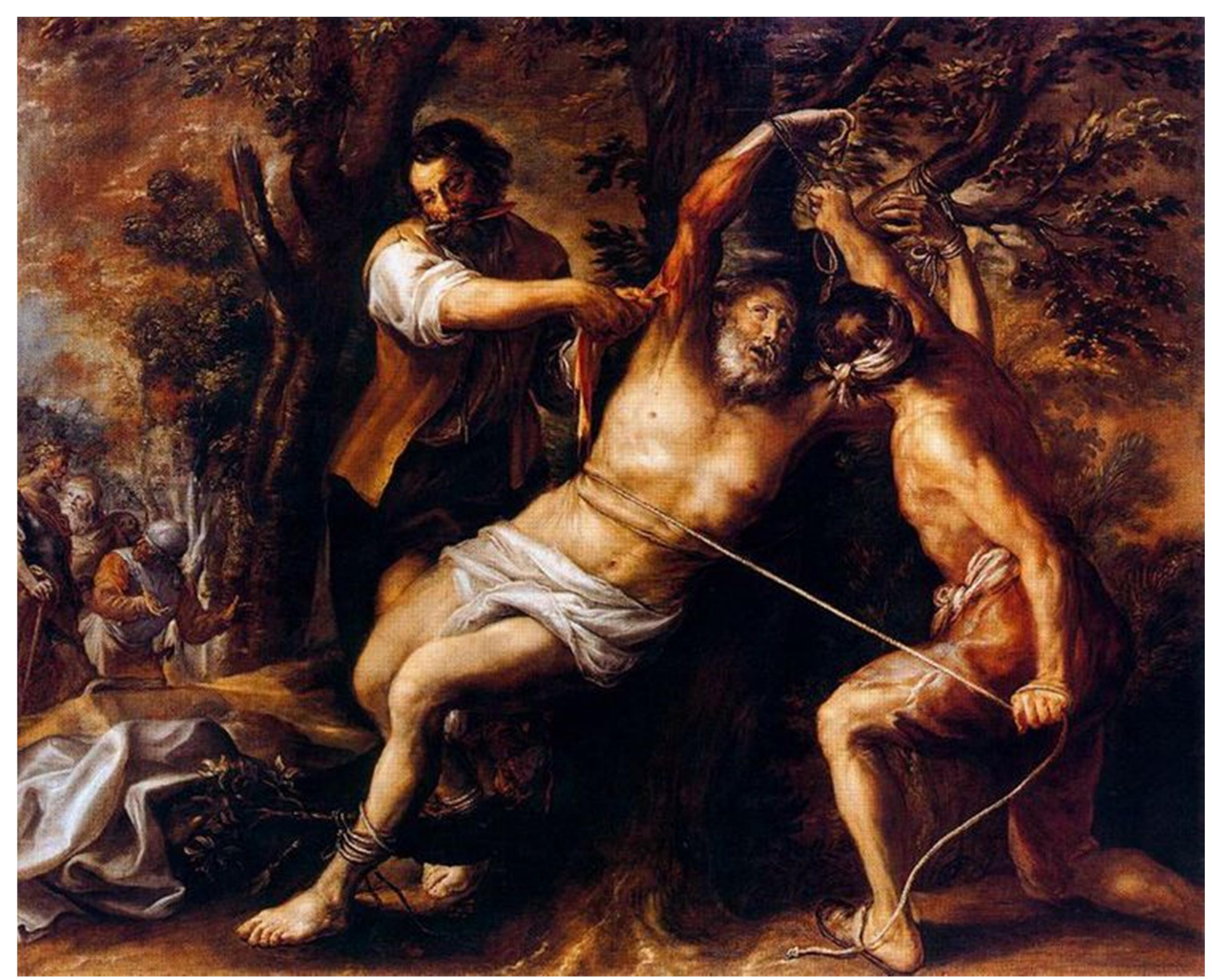

Figura 37 - Martírio de San Bartolomé, óleo sobre tela, $249 \mathrm{~cm}$ x $205 \mathrm{~cm}$, Francisco Camilo, Museu do Prado [P00623].

Voltemos, pois, ao nosso caso. O que podemos perceber é que a conotação infamante das pinturas que descrevem o caso do Cristo da Paciência não está na referência física judaizante. A infâmia é concebida pela ação desrespeitosa diante do crucifixo, como dito anteriormente, um topos configurado e retomado ao longo do período medieval, através das várias legendas sobre os milagres de crucifixos sangrantes, com a Passio Imaginis. 
Todavia, diferentemente do Cristo de Beirute, no caso do Cristo da Paciência a perfídia manteve-se mesmo diante do milagre. Estas pinturas, expostas em um templo expiatório, tornaram-se, pois, elementos de recordação das ameaças sofridas pela fé católica.

Como pudemos perceber, a despeito de todos os problemas sociais, políticos e econômicos entre os criptojudeus e os cristãos-velhos existentes na sociedade da Espanha do século XVII, não devemos esquecer o empenho da Coroa espanhola na afirmação da fé católica e do uso das imagens religiosas, bem como o combate aos casos de ataques iconoclastas ${ }^{319}$, que não se referiam somente aos conversos da fé hebraica, pois também temos conhecimento de casos de desacato aos objetos visuais entre os conversos do islamismo e protestantes ${ }^{320}$. Neste sentido, a opção por não identificar figurativamente um tipo físico e escolher a ação do agravo a Cristo e à imagem religiosa transfere maior valor à temática da importância da imagem religiosa $\mathrm{e}$ da figura de Cristo para o catolicismo, sem deixar de contemplar as questões dos hereges. Ao configurar de forma ambivalente o pecador, permite-se incluir na interpretação da pintura, além dos marranos, uma série de elementos que viviam à margem da sociedade espanhola e que atuavam como inimigos da fé, como os mouriscos, protestantes, ciganos, e até mesmo cristãos-velhos descontentes com os códigos sociais baseados na religião. Assim, as pinturas que adornaram a Capela do Santíssimo Cristo da Paciência de Madri conseguiram exacerbar o sentimento religioso e político e, ao mesmo tempo, reafirmar que o culto às imagens sagradas e aos objetos visuais é parte consubstancial da identidade católica da Espanha do Século de Ouro.

\section{Imagem da infâmia: translatio, memória e perpetuação da lenda}

A despeito da fisionomia, existiram outras formas de identificar plasticamente aqueles que estavam à margem da sociedade cristã, infamados por sua fé ou por sua descendência. Uma das consequências da disseminação dos mitos adversos iudeos foram as medidas de segregação como as do Concílio de Latrão, em 1215, que

\footnotetext{
${ }^{319}$ ESPESO PEREDA, Felipe. Las imagens de la discordia: politica e poética de la imagen sagrada en la España del cuatrocientos, 2007.

${ }^{320}$ Sobre a questão da imagem sagrada e os mouriscos e protestantes ver FRANCO LLOPIS, Francisco de Borja. Espiritualidade, Reformas y Arte en Valencia (1545-1609), 2007.
} 
estabelecia que em cada reino se deveria identificar seus súditos que professassem a fé judaica com elementos visuais em suas vestes. Na região da atual Espanha determinouse que os judeus deveriam ser identificados com um escudo amarelo costurado em suas roupas, no peito. Além do escudo, homens usariam capuz e mulheres, mantilhas da mesma $\operatorname{cor}^{321}$.

$\mathrm{Na}$ Espanha inquisitorial existiam várias formas de macular aqueles que haviam sido acusados de desrespeitar os preceitos católicos, como o uso dos sambenitos $^{322}$ (Figura 38 e 39) e corozas ${ }^{323}$ (Figura 39) nos Autos de Fé, com seus inúmeros rituais, procissões e símbolos em que os acusados deveriam ser apresentados. Ou seja, existia todo um aparato para se fazer ver infamados aqueles condenados, como podemos ler no excerto do texto Auto de la Fé celebrado en Madrid este año de MDCXXXII, de Gomez Mora:

La primera que se truxo al puesto para leerle su sentecia, fue Beatriz Nuñez, Portuguesa; ayudaronia a subir quatro Frailes de la Orden de S. Francisco, y Capuchinos, q por ser de edad de setenta años, las fuerças eran pocas. Llevaba las manos atadas, $y$ en ellas una Cruz verde, haziendo demostracion de arrepentimiento. Fue sacada por judaizante con coroça y sambenito, y acabada de leer la sentencia, fue entregada al braço seglar. Aviendo pronunciada los Tenientes la sentecia de muerte, y baxada del puesto, fue traida por el pasfadiço al segundo tablado, en que estuvo la Inquisicion, y Consejos, para tenerla aparte de los demás ${ }^{324}$

\footnotetext{
${ }^{321}$ MOLINA FIGUERAS, Joan. La Imagen y su contexto. Perfiles de la Iconografía antijudaíca en la España Medieval, 2007, p. 62.

${ }^{322} \mathrm{O}$ Sambenito era uma indumentária infamante, uma veste em forma de poncho, normalmente amarelo e com cruzes vermelhas. Geralmente anunciava o delito cometido e se o réu fosse relaxado ao poder secular também eram pintadas as chamas que o aguardavam.

323 Corozas era um chapéu de forma cônica que complementava a indumentária infamante dos réus da Inquisição da Espanha e também de Portugal.

${ }^{324}$ GOMEZ DE MORA, Juan. Auto de la fé celebrado en Madrid ensta año de MDCXXXII, 1632, fol.14r.
} 


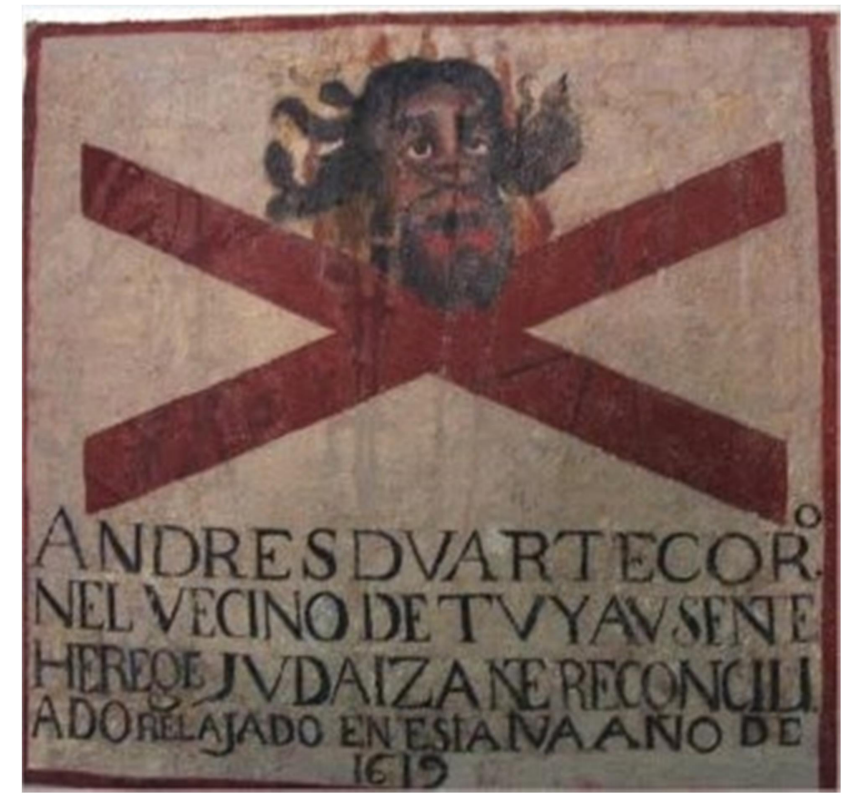

Figura 38 - Sambenito, sec. XVII, Museu da Diocese de Tuy.

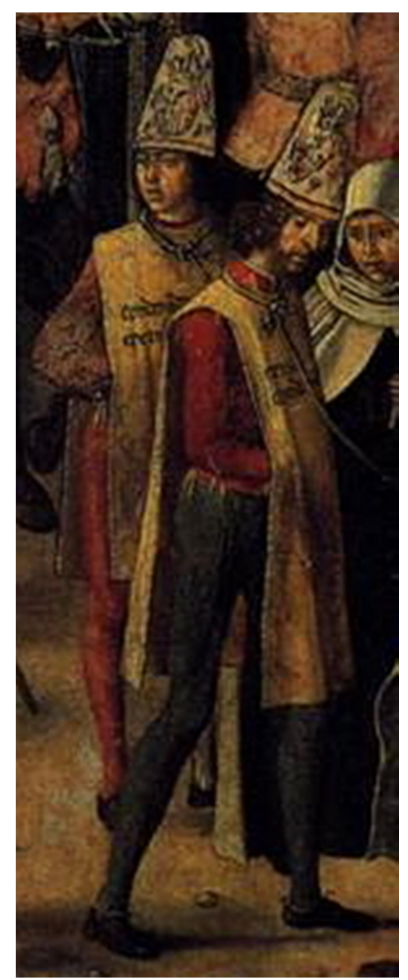

Figura 39 - Detalhe do Auto de Fe presidido por Santo Domingo de Guzmán, 14931499, óleo sobre madeira, $154 \mathrm{~cm}$ x $92 \mathrm{~cm}$, Pedro Berruguete, Museu do Prado [P00618]. 
No caso do Cristo da Paciência, após a sentença, ainda ocorreu o ritual de derrubada da casa da calle de las Infantas $^{325}$ e as várias festas de desagravo, cujos sermões já nos dão pistas da intenção da Igreja, junto ao Santo Ofício, de manter viva a identidade infamante dos condenados. Por fim, com a construção do convento e da capela, e a encomenda das pinturas, garantia-se assim uma memória das culpas dos criptojudeus e daquele "evento milagroso".

Se nos ativermos ao que Juan Ignacio Pulido Serrano escreveu em sua obra Injurias a Cristo: religión, política y antijudaímo em el siglo XVII a respeito dos fiéis ao contemplarem as imagens que ornavam a capela do Santo Cristo da Paciência:

cuando el visitante entraba en la capilla y caminaba a su alredor poniendo sus ojos en estos cuadros de enormes dimensiones, no podía evitar sumerdirse en el pasado, en una especie de túnel de tiempo que lo transpotaba hasta los días en que acaecieron aquellos supuestos sacrilegio. Y así, en la mente de muchos quedarían impresas las imágenes pintadas en los lienzos, ayudando a difundir la leyenda... ${ }^{326}$

Para o historiador, podemos dizer que uma das funções das pinturas seria a de memória - do passado recente para dar conhecimento deste caso para o futuro - da infâmia, mácula daqueles portugueses judeus conversos, que teriam insistido em desrespeitar a fé católica.

No entanto, quando lemos o artigo Os poderes da figura de Georges DidiHuberman, ao abordar a questão das imagens religiosas no Ocidente medieval, o autor comenta que as imagens religiosas não apenas representavam uma narrativa, mas também promoviam o "desvio visual de algo que não se encontra presente",327. Por uma perspectiva distinta da apresentada pela História da $\mathrm{Arte}^{328}$, esse desvio visual seria um recurso que os cristãos possuíam para conseguir contemplar a "verdade", que havia sido perdida com a Queda de Adão. Assim posto, por meio deste desvio também podemos

${ }^{325}$ GOMEZ DE MORA, Juan. Auto de la fé celebrado en Madrid ensta año de MDCXXXII, 1632, fol 20v: " la gente que non tenia herramientas con las manos arrancaba ladrillos, y piedras de su cimientos. Fue grande el concurso que obligó a poner guarda que defendiesse las bocascalles de las gentes, coches y caballos."

${ }^{326}$ PULIDO SERRANO, Juan Ignacio. Injúrias a Cristo: religión, política y antijudaísmo en el siglo XVII, 2002, p 327.

${ }_{327}$ DIDI-HUBERMAN, Georges. Poderes da figura. Exegese e visualidade na Arte Cristã, 1994, pp. 159. 328 “... a noção de figura escapa imediatamente aos modos triviais de pensamento com os quais nos limitamos muitas vezes a abordá-las na arte”. Foi, sem dúvida, com Alberti que a noção de figura iniciou esse abranger completo do aspecto 'figurativo' sobre a virtualidade 'figural' do sentido, qua a arte medieval - arte basicamente exegética - não tinha até aí...” DIDI-HUBERMAN, Georges. Poderes da figura. Exegese e visualidade na Arte Cristã, 1994, p. 167. 
compreender as pinturas que representam o Caso do Cristo da Paciência através do que Didi-Huberman denominou de translatio e memoria, quando os quadros não funcionariam somente como a representação da recente e hipotética injúria cometida ao crucifixo, mas ainda como um deslocamento para os tempos de Cristo e sua Paixão, seu sofrimento. Pois, como disse o autor,

Compreende-se que, nestas condições, a arte figurativa religiosa nunca se tenha limitado a construir os seus lugares como simples espaços unitários, e as suas temporalidades como simples histórias contadas. Estes lugares estabelecem entre vários espaços e várias histórias uma relação de associação, mesmo quando não existe senão uma única imagem. ${ }^{329}$

Assim podemos pensar não só na construção de um estereótipo judaizante, com seus rituais iconoclastas, mas a rememoração estereótipo do judeu deicida. As pinturas trazem a dor da imagem de Cristo (crucifixo) que teria sido causada pelos judaizantes, imagem esta que encarna a própria divindade ao sangrar e falar quando profanada. E, mesmo diante de tal revelação, eles se mantiveram cegos às evidências da "verdade" da fé cristã. Da mesma forma, elas também evocam a dor e o sofrimento infringido a Cristo no passado, também por hebreus que teriam insistido em não acreditar no Messias, o Deus que se fez homem pelo corpo de seu filho. Como podemos cotejar, no depoimento de um dos acusados, Fernán Báez:

Que estando en la Villa de Madrid, por el año pasado de 1630, éste y otras dos personas sus conjuntas, y otras tres de su nación, azotaron todos juntamente una imagen del Santo Cristo crucificado dos veces, dándole con unos abrojos y cordeles; colgándole para el dicho efecto de los pies o el pescuezo, executando con su danãda intención con sus sacrílegas y malditas manos, y renovando con suso dicho la pasión de Nuestro Señor Jesuscristo y lo azotes que sus antepasados le dieron perseverando todavía en la obstinada dureza de los suso dichos. ${ }^{330}$

Como já apontamos no segundo capítulo, devemos considerar a importância que a devoção cristocêntrica assumiu para a piedade espanhola. O culto ao sofrimento, às chagas e ao sangue de Cristo manifestou-se de inúmeras formas, e uma destas expressões foram as inúmeras pinturas cujos temas foram a Paixão, Cristo sendo flagelado e humilhado, bem como o uso dos crucifixos nas cerimônias religiosas,

\footnotetext{
${ }^{329}$ DIDI-HUBERMAN, Georges. Poderes da figura. Exegese e visualidade na Arte Cristã, 1994, p. 169.

${ }^{330}$ AHN Inq. Leg. 140. Caixa 1. Exp. 4b. Proceso de Fernando Báez (Audiência de 19 de agosto de 1631), fols. 66r-vto. Apud: PULIDO SERRANO, Juan Ignacio. Injúrias a Cristo: religión, política y antijudaísmo en el siglo XVII, 2002, p. 145.
} 
despertando nos fiéis tanto sua compaixão como o ódio e o medo daqueles verdugos. Destas pinturas podemos apontar como exemplo o pequeno óleo sobre madeira do século XVI, La coronación de espiñas y los escárnios, de pintor anônimo (Figura 40). Nesta pintura vemos Cristo sentado e vendado, sofrendo escárnio por seus sayones (os executores). Na pintura Cristo Conducido a la flagelación (Figura 41), também de mestre anônimo, ao centro está Cristo, de corpo inteiro, sendo conduzido com firmeza por seu carrasco com fisionomia alegre, quase animalesca. À frente de Cristo, vemos outro sayón com sua espada e ao chão, um açoite.

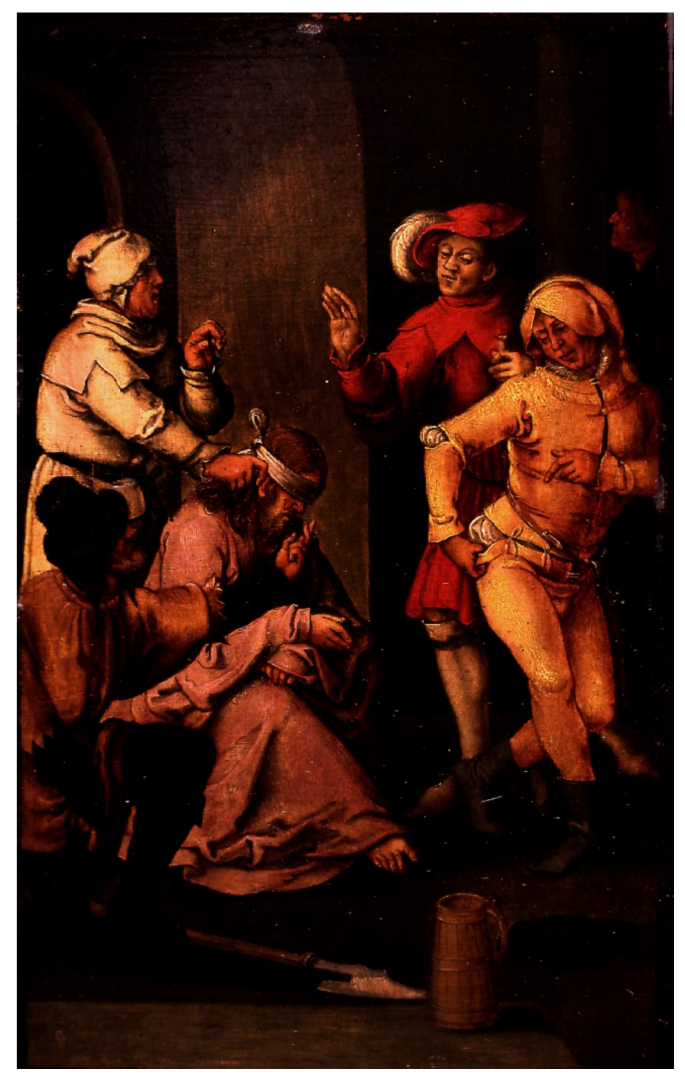

Figura 40 - La coronación de espiñas y los escarnios, séc. XVI, óleo sobre madera, 9,3 cm x 14,7 cm Museu Lázaro Galdiano [02769] 


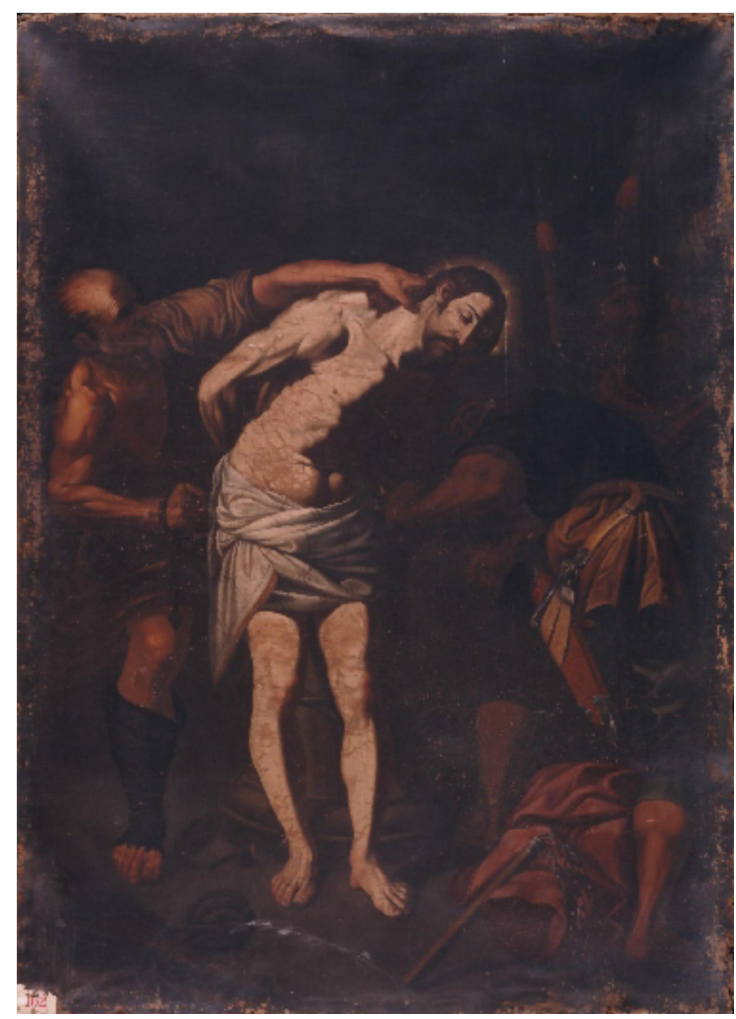

Figura 41 - Cristo Conducido a la flagelación, segunda metade do século XVII, óleo sobre tela, $183 \mathrm{~cm} \times 134 \mathrm{~cm}$, Museo de Bellas Artes de Córdoba [CE2234P].

Além destas pinturas, podemos apresentar inúmeras imagens que ornaram capelas e igrejas em todo o território espanhol, que em certa medida mantinham aceso o imaginário deicida e do sofrimento causado pelos judeus. 


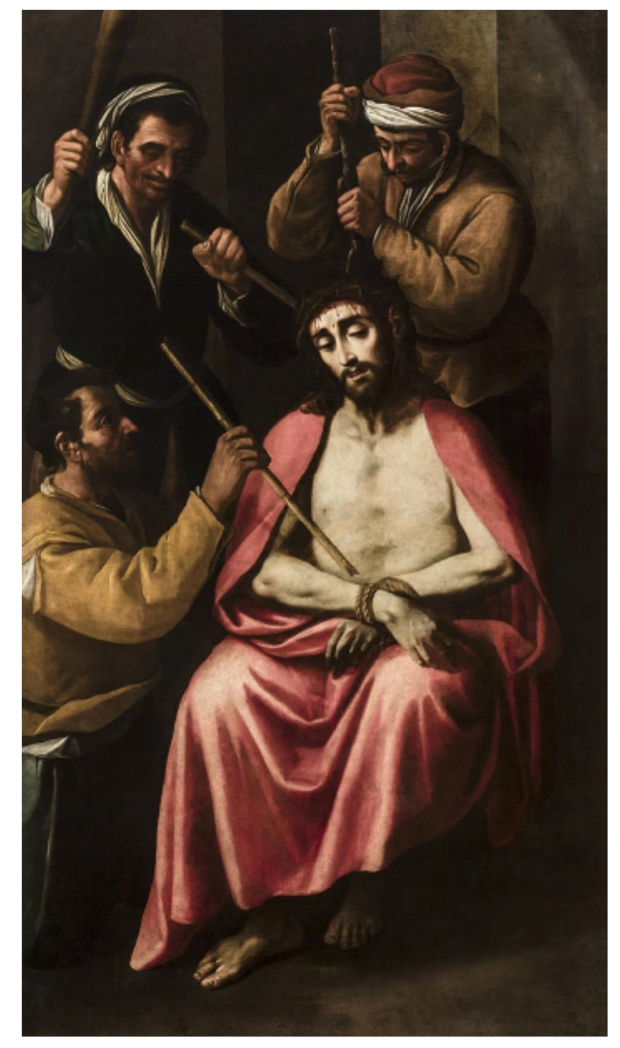

Figura 42 - Coronación de espinas, 1631, óleos sobre tela, $221 \mathrm{~cm}$ x $120 \mathrm{~cm}$, Francisco Pacheco, Museo de Bellas Artes de Sevilla [CE0075P].

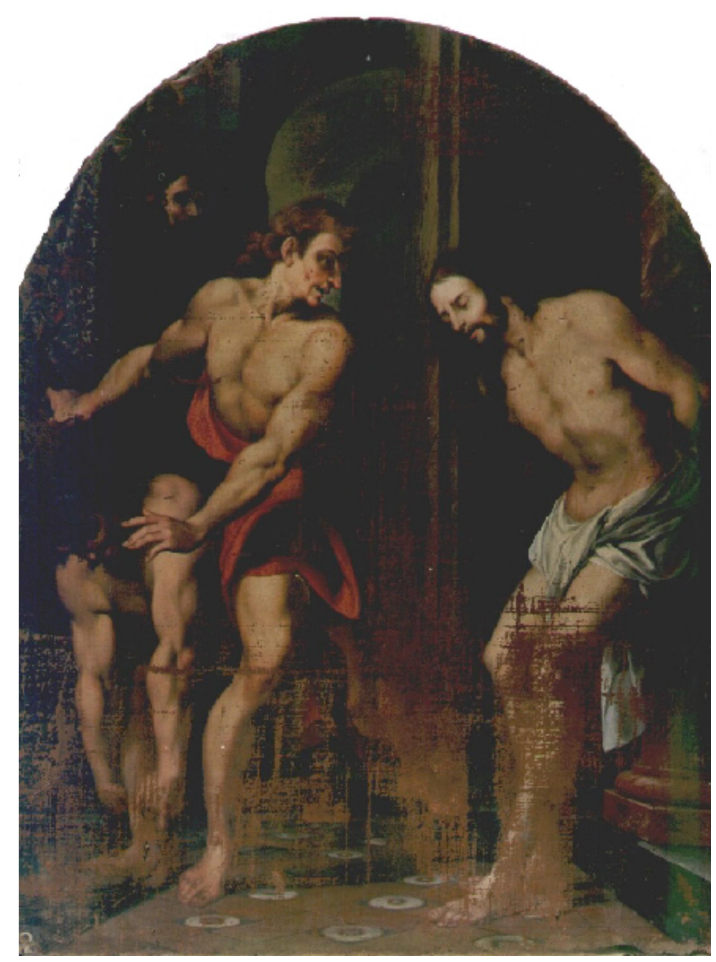

Figura 43 - Flagelación de Cristo, segunda metade XVII, óleos sobre tela, $201 \mathrm{~cm} \mathrm{x}$ $162 \mathrm{~cm}$, Fray Juan del Santísimo Sacramento, Museo de Bellas Artes de Córdoba [CE2117P]. 


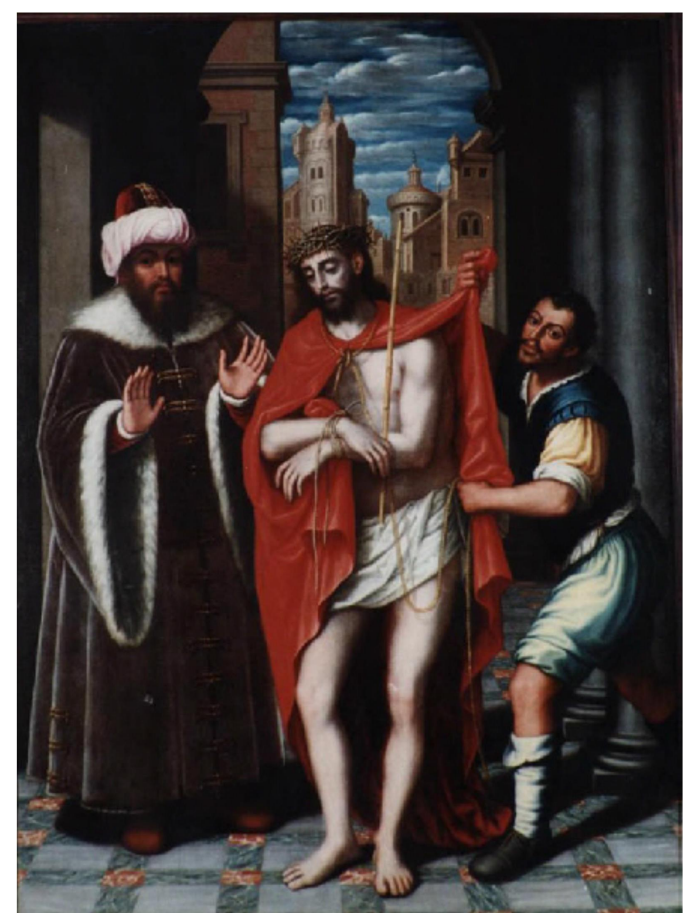

Figura 44 - Ecce Homo, 1626-1627, óleos sobre tela, $278 \mathrm{~cm}$ x $200 \mathrm{~cm}$, Fray Juan Sánchez Cotán, Museo de Bellas Artes de Granada [CE0122].

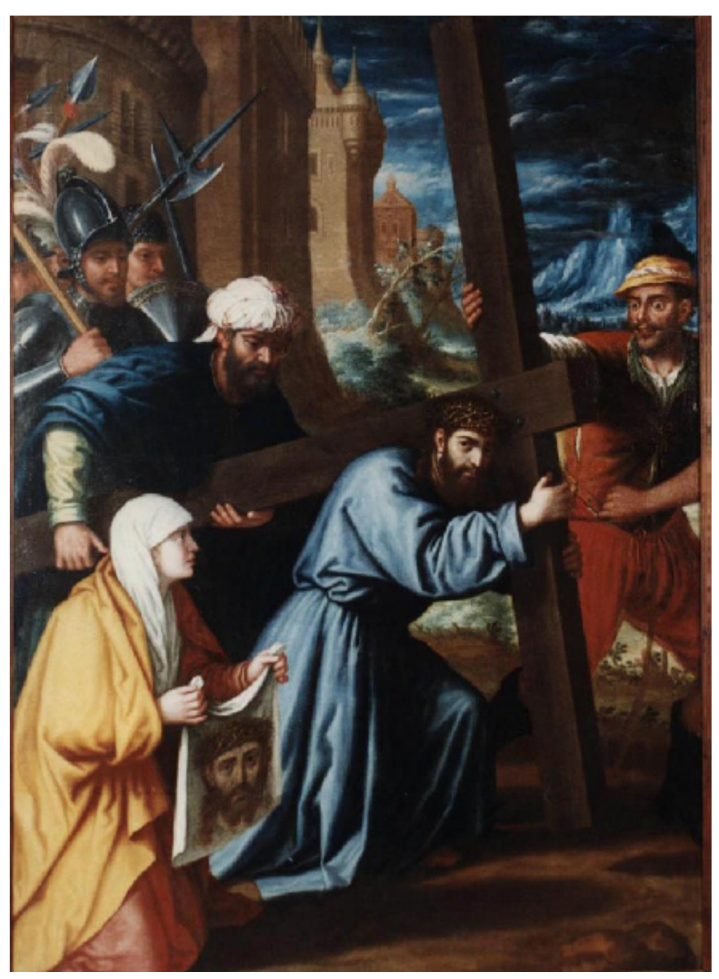

Figura 45 - Cristo con la Cruz a Cuesta, 1626-1627, óleo sobre tela, $278 \mathrm{~cm}$ x $201 \mathrm{~cm}$, Fray Juan Sánchez Cotán, Museo de Bellas Artes de Granada [CE0123]. 
Ou seja, as pinturas que tematizam a Paixão faziam parte da engrenagem devocional e ajudavam a manter presente para o fiel espectador o maior evento para a fé cristã, que é Cristo morrer em prol da salvação da humanidade. Da mesma maneira podemos interpretar as imagens do caso do Cristo da Paciência.

Assim, com o agravo ao crucifixo, fez-se de Madri La Nueva Jerusalén, como relembrou 77 anos mais tarde o padre capuchinho Mateo de Aguiano, com a obra que descreveu os supostos fatos ocorridos na calle de las Infantas, além da condenação, das comemorações e da construção da igreja e do convento, da devoção ao Cristo da Paciência e dos supostos milagres que lá acontecerem.

De donde arguyo, que no acaso, fino con singular Providencia, quiso su Magestad Divina, que fe erigieíse en el centro de España, y Corte gloriosa de ella (en Madrid, digo) otra Nueva lerusalèn no ingrata, como la de Judèa, en que fue crucificado, y murió para redimirnos, y darnos la vida de la gracia; sino muy agradecida á sus Divinos favores, y muy apreciadora de sus finezas, y misericordias; y que siempre fe ha esmerado en solicitar los Desagravios de las injurias, que los pérfidos Hebreos han hecho à nuestro Divino Redemptor Jesu Christo $^{331}$.

A Nova Jerusalém madrilena se manteve por meio do complexo religioso dedicado ao Cristo da Paciência, com sua capela ornada com as grandes pinturas. Esta Nova Jerusalém rememorava a primeira até em suas ausências, como diz Anguiano ao comparar as duas "histórias" sobre a inexistência de vestígios do sangue que a imagem teria vertido:

Hasta en esto quiso Dios asimilar esta Segunda Jerusalén con la Primera porque assi como de las Sangré que salió del verdadero Cuerpo de Christo Señor Nuestro; no quedo parte alguna en la tierra; assi tan poco la ay, ni se ha hallado, de que aquella de su Sagrada Imagen ${ }^{332}$

Devemos ainda ressaltar que o trabalho da imagem, da translatio e memória da mácula deicida não foi uma inovação das pinturas que aqui estudamos, pois, já no

\footnotetext{
331 ANGUIANO, Mateo de. La nueva Jerusalen en que la perfidia hebraica reitero con nuevos ultrages la passion de Christo en su ss. imagen. del Crucifixo de la Paciencia en Madrid, 1709, p. 216.

${ }^{332}$ ANGUIANO, Mateo de. La nueva Jerusalen en que la perfidia hebraica reitero con nuevos ultrages la passion de Christo en su ss. imagen. del Crucifixo de la Paciencia en Madrid, 1709, p 281. Nesta passagem, Anguiano está falando de não ter ficado o sangue de Cristo no solo do seu calvário, assim como na casa do sacrilégio, porque os acusados teriam lavado o chão (um motivo de não existir evidência do hipotético milagre). Mas na sequência de seu texto ele apresenta algumas catedrais que possuem relicários contendo, supostamente, o sangue de Cristo, e também fala da existência de relicários contendo o sangue que a imagem de Cristo de Beirute teria jorrado.
} 
século XIII, percebemos que a comunidade cristã espanhola insistiu em revisitar este mote, através da produção de inúmeras imagens em que o elemento judeu fora figurado como o cruel inimigo do cristianismo, como nas imagens já citadas do Canto XII, o que Santa Maria mais despraz, das Cantigas de Santa Maria (Figura 28 - Detalhe Cantigas de Santa Maria (Códice Rico) T. Ms.T-I-1, RBME, fl. 20v.) e da Passio Imaginis (Figura 33).

Nessas imagens, produzidas ao longo da Baixa Idade Média espanhola, vemos a permanente retomada do pensamento de que os judeus, e depois os cristãos-novos, são transgressores; que com violência tentam combater a verdade revelada, tanto por Cristo, como pelas inúmeras imagens religiosas que se manifestaram no mundo terreno. Além disso, há a alusão frequente, mesmo sem ser mencionado, ao caso do Cristo de Beirute, vastamente reinterpretado ou rememorado em diversos locais da Espanha, com diferentes algozes, como maus cristãos, muçulmanos, mouriscos, protestantes.

Neste sentido, podemos compreender que, em nossas pinturas, a figuração dos hereges poderia ser entendida de forma ambivalente e a narrativa figurada pode ser interpretada também pelo desvio para o tempo passado, fazendo parte da história sagrada. Como já disse William Christian, para além da veracidade dos ataques e dos milagres das imagens, a população estava sempre receptiva a essas lendas, e ao acreditar que tais acontecimentos sobrenaturais na Espanha seriam escolhas de Deus, na interpretação de muitos clérigos este seria um sinal de que aquele local seria mesmo como Jerusalém. ${ }^{333}$

\footnotetext{
333 "But the whodunit question should not distract us from the central cultural fact, which was the eager receptiveness, the active collaboration in the certification of these events and the promotion of these images by the town authorities and the town citizens, rooted in the constant, urgent search for divine helpers on a corporate and personal level, and in the highly tuned sense in Spain's city, town, and village states of being God's chosen place. Later clerical interpreters of these events pointed out that if Christ wept there, then the town was like Jerusalem. But the template of town as Jerusalem, through the erections of Calvaries and stations of the cross and the entire intense sequence of Holy Week ceremonies and processions, already applied to virtually every nuclear settlement in Spain, a great many accompanied by flagellants; by these image activations the template was actualized and confirmed in a dramatic way. The images involved became proofs, relics and trophies, demonstrations of the power of images in the face of local and international religious enemies, but especially demonstrations of God's vital residence in their particular place". CHRISTIAN, Willian A. Images as Beings in Early Modern Spain, 2009, pp. 9495 .
} 


\title{
5.3. A imagem do crucifixo milagroso
}

Ao questionar as interpretações teóricas da história da arte derivada do humanismo italiano, Didi-Huberman, em sua obra Diante da Imagem, nos apresenta uma categoria distinta de imagens religiosas, que ele denominou de "prototípicas":

\begin{abstract}
...essas imagens raras, essas imagens de exceção frente às quais o cristianismo, oriental e depois ocidental, terá de inicio reivindicando uma relação de culto, o que supunha duas coisas, pelo menos: primeiramente, que essas imagens tocassem a região do maior desejo, região impossível de todas as outras imagens, região na qual a imagem, 'milagrosamente', se fazia ela mesma virtu e potência de encarnação... Por outro lado, que essas imagens raras, ao tocarem limites, indicassem fins - ainda que insustentáveis - para todas as outras imagens da arte. $^{334}$
\end{abstract}

Nesta categoria de imagens enquadram-se aquelas que por motivos sobrenaturais seriam capazes de exercer milagres. Podemos falar aqui tanto das imagens aqueiropoiéticas, não feitas pela mão dos homens, como daquelas de manufatura humana que adquiriram qualidades hierofânicas.

Conforme explica o historiador francês Jean-Marie Sansterre em seus inúmeros artigos a respeito das imagens milagrosas, em uma série de lendas que circularam no mundo medieval e moderno cristão algumas imagens milagrosamente teriam adquirido poder - de suar, sangrar, chorar, lactar, mover, falar, etc. - ativadas por seus protótipos celestes. E em outros casos algumas imagens, mesmo sem adquirir características "viventes", teriam a capacidade de curar, salvar povos de guerras, ou seja, mesmo fisicamente passivas, possuiriam a virtude celeste de interferir no mundo terrestre ${ }^{335}$.

São poucas as reflexões historiográficas a respeito deste poder milagroso que algumas imagens religiosas adquiriram. Mais escassas ainda são as ponderações elaboradas por eclesiásticos, desde o cristianismo primitivo até o inicio da modernidade. O que podemos perceber é que esse tema gerou muitas polêmicas, e por este motivo

\footnotetext{
${ }^{334}$ DIDI-HUBERMAN, Georges. Diante da Imagem: questão colocada aos fins de uma história da arte, 2013, pp. 244-245.

335 SANSTERRE, Jean-Marie. La imagen activada por su prototipo celestial: milagros occidentales anteriores a mediados del siglo XIII. Codex Aqvilarensi, 29: Imágenes en acción. Actos y actuaciones de las Imágenes en la Edad Media. Palencia: Santa María la Real Fundación, 2013, pp 78-79.
} 
acreditamos que ele sempre foi marginalizado ${ }^{336}$, e poucos tiveram a coragem de abordá-lo, como fez Frei Hernando de Talavera, em sua obra Católica Impugnación, ao afirmar que algumas imagens religiosas são capazes sim de adquirir poderes milagrosos:

También ha este necio por inconveniente, que se diga que la imagen ríe y que llora y que la suda. Verdad es que puede haber y de hecho hay en esto muchas burlas y muchos sacadineros, pero es bien posible que ríe y llore y sude y hable, que es más, y se mueva y se absente presente, entendiéndolo todo esto sanamente, digo sanamente, porque las imágenes no ríen, ni lloran, ni hablan propiamente, como estas operaciones sean operaciones propias del hombre, mas hacen o padecen las imágenes actos y obras semejantes a estas operaciones y pasiones. Pues hace nuestro Señor aquesto cada que conviene, porque todo esto puede nuestro Señor Dios hacer y hace, cada que su providencia ve y sabe que conviene. ${ }^{337}$

Ou o Cardeal Gabriel Paleotti, um dos conselheiros do Concílio de Trento, quando define as imagens milagrosas, que foram capazes de interferir no mundo físico quando:

... lançam vivas lágrimas dos olhos, ou gotas de sangue verdadeiro, fazem algum movimento como se estivessem vivos, ou simplimente porque nelas [Deus ou seu protótipo] reconheceram a sua bondade divina. [nossa tradução ${ }^{338}$

Já em um primeiro momento, parece-nos correto $^{339}$ considerar que estas imagens ou objetos visuais não possuem poder em si e por si, como objetos materiais, mas adquirem tal poder quando o seu protótipo divino age através delas próprias. No entanto, após o potencial milagroso de uma imagem ser ativado por seu protótipo, aquele objeto transforma-se em sua essência e torna-se "prototípico".

Em nosso estudo, como vimos, foi um crucifixo que teria assumido o papel de imagem "prototípica", quando supostamente falou e sangrou. No entanto, este objeto teria sido destruído, e sua existência ficou registrada apenas nos processos da Inquisição, como nas declarações do pequeno Andresillo:

\footnotetext{
${ }^{336}$ Tomás de Aquino não produziu um texto sobre as imagens santas, mas sim sobre a imagem de Cristo, seu crucifixo. Também iremos apresentar mais à frente um excerto de Tomás, em que ele aborda o poder milagroso das imagens quando trata da ressuscitação de Cristo. Ver também capítulo 2, pp. 39-40.

${ }^{337}$ TALAVERA, Frey Hernando de. Católica Impugnación, Barcelona: Juan Flores, 1961. pp. 189-190.

338 “... gittare vive lagrime dagli occhi o gocciole di sangue, overo fare qualche movimento della persona, come fossero vive, o pure perché in esse si sarà evidentemente riconosciuta la bontà divina." PALEOTTI, Gabriel. Discorso intorno alle imagini sacre et profane. Livro I, cap. XVI, 1582. Ver capítulo 2, pp. 36-37.

${ }^{339}$ Não conseguimos questionar o entendimento dos fíeis acerca destas imagens, se eles consideravam as imagens em si (objeto material) milagrosas e santas, ou se eles acreditavam que seus protótipos divinos agiam por meio delas.
} 
Los dicho sus padres le [imagen de Cristo] ponían unos alfileres en las dichas espinas y cuando le azotaban decía el Cristo que por qué le azotaban y que respondían sus padres que aunque le pesase y amargase le habían de $\operatorname{azotar}^{340}$

Como desconhecemos tal objeto milagroso, e como por meio das fontes escritas não pudemos definir exatamente como seria esse crucifixo, só podemos inferir sua aparência, que de acordo com as pinturas, parece-nos ser um Christus Patiens ${ }^{341}$, um crucifixo com um Cristo pregado à cruz, coroado, com suas chagas e sem vida (Figura 46).
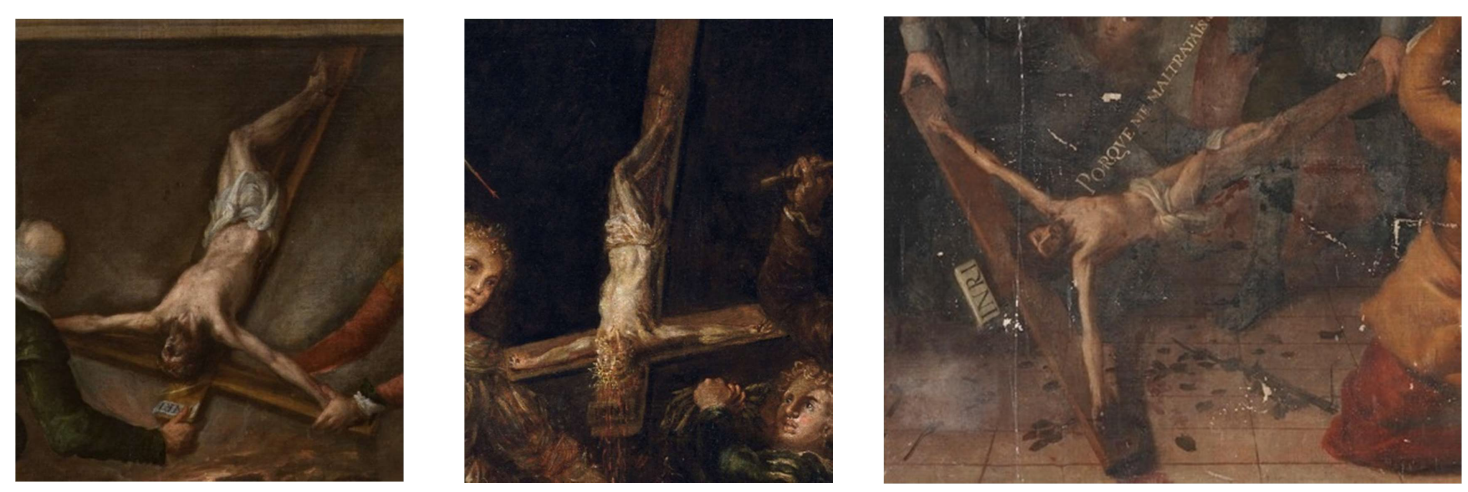

Figura 46 - Detalhes das Figuras 1, 2 e 3

Mas o importante é ressaltar que, na história do cristianismo, existiram inúmeros relatos de crucifixos milagrosos. Os primeiros testemunhos sobre manifestações místicas de crucifixos no Ocidente datam do século $\mathrm{X}$, e segundo Sasterre "la aniamción milagrosa de la mayor imagen del cristianismo está próxima a la aparición de su culto" ${ }^{342}$. As manifestações da presença de Cristo em suas efígies são mais abundantes que as manifestações marianas e a de outros santos, provavelmente por seu estatuto de sua maior sacralidade ${ }^{343}$ dentro do ritual, como também por sua numerosa presença em ambientes privados e públicos. Quanto à tipologia milagrosa resultante de ataques, o sangrar ou chorar, por vezes para aqueles que presenciavam ou

\footnotetext{
${ }^{340}$ AHN Inq. Leg. 140.Caixa 2. Proceso contra Miguel Rodriguez, fol 43r-44r.

${ }^{341}$ SÁNCHEZ MILLÁN, Rafael. Arbol, vid y leño de la tentacíon: Cristo crucificado y el protagonismo de la cruz. IMAGO: Revista de Emblemática y Cultura Visual, Valencia, 2011, nº 3, pp. 7-24.

${ }^{342}$ SANSTERRE, Jean-Marie. La imagen activada por su prototipo celestial: milagros occidentales anteriores a mediados del siglo XIII, 2013, p 82.

343 “....adoramos com uma adoração de latria a imagen de Cristo, que é o verdadeiro Deus, não por causa da imagen em si, mas por causa da coisa de que ela é a imagen...” AQUINO, Tomás. Suma Teológica. Parte III. Questão 25. Art. 3. Apud: LICHTENSTEIN, Jacqueline. A pintura: textos essenciais. Vol. 2: A teologia da imagem e o estauto da pintura, 2008, p. 55.
} 
ouviam dizer de sua ocorrência, funcionava como antonomásia do evento histórico, da paixão de Cristo $^{344}$.

Como já apontamos, os crucifixos milagrosos tiveram admirável presença nas crenças devocionais espanholas, o que pode ser apreendido por meio da leitura de obras como a escrita pelo inquisidor dominicano Jaime Juan de Bleda, Cuatrocientos milagros, y muchas alabanças de la santa Cruz, impressa em $1600 .^{345}$

Por conseguinte, definimos que o Cristo crucificado que foi figurado nas pinturas da capela do convento do Cristo da Paciência, de Madri, pertence àquela categoria de imagens que seriam capazes de exercer um poder milagroso, atuando no plano terrestre em prol da cristandade - nas palavras de Didi-Hubeman, prototípicas.

\section{A meta-imagem: a representação da imagem sagrada}

Um dos aspectos que merecem destaque neste nosso estudo é a representação pictórica, nas imagens em análise, da imagem sagrada que é o crucifixo. Este é um objeto religioso que representa tridimensionalmente um protótipo divino, o momentochave da vida da personagem mais importante da fé cristã, o Cristo pregado à Cruz. Para melhor compreendermos esse aspecto do nosso objeto de estudo - o fato de se enquadrar dentre as pinturas que figuram não o crucificado, mas sim um crucifixo -, iremos apresentar uma série de exemplos de pinturas que retratam imagens religiosas, ou seja, não os seus protótipos, mas sim suas efígies.

Encontramos diversas pinturas espanholas que representam imagens e objetos religiosos, produzidas no período em que a historiografia denominou como barroco, objetos estes que foram considerados milagrosos, cujas famas ultrapassaram seus

\footnotetext{
344 SANSTERRE, Jean-Marie. La imagen activada por su prototipo celestial: milagros occidentales anteriores a mediados del siglo XIII, 2013, p. 94.

${ }^{345}$ Ver: SÁEZ, Adrián J. Los Cuatrocientos milagros de la Cruz: ¿Libro de cabecera de Calderón?, 2013, pp 103-118.
} 
espaços de origem. Este é o caso das inúmeras pinturas que figuram a imagem escultórica do Cristo de Burgos (Figura 47) ${ }^{346}$.

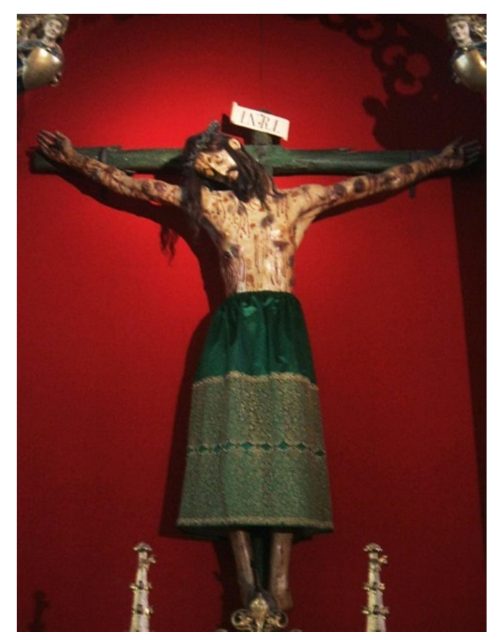

Figura 47 - Cristo de Burgos, Catedral de Santa Maria de Burgos: capela do Santíssimo Cristo de Burgos.

${ }^{346}$ Sobre o milagroso Cristo de Burgos, ver capítulo 2, pp. 42-44. 


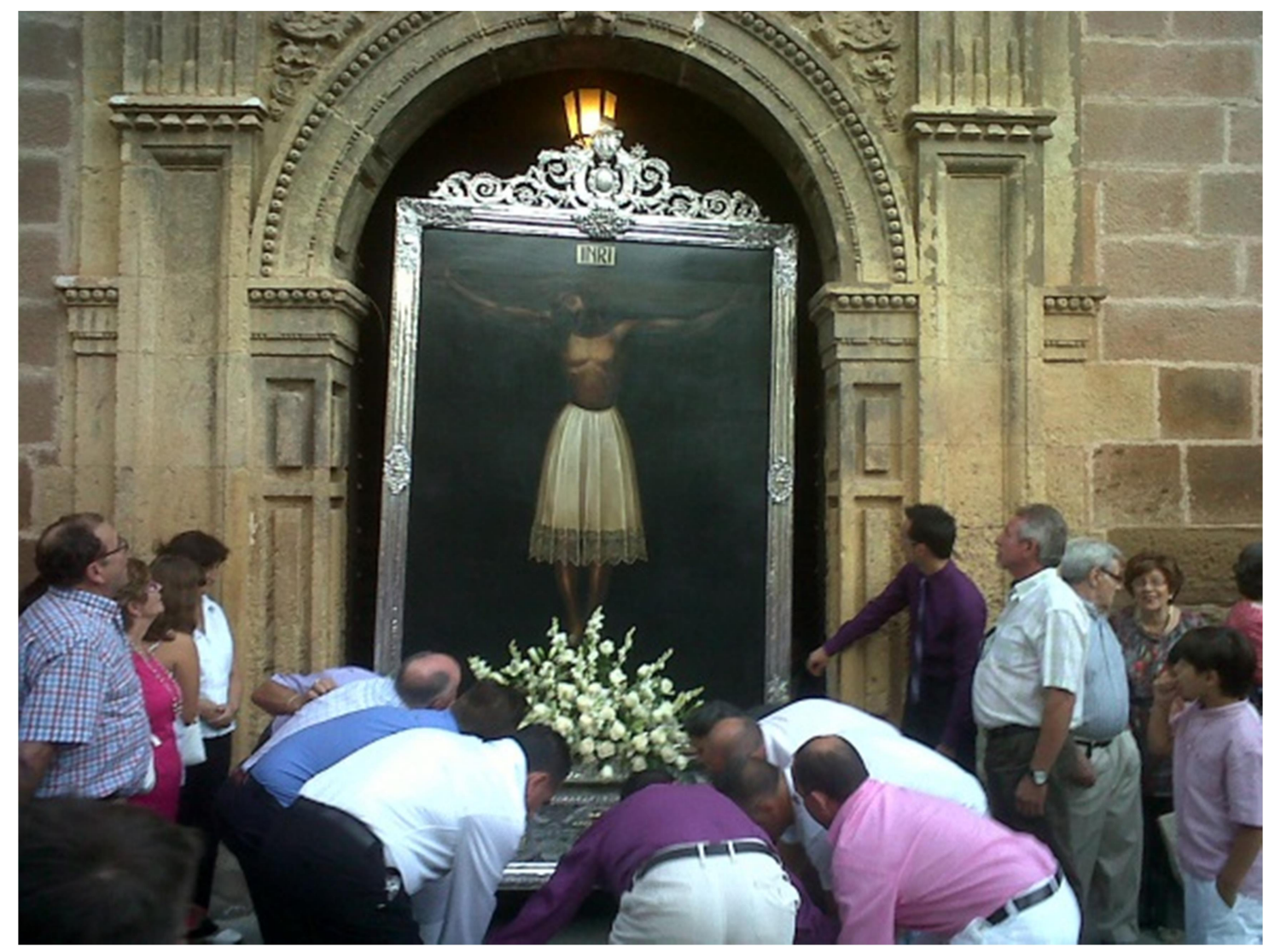

Figura 48 - Santíssimo Cristo de Burgos, séc. XVII, óleo sobre tela, Jacinto Aguiano Ibarra - Santuário de Cabra do Santo Cristo de Jaen

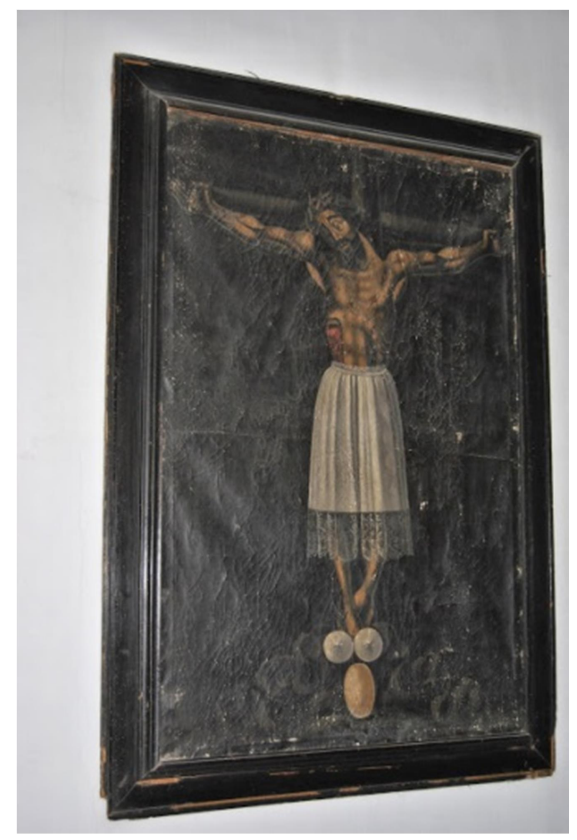

Figura 49 - Santíssimo Cristo de Burgos, sec. XVII, óleo sobre tela, Mateo Cerezo el viejo, Monastério de São Joaquim e Santa Ana de Valladoli. 
A Figura 48 é de uma pintura que figura o Cristo de Burgos, encomendada no início do século XVII ao pintor Jacinto Aguiano Ibarra pelo cavaleiro da ordem de Santiago e devoto do Cristo milagroso, Dom Jerónimo Sanvítores ${ }^{347}$. Hoje esta obra pertence ao Santuário de Cabra do Santo Cristo de Jaen, e todo dia 15 de agosto sai às ruas em procissão. Podemos ainda apresentar outra pintura, também do século XVII, com a mesma temática, produzida pelo pintor Mateo Cerezo, el viejo, um especialista nesta temática, para o monastério de São Joaquim e Santa Ana de Valadoli (Figura 49). Só deste mestre temos notícias de mais cinco outras pinturas que figuram o Cristo de Burgos: do convento da Vitória de Serradilla em Cáceres, da catedral de Santo Domingos de la Calzada, em La Rioja; dos comendadores de Santiago de Madri; da igreja de Santa Maria de Oxirondo de Vergara em Guipúzcoa; da basílica de Nossa Senhora dos Milagres de Ágreda em Sória, e da igreja da Vitória de Cascante em Navarra $^{348}$.

Em nossa dissertação, no capítulo introdutório já elaboramos um breve apontamento a respeito de pinturas apresentam uma retórica visual do "trampontojo a lo divino", termo empregado pelo historiador da arte Alfonso Perez Sánchez ${ }^{349}$. E para outro historiador da arte, Alfonso Rodriguez Ceballos, estas as pinturas figuraram imagens de culto como elas são cultuadas, em altares ou retábulos, com seus adornos (trajes, joias, velas, vasos), e o artista deveria esmerar-se tecnicamente para levar o espectador fiel a "acreditar" que estava diante da imagem de culto e não de uma representação desta. Porém, para além da representação, a historiadora Ángel Aterido observa que muitas destas pinturas que figuram objetos devocionais considerados

\footnotetext{
${ }^{347}$ GILA MEDINA, Lázaro. Arte e Historia del Cristo de Burgos o de Cabrilla en la Diocesis de GuadizBaza. Boletín del Centro de Estudios Pedro Suárez. Guadix: Instituto de Estudios "Pedro Suárez", 2003, p. 26.

${ }^{348}$ SÁNCHEZ RIVERA, Jesús Ángel. Mateo Cerezo "el Joven" y su padre en el convento santiaguista de Madrid: nuevas pinturas e hipótesis sobre su presencia. In: XIX SIMPOSIOIM SAN LORENZO DEL ESCORIAL: LA CLAUSURA FEMININA EN EL MUNDO HISPÁNICO. Escorial:2011. Simposium... Escorial: Instituto Escurialense de Investigaciones Históricas y Artísticas, 2011, pp. 10301031.

${ }^{349}$ Não tivemos acesso ao texto que Alfonso Pérez elabora a questão do trampontojo a lo divino, mas apenas as considerações de RODRIGUEZ G. DE CEBALLOS, Alfonso. "Trampantojos a lo divino": iconos pintados de cristo y de la virgen a partir de imágenes de culto en América meridional, 2001, p. 24. Porém em outra obra, quando Sánchez trata da pintura do Crucificado de Zurbarán, ele apenas diz que se trata de um efeito de busca imediata, realista e quase um trampantojo, e incentivado pela Igreja Católica. PÉREZ SÁNCHEZ, Alfonso E. Pintura Barroca en Enspaña : 1600-1750, 2010, p. 45 .
} 
milagrosos ultrapassaram o seu valor de representação e se tornaram um verdadeiro substituto daquela imagem original, adquirindo um valor icônico ${ }^{350}$.

Para além dessa tipologia representativa, podemos apresentar outras formas de figurar bidimensionalmente as imagens religiosas, sejam elas pinturas ou esculturas. Podemos apontar as várias pinturas em que santos e pessoas pias são figurados em oração diante de uma imagem religiosa como um crucifixo, como no óleo sobre tela de Bartolomé Román, San Pedro Celestino, Papa [P03346] do Museu do Prado, datada do inicio do século XVII (Figura 50). Como podemos ver, nesta pintura o artista, ao figurar o crucifixo, não pretende iludir o espectador ou mesmo figurar uma imagem devocional, mas sim compor uma cena narrativa.

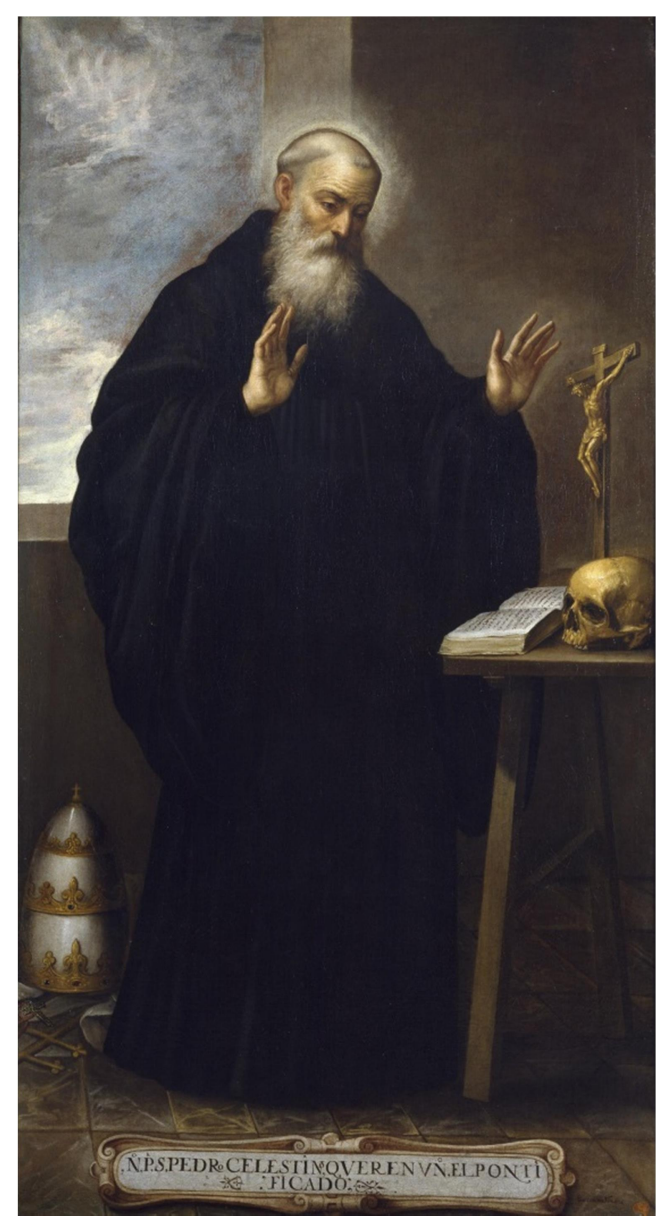

Figura 50 - San Pedro Celestino, papa, sec. XVII, óleo sobre tela, $208 \mathrm{~cm} \mathrm{x} 110 \mathrm{~cm}$, Bartolomé Román, Museu do Prado [P03346].

\footnotetext{
${ }^{350}$ ATERIDO, Ángel. Las relaciones entre escultura y pintura en el Madrid del siglo XVII. El caso de las capillas dedicadas a la Pasión. In: CARLOS VARONA, María Cruz de, CIVIL, Pierre, ESPESO PEREDA, Felipe, VICENT-CASSY, Cécile (coord.). La Imagen religiosa en la monarquía hispánica: usos y espacios. Madrid: Casa de Velázquez, 2008, p. 151.
} 
Ou seja, nesta obra o crucifixo foi figurado como objeto visual religioso que participa do momento de oração do santo. Do mesmo modo, podemos citar outra obra do Museu do Prado, o óleo sobre tela San Jerónimo [P00987] de Murillo, pintado em 1650, nele o crucifixo representado participa do momento de meditação do santo (Figura 51).

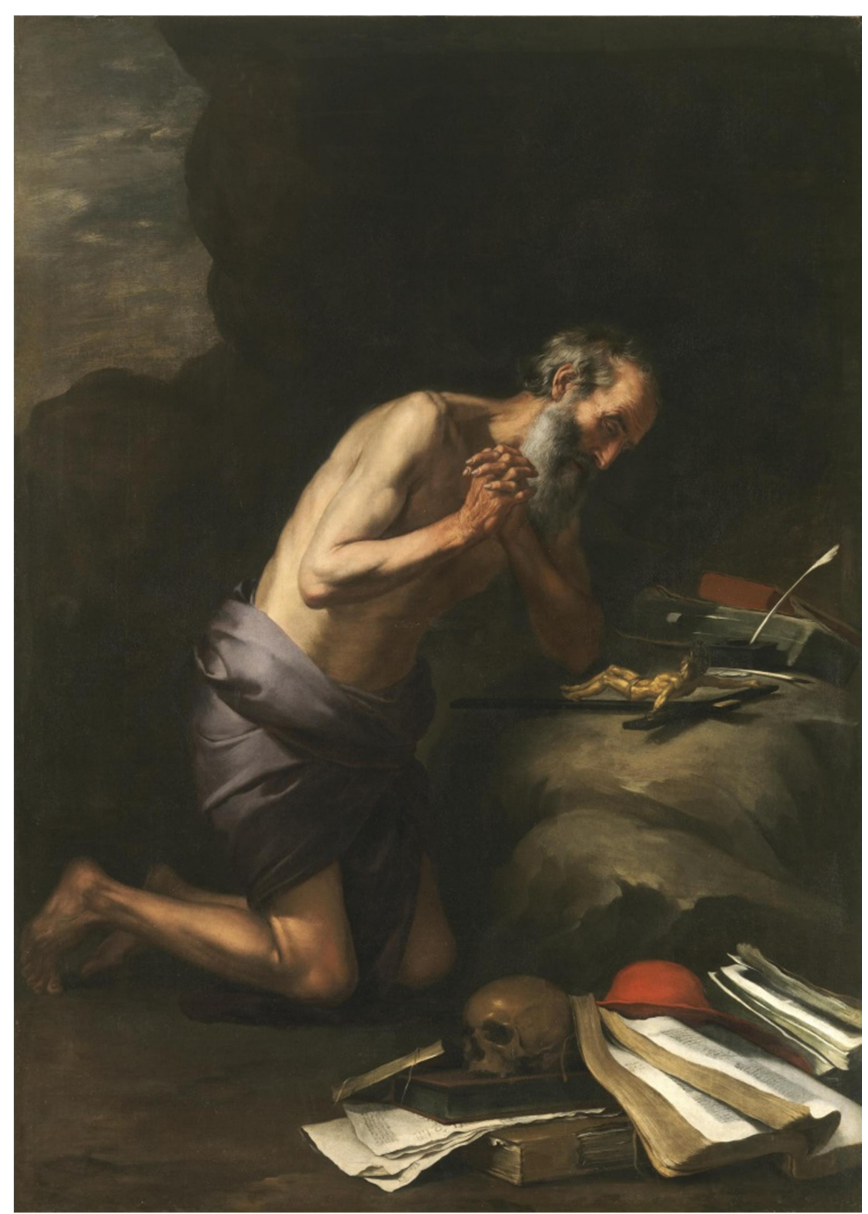

Figura 51 - San Jerónimo c. 1650, óleo sobre tela, $187 \mathrm{~cm}$ x $133 \mathrm{~cm}$, Bartolomé Esteban Murillo, Museu do Prado [P00987].

Outra pintura com as mesmas características figurativas é um retrato de uma fidalga que foi monja franciscana, o óleo sobre tela de Velásquez, La venerable madre Jerónima de la Fuente (Figura 52), produzido em 1620. Neste caso, o crucifixo não está participando do momento de oração, mas sim "fuertemente sostenido, casi como un 
arma..."351, mas mantendo seu caráter de objeto visual religioso inserido na composição do retrato da monja.

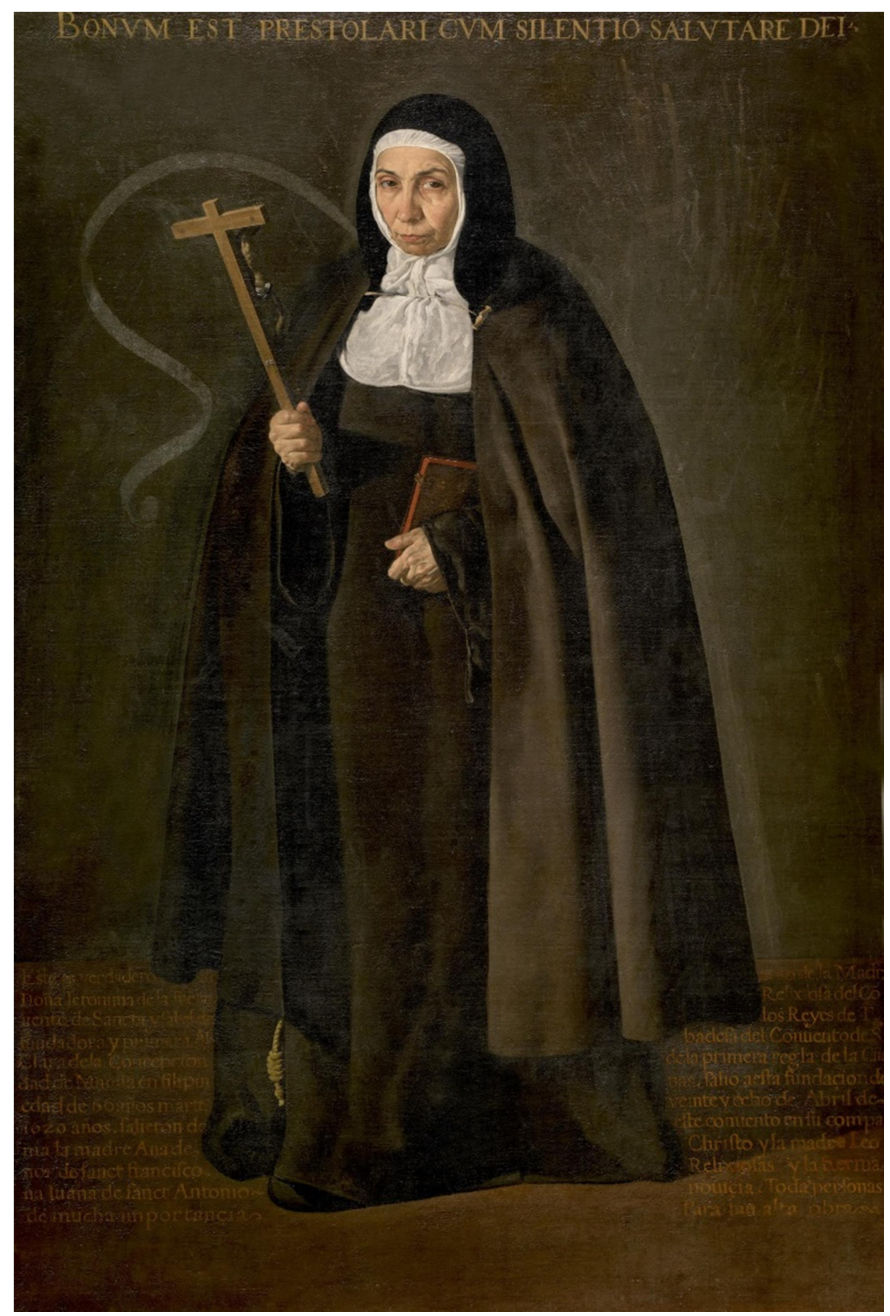

Figura 52 - La venerable madre Jerónima de la Fuente, 1620, óleo sobre tela, $160 \mathrm{~cm}$ x $110 \mathrm{~cm}$, Diego Rodríguez de Silva y Velásquez, Museu do Prado [P02873].

Podemos também apresentar outras pinturas de caráter narrativo de outras circunstâncias, como a pintura de um mestre anônimo, da região de Flandres, a Cena dos iconoclastas contra a adoração dos reis magos, que pertence ao Museu da Chartreuse, em Douai, na França (Figura 53). Esta pintura, afora o tema da iconoclastia, é um exemplo de imagem que figura outra pintura religiosa: uma representação da adoração dos Reis Magos. Vemos que a intenção não é figurar uma

351 MUSEU DO PRADO. Coleccion. https://www.museodelprado.es/coleccion/obra-de-arte/lavenerable-madre-jeronima-de-la-fuente/7fdeb84a-a3ba-42c9-a4d1-ebca272878ce?searchid $=96670726$ 9fb5-1fbd-7d26-330f2ce0964c. Acesso em 15/12/2015 
cena da adoração dos reis Magos, mas sim a sua representação como um dos elementos do contexto narrativo em que três pessoas estariam na iminência de destruir tal tela ${ }^{352}$.

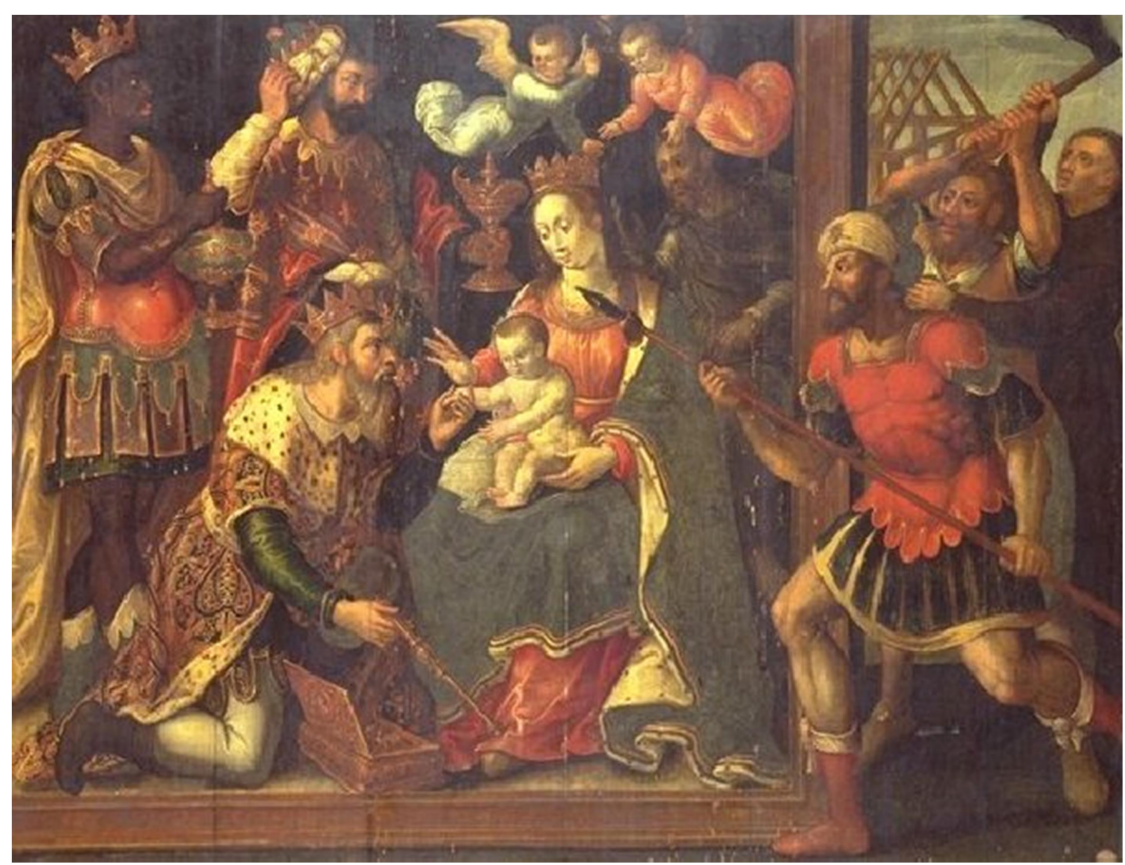

Figura 53 - Cena dos iconoclastas contra a adoração dos reis magos, sec. XVI, óleo sobre madeira, Museu da Chartreuse [ $\mathrm{n}^{\circ}$ do inventário: 1598].

Outro exemplo de ataque iconoclasta, que já apresentamos aqui, é a pintura Cristo de Medinaceli arrastrado por las calles de Mequinez, de Juan de Valdes Leal, finalizada em 1681 (Figura 7). Nesta obra, da mesma forma que na anterior, é uma escultura de Cristo que está sendo arrastada e açoitada por um grupo de muçulmanos, e não o próprio Cristo.

A pintura El milagro del Cristo del rescate (Figura 54), de Jerónimo Jacinto Espinosa, datada de 1623, figura uma imagem que adquiriu fama de milagrosa, pois teria sido roubada por muçulmanos que a lançaram ao mar; e que, mais tarde, teria

\footnotetext{
${ }^{352}$ Sobre esta pintura ver: STOICHITA, Victor I. L'instauration du tableau: Métapeinture à l'aube des tempes modernes, 1999; WIRTH, Jean. L'icocnoclasme aprés la Réforme. in: DUPEAUX, Cécile, JEZLER, Peter e WIRTH, Jean. Cataloque de l'exposition: Iconoclasme: vie et mort de l'image médievale. Paris: Somogy èdtions d'art: 2001; e MARTENS, Didier. Iconoclasmes et malentendus. Une imagen méconnue du Sacrièle de Cambron. Zeitschrift für Kunstgeschichte. Berlin: 2007.
} 
surgido milagrosamente no nas praias valencianas, no século XIII ${ }^{353}$. Apesar de esta obra ter a denominação de el milagro, quando o artista compôs a cena, ele não figurou o crucifixo agindo milagrosamente, mas sim em sua forma de objeto material. Apesar da nítida ambivalência figurativa, a historiografia reconhece que, nesta pintura, o que foi figurado não foi um Cristo na Cruz, mas sim um crucifixo afamado por seus poderes milagrosos. $^{354}$

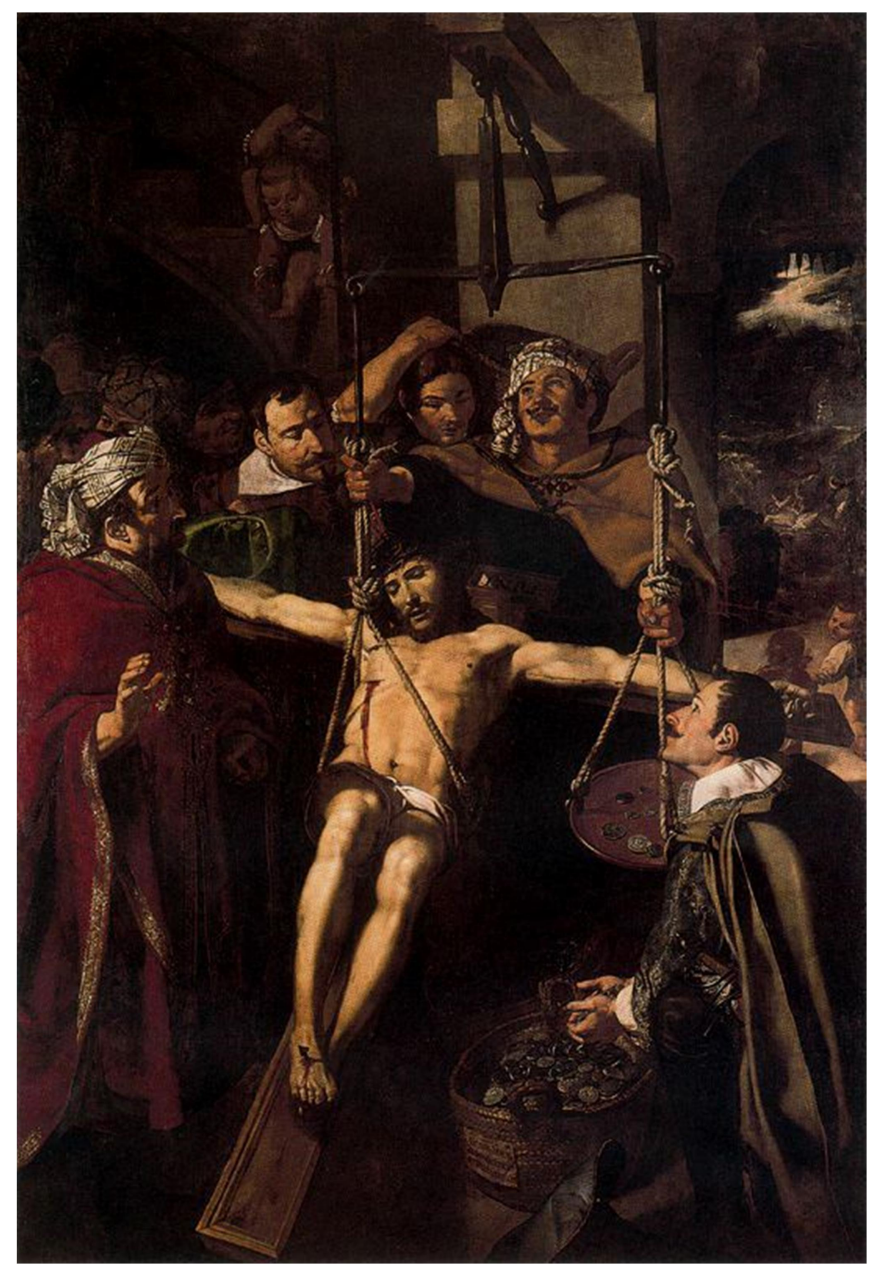

Figura 54 - El milagro del Cristo del rescate, c. 1623, óleo sobre tela, $243 \mathrm{~cm} \mathrm{x} 168$ $\mathrm{cm}$, Jerónimo Jacinto Espinosa, Coleção Privada, Valencia.

\footnotetext{
${ }^{353}$ VELANDIA ONOFRE, Darío. Hacia una teología de la imagen. Mística, oratória y pintura en la España del Siglo de Oro, 2014, pp. 292-295.

${ }^{354}$ VELANDIA ONOFRE, Darío. Hacia una teología de la imagen. Mística, oratória y pintura en la España del Siglo de Oro, 2014, pp. 292-295.
} 
Outra pintura narrativa que representa uma imagem religiosa é de Antonio Pereda, conhecida como San Domingo en Soriano (Figura 55), que figura a lenda de um milagre que teria ocorrido naquela cidade no século XVI, no convento dedicado a São Domingos $^{355}$. Mais uma vez, nossa intenção ao apresentar esta pintura é enfatizar que se trata da representação pictórica da pintura de São Domingos, e não do próprio santo.

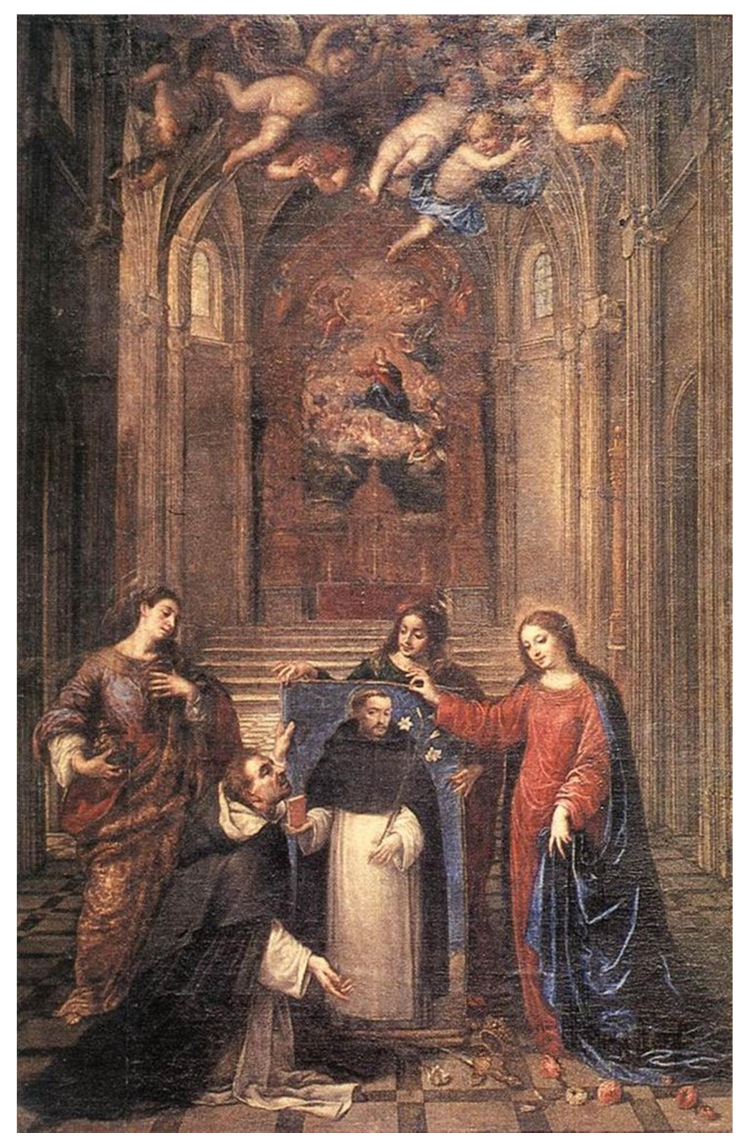

Figura 55 - San Domingo en Soriano, c. 1655, óleo sobre tela, $470 \mathrm{~cm}$ x $310 \mathrm{~cm}$, Antonio de Pereda, Museu Cerralbo [00056].

Podemos ainda apresentar outra pintura de Francisco Camilo, San Juan Evangelista y la virgen coronan a San Juan de Dios (Figura 56). Esta é mais uma pintura que narra um momento da vida de um santo ${ }^{356}$. Aqui, o que nos interessa é a

\footnotetext{
355 Sobre a lenda ver: www.dominicos.org/santo-domingo/iconografia/dominicana/santo-domingo-ensoriano

${ }^{356}$ Quando o santo estava na Igreja de Nossa Senhora de Granada, orando diante de um crucifixo, ele teve uma visão, de que São João Evangelista e a Virgem teriam saído de um quadro e lhe coroado com uma
} 
presença da pintura retabular ao fundo da cena. Notemos que a pintura exibe o momento de um milagre, que é ao mesmo tempo uma visão por meio da imagem, em que a pintura figurada exerce o milagre agindo no plano terrestre. Observamos, pois, que Camilo foi capaz de mostrar ao espectador não apenas a imagem do objeto visual, mas também o seu potencial milagroso.

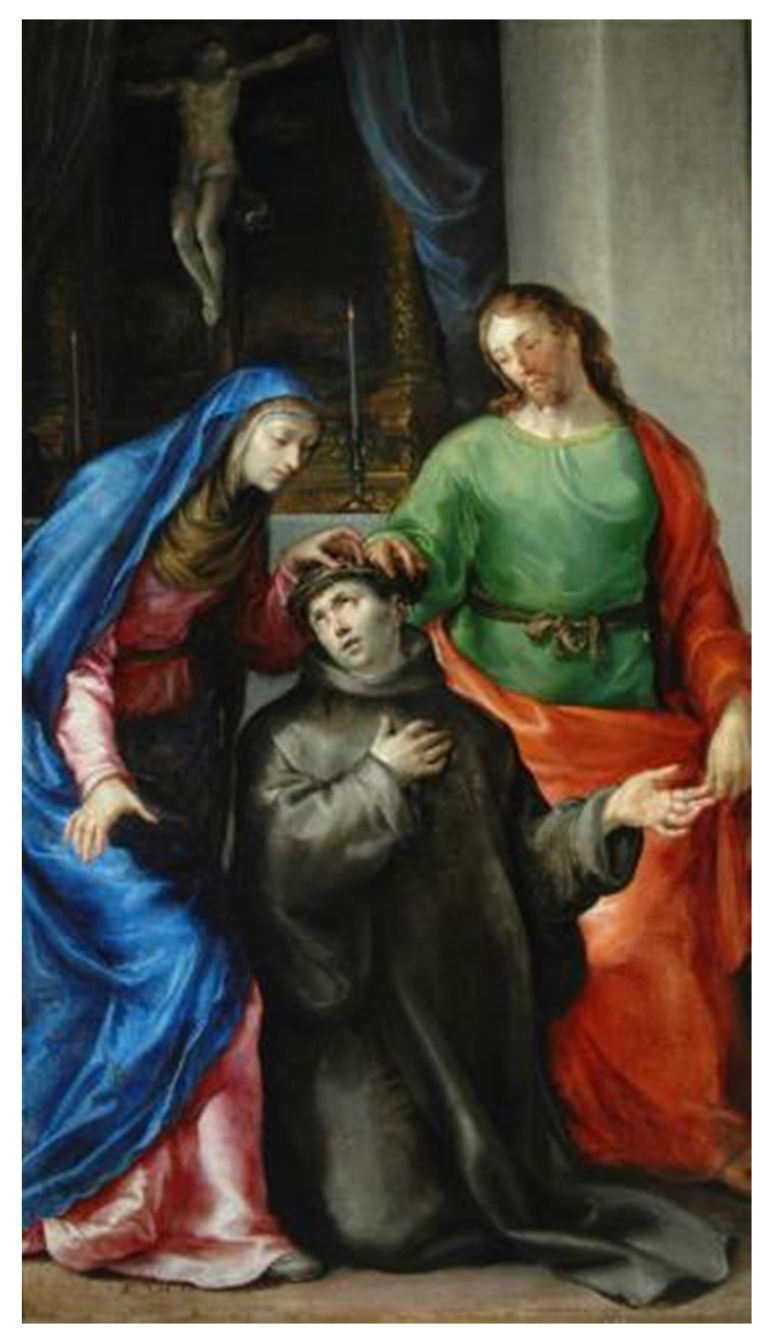

Figura 56 - San Juan Evangelista y la virgen coronan a San Juan de Dios, 1650, óleo sobre tela, Francisco Camilo, The Bowes Museum, Durham.

San Bernardo y la Virgen, de Alonso Cano, é mais um exemplo de um óleo sobre tela que figura uma imagem religiosa e sua ação milagrosa, a Lactatio Bernardi (Figura 57). Esta pintura pertence ao Museu do Prado, e provavelmente foi español, 1996, p. 63. 
encomendada para um retábulo dos Capuchinhos de Toledo ${ }^{357}$. A pintura de Cano representa o momento em que São Bernardo, ajoelhado em oração, contempla uma imagem da Virgem com o menino sobre um altar; ao que do seio direito da imagem figurada sai um jato de um líquido branco, que se supõe ser leite, que atinge a boca do santo. Constatamos então que, nesta pintura, o mestre espanhol também foi capaz de apresentar ao seu espectador a ação milagrosa da imagem.

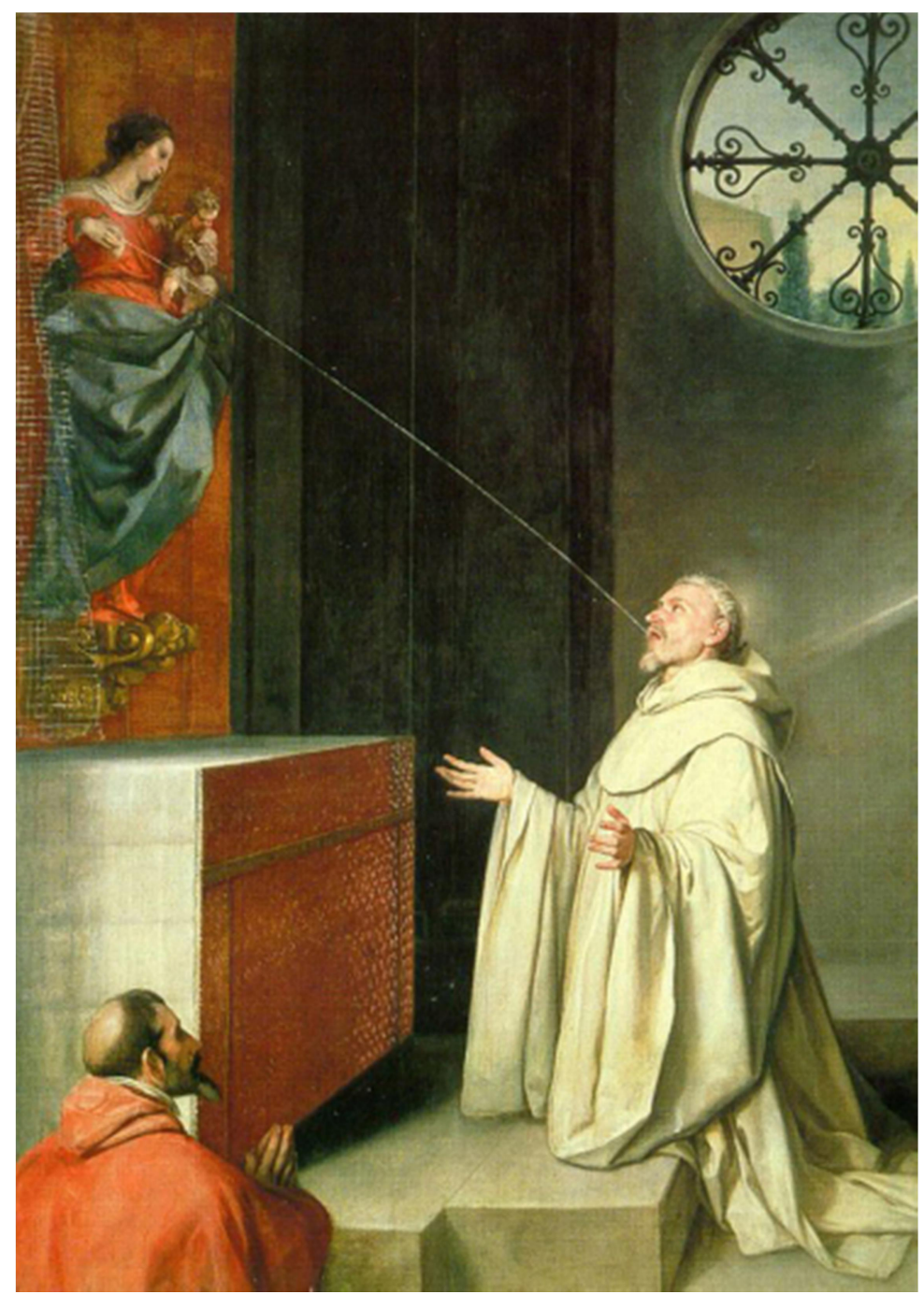

Figura 57 - San Bernardo y la Virgen, 1649-1652, óleo sobre tela, $267 \mathrm{~cm} \mathrm{x} 185 \mathrm{~cm}$, Alonso Cano, Museu do Prado [P03134].

Nossa intenção ao exibir esta série de pinturas foi apresentar as possibilidades representativas da figuração pictórica de imagens religiosas, ou seja, da figuração da

\footnotetext{
${ }^{357}$ MUSEU DO PRADO. Coleccion. www.museodelprado.es/coleccion/obra-de-arte/san-bernardo-y-lavirgen/25b83887-3b11-4a99-a9b1-3b3050733d6a. Acesso em 15/12/2015.
} 
representação de uma pessoa santa, e não desta em sua forma humana. Estamos abordando uma retórica visual de metalinguagem, em que os artistas, ao executarem suas pinturas, concebem imagens de esculturas, pinturas, e outros objetos visuais religiosos. Desta forma, apresentamos algumas pinturas em que a retórica da metalinguagem visual foi utilizada, seja como trampontojo a lo divino (mesmo que depois as pinturas tenham ultrapassado esse limite e se tornado elas próprias objetos de devoção), ou funcionado como um elemento que compõe visualmente uma narrativa. Por fim, com as duas últimas pinturas, a que representa o milagre das personagens que saem da pintura retabular e a da escultura da Virgem que verte leite, quisemos apresentar a estratégia pictórica de fazer visível a dupla realidade das imagens milagrosas, a qual denominamos como meta-imagem, que é a representação tanto do objeto visual como também de sua experiência mística, como as que foram figuradas nas pinturas do caso do Cristo da Paciência.

\section{O milagre da fala}

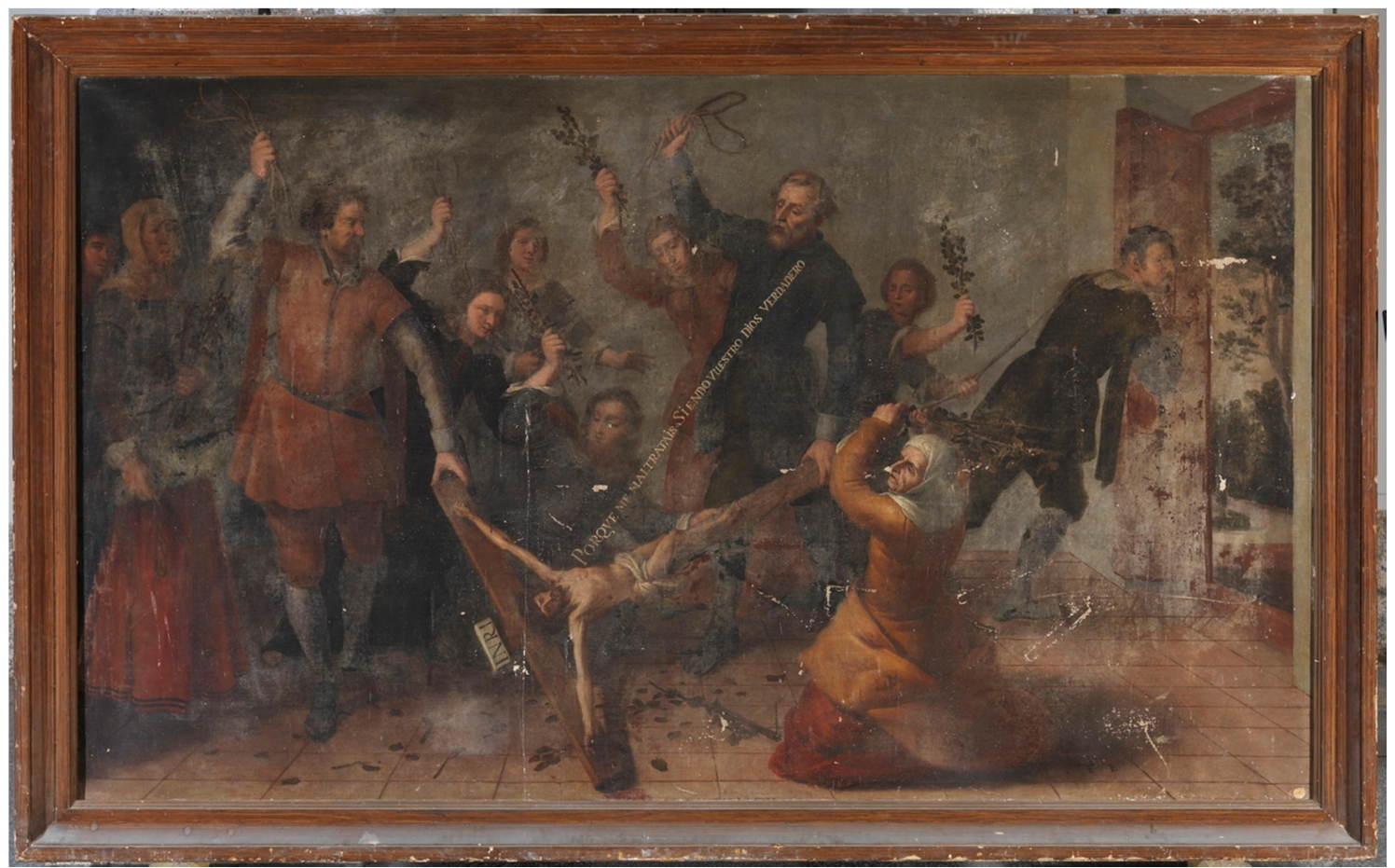

Figura 58 - Sacrilegio de unos judios: judios arrastando y azotan el crucifij, 16471651, óleo sobre tela, 171 x 296 cm, Francisco Fernadez, Museu do Prado [P03873]. 
"Porqve me maltratais siendo vuestro Dios verdadero" seriam as palavras que o crucifixo teria falado enquanto profanado pelos cristãos-novos portugueses acusados no caso do Cristo da Paciência (Figura 59).

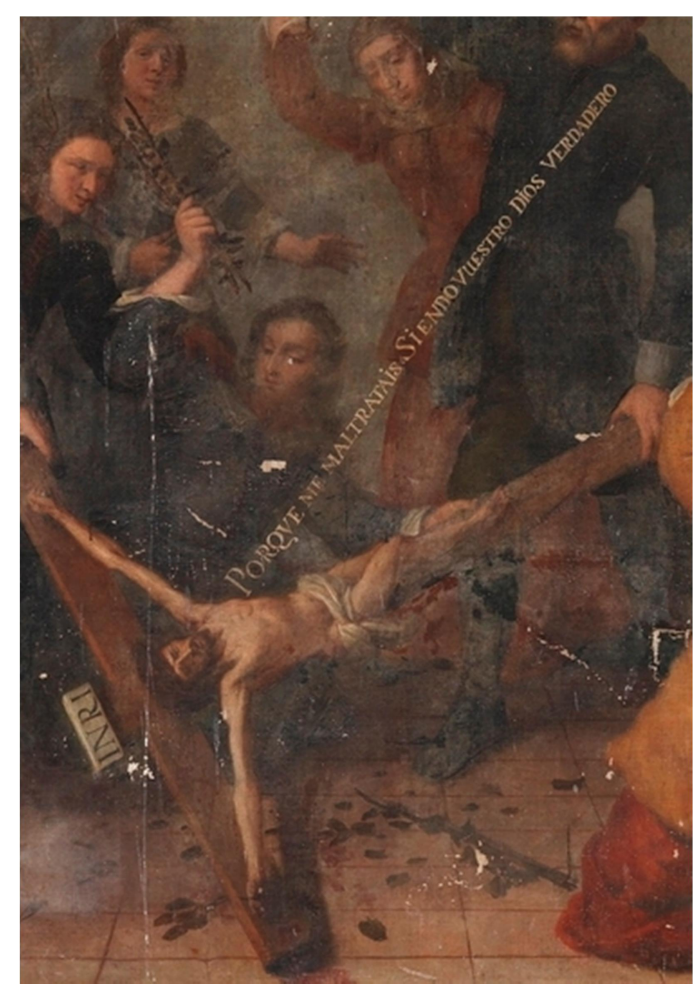

Figura 59 - Detalhe da Figura 58

Dentre os relatos sobre crucifixos que se expressam oralmente, o mais célebre de todos é sem dúvida o episódio do crucifixo de São Damião, quando São Francisco de Assis (1182-1226) entrou na Igreja de São Damião para rezar e: “... inaudito milagre! a imagem pintada de Cristo crucificado despregar os lábios e falar-lhe, chamando-o pelo próprio nome, disse: 'Francisco, vai e repara minha casa que, como vês, esta quase em ruína",358.

Outro santo de extrema importância para o cristianismo que teve uma experiência mística com um crucifixo falante foi São Tomás de Aquino. Em Nápoles, na capela de São Nicolau, o sacristão da igreja teria ouvido quando São Tomás, em oração diante do crucifixo, perguntou à imagem de Cristo se o que ele havia escrito

\footnotetext{
${ }^{358}$ CELANO, Tomás. Vida Segunda de São Francisco (1246-47). Braga: Editorial Franciscano, [2---], cap. IV.
} 
sobre os mistérios da fé estava correto e o crucifixo lhe respondeu: "Tu falaste bem de mim, Tomás. Qual será tua recompensa?" e Tomás teria respondido: "Nada mais que Tu, Senhor". 359

O Inquisidor Geral da Lombardia São Pedro Mártir também teve uma experiência mística com um crucifixo falante, quando diante dele orava. Tal milagre teria ocorrido no final do século XIII, quando o santo fora acusado falsamente de bruxaria e de receber mulheres em seus aposentos ${ }^{360}$. Após ser repreendido, o santo em oração, diante de um crucifixo, questiona a Cristo: "Que mal fiz senhor, para me ver como estou?" e o crucifixo teria lhe respondido: “E eu, Pedro? Que mal fiz?".361

Dois santos espanhóis que teriam presenciado a manifestação oral de objetos visuais religiosos foram São Tomás de Villanueva e São João da Cruz. O primeiro, em 1555, quando em Valência, teria tido sua morte anunciada por um crucifixo:

una noche estando en ejercicio, le habló aquél santo crucifijo, y porque fue acabando él de decir con mucha devoción entre otros salmos el de Miserere en latín, le dijo también aquella santa Imagen: 'Confortaos, tened buen ánimo y quieto, porque el día de la Natividad de mi santa madre vendréis a gozar de mi compañía y descansaréis ${ }^{362}$

No caso conhecido Milagre de Segóvia, que teria ocorrido em 1588, São João da Cruz, ao contemplar uma pintura de Cristo na cruz "se sentiu imediatamente transpassado de amor e transportado em êxtase, ${ }^{, 363}$, e decidiu levar a pintura para a igreja onde poderia ser contemplada por todos. Em outro momento, diante da imagem, agora na igreja, o Cristo pintado teria lhe dito: "Hermano Juan, pídeme lo que tú quieres, que voy a concedértelo por el servicio que me has hecho" e João teria respondido: "Señor, lo que

\footnotetext{
${ }^{359}$ Papa Bento XVI. Audiência geral (2/6/2010) http://w2.vatican.va/content/benedict-xvi/pt/audiences/2010/documents/hf ben-xvi_aud 20100602.html. Acesso em 01/12/2015.

${ }^{360}$ Ele teria recebido em seus aposentos conventuais a visita das Santas Mártires Inês, Cecília e Catarina

${ }^{361}$ Acesso em 16/12/2015: aciprensa.com/santos/santo.php?id=416

362 VILLANUEVA CUEVA, Carmen. El Crucificado, en la vida y escritos de Santo Tomás de Villanueva. SIMPOSIUM LOS CRUCIFICADOS, RELIGIOSIDAD, CONFRADÍAS Y ARTE, Escorial: 2010. Atas... Escorial: Instituto Escurialense de Investigaciones Históricas y Artísticas, 2010, p. 34.

${ }^{363}$ STOICHITA, Victor I. El ojo místico: Pintura y vision religiosa en el Siglo de Oro español, 1996, p. 59.
} 
quiero que me deis son los sufrimientos que tenga que soportar por vos y que yo sea despreciado y considerado como insignificante cosa" ${ }^{, 364}$.

Convém citarmos exemplos de pinturas que figuram imagens milagrosas que teriam se manifestado por meio da expressão oral para pessoas consideradas santas, a exemplo dos casos acima relatados. E cumpre ressaltar que, diferentemente dessas pinturas, a representação de Fernandez para o caso do Cristo da Paciência figura uma situação bem distinta, pois o crucifixo fala não a santos, a cristãos exemplares; pelo contrário, ele fala a seus algozes, em uma reencenação da própria Paixão.

O mestre Pedro Berruguete concebeu duas pinturas para o convento de São Tomás de Avila, em que crucifixos teriam adquirido a capacidade de expressar-se oralmente para dois santos da ordem. Uma das pinturas é um óleo sobre madeira que faz parte do retábulo da central da Igreja do convento dedicado a São Tomás, com imagens de episódios da vida do santo; dentre elas está uma que figura o momento em que um crucifixo fala (Figura 61). A cena apresenta quatro personagens, e o santo está ao centro, de joelhos, com a face voltada para um crucifixo sobre um altar. A imagem figurada parece ser a de um Cristo talhado em madeira, pregado a uma cruz e pintado; e perpendicular à sua face, o pintor concebeu uma frase, cuja reprodução não nos foi possível devido à baixa qualidade da imagem obtida. Assim, por meio desta frase é que Berruguete representou pictoricamente a manifestação do crucifixo.

${ }^{364}$ STOICHITA, Victor I. El ojo místico: Pintura y vision religiosa en el Siglo de Oro español, 1996, p. 59. 


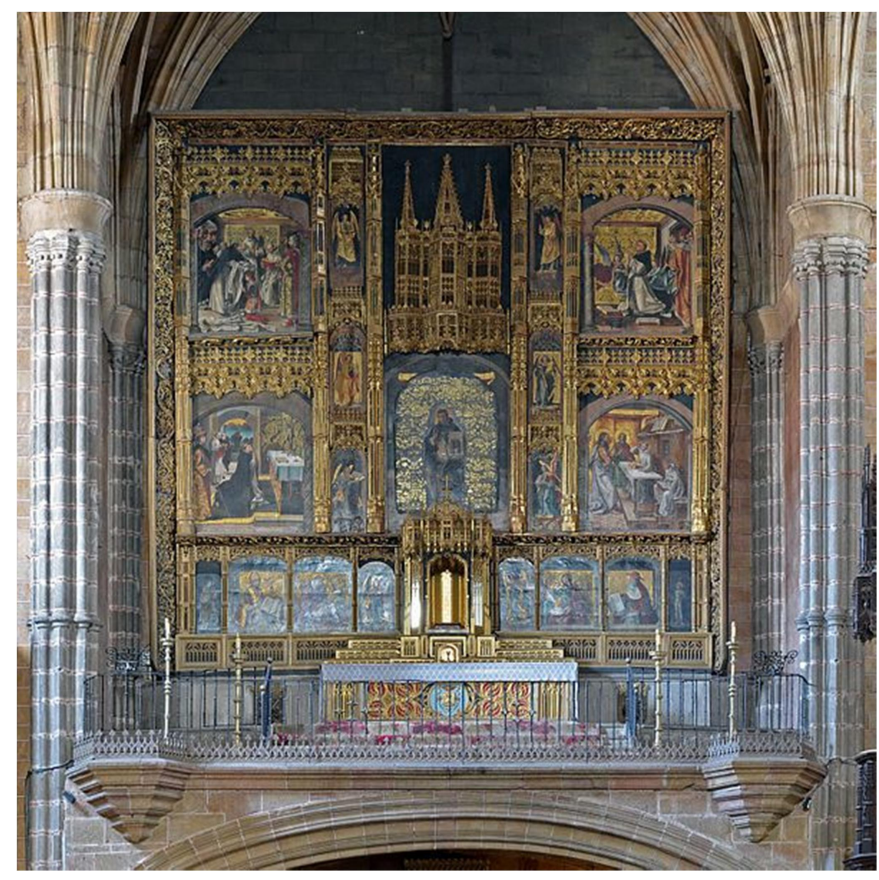

Figura 60 - Retábulo da Vida de São Tomas de Aquino, Igreja do real monastério de São Tomas de Avila.

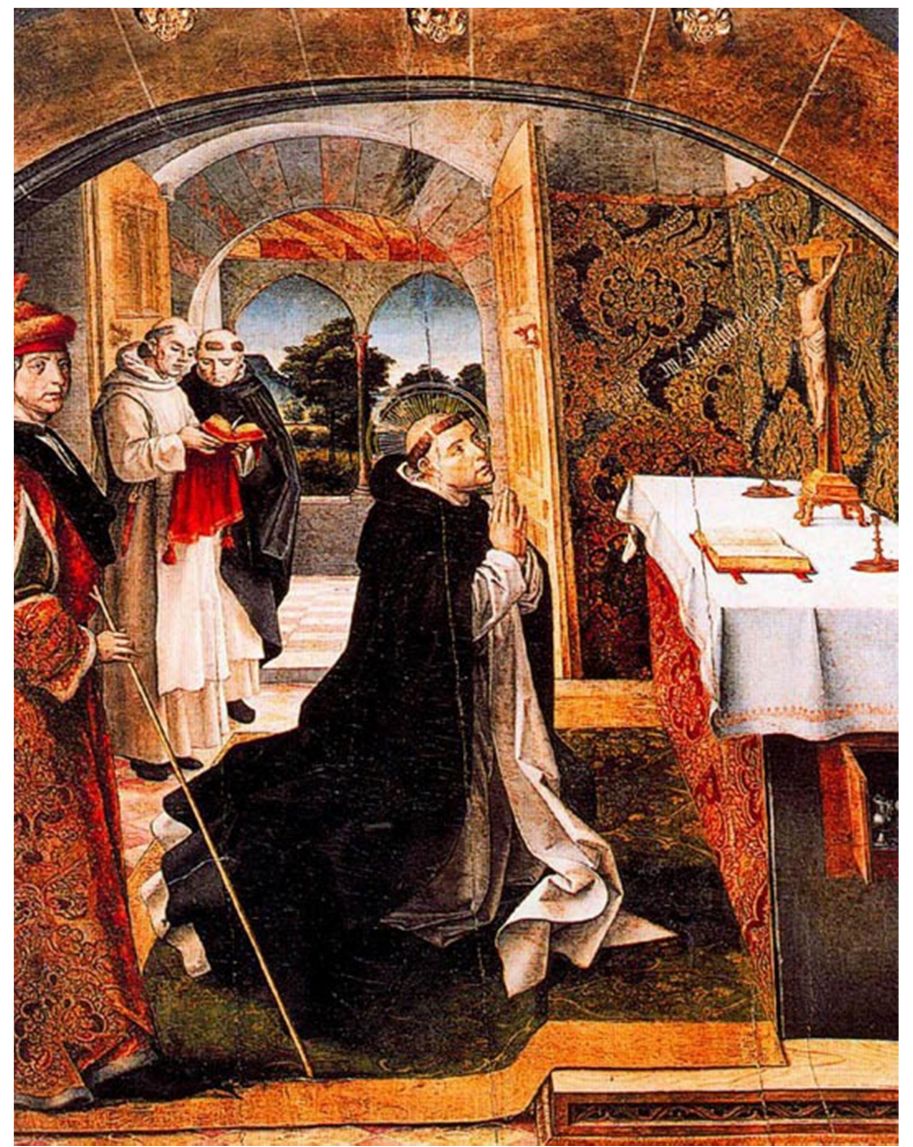

Figura 61 - Detalhe da Figura 60 
A outra imagem de Pedro Berruguete é um óleo sobre madeira que hoje pertence ao Museu do Prado, mas que havia sido encomendado no final do século XV para o claustro alto do mesmo mosteiro, onde junto com outras três pinturas compunha um retábulo dedicado a São Pedro Martir. A pintura em questão é conhecida como San Pedro Mártir em oración (Figura 62), e nela podemos ver que Berruguete figurou o santo ajoelhado diante de um altar com uma escultura de Cristo pregada à cruz. Próximo ao santo, que está com sua boca aberta, ele figurou as seguintes palavras: "Pego domine in te innocens patioz" e, próximo ao crucifixo, vemos, de cabeça para baixo: "Et ego petre quid feci". Deste modo, Berruguete, ao figurar estas duas frases próximas ao santo e à imagem religiosa, compôs pictoricamente a manifestação milagrosa do crucifixo.

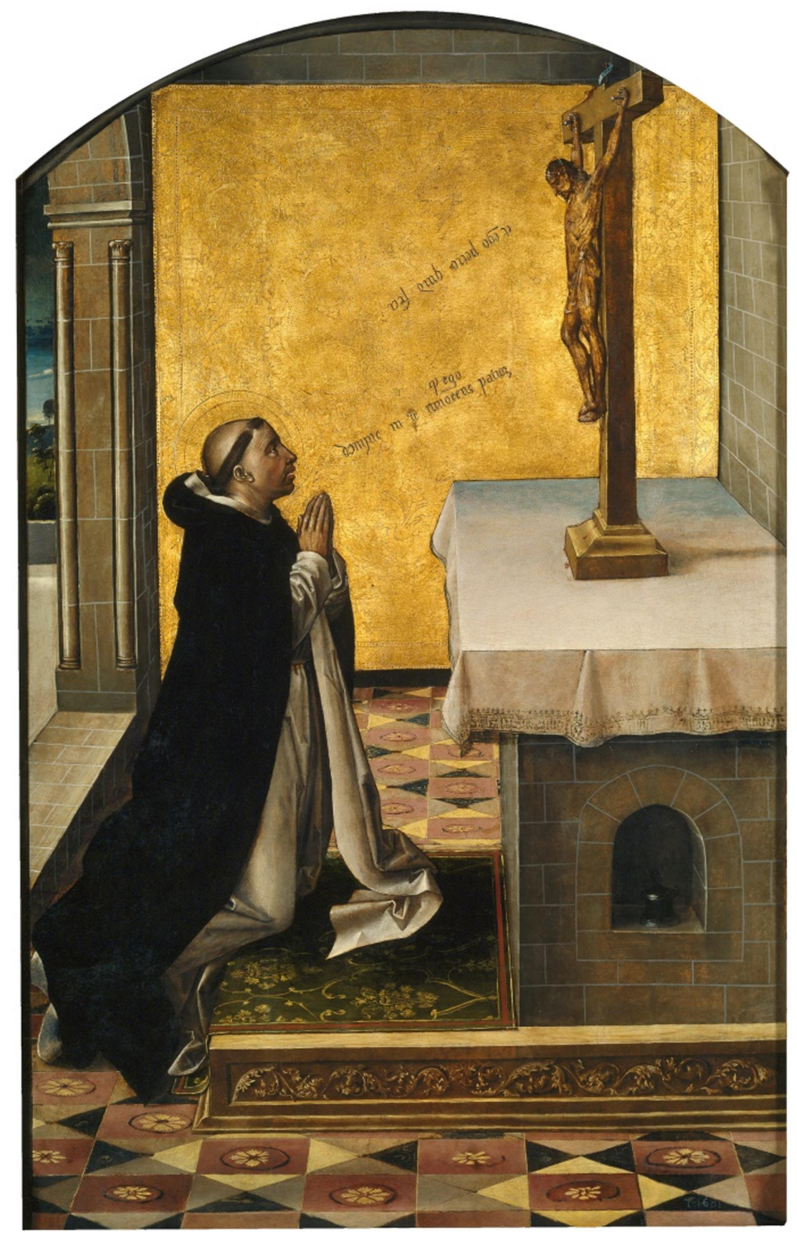

Figura 62 - San Pedro Mártir en oración, sec. XV, óleo sobre madera, 133 cm x $86 \mathrm{~cm}$, Pedro Berruguete, Museu do Prado [P00612].

No século XVII, Bartolomé Esteban Murillo pintou um óleo sobre tela que mostra o momento em que São Tomás de Villanueva teria recebido a notícia de sua 
morte por meio da manifestação oral de um crucifixo. A pintura é conhecida como Santo Tomás de Villanueva y el Crucifijo (Figura 63) e hoje está no Museu de Belas Artes de Sevilha. Murillo figurou São Tomás de joelhos e com olhar em direção a um crucifixo que está sobre um altar. Como que a ligar a face de Cristo à do santo, pintou as seguintes palavras: "In diei Navitatis matris mea veni es adme", compondo assim a manifestação milagrosa do crucifixo.

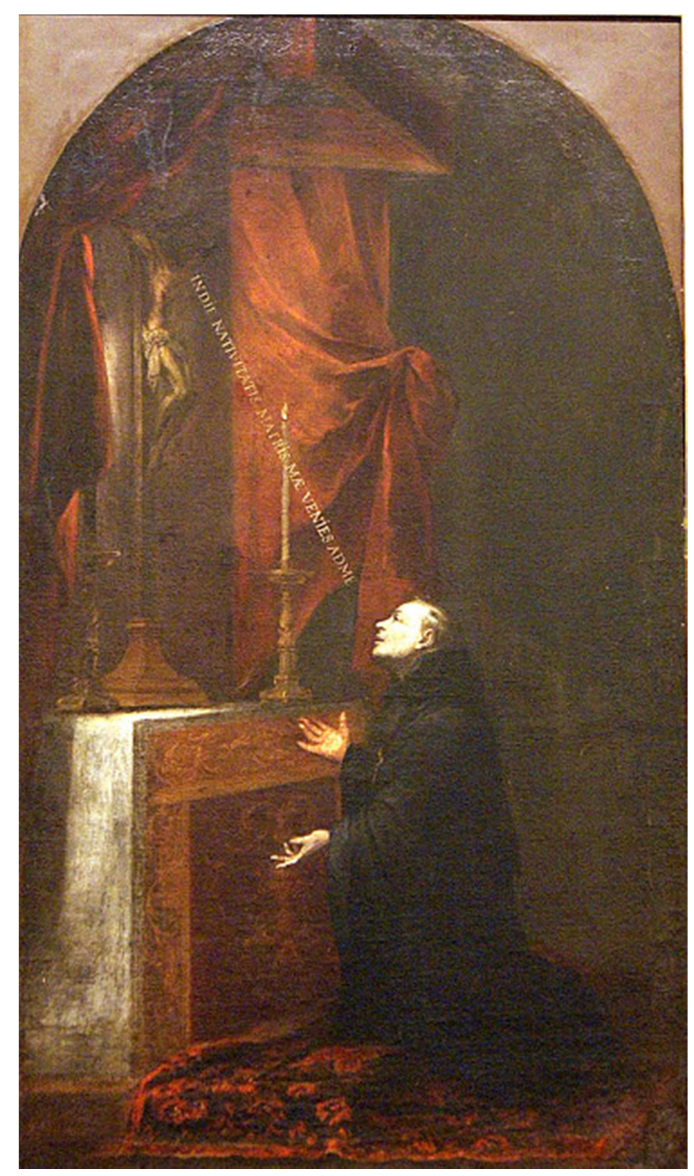

Figura 63 - San Tomas de Villanueva y el crucifijo, 1664-1670, óleo sobre tela, $130 \mathrm{~cm}$ x $75 \mathrm{~cm}$, Bartolomé Esteban Murillo, Museo de Bellas Artes de Sevilla [CE0126P].

Por fim, iremos apresentar aqui duas pinturas que figuram o Milagre de Segóvia. A primeira é um óleo sobre tela de Francisco Martinez produzida em 1625, hoje exposta no santuário da Virgem do Carmo, em Medina do Campo e conhecida como El milagro de Segovia. Aparición de Jesús de Nazareno (Figura 64). Nesta obra o artista concebeu duas cenas em perspectiva, sendo que na mais próxima ao espectador, à esquerda, ele compôs o milagre do diálogo místico entre o santo e a 
pintura de Cristo carregando a cruz. Como podemos notar, a opção para fazer visível a manifestação oral da pintura foi o uso da figuração dos textos: "quid vis pro laboriubus tuis, ioanes" e "domine, pati pro te et contemni" 365 , que ocupam o espaço entre as faces de Cristo e do santo.

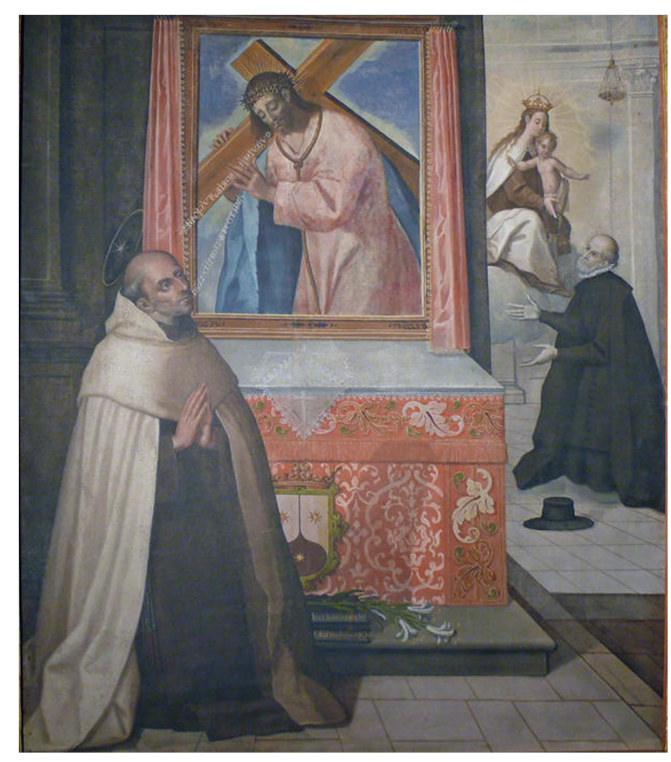

Figura 64 - El milagro de Segovia. Aparición de Jesús de Nazareno, 1625, óloeo sobre tela, Francisco Martínez, Santuário da Virgem do Carmo, em Medina do Campo.

E pela primeira vez em nossa dissertação podemos apresentar o trabalho de uma pintora, a portuguesa Josefa de Óbidos. Sua pintura em questão, um óleo sobre tela, está localizada na Santa Casa da Misericórdia de Figueiró dos Vinhos e foi pintada em 1673, tornando-se conhecida como Visão de São João da Cruz (Figura 65). A artista compõe a cena do santo diante da pintura de Cristo carregando a Cruz, e para representar o milagre que seria o diálogo estabelecido entre o santo e a pintura de Cristo, ela figura de forma circular algumas palavras saindo da boca do santo em direção ao Cristo pintado; e da representação da pintura, próximo à boca de Jesus, ela figura outra parte do dialogo.

\footnotetext{
365 delsolmedina.com/Medina2014/Museo/MuseoPieza\%20del\%20mes09-14.html. Acesso em $16 / 12 / 2015$
} 


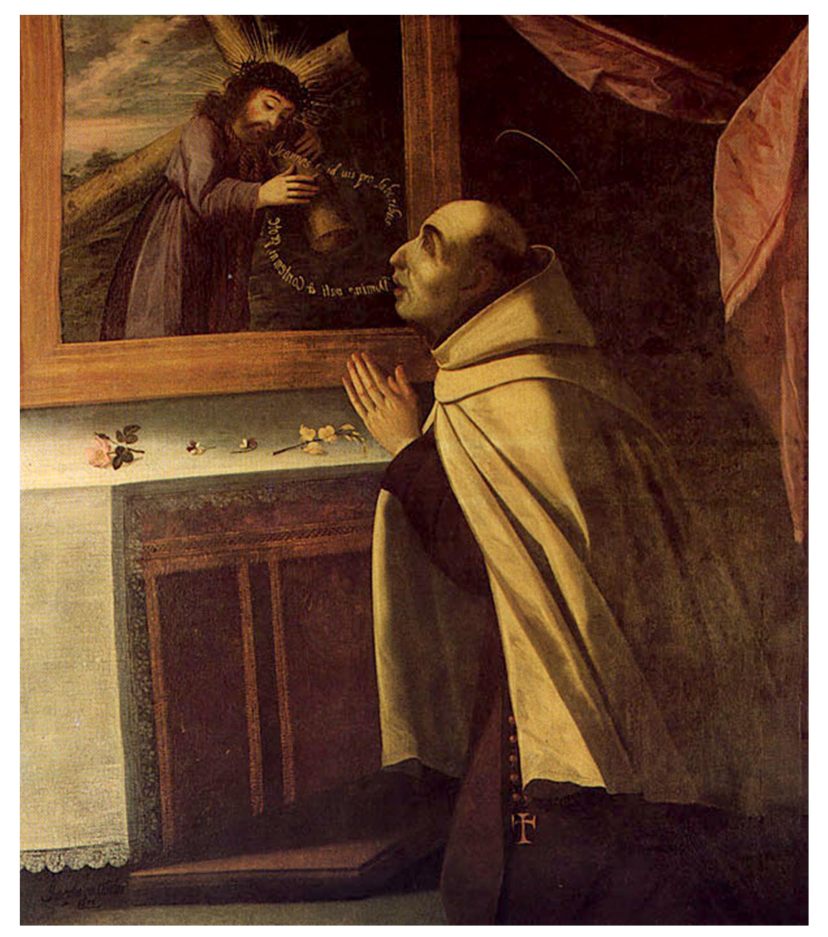

Figura 65 - São João da Cruz, c. 1673, óleo sobre tela, Josefa de Óbidos, Santa Casa da Misericórdia de Figueiró dos Vinhos.

Como podemos observar nessas pinturas apresentadas, todas partilham da mesma estratégia pictórica para compor o que denominamos de meta-imagem, a figuração da ação sobrenatural das imagens religiosas. Decerto que em cada obra encontramos particularidades, como a cor da letra, ou mesmo o movimento da frase na pintura de Josefa de Óbidos. E foi este o mesmo recurso que Francisco Fernandez utilizou para representar pictoricamente o suposto milagre da fala do crucifixo na pintura Sacrilegio de unos judios: judios arrastando y azotan el crucifijo, quando figurou as palavras: "Porqve me maltratais siendo vuestro Dios verdadero". Desta feita, o mestre madrileno fez uso de uma estratégia retórica habitualmente aplicada à representação visual da manifestação oral de objetos religiosos a santos (contemplando, meditando ou orando), em uma situação oposta, nomeadamente a resposta do objeto sagrado ao sacrilégio perpetrado por hereges. 


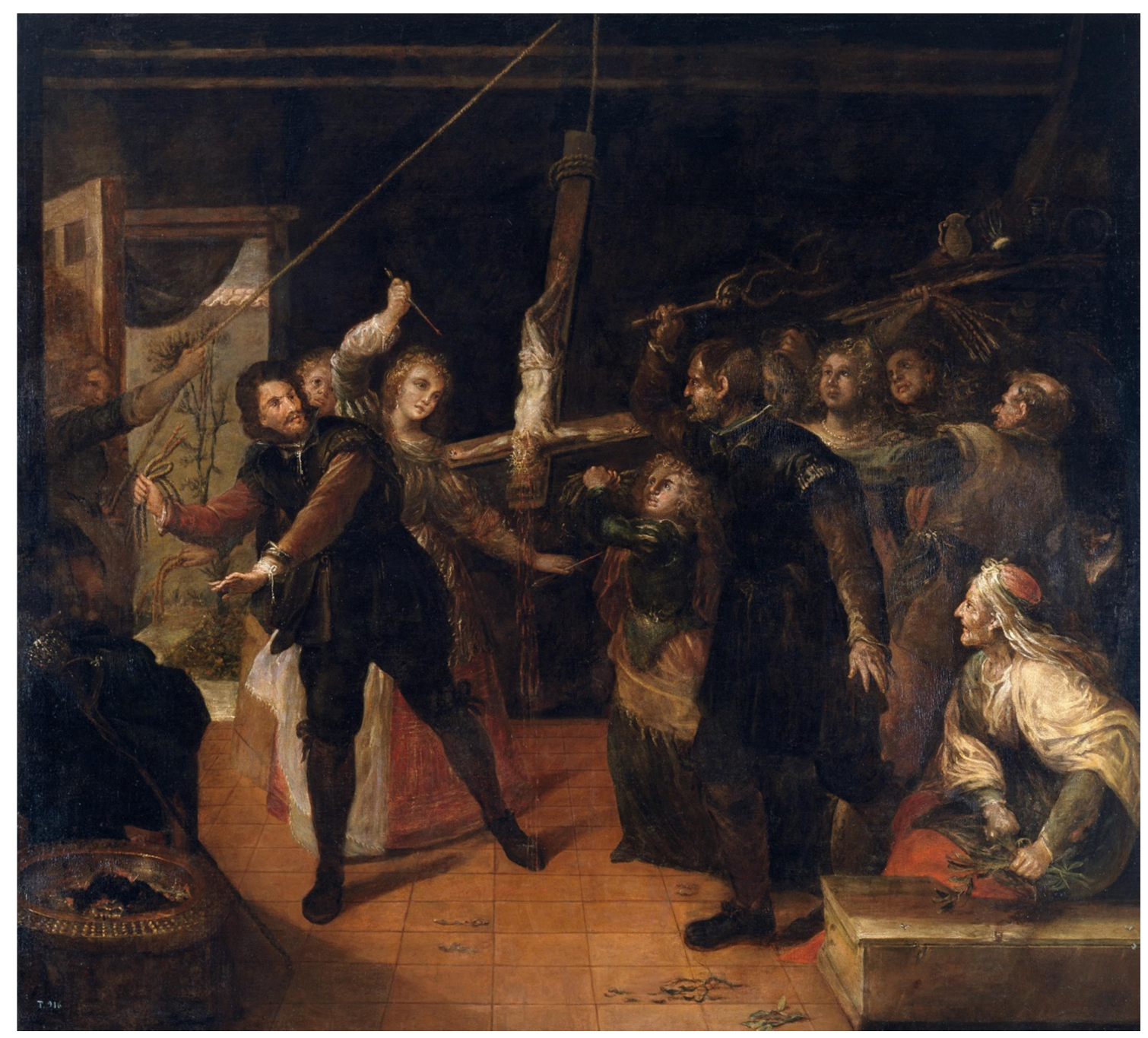

Figura 66 - Profanación de un crucifijo (Familia de herejes azotando un crucifijo), 1647-1651, óleo sobre tela, $207 \mathrm{~cm}$ x $230 \mathrm{~cm}$, Francisco Rizi, Museu do Prado [P03775].

Analisemos, pois, a figuração do milagre do sangue que teria sido vertido pelo crucifixo em meio ao seu açoitamento, concebida por Francisco Rizi. Em um cômodo escuro e com o chão de ladrilhos marrom-avermelhados, vemos, ao centro, o sangue que se derrama do crucifixo, que está pendurado de ponta-cabeça por uma corda. Notamos que a intenção de Rizi foi a de figurar a efígie de Cristo pregado à cruz e coroado, talhado em madeira e depois pintado. E da cabeça da imagem de Cristo escorre um líquido vermelho representando o sangue, que seria o fruto do milagre. 
Estamos diante de uma pintura que figura uma imagem religiosa e seu potencial milagroso, uma categoria particular de imagem. $\mathrm{O}$ artista concebeu plasticamente uma imagem que não seria apenas um objeto material que representa uma divindade, mas também uma imagem religiosa que, em reposta ao ataque iconoclasta, adquiriu e manifestou características sobrenaturais no mundo, neste caso jorrou sangue.

Como já apontamos neste capítulo, a ortodoxia cristã não elaborou textos a respeito das imagens milagrosas, mas sim escritos e normativas conciliares aprovando o culto às imagens religiosas, sob a forma de dulia. Comumente, quando o tema do poder milagroso das imagens aparece em alguns escritos, é de forma tangencial, como a Questão 54 do Tomo III da Suma Teológica, de Tomás de Aquino. No entanto, este texto é importantíssimo para o que iremos apresentar aqui, pois ao discutir se o corpo de Cristo ressurgiu inteiro, ele termina o artigo 2 desta questão concluindo que o sangue que as igrejas têm guardado em seus relicários não seria o sangue do Cristo humano, mas sim do Cristo-imagem, que milagrosamente sangra quando atacada:

Todo o sangue corrido do corpo de Cristo, pertencendo realmente à natureza humana, ressurgiu com o seu corpo. E o mesmo devemos dizer de todas as partículas realmente pertencentes á natureza humana em sua integridade. Quanto ao sangue conservado por certas igrejas como relíquias, esse não correu do lado de Cristo; mas é considerado como tendo jorrado milagrosamente de alguma imagem sua, objeto de qualquer violência ${ }^{366}$.

Segundo Didi-Huberman, Aquino, para resolver a questão 54, "Se o corpo de Cristo ressurgiu inteiro, e sobre a substância do sangue de Cristo, suas relíquias e o seu culto", optou pela solução da ação milagrosa da imagem, em que o sangue de Cristo fora compreendido como transubstancial, que "transita perpetuamente entre um corpo glorioso e uma imagem. Seria a própria transubstância da imagem como uma virtude de encarnação" ${ }^{367}$. Ou seja, a substância em forma de sangue que escorreria das imagens seria a manifestação física do corpo glorioso de Cristo, seu corpo espiritual que não se sujeitaria mais às leis do espaço e do tempo ${ }^{368}$. Algo semelhante ao que teria acontecido

\footnotetext{
366 AQUINO, Tomás. Suma Teológica, Parte III. Questão 54. Art. 2. Versão online: http://permanencia.org.br/drupal/node/3512. Acesso em 12/11/2015

367 "Comme tel, il transite perpétuellement entre un corps glorieux et une image. Il serait ainsi la substance même de l'image en tant que vertu d'incarnation.” DIDI-HUBERMAN, Georges. L'image ouverte: motifs de l'incarnation das les artes visuels. Paris: Gallimard, 2007, p. 183.

368 “A realidade glorificada de Cristo, com efeito, através da efusão do Espírito Santo, é participada de modo misterioso, mas real, também a todos aqueles que n'Ele crêem.” João Paulo II, Audiência: 4/11/1998. Acesso em 01/12/2015.
} 
no milagre do Cristo da Paciência de Madri, resultante de uma violência contra um crucifixo e que teria abalado os devotos católicos madrilenhos, não só pelo sofrimento da imagem, mas também pela memória do sofrimento de Cristo.

Devemos lembrar que toda a violência ${ }^{369}$ que se encerra nos passos da Paixão de Cristo passou a ser reconhecida pelos cristãos como momento da redenção e da purificação:

Cristo, porém, veio como sumo sacerdote dos bens vindouros. Ele atravessou uma tenda maior e mais perfeita, que não é obra de mãos humanas, isto é, que não pertence a esta criação. Entrou uma vez por todas no Santuário, não com o sangue de bodes e de novilhos, mas com o próprio sangue, obtendo redenção eterna. De fato, se o sangue de bodes e de novilhos, e se a cinza da novilha, espalhada sobre os seres ritualmente impuros, os santifica purificando seus corpos, quando mais o sangue de Cristo que, pelo Espirito esterno, se ofereceu a si mesmo a Deus como vítima sem mancha, há de purificar a nossa consciência das obras mortas para que prestemos culto aos Deus vivo ${ }^{370}$

Deste modo, a figuração do sangue de Cristo representa o preço pago pelo filho de Deus para a salvação, símbolo do amor e da nova aliança ${ }^{371}$. No caso da pintura de Rizi, ela é símbolo também da violência sofrida por Cristo e revivida em Madri por aquela "perfídia cega". Devemos recordar que, antes do caso de Madri, muitas lendas de crucifixos sangrantes circularam por toda a cristandade. A lenda da Passio Imaginis ${ }^{372}$, a Paixão da Imagem de Cristo, é referente ao milagre que teria ocorrido em Beirute, no século IV. Como já apontamos no capítulo 2 desta dissertação, tal lenda conta que um grupo de judeus ultrajou um crucifixo com a intenção de reencenar a paixão de Cristo, quando este suou e verteu sangue:

Pisotearam a imagem e renovaram nela os tormentos sofridos pelo Senhor na sua Paixão. Quando perfuraram seu flanco com uma lança dali brotaram abundantemente sangue e água, que encheram um vaso. Espantados, os judeus levaram o sangue para a sinagoga e todos os enfermos que foram ungidos com ele

https://w2.vatican.va/content/john-paul-ii/pt/audiences/1998/documents/hf_jp-ii_aud_04111998.html

${ }^{369}$ Como observou Caroline Bynum, diferentemente do culto eucarístico, o culto ao sangue de Cristo esta relacionado diretamente com a violência "a complex image of violence". BYNUM, Caroline. The Blood of Christ in the Later Middle Ages. Church History, v.71, $\mathrm{n}^{\circ}$ 4. Chicago: Cambridge University Press, 2002, p. 691.

${ }^{370}$ Epístola aos Hebreus, IX, 11-14. In: BÍBLIA de Jerusalém. São Paulo: Paulus, 2011.

371 PÉREZ GONZÁLEZ, Silvia Maria, SÁNCHEZ HERRERO, José. La cofradía de la sangre de Cristo Sevilla: La importancia de la devoción a la preciosa sangre de Cristo en el desarrollo de la devoción y la imaginería de la Semana Santa. Aragón en la Edad Media. Zaragoza, 1999, nº14-15, p 1440.

${ }^{372}$ No decorrer dos séculos ocorreram uma serie de mudanças na lenda do Cristo de Beirute, por isto aqui, optamos apenas em descrever os "eventos" centrais. 
ficaram imediatamente curados. Então os judeus contaram tudo que acontecera ao bispo local e concordaram em receber a fé em Cristo e o batismo. [...] Depois dito todos os judeus consagraram suas sinagogas como igrejas que se difundiu, pois anteriormente apenas o altar era consagrado. Devido a este milagre, a Igreja determinou que em 27 de novembro ou, como se lê em outros lugares, em 5 de novembro, sejam rememorada a paixão do Senhor. Por isso foi consagrada em Roma uma igreja em honra de Salvador na qual se conserva uma ampola com seu sangue e se realiza esta festa solene. ${ }^{373}$

O mais interessante em ressaltar é como esta lenda reverberou na Península Ibérica desde o século XII, como, por exemplo, no caso da lenda do Cristo de Burgos e outros tantos que depois surgiram, mantendo-se viva no imaginário cristão ibérico, pelo menos até o início do século XVIII ${ }^{374}$.

Apesar de Rizi figurar o crucifixo como objeto estático, embora sangrante, percebemos claramente sua intenção de representar uma imagem e não o Cristo "em pessoa" na Cruz - ou, como poderíamos dizer, trata-se da representação de um crucifixo, e não do crucificado. No caso de pinturas que figuram objetos visuais "animados" em reposta a ataques iconoclastas encontramos apenas duas imagens, além das do Caso do Cristo da Paciência de Madri.

Uma é uma pintura do mestre português Pedro Nunes, conhecida como Nossa Senhora do Carmo e São Simão Stock (ou Santo Alberto) combatendo a iconoclastia (Figura 67), e se encontra na Igreja Nossa Senhora do Carmo de Évora. Nesta pintura vemos duas imagens sangrando (Figura 68), mas não com tanta abundância como na pintura de Rizi. Notamos que a opção do mestre eborense para compor a cena do milagre foi a sobreposição dos planos físicos e sobrenaturais, com a presença de elementos figurativos como anjos em meio a nuvens e raios, sobre a qual já tratamos em outra ocasião $^{375}$.

\footnotetext{
${ }^{373}$ VARAZZE, Jacopo de. Legenda Aurea: vida de santos, 2003, pp. 770-771.

${ }^{374}$ Ver livro I ANGUIANO, Mateo de. La nueva Jerusalen en que la perfidia hebraica reitero con nuevos ultrages la passion de Christo en su ss. imagen. del Crucifixo de la Paciencia en Madrid, 1709.

375 AMARAL, Debora Gomes Pereira. Apresentação: Nossa Senhora do Carmo e São Simão Stock combatendo a iconoclastia: a figuração do poder milagroso da imagem religiosa em uma pintura portuguesa setecentista. Trabalho apresentado no $\mathrm{V}$ Encontro Internacional A Imagem Medieval: História e Teoria, LATHIMM-USP. 2014, AMARAL, Debora Gomes Pereira, Imagens Sangrantes: a manifestação milagrosa das imagens de culto em uma pintura do mestre eborense Pedro Nunes (1586-1637). Trabalho apresentado no XI EHA - Da percepção à palavra: Luz e cor na História da Arte, 2015.
} 


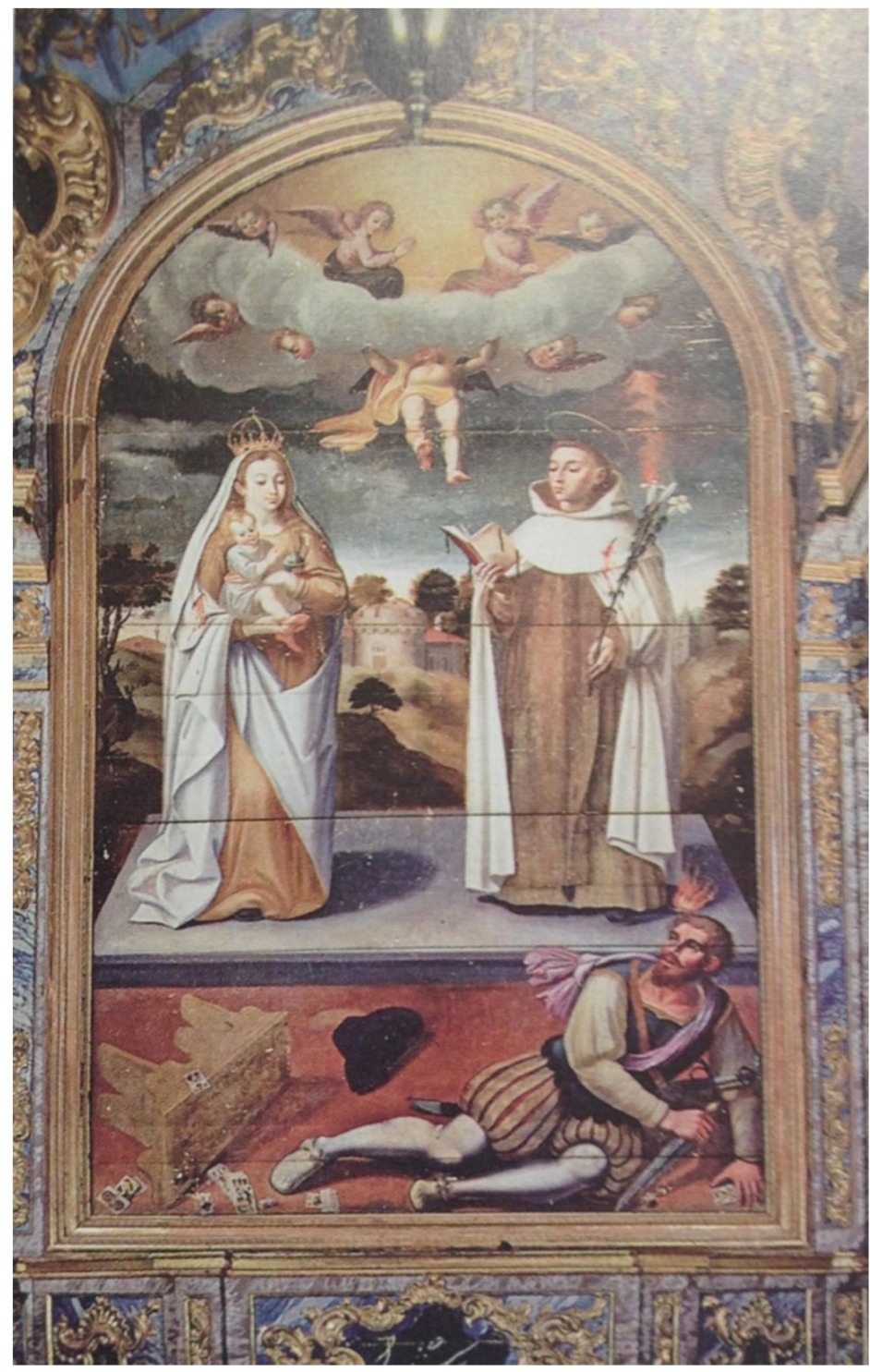

Figura 67 - Nossa Senhora do Carmo e São Simão Stock combatendo a iconoclastia, 1620-1625, óleo sobre madeira, Igreja Nossa Senhora do Carmo de Évora.

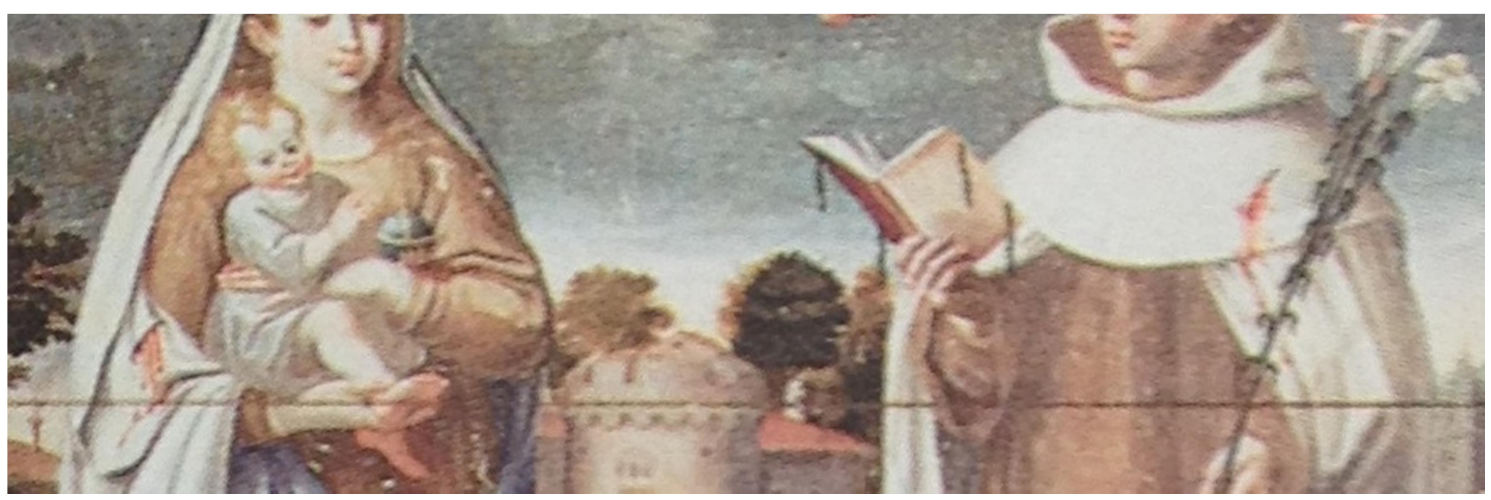

Figura 68 Detalhe da Figura 67. 
A outra imagem é uma gravura de Gerónimo Vilagrasa, gravada entre as páginas 454-455 da obra de Juan Bautista Ballester, Identidad de la imagen del $S$. Christo de S. Salvador de Valencia, impressa em 1672 (Figura 69). Esta gravura representaria um retábulo desaparecido da catedral de Valência, para a capela da Passio Imaginis. Ou seja, é uma representação de um retábulo desaparecido, que estaria na capela que fora construída em homenagem a um crucifixo milagroso conhecido como Cristo do Resgate (que segundo a lenda seria o de Beirute):

Exponía que las tres tablas eran de antiquísimo y valiente pincel, que la principal representaba la imagen en el suelo de la sinagoga, los oprobios de los judíos, y la lanzada y el manar sangre y agua, la del lado del Evangelio el milagro del paralítico, primero de los realizados con los fluidos de la talla; y la de la Epístola al obispo bautizando a los judíos. Además, sobre esta iconografía señala que era poco habitual en España, aunque cita el mismo tema en la iglesia de santa Catalina de la misma ciudad. Sobre las figuras del grabado reconocía Ballester que no conseguían mostrar la antigüedad del retablo. En este caso la limitación podemos justificarla por dos razones: una, la que suponía interpretar la pintura mediante el grabado; y dos, y sobre todo, por la incapacidad de los artistas formados en el naturalismo en representar formas figurativas del pasado. ${ }^{376}$

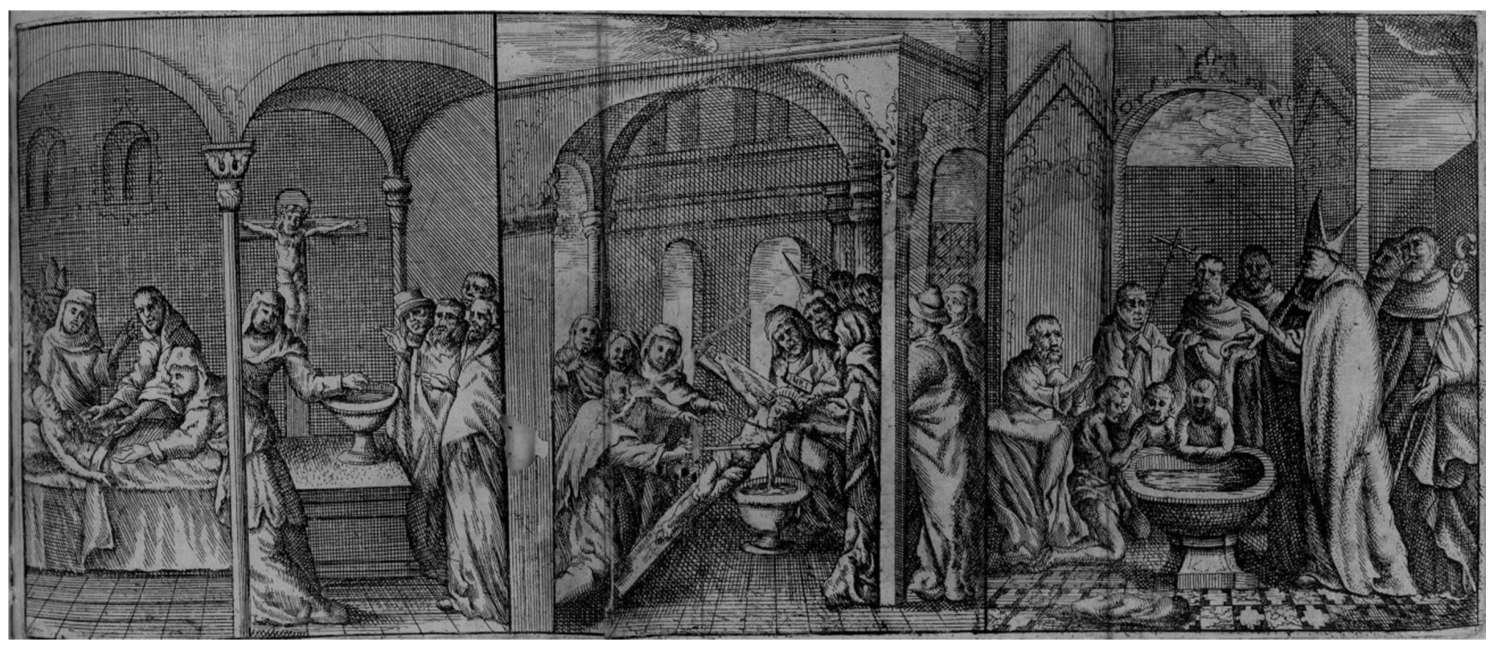

Figura 69 - Retablo de la capilla Passio Imaginis, catedral de Valencia en la obra de Juan Bautista Ballester, Identidad de la imagen del S. Christo de S. Salvador de Valencia. Valencia, Gerónimo Vilagrasa, 1672, pp. 454-455, Biblioteca Nacional, Madrid.

Na parte central da imagem podemos observar que o gravador compôs um grupo de pessoas profanando um crucifixo com instrumentos pontiagudos, e de seu

\footnotetext{
${ }^{376}$ ARCINIEGA GARCÍA. Luis. La Passio Imaginis y la adaptativa militancia apologética de las imágenes en la Edad Media y Moderna a través del caso Valenciano, 2012, p. 81.
} 
peito escorre um líquido para dentro de um elemento semelhante a uma pia batismal. Mesmo esta imagem sendo composta por técnica e suportes diferentes, a composição dos elementos da gravura (pessoas, armas, crucifixo), como também a maneira de figurar o milagre, é bastante semelhante à da pintura de Rizi.

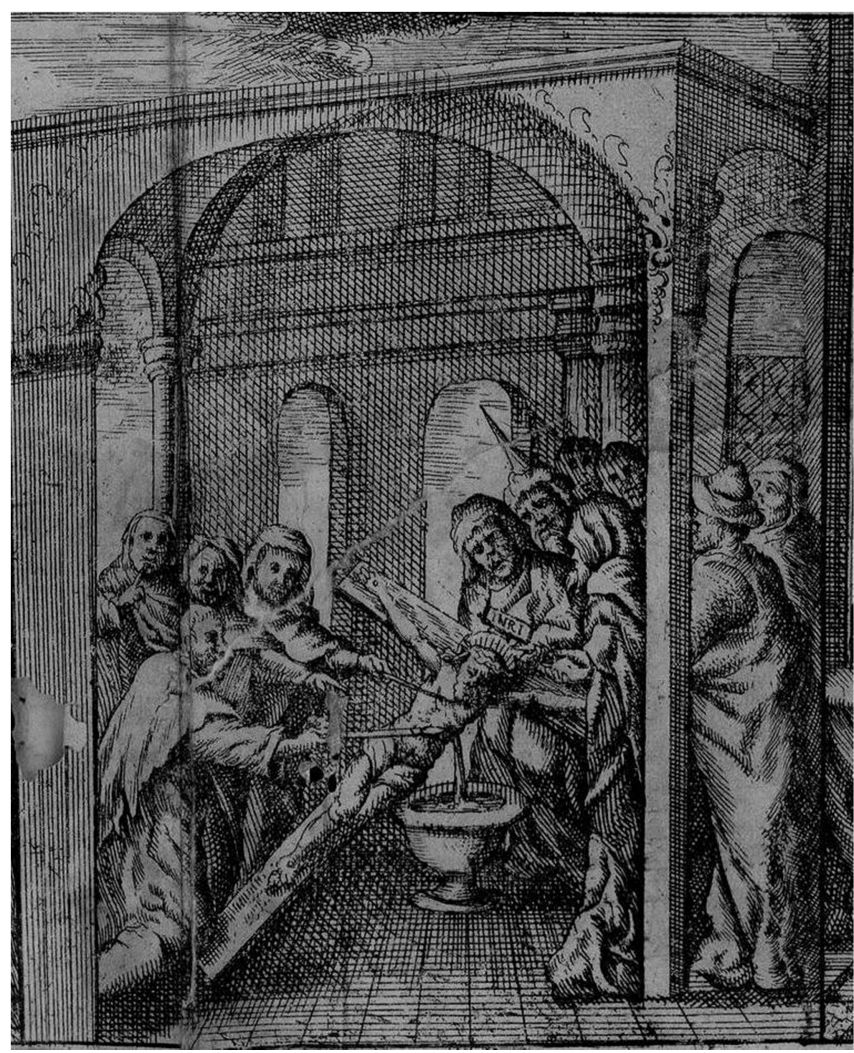

Figura 70 - Detalhe da Figura 69 


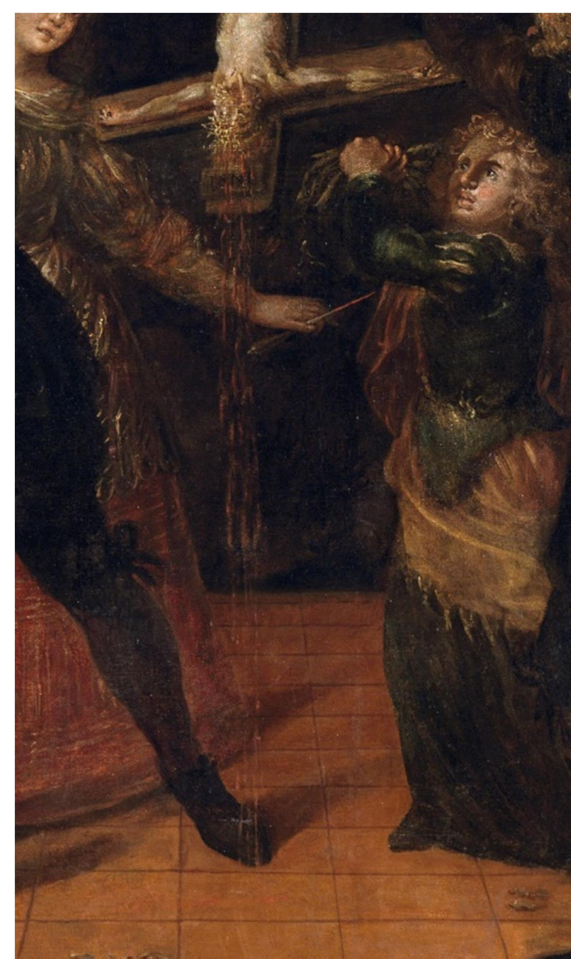

Figura 71- Detalhe da Figura 66

Assim posto, na gravura, e mais ainda na pintura do mestre madrilenho, parecenos que a figuração do sangue que escorre das chagas (Figura 71), a cor e o seu movimento, a mancha nos instrumentos (Figura 72), a postura dos verdugos, tudo isso deixa clara a referência ao momento da flagelação. 


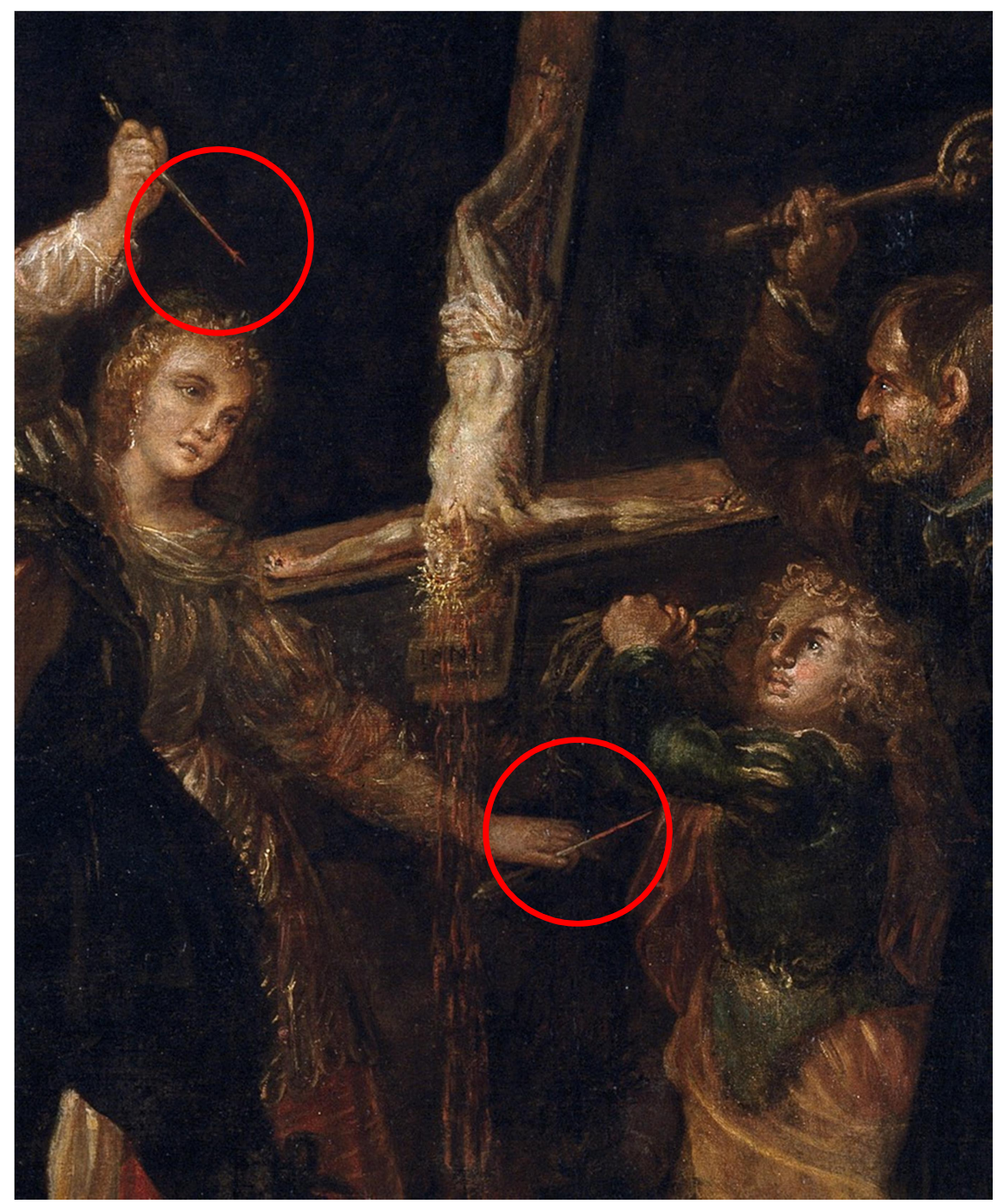

Figura 72 - Detalhe da Figura 66

Apesar de ser um crucifixo, e da nítida aproximação com o momento da crucificação quando Longuinho perfura a pele de Cristo morto que milagrosamente sangra, também percebemos que algumas pinturas que figuram o momento da flagelação ou do caminho da Cruz trazem elementos que podemos relacionar às ações dos iconoclastas e ao sofrimento da imagem, que sangra milagrosamente, como podemos observar em pinturas como na Flagelación del Señor (Figura 73), de Juan de Sevilla Romero, ou La Flagelación de Jesús (Figura 74), de pintor anônimo. 


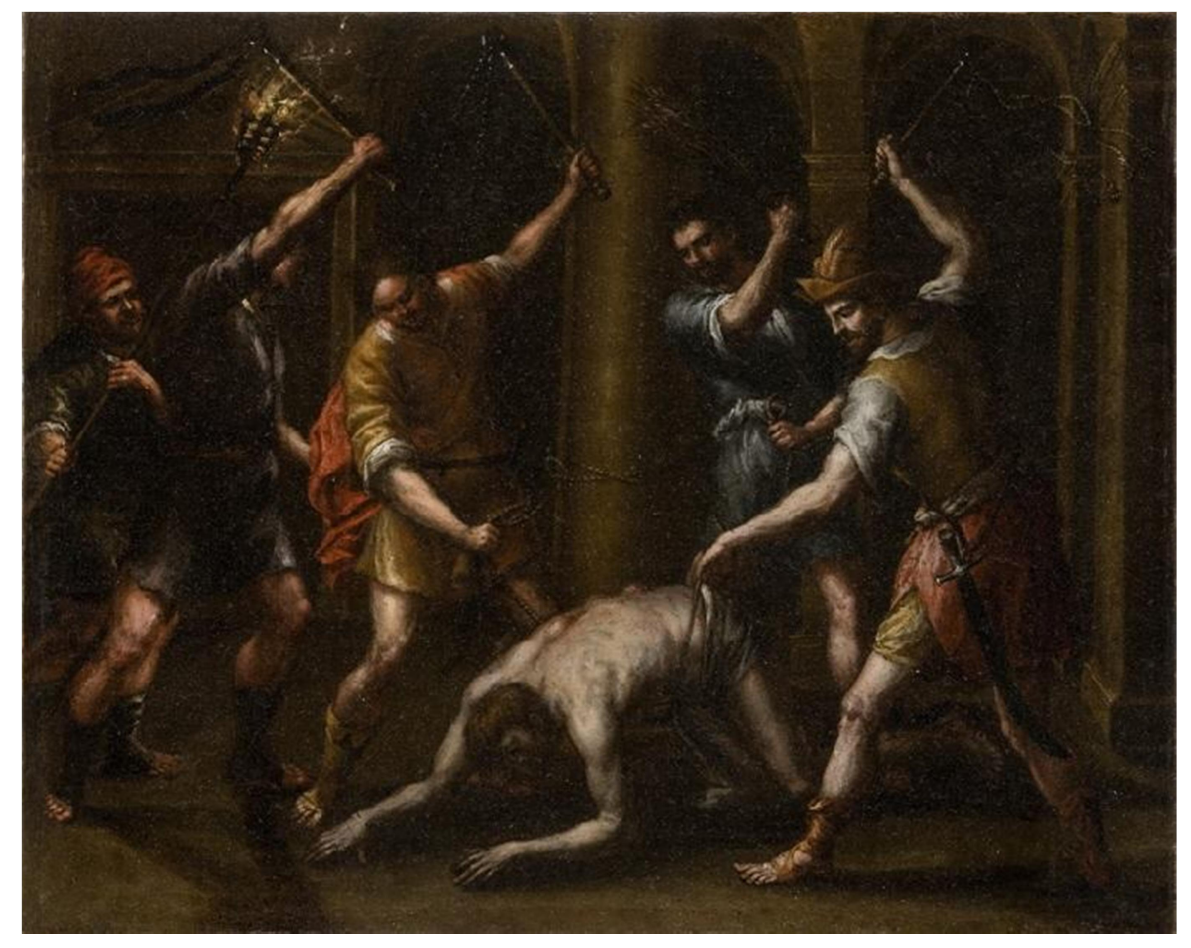

Figura 73 - La Flagelación de Jesús, c. 1700, óleo sobre tela, 38 cm x 48 cm, Museo de Huesca [00116].

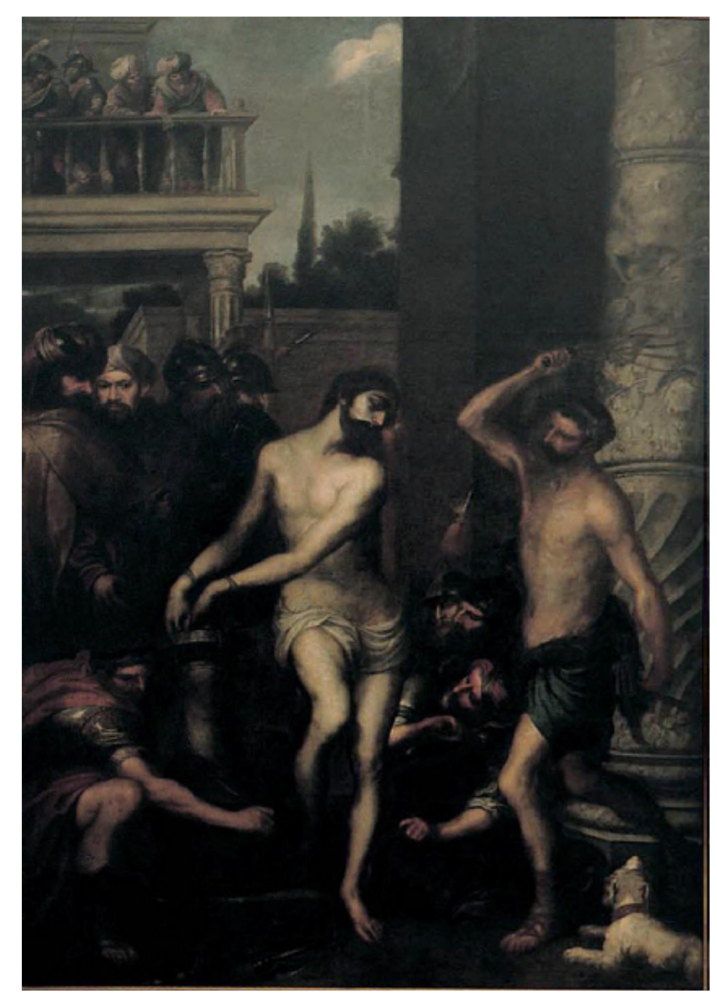

Figura 74 - Flagelación del Señor, c. 1670, óleo sobre tela, $336 \mathrm{~cm}$ x $226 \mathrm{~cm}$, Juan de Sevilla Romero, Museo de Bellas Artes de Granada [CE0166]. 
O mesmo podemos ponderar quando lemos um trecho dos inúmeros sermões proclamados em rituais de expiação para o agravo do crucifixo:

Açotaron esta santa Imagen muchas vezes, e en tã repetidas, quanto sufridas injurias, quexose Christo y habloles. Los açotes animaró la voz [...] Dio sangre la Imagen.[...] Pues vea el judío correr la sangre a la Imagen, oiga hablar con animadas voces para que a fuerza de tocar el milagro cobre la fe perdida... ${ }^{377}$

Ainda podemos correlacionar o sangramento do crucifixo com as lendas de caráter antijudaico sobre profanação de hóstias, que milagrosamente teriam sangrado. Devemos lembrar que, para a fé cristã, a natureza mística da eucaristia significa a presença física de Cristo na hóstia e sua relação com a Paixão ${ }^{378}$. E que, por incentivo da Igreja:

A celebração mística transformou-se em uma espécie de repetição literal da Paixão, pois em cada missa, o Cristo se sacrifica novamente para a salvação da humanidade, doando-se nas espécies sacramentais da eucaristia. E é por esse sacrifício, que ocorre em toda missa, que é possível aos cristãos a sua salvação. ${ }^{379}$

Desta feita, a profanação da hóstia ${ }^{380}$ funciona também como uma agressão à Cristo e a fé cristã, pois, ao ser consagrada durante o ritual da missa, ela se transforma no crucificado. E, em muitas lendas, o resultado da agressão à hóstia consagrada é ela verter sangue, reafirmando a presença do corpo real de Cristo. Tais lendas também foram representadas pictoricamente em tábuas de retábulos espanhóis do século XIV e $\mathrm{XV}$.

O retábulo de Vallbona de les Monges de Urgel $(108,8$ × 222 × 8,7 cm), conservado no Museu de Arte Nacional da Catalunha (Figura 75), na parte inferior à direita do espectador tem representadas duas cenas que figuram a profanação e o milagre da hóstia sangrar (Figura 76). Na cena da esquerda, vemos dois homens barbados, e um deles atinge com um punhal uma hóstia sobre uma mesa, que verte

\footnotetext{
${ }^{377}$ PEÑA, Juan Antonio de la. O Discurso en exaltación de los improperios que padeció la Imagen de Christo N.S. a manos de la perfidia Judaica, 1632, fol $17 \mathrm{r}$

${ }^{378}$ LUBARINO, Doglas Morais. O Juizo Final e a Missa de São Gregório (MASP 428P): pintura retabular Eucaristica no final da Idade Média. 2015, pp. 130-133.

${ }^{379}$ LUBARINO, Doglas Morais. O Juizo Final e a Missa de São Gregório (MASP 428P): pintura retabular Eucaristica no final da Idade Média. 2015, p. 132.

380 Segundo Barral foi aparti do seculo XIII que na Europa cristã começaram a surgir as lendas das hóstias sangrantes. RODRIGUEZ BARRAL, Paulino. Eucaristía y antisemitismo en la plástica gótica hispánica, 2006, pp. 279-348.
} 
sangue, e na cena da direita, vemos três homens, e ao centro uma lança com uma hóstia com manchas vermelhas, o que sugere sangue.

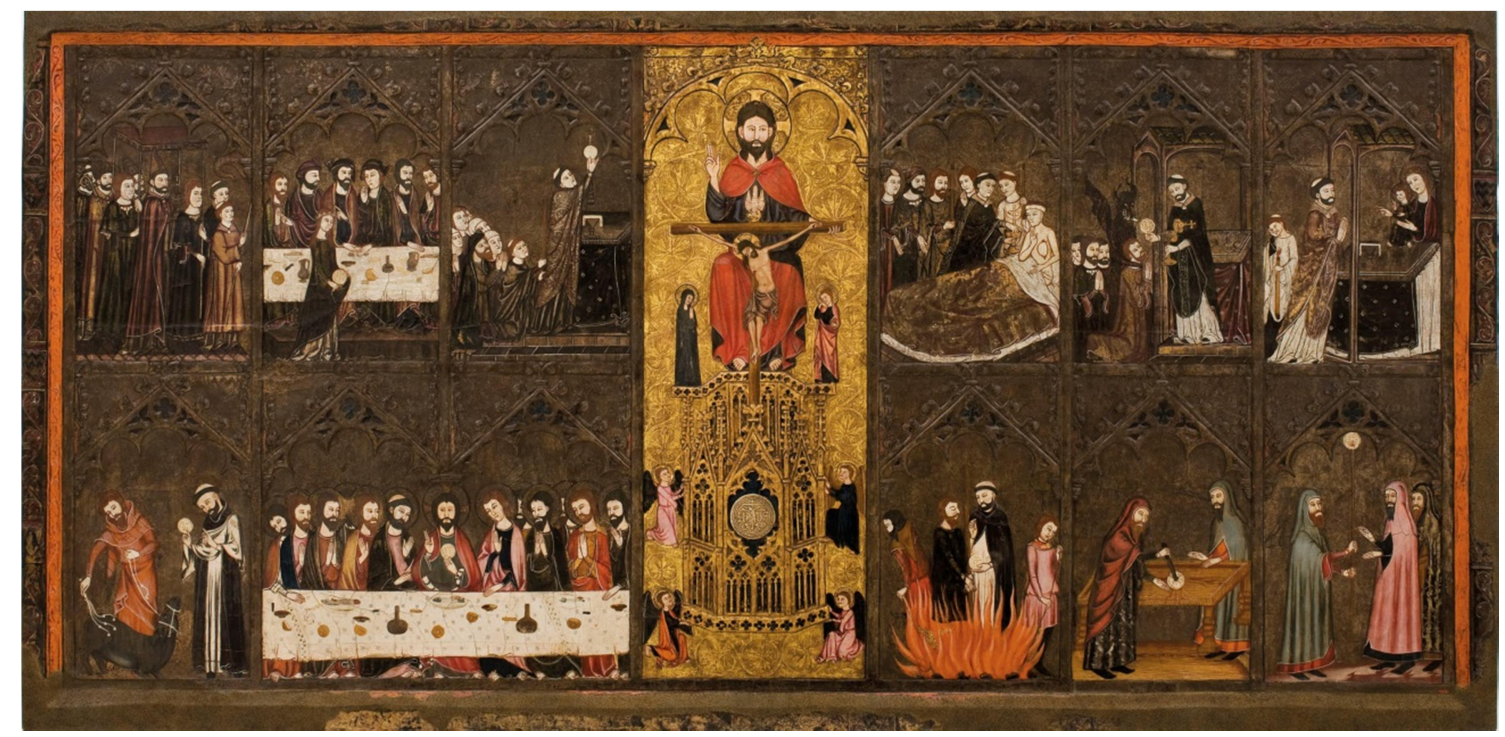

Figura 75 - Retábulo de Vallbona de les Monges de Urgel, 108,8 cm x $222 \mathrm{~cm}$, Museu de Arte Nacional da Catalunha [009920-000]. 


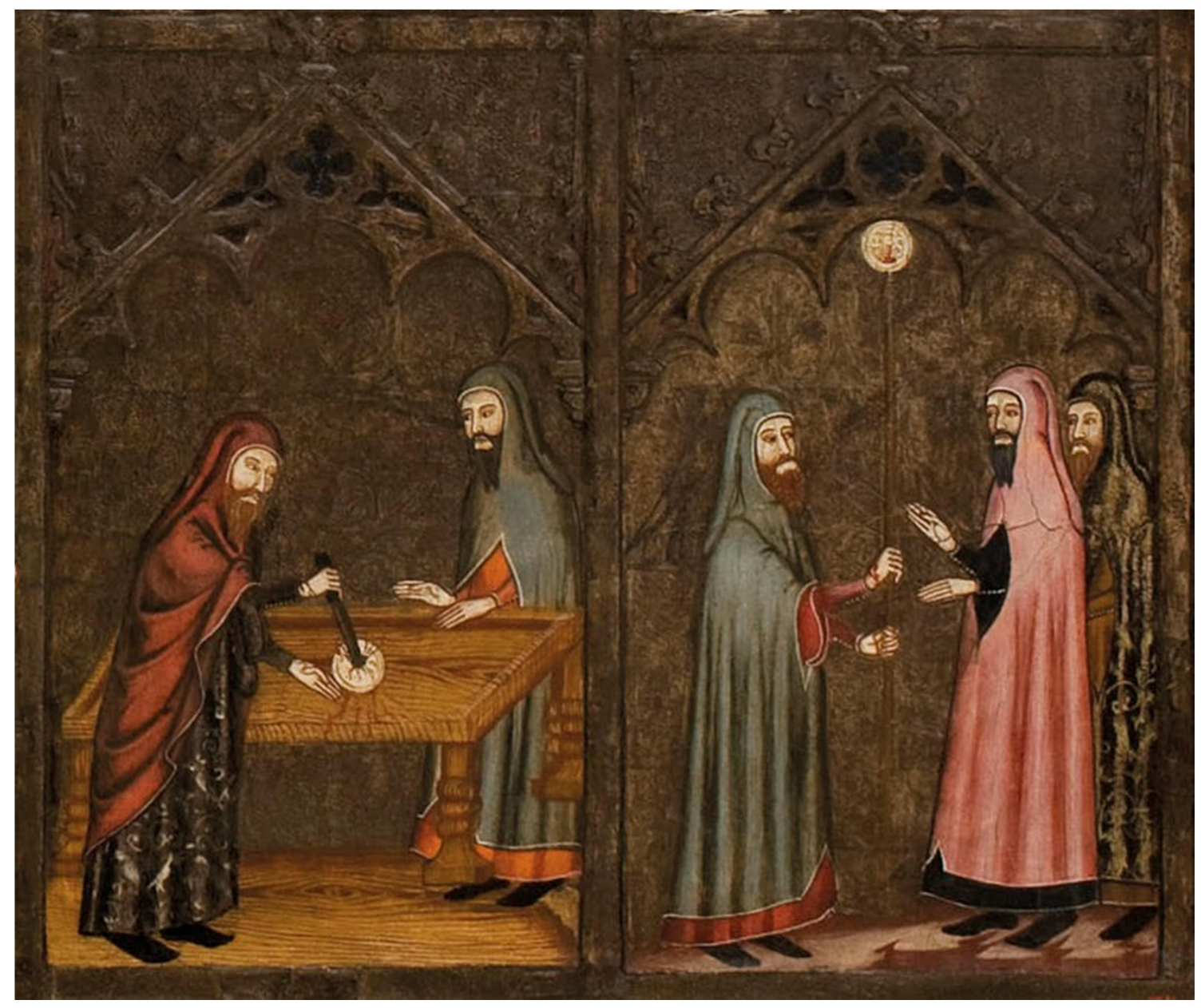

Figura 76 Detalhe da Figura 75.

No mesmo museu encontramos outro retábulo em que foram figuradas uma profanação e o milagre da hóstia. É o retábulo à Virgem (Figura 77), procedente do monastério de Santa María de Sigena (Villanueva de Sigena, Huesca). E na parte inferior à direita do espectador vemos a cena de um crime ritual (Figura 78). 


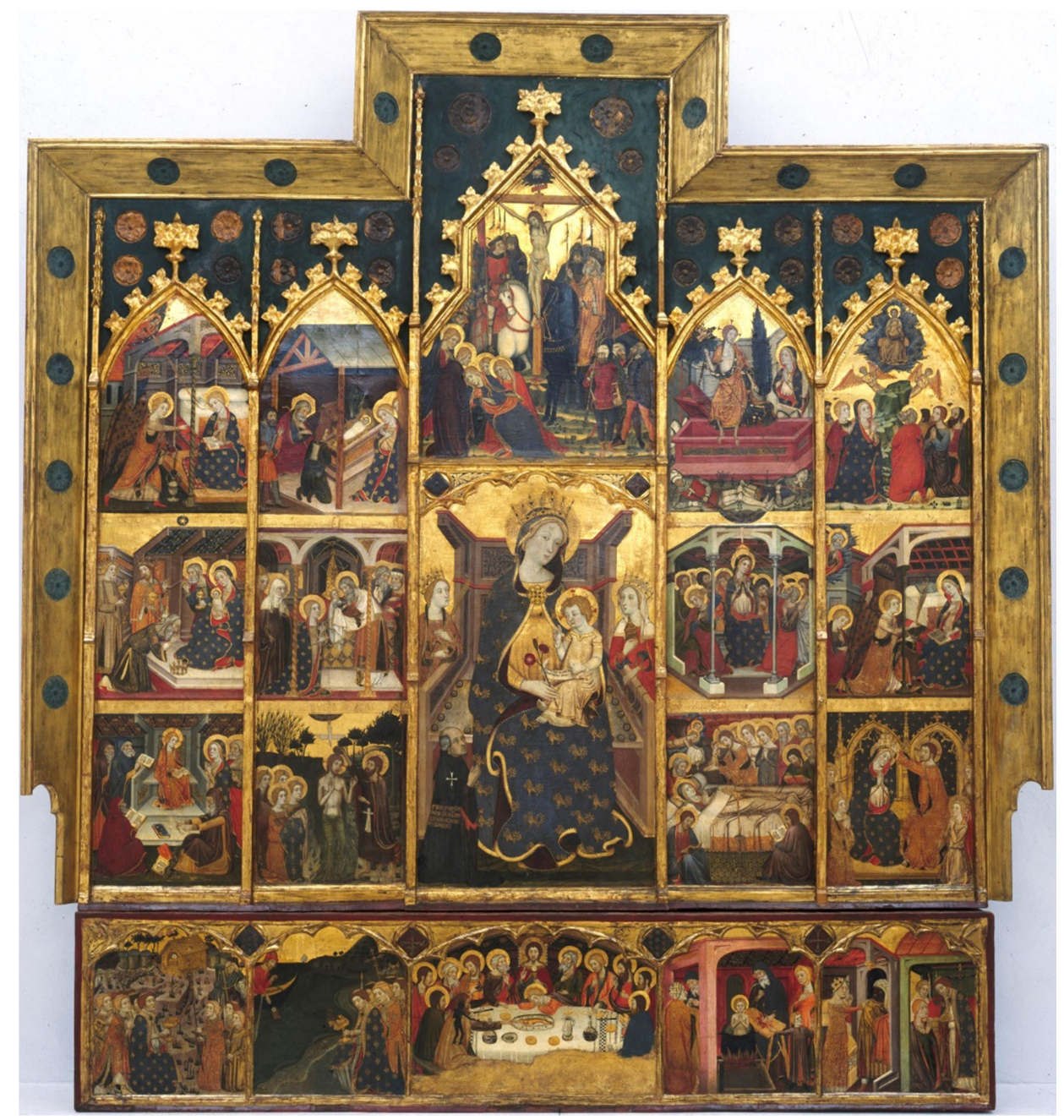

Figura 77 - Retábulo à Virgen, Museu de Arte Nacional da Catalunha [015916-CJT]. 


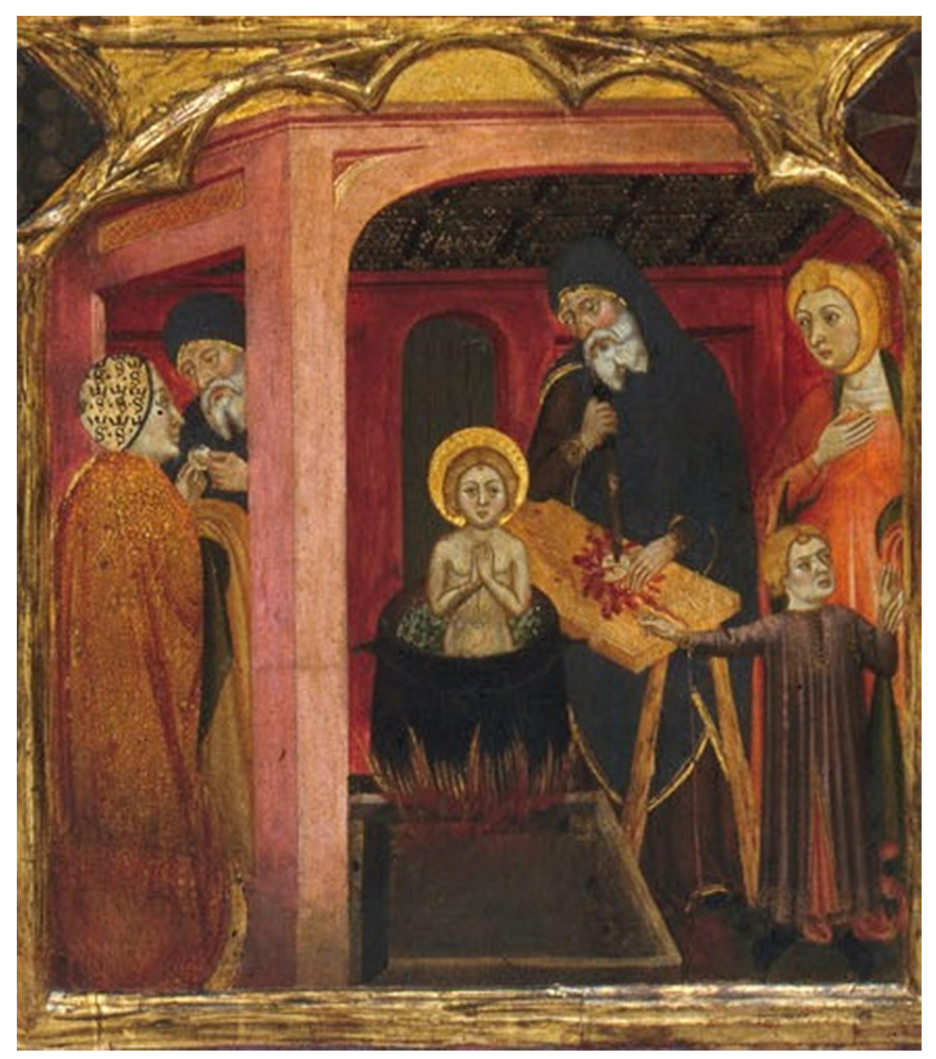

Figura 78 - Detalhe da Figura 77.

Essas figurações do milagre da hóstia, apesar de separadas por três séculos das pinturas sob nossa análise, delas se aproximam, na medida em que a hóstia era compreendida como o corpo físico de Cristo, e a sua profanação nada mais seria do que uma reencenação da Paixão. Segundo Rodriguez Barral, estes gestos de apunhalar e atravessar com uma lança são tanto uma memória do momento em que Cristo, já morto, é golpeado e verte sangue como também a demonstração da presença de Cristo na eucaristia $^{381}$. Quanto à figuração, podemos interpretar a hóstia como um objeto visual; mesmo que sua forma não seja uma representação das qualidades físicas de Cristo humano, ela é a transubstância deste corpo, e como apontou Espeso Pereda,

aunque la experiencia de la eucaristía y de las imágenes religiosas pueda parecer muy distante, en la Europa medieval no lo era tanto, especialmente si tenemos en

${ }^{381}$ RODRIGUEZ BARRAL, Paulino. Eucaristía y antisemitismo en la plástica gótica hispánica, 2006, pp. 289-290. 
cuenta que la hostia, el alimento transusbstanciado, no era tanto digerido en la eucaristía cuanto consumido visualmente en el momento de su alzamiento ${ }^{382}$

Por este pressuposto, podemos apontar a aproximação destas imagens com as pinturas do caso do Cristo da Paciência, tanto na figuração, pois as imagens do Museu Nacional de Artes da Catalunha representam pictoricamente um objeto visual religioso (consagrado) que ao ser agredido por supostos judeus reage sangrando, como também na concepção do objeto milagroso que sangra após um ataque. Ante o ataque, a hóstia manifesta-se como carne, e o crucifixo encarna seu protótipo.

Como pudemos notar, apesar da existência de algumas lendas de crucifixos sangrantes, a sua representação pictórica é rara. Mesmo o relevo da Passio Imaginis, a representação visual mais conhecida da lenda do Cristo de Beirute (Figura 34), não concebe o crucifixo sangrando, o que nos levou a concluir que Francisco Rizi precisou inovar para conceber a figuração da ativação milagrosa do crucifixo que sangra.

\section{A dor e o sofrimento de uma imagem}

Em um texto muito interessante do antropólogo espanhol Manuel Delgado, Exorcismo y martírio de las imágenes: la iconoclastia como violencia corporal, o autor faz uma reflexão não só de como os cristãos católicos compreendiam as imagens religiosas, mas também de como os iconoclastas as entendiam. No que diz respeito aos cristãos, ele trata da intercambialidade entre a representação e o representado, e das suas potencialidades "viventes". Já para os iconoclastas, as imagens teriam potências demoníacas, ou seja, pela perspectiva da idolatria elas continuariam sendo receptáculos do sobrenatural, só que diabólicos, o que poderia ser explicado pelas maneiras que as imagens foram atacadas: "rompendo las narices, las cabezas y hasta los óganos sexuales de las estatuas que encontraban en las iglesias, impulsados por um fervor religioso" 383 . Para o antropólogo, esta seria uma evidência de que os algozes também compreendiam que estas imagens seriam mais do que pedaços de madeira, e mais que

\footnotetext{
${ }^{382}$ ESPESO PEREDA, Felipe. Las imagens de la discordia: politica e poética de la imagen sagrada en la España del cuatrocientos, 2007, Posição 1122-5673.

${ }^{383}$ DELGADO, Manuel. Exorcismo y martirio de las imágenes : la iconoclastia como violencia corporal. In : MOLINA, Pedro e CHECA, Francisco. La función simbólica de los ritos. Barcelona: Icária, 1997, p. 379 .
} 
iconoclastia, suas ações seriam a da tortura e assassinato ${ }^{384}$. Por óbvio que não temos condições de extrapolar tal reflexão para os hereges que supostamente cometeram o ritual de reencenação da Paixão por meio da agressão ao crucifixo, mas podemos fazer um paralelo com a maneira como o ataque foi figurado nas pinturas da capela do Cristo da Paciência.

Quando observamos essas imagens, supondo que tais profanações tivessem de fato ocorrido, nos questionamos o porquê deste ataque e, também de como sua representação pictórica gerou tamanha comoção entre os católicos espanhóis. Claro que já apontamos aqui vários motivos, como o cristocentrismo hispânico, a desconfiança dos cristãos-novos e o respeito às imagens religiosas. Ademais, para muitos crentes havia a ideia de que as imagens em si contivessem também o seu protótipo, ou ainda, muitas imagens, ao adquirirem fama de milagrosas, acabaram por assumir um status divino, no qual a veneração dirigia-se ao próprio objeto visual, e não mais seu protótipo $^{385}$. Por este ponto de vista, se um fiel, ao contemplar as pinturas em que Cristo está sendo agredido, observa que ele questiona Porqve me maltratais ..., ou seja, manifesta sofrimento, ou sangra aos golpes do açoite, resta-lhe claro que esse crucifixo não é mais um simples objeto, mas antes ou o próprio Cristo encarnado sofrendo novamente, ou, pelo menos, um crucifixo verdadeiramente milagroso.

Como dissemos anteriormente, não podemos esperar uma única interpretação da figuração pictórica religiosa, ainda mais se esta trata de acontecimentos místicos. Desta forma, apontar a possibilidade da interpretação do sofrimento da imagem faz parte do desvio figural ${ }^{386}$, de um paradoxo em que as leis da natureza não fazem sentido, pois o que opera naquelas narrativas visuais são leis sobrenaturais ou divinas, em que as imagens religiosas, capazes de adquirir "vida" também são passíveis de sofrer quando atormentadas.

\footnotetext{
${ }^{384}$ DELGADO, Manuel. Exorcismo y martirio de las imágenes : la iconoclastia como violencia corporal, 1997 , p. 396.

${ }^{385}$ Além da imagens aqueiropoiéticas, podemos citar como exemplo para a Espanha o Cristo de Burgos ou de Medinaceli. E para o Brasil, não podemos esquecer de Nossa Senhora Aparecida.

${ }^{386}$ DIDI-HUBERMAN, Georges. Poderes da figura. Exegese e visualidade na Arte Cristã, 1994, pp. 163174.
} 


\section{Considerações Finais}

Com nossa pesquisa de mestrado, cujo objeto de análise foram as quatro pinturas encomendadas para as paredes da Capela do extinto convento dos Capuchinhos da Paciência de Madri, aproximamo-nos de uma realidade histórica perpassada por diversas camadas que conformaram as relações sociais da Madri do século XVII, e a partir daí, estudamos os múltiplos papéis que as imagens religiosas desempenharam nesse contexto. A despeito das grandes generalizações necessárias para a compreensão dos tempos passados, foi ao focalizarmos nossas lentes nas pinturas que pudemos perceber as sutilezas que permeiam o caso do Cristo da Paciência, quando um crucifixo, ao sofrer um ataque iconoclasta, teria agido milagrosamente, sangrando e questionando as ações hereges.

Percebemos no decorrer de nossa pesquisa que, no Século de Ouro espanhol, havia um entrelaçamento de questões político-econômicas com as de caráter religioso, e como estas demandas foram fundamentais na configuração do Caso do Cristo da Paciência e da encomenda das pinturas. A conjuntura política e a crise econômica fizeram com que o Conde Duque de Olivares facilitasse a imigração de conversos portugueses para a Espanha. Tal atitude, apesar de favorecer os cofres da monarquia, não fora vista com bons olhos, tanto pelos fiéis católicos como pela igreja da Espanha. A convivência com a gente da nação trouxe à tona a desconfiança e o preconceito, por séculos já arraigados entre as comunidades cristãs.

Por outro lado, na esfera religiosa, as imagens religiosas continuavam exercendo as múltiplas funcionalidades entre os fiéis. Em certos casos, tais funcionalidades foram potencializadas, ou porque a Igreja cristã estava oficialmente dividida entre aqueles que continuavam cultuando as imagens e aqueles que as rejeitavam, ou porque a piedade popular possuía uma relação mais próxima dos objetos visuais e a ortodoxia fazia-lhe vistas grossas, afora que devemos lembrar que as inúmeras lendas de imagens que adquiriram poderes milagrosos adquiririam fama.

Enfim, o que notamos é que a conformação social ao longo da história da Espanha proporcionou-lhe, no século XVII, uma conjuntura em que as relações sociais, a vida política e econômica e o cotidiano das pessoas tornaram-se amparadas na 
religiosidade. Assim podemos compreender a extrema necessidade da expiação - a expiação de pecados pessoais por meio do flagelo corpóreo, das doações às Igrejas e irmandades. Como também a expiação social, através da Inquisição. A Inquisição Espanhola, sob o mando da Coroa, foi a instituição que por excelência conduzia tais atos, e assim também conseguia impor um modo de vida. Toda a sociedade participava dessa expiação de maneira mais ativa, ou apenas com sua aceitação.

A visualidade, o dar a ver, por meio de atos, do culto às imagens, das procissões e das flagelações, foi fundamental para a manutenção desse modo de vida. Do mesmo modo, na expiação comandada pela Inquisição, o dar a ver de toda aquela série de festividades cruéis que, para além do medo, eram capazes de gerar sentimentos de compunção e ao mesmo tempo de ódio do outro, e de despertar um desejo de continuar lutando por aquilo que se considerava ser a fé "verdadeira", garantia a perpetuação do status quo. A expiação pública dos réus do caso do Santo Cristo da Paciência, culminando com a edificação do convento e da igreja adornada com grandes pinturas que retrataram o suposto ataque iconoclasta e o milagre, foram episódios que parecem demonstrar tais modos de vida.

Parece-nos evidente, no que diz respeito ao culto às imagens religiosas, que a figuração centrada na agressão ao crucifixo e nos milagres sugere a anuência da devoção às imagens milagrosas. Pois, a despeito das normatizações e do descontentamento explícito de muitos clérigos, tais pinturas deixavam claro para o fiel espectador que, a despeito do controle eclesiástico sobre o culto católico, os objetos sagrados poderiam manifestar-se no plano terrestre. E, por outro lado, demonstrava-se que a ação iconoclasta, além de desrespeitar a fé, desrespeitava também todo um modo de vida pautado no controle religioso, em que o respeito às imagens era parte consubstancial do ser católico naquela Espanha dos setecentos. Desta feita, podemos dizer que a suposta heresia daqueles que não teriam se convertido verdadeiramente à fé católica teria resultado na exaltação da imagem religiosa e de seu potencial como agente intercessor do sobrenatural no mundo terrestre.

Também não podemos deixar de apontar que, ao investigar as imagens, descobrimos inúmeras outras fontes referentes ao caso do Cristo da Paciência, que não pudemos incluir neste estudo por ultrapassar o escopo de uma dissertação de mestrado. Mas não pudemos deixar de, pelo menos, cotejá-las e citá-las, e, deste modo, encontrar 
pistas de uma realidade amplificada do culto às imagens religiosas e a sua essência, ou seja, do seu potencial milagroso, abrindo assim margem para a continuidade futura de nossa investigação. 


\section{Referências}

\subsection{Fontes Escritas:}

Proceso de fe de Beatriz Enriquez - 1630/1633 - AHN - INQUISICIÓN, 140, Exp. 4a.

Proceso de fe de Fernán Báez - 1630/1632 - AHN - INQUISICIÓN, 140, Exp. 4b.

Proceso de fe de Victoria Méndez - 1630/1632 - AHN - INQUISICIÓN, 140, Exp. 4c.

Proceso de fe de Violante Méndez - 1630/1632 - AHN - INQUISICIÓN, 140, Exp. 4d.

Proceso de fe de Isabel Núñez Álvarez - 1630/1632 - AHN - INQUISICIÓN, 140, Exp. $4 \mathrm{e}$.

Proceso de fe de Elena Núñez - 1630/1632 - AHN - INQUISICIÓN, 140, Exp.4f.

Proceso de fe de Beatriz Rodriguez - 1629/1632 - AHN - INQUISICIÓN, 140, Exp. 4g.

Proceso de fe de Miguel Rodriguez - 1630/1632 - AHN - INQUISICIÓN, 140, Exp. 4h.

\subsection{Fontes Impressas:}

ANGUIANO, Mateo de. La nueva Jerusalén en la que la perfidia hebraica reiteró con nuevos ultrajes la Pasión de Christo en la sacrosanta imagen del Crucifijo de I Paciencia en Madrid y augustos y perennes desagravios de nuestros cathólicos monarcas D. Phelipe IV el Grande y D. Isabel de Borbón. Madrid: Impr. de Manuel Ruiz de Murga, 1709.

Anônimo. Aqui se contiene lo que sucedío en la casa de unos Hebreos, com uma figura de Christi que azotaran. Como fueron descibiertos y el castigo que les dieron. Barcelona: Esteban Liberos, 1632.

Anônimo. Relacíon del Auto de la fé, que se celebró en Madrid, Domingo a quatro de Julio de 1632.

AQUINO, Tomás. Suma Teológica, Parte III. Questão 54. Art. 2. Open Acess.

Disponivel em: http://permanencia.org.br/drupal/node/3512. 
BLEDA, Jaime Juan. Los Cuatrocientos milagros, y muchas alabaças de la Santa Cruz. Valencia, 1600.

BOYL, Francisco de. Sermón de los desagravios de Jesucristo, posteriores glorias de su Cruz y feliz escándalo del judío ... predicole en la festividad de la Cruz en el Santo Domingo Real de M.R.P. Alcalá de Henares: En la imprenta de Juan de Villadas Ordua, 1634.

CARDUCHO, Vicente. Dialogos de la Pintura: su defensa, origen, esse[n]cia, definicion, modos y diferencias. Madrid: Francisco Martínez, 1633.

CELANO, Tomás. Vida Segunda de São Francisco (1246-47). Braga: Editorial Franciscano, [2---], cap. IV.

ESPINA, Alonso de. Fortaleza da Fé, Livro III.

MAIMONIDES, Mose. Guia de los Descarriados y Perplejos - Maiomonides. Org: VALERA, Fernando, México: Editorial Oríon, 1947.

MOLANUS, Johannes. De Picturis et imaginibus sacris líber unus.

GOMEZ DE MORA, Juan. Auto de la fé celebrado en Madrid ensta año de MDCXXXII. Madrid: Imprenta de Francisco Martínez, 1632.

GRANADA, Fray Luis de. Libro de la Oración y la Meditación (1557). In: Obras Completas XVIII. Madrid: FUE, 1994.

PACHECO, Francisco. Arte de la pintura, su antigüedad y su grandeza. Sevilla: Simón Fajardo, 1649.

PALEOTTI, Gabriel. Discorso intorno alle imagini sacre et profane diuiso in cinque libri. Doue si scuoprono varij abusi loro e so dichiara il vero modo che cristianamente si doveria osservare nel porle nenne chiese, nelle case et in ogni altro luogo, raccolto e posto insieme as utile dele anime per comissione di monsignore illustrissimo e reverendíssimo. 1582.

PALOMINO, Antonio. El museo pictórico y escala óptica: Tomo segundo. Practica de la pintura. Madrid: Imprenta de Sancha, 1714.

PARVICINO Y ARTEAGA, Hortencio Felix. Jesuchristo desagraviado o Oracion evangélica de los ultrages de Iesucristo...nueva i sacralegamente repetidos por unos hebreos. Madrid: Imprenta de Francisco Marínez, 1633.

PONZ, Antonio. Viage de España. Madrid: Ibarra, 1784. 
SORIA, Francisco. Sermón predicado en la solene octava que la Congregacios del Santo Ofício celebró en el real Convento de S. Domingo à los desagravios de Christo ofendido en su Imagen, Madrid: Imprenta de Francisco Martínez, 1634.

TALAVERA, Frey Hernando de, Católica Impugnación. Barcelona: Juan Flores, 1961.

TOLEDO (Diócesis). Sínodo. Constituciones sinodales del Smo. ... don Fernando, Cardenal Infante, administrador perpetuo del Arcobispado de Toledo, 1622.

WALDENSIS, Thommas. Doctrinale antiquitatum fidei Catholicae Ecclesiae adversus Wiclefitas et Hussitas ad vetera exemplaria recognitum \& notis illustratum. Livro III, cap. 179. Veneza, 1571.

\subsection{Bibliografía}

AGNOLIN, Adone. Jesuítas e selvagens: a negociação da fé no encontro catequético-ritual americano-tupi (séculos XVI-XVII). São Paulo: Humanitas, 2005.

ALBERO MUÑOZ, Maria de Mar. La investigación sobre Fisiognomía y expresión de las pasiones: objetivos y metodología. Panta Rei: revista de ciencia y didáctica de la historia. Murcia, 2008, pp. 233-248.

ALVAR EZQUERRA, Alfredo, La Inquisicio Española. Madrid: Akal, 1997.

AMARAL, Debora G. P. A Iconoclastia nas Cantigas de Santa Maria. In: XXII ENCONTRO ESTADUAL DE HISTÓRIA ANPHU - SP. Santos: 2014. Anais eletrônicos... $2014 . \quad$ Disposnível: http://www.encontro2014.sp.anpuh.org/resources/anais/29/1406772434_ARQUIVO_art igoAnpuhDeboraGPA.pdf

Nossa Senhora do Carmo e São Simão Stock combatendo a iconoclastia: a figuração do poder milagroso da imagem religiosa em uma pintura portuguesa setecentista. Trabalho apresentado no V ENCONTRO INERNACIONAL A IMAGEM MEDIEVAL: HISTÓRIA E TEORIA, LATHIMM-USP. São Paulo: 2014.

Imagens Sangrantes: a manifestação milagrosa das imagens de culto em uma pintura do mestre eborense Pedro Nunes (1586-1637). Trabalho apresentado no XI EHA - DA PERCEPÇÃO À PALAVRA: LUZ E COR NA HISTÓRIA DA ARTE - UNICAMP. Campinas: 2015.

ARCINIEGA GARCÍA. Luis. La Passio Imaginis y la adaptativa militancia apologética de las imágenes en la Edad Media y Moderna a través del caso Valenciano. Ars Longa. Valencia, 2012, n $^{\text {2 } 21, ~ p p ~ 71-94 . ~}$ 
ATERIDO, Ángel. Las relaciones entre escultura y pintura en el Madrid del siglo XVII. El caso de las capillas dedicadas a la Pasión. In: CARLOS VARONA, María Cruz de, CIVIL, Pierre, ESPESO PEREDA, Felipe, VICENT-CASSY, Cécile (coord.). La Imagen religiosa en la monarquía hispánica: usos y espacios. Madrid: Casa de Velázquez, 2008, pp. 151-170.

BARRIO MOYA, José Luis. Cristobal de Aguilera y el desaparecido Convento de los Capuchinos de la Paciencia de Cristo de Madrid. Anales del Instituto de Estudios Madrileños. Madrid, 1981, tomo XVIII, pp 187-191.

El pintor conquense Andrés de Vargas y una obra suya en Guadalajara. Wal-al-Hayara: Revista de Estudios de Guadalajara. [Guadalajara], 1991, nº18, pp 463-473.

BARROS, Maria Filomena Lopes de. Os Muçulmanos de Portugal: a lusofonia como metáfora (séc. XII-XV). Tópicos Transatlânticos: Emergência da Lusofonia num Mundo Plural. Évora, 2012, pp. 99-108.

BASCHET, Jérôme. Introduction: l'image-objet. In: SCHMITT, Jean-Claude et BASCHET, Jérôme. L'image. Fonctions et usages des images dans l'Occident médiéval. Paris: Le Léopard d'Or, 1996. p. 7-26.

Inventivité et sérialité des images médiévales. Pour une approche iconographique élargie. Annales: Histoire, Sciences Sociales. 1996, 51 ${ }^{\circ}$ ano, n. 1, pp. 93-133.

Paulo: Globo, 2006.

A civilização feudal: do ano mil à colonização da América. São

BAUDRILLARD, Jean; CALABRESE, Omar. El trompe-l'oeil. Madrid: Casimiro, 2014.

BELTING, Hans. Semelhança e Presença: a história da imagem antes da era da arte. Rio de Janeiro: Ars Urbe, 2010.

BESANÇON, Alain. A imagem proibida: uma história intelectual da iconoclastia. Rio de Janeiro: Bertrand Brasil, 1997.

BETHENCOURT, Francisco. Historia das inquisições: Portugal, Espanha e Itália séculos XV-XIX. São Paulo: Companhia das Letras, 2000.

BÍBLIA de Jerusalém. São Paulo: Paulus, 2011.

BREMMER, Jan N. Iconoclast, Iconoclastic, and Iconoclasm: Notes Towards a Genealogy. Church History and Religious Culture. Leiden: Brill, 2008, 88, pp. 1-17.

BONNE, Jean-Claude. L'art Roman de face et de profil: Le tympan de Conques. Paris: Le Sycomore, 1984.

- Entre ambiguité et ambivalence. Problématique de la sculpture romane. La part de l'oeil, 1992, 8, pp. 147-164. 
BRAVO LOPÉZ, Fernando. «La traición de los judíos» La pervivencia de un mito antijudío medieval en la historiografía española. Miscelanea de Estudios Arabes y Hebraicos. Granada, 2014, vol 63, pp. 27-56.

BURKART, Lucas. La Mère de Dieu est couvert de crottin de chavel. Après avoir profané l'image de Notre-Dame, Antonio di Giuseppe Rinaldeschi est pendu. in: DUPEAUX, Cécile, JEZLER, Peter e WIRTH, Jean. Cataloque de l'exposition: Iconoclasme: vie et mort de l'image médievale. Paris: Somogy, 2001.

BUSTILLO, Martha. The Episode of the Cristo de la Paciencia and Its Influence on Religious Imaginary in Seventeenth-Century Madrid. In: BUSTILLO, Martha; ROE Jeremy. Imaginary, Spirituality and Ideogy in Baroque Sapin and Latin America Newcastle upon Tyne: Cambridge Scholars Publishing. 2010, pp. 59-70.

BYNUM, Caroline. The Blood of Christ in the Later Middle Ages. Church History. Chicago, 2002, v.71, nº 4, pp. 685-715.

CANTERA MONTENEGRO, Henrique. La imagen del judío en la España Medieval. Espacio, tiempo y forma. Serie III, Historia medieval. Madrid, 1998, No 11, pp. 1138.

. El miedo al judío en la España de la Edad Media. Estudio de Historia de España. Buenos Aires, 2013, nº 13, pp 153-188.

CARO BAROJA, Julio. Inquisición, brujería y criptojudaísmo. Madrid: Arial, 1970. Los Judíos en la España Moderna y Contemporánea. Madrid: Istmo, 1978.

CARRASCO VASQUEZ, Jesus Antonio. La minoria judeoconversa en la época del Conde Duque de Olivares, auge y ocaso de Juan Núñez Saraiva (1585-1639). Tese (doutorado em História) Departamento de História da Universidade de Alcalá. Alcalá de Henares, 2004.

CARROCERA, Buenaventura de. La provincia de Frailes Menores Capuchinos de Castilla. Vol I. (1573-1701). [S.I.]: Administración de "El Mensajero Seráfico", 1949.

CHRISTIN, Olivier. Du culte chrétien au culte de l'arte : la transformation du statut de l'image (Xve-XVIIIe siècles). Revue d'histoire moderne et contemporaine. Berlin, 2002/3, n. 49-3. pp $176-194$.

CHRISTIAN, Willian A. Images as Beings in Early Modern Spain. In: KASL, Ronda. Sacred Spain: Art and Belief in the Spanish World. Indianapolis: Indianapolis Museum of Art, 2009, pp. 75-99.

CIVIL, Pierre. Image et dévotion dans l'Espagne du XVIe siècle: le traité Norte de Ydiotas de Francisco de Monzón (1563). Paris: Publications de la Sorbonne, 1996.

COELHO, Antonio Borges. Inquisição de Evora : dos primórdios a 1668. Lisboa: Caminho-Colecção Universitária, 1987. 
COMELLA, Beatriz. La Inquisição española. Madrid: Rialp, 1998.

COLLADO FERNÁNDEZ, Ángel. Historia de la Iglesia en la España. Edad Moderna. Toledo: I. T. San Idelfonso, 2007.

DAUMAS, Maurice. Images et societés dans l'Europe modern: 15e-18e sièle. Paris: Armand Colin, 2000.

DELGADO, Manuel. Exorcismo y martirio de las imágenes : la iconoclastia como violencia corporal. In : MOLINA, Pedro e CHECA, Francisco. La función simbólica de los ritos. Barcelona: Icária, 1997, pp. 367-386.

DELGADO MARTINEZ, Natalia. Fisiognomía y expresión en la literatura artística española de los siglos XVII y XVIII. Anuario del Departamento de Historia y Teoría del Arte. Murcia, 2002, v XIV, pp. 205-229.

DIDI-HUBERMAN, Georges. Diante da Imagem: questão colocada aos fins de uma história da arte. São Paulo: Editora 34, 2013.

Poderes da figura. Exegese e visualidade na Arte Cristã. Revista de Comunicação e Linguagens, Lisboa, 1994, 20, pp. 159- 177.

Gallimard, 2007.

L'image ouvert: motifs de l'incarnation das les artes visuels. Paris:

EATOUGH, Matt. Theories of Media: Keywords Glossary: iconoclasm. University of Chicago. Disponível em: http://csmt.uchicago.edu/glossary2004/iconoclasm.htm. Acesso em: 10 Jun. 2013.

ESPESO PEREDA, Felipe. El debate sobre la imagen en la España del siglo XV. Anuario del Departamento de Historia y Teoria del Arte. Madrid, 2002, vol XIV, pp. 59-79.

Las imágenes de la discordia: política y poética de la imagen sagrada en la España del cuatrocientos. Madrid: Marcial Pons, 2007. Edição Kindle.

Cultures de la representation dans l'Espagne de la Réforme Catholique.

Perspective. Paris, 2009, 2, pp. 287-300.

ESPI FORCÉN, Carlos. Érase un Hombre: a una nariz pegado. La fisiognomía del judío en la baja Edad Media. In: CONGRESO INTERNACIONAL IMAGEM Y APARENCIA. Murcia: 2008. Atas... Murcia: Universidad de Murcia, Servicio de Publicaciones, 2009.

ESPI FORCÉN, Carlos. Recrucificando a Cristo: los judíos de la Passio Imaginis en la Isla de Mallorca. Palma: Lleonard Muntaner Editor, S.L. 2009.

FERNANDEZ MOSQUERA, Santiago. Situácion e Contexto de la Execracíon de los judios de Quevedo. STUDIA AUREA: ACTAS DEL III CONGRESO DE LA AISO, Toulouse: 1993. Atas... Navarra: GRISO (Grupo de Investigación Siglo de Oro Universidad de Navarra), 1996, pp. 169-176. 
FRANCO LLOPIS, Francisco de Borja. Espiritualidade, Reformas y Arte en Valencia (1545-1609). Tese (Doutorado em História da Arte) História, Teoria i Critica de les Arts - Universidade de Barcelona, 2007.

- Noticias sobre arte y devoción del Quinientos Aragonés a través de la documentación inquisitoria. Boletín del Museo e Instituto Camón Aznar. Zaragoza, 2011, nº 107, pp. 61-76.

FREEDBERG, David. Johannes Molanus on provocative paintings. Journal of the Warburg and Courtauld Institutes. London, 1971, pp. 229-245.

Art and Iconoclasm, 1525-1580. Kunst voor de Beeldenstorm. Noordnederlandse Kunst 1525-1580. Amsterdam: Rijksmuseum, 1986, pp. 69-80.

El poder de las Imágines: estudios sobre la historia y la teoria de la respuesta. Madrid: Cátedra, 1992.

GARCIA GARCIA, Maria del Rosário. Identidad y minorías musulmanas en Colombia. Bogotá: CEPE, 2007.

GARCÍA GARRIDO, Manuela Águeda. La imagen Predicada. La virtud como camino hacía la salvacón en los retratos de Francisco Pacheco. Etiopica: Revista de Letras Renacentista. Huelva, 2006, nº 2, pp. 172-201.

GARCIA, Maria del Rosário. Identidad y minorías musulmanas en Colombia. Bogotá: CEPE, 2007.

GILA MEDINA, Lázaro. Arte e Historia del Cristo de Burgos o de Cabrilla en la Diocesis de Guadiz-Baza. Boletín del Centro de Estudios Pedro Suárez. [Guadix], 2003, pp. 23-44.

GINZBURG, Carlo. Mitos, Emblemas e Sinais: Morfologia e História. São Paulo: Companhia das Letras, 1989.

GONZÁLEZ ALONSO, Benjamin._El Conde Duque de Olivares y la administración de su tempo. In: LA ESPAÑA DEL CONDE DUQUE DE OLIVARES: ENCUENTRO INTERNACIONAL SOBRE LA ESPAÑA DEL DEL CONDE DUQUE DE OLIVARES, Toro: 1989. Anais...Valladolid: Universidad de Valladolid, 1990, pp 275314.

GONZALES GARCÍA, Juan Luis. 'Ut pictura rhetorica' Juan de Juanes y el retablo de San Esteban de Valencia. Boletín del Museo del Prado. Madrid, 1999, vol. 17, nº. 35, pp. 21-56.

GONZALEZ, J. Avance de una tipologia del retablo barroco. Imafronte. Murcia, 198789, n. 3-5, pp. 111-115.

GONZÁLEZ SALINERO, Rául. Manos manchadas de sangre: los orígenes cristianos del mito antijidío del crimen ritual. In : Collectanea Christiana Orientalia v. 10. Cordoba: Universidade de Cordoba, 2013. 
HABICHT, Peter. Des iconoclastes forcent deux saints à coucher ensembre et décapittent une statue du Christ. In: DUPEAUX, Cécile; JEZLER, Peter e WIRTH, Jean. Cataloque de l'exposition: Iconoclasme: vie et mort de l'image médievale. Paris: Somogy, 2001.

HEIPLE, Daniel L. Heiple. Political Posturing on the Jewish Question by Lope de Vega and Faria e Sousa. Hispanic Review, [S.I.], 1994, vol. 62, nº 2, pp. 217-234.

HERNANDEZ SOTELO, Anel. ¿Quiénes son los capuchinos? Aportación historiográfica sobre los orígenes de una reforma franciscana. GRAFFYLIA. Cidade do México, 2009, ano 6, nº 10, pp.117-132.

JEZLER, Peter. La Reforme et la question des images. In: DUPEAUX, Cécile; JEZLER, Peter e WIRTH, Jean. Cataloque de l'exposition: Iconoclasme: vie et mort de l'image médievale. Paris: Somogy, 2001.

LE BRUN, Charles. Méthode pour apprende à dessiner les passions. Amsterdam: Hildesheim: G. Olms, 1702. Post-mortem.

LICHTENSTEIN, Jacqueline. A pintura: textos essenciais. Vol. 2: A teologia da imagem e o estauto da pintura. São Paulo: 34, 2008.

LUBARINO, Doglas Morais. O Juizo Final e a Missa de São Gregório (MASP 428P): pintura retabular Eucaristica no final da Idade Média. Dissertação (Mestrado em História Social) - FFLCH - Departamento de História. UPS. São Paulo 2015 .

LUNA MORENO, Luis. Sangre de Cristo y Cristo de la Sangre. Planteamientos iconográficos en España y Europa. In: MOYA MARTÍNEZ, Jose Juan. Vid Salvífica. actas de las VI Jornadas Nacionales de Contrarias Medievales de la Sangre de Cristo. Calasparra: Antigua y Venerable Cofradía de la Sangre de Cristo y la Vera Cruz de Calasparra, 2010, pp. 257-276.

LUPI, João Eduardo Pinto Basto. Iconoclastas, Antieréticos e o Poder da Imagem. Ágora Filosófica. Recife, 2001, pp. 149-167.

MAIMONIDES, Mose. Guia de los Descarriados y Perplejos - Maiomonides. Org: VALERA, Fernando. México: Oríon, 1947.

MARQUEZ, Francisco. Estudio preliminar. In: TALAVERA, Frey Hernando de, Católica Impugnación. Barcelona: Juan Flores, 1961, pp. 5-58.

MARTENS, Didier. Iconoclasmes et malentendus. Une image méconnue du Sacrilège de Cambron. Zeitschrift für Kunstgeschichte. Berlin, 2007, pp. 215-236.

MARTÍN, Manuel Urí. Banqueros Portugueses em Castilla: acerca de um texto antimarrano de Quevedo. In: ACTAS XIII CONGRESO ASOCIACIÓN INTERNACIONAL HISPANISTAS (Tomo I). Madrid, 1998, Atas... Madrid: Castalia, 2000. 
MARTINEZ-BURGOS GARCIA, Palma. Ídolos e Imágenes: la controvérsia del arte religioso en el siglo XVI español. Valladolid: Universidad Valladolid/Caja Salamanca, 1990.

MARTÍNEZ MARTÍNEZ, Maria José. El Santo Cristo de Burgos. Contribución al estudio de los Crucifijos articulados españoles. Boletín del Seminario de Estudíos de Arte y Arquiología, BSAA. Valladolid, 2003-2004, tomo 69-70, pp. 207-246.

MARTINEZ MILLAM, José. La Inquisición española. Madrid: Alianza, 2007.

MARTINS, Fausto Sanches. As imagens das Nossas Igrejas. In: Actas I CONGRESSO SOBRE A DIOCESE DO PORTO: TEMPOS E LUGARES DE MEMÓRIA. Porto: 1998. Atas... Porto: Centro de Estudos D. Domingos de Pinho Brandão, 2002, pp. 211221.

O conceito de "Nihil Inhonestum" nos Tratados Artísticos Póstridentinos. In: Estudos em homenagem a Luiz António de Oliveira Ramos. Porto: Universidade do Porto, 2004, pp. 715-726.

MEA, Elvira Cunha de Azevedo Silva. Nossa Senhora em processos da Inquisição. Revista da Faculdade de Letras: História. Porto, 1984, vol, 1, pp. 135-158.

MENDES, Antônio Rosa. A vida Cultural. In: MAGALHÃES, Joaquim Romero (coord.). História de Portugal no alvorecer da modernidade. Vol. 3. Coimbra: Estampa, 1993.

MOLINA FIGUERAS, Joan. Las imágenes del judío en la españa medieval. In: Memoria de Sefarad. Madrid: Sociedad Estatal, 2002.

La Imagen y su contexto. Perfiles de la Iconografía antijudaíca en la España Medieval. In: Els jueus a la Girona medieval. Girona: Bell-1loc, 2007, pp. 3385.

MORENO MARTINEZ, Doris. Ciros, trompetas y altares. El auto de fe como fiesta. Espacio, tiempo y forma. Barcelona, 1997, t. 10, pp. 143-171.

MUSEO DEL PRADO. Inventario general de pinturas II. EI Museo de la Trinidad, Madrid: Espasa Calpe, 1991.

$12 / 2015$.

Coleccion: www.museodelprado.es/coleccion/obra-de-arte. Acesso em

NAVARRO ESPINACH, Germán. Las cofradías de la Vera Cruz y de la Sangre de Cristo en la Corona de Aragón. Anuario de estudios Medievales. Barcelona, 2006, $\mathrm{n}^{\mathbf{o}}$ 36, pp 583-661.

O’MALLEY, John. Art, Tren and Michelangelo's 'last judgment'. Religions, 2012, 3, pp. 344-356. Open Access: www.mdpi.com/2077-1444/3/2/344/pdf. Assesso em: $07 / 10 / 2015$

PAOLINI, Devid. El gesto obsceno 'dar las higas' en la Celestina. Celestinesca. Valencia, 2000, nº 33, pp. 127-141. 
PASTOUREAU, Michel. Formes et couleurs dú desordre: le jaune avec le vert.

Médiévales, 1983, nº4, pp. 62-73.

PEDRERO-SÁNCHEZ, Maria Guadalupe. Os judeus na Espanha. São Paulo: Editora Giordano, 1994.

PÉREZ GONZÁLEZ, Silvia Maria, SÁNCHEZ HERRERO, José. La cofradía de la sangre de Cristo Sevilla: La importancia de la devoción a la preciosa sangre de Cristo en el desarrollo de la devoción y la imaginería de la Semana Santa. Aragón en la Edad Media. Zaragoza, 1999, nº14-15, pp. 1429-1452.

PÉREZ SÁNCHEZ, Alfonso E. Pintura Barroca en Enspaña : 1600-1750. Madrid: Manuales Arte Cátedra, 2010.

PRODI, Paolo. Uma história da justiça do pluralismo dos foros ao dualismo moderno entre consciência e direito. São Paulo: Martins Fontes. 2005.

PULIDO SERRANO, Juan Ignacio. Injúrias a Cristo: religión, política y antjudaísmo en el siglo XVII, Alcalá de Henares: Instituo Internacional de Estudios Sefardíes y Andalusíes - Universidad de Alcalá, 2002.

RÉAU, Louis. L'art Chrétien. Tome III: Iconographie des Saints P-Z. Paris: PUF, 1959. pp. 1226-1227.

RIBEIRO, Benair Alcaraz Fernades. Arte e Inquisição na Península Ibérica. Tese (Doutorado em História Social) - FFLCH - Departamento de História. UPS. São Paulo 2006.

RICO CALLADO, Francisco Luis. La imitatio Christi y los itinerarios de los religiosos: hagiografía y prácticas espirituales en la vocación religiosa en la España moderna. Hispania Sacra. Madrid, 2013, vol 65, nº extra 1, pp.127-152.

RODRIGUEZ BARRAL, Paulino. Eucaristía y antisemitismo en la plástica gótica hispánica. Boletín del Museo e Instituto Camón Aznar. Zaragoza, 2006, no 97 , pp. 279-348.

La acusación de crimen ritual: una aproximación a su iconografía a partir del caso del "Santo Niño de La Guardia". El Olivo. Madrid, 2006, 63, pp. 65-100.

El recurso al judío deicida: un punto de encuentro entre el drama y las artes visuales en la Valencia de la edad media final. Estudios sobre teatro medieval. Valencia, 2008, pp. 157-174.

La imagen del judío en la España medieval: el conflicto entre cristianismo y judaísmo en las artes visuales góticas. Barcelona: Memoriua Artium, 2008 .

RODRIGUEZ G. DE CEBALlOS, Alfonso. "Trampantojos a lo divino": iconos pintados de cristo y de la virgen a partir de imágenes de culto en América meridional. In: III CONGRESO INTERNACIONAL DEL BARROCO AMERICANO. Sevilla: 
2001. Atas... Sevilla: Territorio, Arte, Espacio y Sociedad: Universidad Pablo de Olavide, 2001.

El Cristo Crucificado de Velásquez. Revista Archivo Español de Arte, 2004, 305, pp. 5-19.

SÁEZ, Adrián J. Los Cuatrocientos milagros de la Cruz: ¿Libro de cabecera de Calderón?. Atalanta: Revista de las Letras Barrocas. Sevilla, 2013, v.1, no.1, pp 103118.

SALTEIRO, I. Do retábulo, ainda: aos novos modos de fazer e pensar. 2005. Tese (Doutorado em Belas artes) - Faculdade de Belas Artes, Universidade de Lisboa. Lisboa, 2005.

SÁNCHEZ MILLÁN, Rafael. Arbol, vid y leño de la tentacíon: Cristo crucificado y el protagonismo de la cruz. IMAGO: Revista de Emblemática y Cultura Visual. Valencia, 2011, no 3, pp.7-24.

SÁNCHEZ RIVERA, Jesús Ángel. Mateo Cerezo “el Joven” y su padre en el convento santiaguista de Madrid: nuevas pinturas e hipótesis sobre su presencia. In: XIX SIMPOSIOIM SAN LORENZO DEL ESCORIAL: LA CLAUSURA FEMININA EN EL MUNDO HISPÁNICO. Escorial: 2011. Simposium... Escorial: Instituto Escurialense de Investigaciones Históricas y Artísticas, 2011, pp. 1026-1046.

SANSTERRE, Jean-Marie. La imagen activada por su prototipo celestial: milagros occidentales anteriores a mediados del siglo XIII. Codex Aqvilarensi, 29: Imágenes en acción. Actos y actuaciones de las Imágenes en la Edad Media. Palencia, 2013, pp. 77-98.

SARAIVA, António José. Inquisição e Cristãos-novos. Lisboa: Estampa, 1994.

SCHMITT, Jean-Claude. O corpo das imagens. Ensaios sobre a cultura visual na Idade Média. São Paulo: Edusc, 2007.

Verbete: Imagem, in: LE GOFF, Jacques e SCHMITT, Jean-Claude (org). Dicionário temático do Ocidente Medieval. São Paulo: Edusc, 2006, v. 1.

SCHOLZ-HÄNSEL, Michael. Arte e Inquisición: Pedro Arbués y el poder de las imágenes. Anuario del Departamento de Historia y Teoría del Arte. Madrid, 1994, no 6, pp. 205-212.

Inquisition und Kunst: Convivencia in Zeiten der Intoleranz. Berlin: Frank \& Timme, 2009.

SERRÃO, Vitor, Impactos do Concílio de Trento na Arte Portuguesa entre o Maneirismo e o Barroco (1563-1750). In: GOUVEIA, António Camões; BARBOSA, David Sampaio Barbosa; PAIVA, José Pedro. O Concílio de Trento em Portugal e nas suas Conquistas: olhares novos. Lisboa: UCP, 2014, pp. 103-132.

A pintura maneirista e proto-barroca. In: RODRIGUES, Dalila (org.). Arte Portuguesa da pré-história ao século XX. Lisboa: Fubu Editores, 2009, v.11. 
Pintura e Propaganda em Évora nos alvores do século XVII: um panfleto contra a iconoclastia e dois casos de repressão. In: BARRETO, Luís Filipe. Inquisição portuguesa: tempo razão e circunstancia. Lisboa: Prefácio, 2007, pp. 423-446.

Entre a Maneira Moderna e a Idéia de decoro. In: PAULINO, Francisco Faria. A pintura maneirista em Portugal: arte no tempo de Camões. Lisboa: CNCDP, 1995, pp. 16-57.

SIERRA, Julio. Procesos de la Inquisicion en Toledo (1575-1610): Manuscrito de Halle. Madrid: Trotta, 2005.

SKINNER, Quentin. As fundações do pensamento político moderno. São Paulo: Companhia das Letras, 2009.

STOICHITA, Victor I. El ojo místico. Pintura y vision religiosa en el Siglo de Oro español. Madrid: Alianza, 1996.

modernes. Genève: Droz, 1999.

L'instauration du tableau. Métapeinture à l'aube des tempes

SUÁREZ QUEVEDO, Diego. De imagen y reliquia sacras. Su regulación en las constituciones sinodales postridentinas del arzobispado de Toledo. Anales de Historia del Arte. Madrid, 1998, vol 8, pp. 257-290.

TEIXEIRA, Alfredo. Uma politica da imagem: leitura antropológica da blasfémia visual de Pierre Legendre. Revista Portuguesa de História, Coimbra, 2008, pp. 143-174.

TORRES JIMENEZ, Raquel. Notas para una reflexión sobre el cristocentrismo y la devoción medieval de la Pasión y para su estudio en el medio rural castellano. In: Hispania Sacra. Madrid, 2006, v.58, 118, pp. 449-487.

VARAZZE, Jacopo de. Legenda Aurea: vida de santos. São Paulo: Companhia das Letras, 2003.

VAUCHEZ, André. Du culte des reliques à celui du Précieux Sang. Tabularia «Études». Caen, 2008, n 8, pp. 81-88.

VELANDIA ONOFRE, Darío. Hacia una teología de la imagen. Mística, oratória y pintura en la España del Siglo de Oro. Tese (Doutorado em História da Arte) Universidade de Barcelona, Barcelona, 2014.

VILLANUEVA CUEVA, Carmen. El Crucificado, en la vida y escritos de Santo Tomás de Villanueva. SIMPOSIOIM LOS CRUCIFICADOS, RELIGIOSIDAD, CONFRADÍAS Y ARTE, Escorial: 2010. Atas... Escorial: Instituto Escurialense de Investigaciones Históricas y Artísticas, 2010, pp. 21-44.

WIRTH, Jean. Faut-il adorer les images? La théorie du culte des images jusqu'au concile de Trente. in: DUPEAUX, Cécile; JEZLER, Peter e WIRTH, Jean. Cataloque de l'exposition: Iconoclasme: vie et mort de l'image médievale. Paris: Somogy, 2001. 
Pour les catholiques, l'acte iconoclaste est un attent sacrilege contre la persona de Dieu, de la Vierge ou des saints. in: DUPEAUX, Cécile; JEZLER, Peter e WIRTH, Jean. Cataloque de l'exposition: Iconoclasme: vie et mort de l'image médievale. Paris: Somogy, 2001.

L'iconoclasme après la Réforme. in: DUPEAUX, Cécile; JEZLER, Peter e WIRTH, Jean. Cataloque de l'exposition: Iconoclasme: vie et mort de l’image médievale. Paris: Somogy, 2001.

\section{4. Índice de Figuras}

Figura 1 - Martirio del brasero del Cristo de la Paciencia, 1647-1651, óleo sobre tela, 171 com x $296 \mathrm{~cm}$, Andrés de Vargas.

Figura 2 - Ultrajes al crucifijo o Cristo de las injurias, 1647-1651, óleo sobre tela, 210 cm x $231 \mathrm{~cm}$, Francisco Camilo, Museu do Prado, depositado na Biblioteca-Museu Víctor Balaguer em Villanueva y Geltrú.

Figura 3 - Sacrilegio de unos judios: judios arrastando y azotan el crucifij, 1647-1651, óleo sobre tela, 171 x 296 cm, Francisco Fernadez, Museu do Prado [P03873]

Figura 4 - Profanación de un crucifijo (Familia de herejes azotando un crucifijo), 16471651, óleo sobre tela, 207 cm x 230 cm, Francisco Rizi, Museu do Prado [P03775]...... 13

Figura 5 - Iglesia y Convento Capuchinos de la Paciencia, 15,5 cm x 22,3 cm, litografia, c. 1863, Biblioteca Nacional da Espanha [45981]

Figura 6 - La Santa Faz, c. 1631, óleo sobre tela, 70 cm x 51,5 cm, Francisco Zurbarán, Museu de Belas Artes da Suécia [NM 5382].

Figura 7 - Cristo de Medinaceli arrastrado por las calles de Mequinez, óleo sobre tela, 25 cm x 30 cm, 1681; Juan de Valdés Leal, Fundação Casa Ducal de Medinaceli. ...... 53

Figura 8 - Iglesia y Convento Capuchinos de la Paciencia, 15,5 cm x 22,3 cm, litografia, c. 1863, Biblioteca Nacional da Espanha [45981]. 
Figura 10 - Vista da Igreja e Convento dos Capuchinhos da Paciência de Madri, Detalhe: Madrid Ciudad Regia, gravura, 1659, Pedro Teixeira Albernaz, fl. 9r.

Figura 11 - Auto de Fe en la Plaza Mayor de Madrid, 1683, óleo sobre tela, $277 \mathrm{~cm} \mathrm{x}$ 438 cm, Francisco Rizo, Museo do Prado [P01126].

Figura 12 - Expolio de Cristo, 1651, óleo sobre tela, $527 \mathrm{~cm} \mathrm{x} 352 \mathrm{~cm}$, Francisco Rizi, Museu do Prado, depositado na Catedral de Almudena [P02925]

Figura 13 - frontispício Vespertinas de los opróbios de la Passion de Cristo, 1634, gravura, 17,5 cm x $12 \mathrm{~cm}$, Jean de Coubers, Biblioteca Nacional da Espanha [R-14461].

Figura 14 - Ultrajes al crucifijo o Cristo de las injurias, 1647-1651, óleo sobre tela, 210 cm x $231 \mathrm{~cm}$, Francisco Camilo, Museu do Prado, depositado na Biblioteca-Museu Víctor Balaguer em Villanueva y Geltrú. 94

Figura 15 - Profanación de un crucifijo (Familia de herejes azotando un crucifijo), 16471651, óleo sobre tela, 207 cm x 230 cm, Francisco Rizi, Museu do Prado [P03775]...... 97

Figura 16 - Sacrilegio de unos judios: judios arrastando y azotan el crucifij, 1647-1651, óleo sobre tela, 171 x 296 cm, Francisco Fernadez, Museu do Prado [P03873] 100

Figura 17 - Martirio del brasero del Cristo de la Paciencia, 1647-1651, óleo sobre tela, 171 com x $296 \mathrm{~cm}$, Andrés de Vargas. 103

Figura 18 - Ultrajes al crucifijo o Cristo de las injurias, 1647-1651, óleo sobre tela, 210 cm x $231 \mathrm{~cm}$, Francisco Camilo, Museu do Prado, depositado na Biblioteca-Museu Víctor Balaguer em Villanueva y Geltrú.

Figura 19 - Detalhe: Ultrajes al crucifijo o Cristo de las injurias (Figura 19) 110

Figura 20 - Sacrilegio de unos judios: judios arrastando y azotan el crucifijo, 16471651, óleo sobre tela, 171 x 296 cm, Francisco Fernadez, Museu do Prado [P03873].111

Figura 21 - Detalhe: Sacrilegio de unos judios: judios arrastando y azotan el crucifijo (Figura 20) 
Figura 22 - Profanación de un crucifijo (Familia de herejes azotando un crucifijo), 16471651, óleo sobre tela, $207 \mathrm{~cm}$ x 230 cm, Francisco Rizi, Museu do Prado [P03775].... 113

Figura 23 - Detalhe da Figura 22

Figura 24 - Detalhe da Figura 22

Figura 25 - Detalhe da Figura 22

Figura 26 - Martirio del brasero del Cristo de la Paciencia, 1647-1651, óleo sobre tela, 171 com x $296 \mathrm{~cm}$, Andrés de Vargas. 116

Figura 27 - Detalhe da Figura 26

Figura 28 - Detalhe Cantigas de Santa Maria (Códice Rico) T. Ms.T-I-1, RBME, fl. $20 \mathrm{v}$.

Figura 29 - Ecce Homo, 1520-1525, óleo sobre madeira, 109 cm x 167 cm, Mestre de La Santa Sangre, Museu do Prado [P01559]....

Figura 30 - Santa Cena, c. 1622, Vicente Carducho, Convento las Carboneras de Madri

Figura 31- Martirio de San Bartolomé, século XVII, óleo sobre tela, 79,5 cm x $100 \mathrm{~cm}$, Museo de Huesca [00100].

Figura 32 - Cenas do Retablo de San Esteban, 1562, óleo sobre madeira, Juan de Juanes, Museu do Prado [P00839-840-841-842].

Figura 33 - Retabulo Passio Imaginis, sec. XV, relevo em arenito, Igreja de São Miguel em Felanitx. 125

Figura 34 - Detalhe da Figura 33. 125

Figura 35 - Santa Cena, c.1606, óleo sobre tela, Francisco Ribalta, Colegio del Patriarca de Valencia. 126

Figura 36 - Martírio de San Pedro Arbués, c. 1664, óleo sobre tela, 94,2 cm x 60 cm, Bartolomé Esteban Murillo, Museu do Hermitage de São Petersburgo [nº inv. 448].. 127 
Figura 37 - Martírio de San Bartolomé, óleo sobre tela, $249 \mathrm{~cm}$ x $205 \mathrm{~cm}$, Francisco

Camilo, Museu do Prado [P00623].

Figura 38 - Sambenito, sec. XVII, Museu da Diocese de Tuy.

Figura 39 - Detalhe do Auto de Fe presidido por Santo Domingo de Guzmán, 14931499, óleo sobre madeira, $154 \mathrm{~cm}$ x $92 \mathrm{~cm}$, Pedro Berruguete, Museu do Prado [P00618].

Figura 40 - La coronación de espiñas y los escarnios, séc. XVI, óleo sobre madera, 9,3 cm x 14,7 cm Museu Lázaro Galdiano [02769]

Figura 41 - Cristo Conducido a la flagelación, segunda metade do século XVII, óleo sobre tela, $183 \mathrm{~cm}$ x 134cm, Museo de Bellas Artes de Córdoba [CE2234P].

Figura 42 - Coronación de espinas, 1631, óleos sobre tela, $221 \mathrm{~cm}$ x $120 \mathrm{~cm}$, Francisco Pacheco, Museo de Bellas Artes de Sevilla [CE0075P].

Figura 43 - Flagelación de Cristo, segunda metade XVII, óleos sobre tela, $201 \mathrm{~cm} \mathrm{x}$ $162 \mathrm{~cm}$, Fray Juan del Santísimo Sacramento, Museo de Bellas Artes de Córdoba [CE2117P].

Figura 44 - Ecce Homo, 1626-1627, óleos sobre tela, 278 cm x $200 \mathrm{~cm}$, Fray Juan

Sánchez Cotán, Museo de Bellas Artes de Granada [CE0122].

Figura 45 - Cristo con la Cruz a Cuesta, 1626-1627, óleo sobre tela, $278 \mathrm{~cm}$ x $201 \mathrm{~cm}$, Fray Juan Sánchez Cotán, Museo de Bellas Artes de Granada [CE0123].

Figura 46 - Detalhes das Figuras 1, 2 e 3

Figura 47 - Cristo de Burgos, Catedral de Santa Maria de Burgos: capela do Santíssimo Cristo de Burgos.

Figura 48 - Santíssimo Cristo de Burgos, séc. XVII, óleo sobre tela, Jacinto Aguiano Ibarra - Santuário de Cabra do Santo Cristo de Jaen.....

Figura 49 - Santíssimo Cristo de Burgos, sec. XVII, óleo sobre tela, Mateo Cerezo el viejo, Monastério de São Joaquim e Santa Ana de Valladoli. 
Figura 50 - San Pedro Celestino, papa, sec. XVII, óleo sobre tela, $208 \mathrm{~cm}$ x $110 \mathrm{~cm}$, Bartolomé Román, Museu do Prado [P03346]....

Figura 51 - San Jerónimo c. 1650, óleo sobre tela, 187 cm x 133 cm, Bartolomé Esteban Murillo, Museu do Prado [P00987]. 148

Figura 52 - La venerable madre Jerónima de la Fuente, 1620, óleo sobre tela, $160 \mathrm{~cm} \mathrm{x}$ 110 cm, Diego Rodríguez de Silva y Velásquez, Museu do Prado [P02873].

Figura 53 - Cena dos iconoclastas contra a adoração dos reis magos, sec. XVI, óleo sobre madeira, Museu da Chartreuse [ $\mathrm{n}^{\mathrm{o}}$ do inventário: 1598].

Figura 54 - El milagro del Cristo del rescate, c. 1623, óleo sobre tela, $243 \mathrm{~cm} \mathrm{x} 168 \mathrm{~cm}$, Jerónimo Jacinto Espinosa, Coleção Privada, Valencia.

Figura 55 - San Domingo en Soriano, c. 1655, óleo sobre tela, $470 \mathrm{~cm}$ x $310 \mathrm{~cm}$, Antonio de Pereda, Museu Cerralbo [00056].

Figura 56 - San Juan Evangelista y la virgen coronan a San Juan de Dios, 1650, óleo sobre tela, Francisco Camilo, The Bowes Museum, Durham.

Figura 57 - San Bernardo y la Virgen, 1649-1652, óleo sobre tela, $267 \mathrm{~cm}$ x $185 \mathrm{~cm}$, Alonso Cano, Museu do Prado [P03134].

Figura 58 - Sacrilegio de unos judios: judios arrastando y azotan el crucifij, 1647-1651, óleo sobre tela, 171 x 296 cm, Francisco Fernadez, Museu do Prado [P03873]. 155

Figura 59 - Detalhe da Figura 58 156

Figura 60 - Retábulo da Vida de São Tomas de Aquino, Igreja do real monastério de São Tomas de Avila.

Figura 61 - Detalhe da Figura 60

Figura 62 - San Pedro Mártir en oración, sec. XV, óleo sobre madera, $133 \mathrm{~cm}$ x $86 \mathrm{~cm}$, Pedro Berruguete, Museu do Prado [P00612]. 160

Figura 63 - San Tomas de Villanueva y el crucifijo, 1664-1670, óleo sobre tela, $130 \mathrm{~cm}$ x 75 cm, Bartolomé Esteban Murillo, Museo de Bellas Artes de Sevilla [CE0126P]. 161 
Figura 64 - El milagro de Segovia. Aparición de Jesús de Nazareno, 1625, óloeo sobre tela, Francisco Martínez, Santuário da Virgem do Carmo, em Medina do Campo...... 162

Figura 65 - São João da Cruz, c. 1673, óleo sobre tela, Josefa de Óbidos, Santa Casa da Misericórdia de Figueiró dos Vinhos.

Figura 66 - Profanación de un crucifijo (Familia de herejes azotando un crucifijo), 16471651, óleo sobre tela, $207 \mathrm{~cm}$ x 230 cm, Francisco Rizi, Museu do Prado [P03775].... 164

Figura 67 - Nossa Senhora do Carmo e São Simão Stock combatendo a iconoclastia, 1620-1625, óleo sobre madeira, Igreja Nossa Senhora do Carmo de Évora.

Figura 68 Detalhe da Figura 67.

Figura 69 - Retablo de la capilla Passio Imaginis, catedral de Valencia en la obra de Juan Bautista Ballester, Identidad de la imagen del S. Christo de S. Salvador de Valencia. Valencia, Gerónimo Vilagrasa, 1672, pp. 454-455, Biblioteca Nacional, Madrid.

Figura 70 - Detalhe da Figura 69 170

Figura 71- Detalhe da Figura 66.

Figura 72 - Detalhe da Figura 66

Figura 73 - La Flagelación de Jesús, c. 1700, óleo sobre tela, $38 \mathrm{~cm} \mathrm{x} 48 \mathrm{~cm}$, Museo de Huesca [00116]

Figura 74 - Flagelación del Señor, c. 1670, óleo sobre tela, 336 cm x 226 cm, Juan de Sevilla Romero, Museo de Bellas Artes de Granada [CE0166].

Figura 75 - Retábulo de Vallbona de les Monges de Urgel, 108,8 cm x $222 \mathrm{~cm}$, Museu de Arte Nacional da Catalunha [009920-000] 175

Figura 76 Detalhe da Figura 75. 176

Figura 77 - Retábulo à Virgen, Museu de Arte Nacional da Catalunha [015916-CJT].

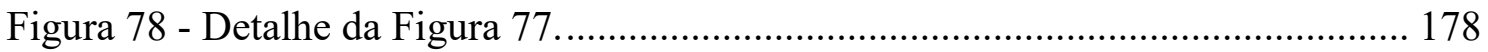


